San Jose State University

SJSU ScholarWorks

Master's Theses

Master's Theses and Graduate Research

1994

\title{
The Huntington Library's early nineteenth-century sheet music and its publishers
}

Albert R. Rice

San Jose State University

Follow this and additional works at: https://scholarworks.sjsu.edu/etd_theses

\section{Recommended Citation}

Rice, Albert R., "The Huntington Library's early nineteenth-century sheet music and its publishers" (1994). Master's Theses. 795.

DOI: https://doi.org/10.31979/etd.jztn-c78r

https://scholarworks.sjsu.edu/etd_theses/795

This Thesis is brought to you for free and open access by the Master's Theses and Graduate Research at SJSU ScholarWorks. It has been accepted for inclusion in Master's Theses by an authorized administrator of SJSU ScholarWorks. For more information, please contact scholarworks@sjsu.edu. 


\section{INFORMATION TO USERS}

This manuscript has been reproduced from the microfilm master. UMI films the text directly from the original or copy submitted. Thus, some thesis and dissertation copies are in typewriter face, while others may be from any type of computer printer.

The quality of this reproduction is dependent upon the quality of the copy submitted. Broken or indistinct print, colored or poor quality illustrations and photographs, print bleedthrough, substandard margins, and improper alignment can adversely affect reproduction.

In the unlikely event that the author did not send UMI a complete manuscript and there are missing pages, these will be noted. Also, if unauthorized copyright material had to be removed, a note will indicate the deletion.

Oversize materials (e.g., maps, drawings, charts) are reproduced by sectioning the original, beginning at the upper left-hand corner and continuing from left to right in equal sections with small overlaps. Each original is also photographed in one exposure and is included in reduced form at the back of the book.

Photographs included in the original manuscript have been reproduced xerographicaliy in this copy. Higher quality $6 "$ " 9 9" black and white photographic prints are available for any photographs or illustrations appearing in this copy for an additional charge. Contact UMI directly to order.

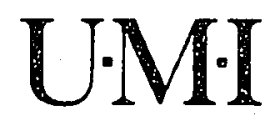

University Microfilms International

A Bell \& Howell Information Company

300 North Zeeb Road. Ann Arbor. MI 48106-1346 USA

$313 / 761-4700 \quad 800 / 521-0600$ 
Order Number 1358219

The Huntington Library's early nineteenth-century sheet music and its publishers

Rice, Albert Richard, M.L.S.

San Jose State University, 1994

Copyright (C1994 by Rice, Albert Richard. All rights reserved.

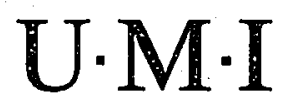

300 N. Zeeb Rd.

Ann Arbor, MI 48106 


\title{
THE HUNTINGTON LIBRARY'S EARLY NINETEENTH-CENTURY SHEET MUSIC AND ITS PUBLISHERS
}

\author{
A Thesis \\ Presented to \\ The Faculty of the School of Library \& Information Science \\ San Jose State University \\ In Partial Fulfillment \\ of the Requirements for the Degree \\ Master of Library Science
}

by
Albert R. Rice

May, 1994 


\section{Copyright 1994}

Albert R. Rice

All Rights Reserved 
APPROVED FOR THE SCHOOL OF LIBRARY \& INFORMATION SCIENCES
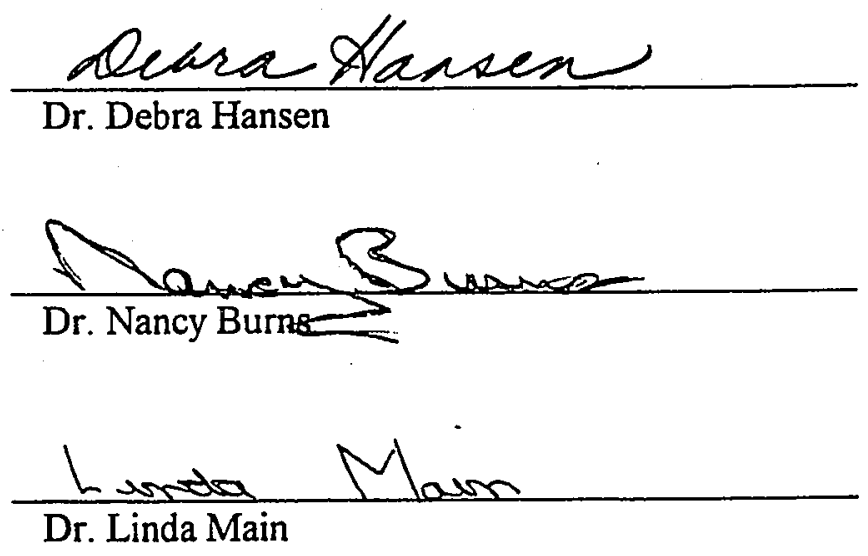

APPROVED FOR THE UNIVERSITY

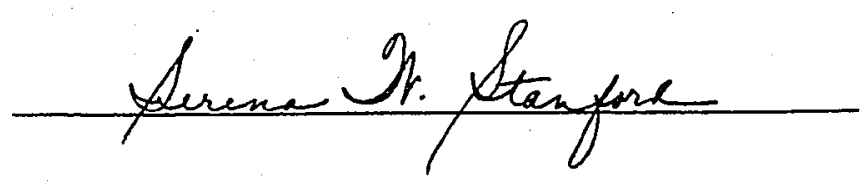




\begin{abstract}
THE HUNTINGTON LIBRARY'S EARLY NINETEENTH CENTURY SHEET MUSIC AND ITS PUBLISHERS
\end{abstract}

by Albert R. Rice

This thesis contains a listing of the American sheet music published from 1796 to 1830 preserved in the Henry E. Huntington Library. It examines music publishers represented in the collection, especially those that also made and sold musical instruments.

The Huntington's comprehensive collection includes examples of early American sheet music from all of the major and many smaller publishers in New York, Philadelphia, Boston, and Baltimore. The contributions and importance of these publishers are detailed and placed in an historical context. Research into the publishers' activities indicates that a number also made and sold musical instruments. This study provides an introduction to American popular music from 1630 to 1830 ; a history of the music trades from 1716 to 1830; a discussion of twelve music publishers and their activities; and a discussion of five aspects of sheet music in the Huntington Library. 


\section{ACKNOWLEDGEMENTS}

I would like to thank Allen Jutzi, rare book curator at the Huntington Library, for his generousity and helpfulness in guiding me to the sheet music holdings of this Library during the summer of 1993. Jill Cogan of the Huntington Library also provided interest and support during this project. Many thanks go to Dr. Debra Hansen who exhibited an uncommon interest and enthusiasm in the project and provided important editorial advice. Thanks also go to Dr. Nancy Burns and Dr. Linda Main, members of my committee, for their support and suggestions. Lastly, my wife Eleanor provided expert editing and loving support throughout the entire process. 


\section{PREFACE}

This thesis originated during my internship at the Huntington Library (San Marino, California) from September to December 1993 where I examined its cataloged and uncataloged American sheet music dating from 1793 to 1830 . The result was a reference list of 551 musical works indexed by title, composer, publisher, and performance media. By using several reference sources, I was able to redate the majority of these works and, in several cases, further identify their composers.

Music publishers during the eighteenth and nineteenth centuries were engaged in a number of activities in order to make a livelihood. These activities are more fully documented here than in previous studies. An important activity of many music publishers was the manufacturing and/or selling of musical instruments. This study includes a detailed discussion and new information concerning publishers who were involved in this activity.

The thesis begins with a chapter on the history of American popular music and the publication of sheet music during the eighteenth and nineteenth centuries. The second chapter discusses the literature of the subject. Chapter three is a history of the music trades from 1716 to 1830; chapter four discusses five aspects of American sheet music as illustrated by music from the Huntington Library's collection. An appendix chronologically lists the sheet music in the Huntington Library to 1830 . Indices of the appendix include music titles; composers; publishers, listed by city; and performance media. 


\section{TABLE OF CONTENTS}

Acknowledgements iv

Preface v v

Table of Contents vi

Chapter One: American Popular Music and Sheet Music, 1630 to 1830

Introduction 1

Popular or Secular Music $\quad 2$

The Introduction of Sheet Music 5

The Physical Nature of Sheet Music $\quad 7$

Genres of Popular Music $\quad 8$

Performing Media 9

$\begin{array}{ll}\text { Conclusion } & 10\end{array}$

Chapter Two: Literature Review

$\begin{array}{ll}\text { Introduction } & 13\end{array}$

$\begin{array}{ll}\text { Primary Sources } & 13\end{array}$

$\begin{array}{ll}\text { Secondary Sources: Listings and Directories of Publishers } & 14\end{array}$

Studies on the History and Development of Music Publishing and

$\begin{array}{ll}\text { Printing } & 16\end{array}$

Studies of Music Printing, Publishing, and Instrument Making in Boston and New York 18

Musical Instruments and Musical Instrument Makers 20

$\begin{array}{ll}\text { Conclusion } & 22\end{array}$

Chapter Three: Music Trades, 1716 to 1830

Introduction 26

Music and Instrument Dealers, 1716-1807 26

Publishers as Dealers and Makers of Musical Instruments, 1793-1830 30

Hewitt 32

Von Hagen $\quad 33$

Graupner $\quad 35$

$\begin{array}{ll}\text { Blake } & 37\end{array}$

$\begin{array}{ll}\text { Geib } & 38\end{array}$

Riley $\quad 40$

Dubois $\quad v i \quad 41$ 
Bacon $\quad 42$

$\begin{array}{ll}\text { Parker } & 43\end{array}$

Klemm 44

Firth, Hall \& Pond $\quad 45$

Ashton $\quad 46$

$\begin{array}{ll}\text { Conclusion } & 48\end{array}$

Chapter Four: Some Aspects of Sheet Music in the Collection of the Huntington Library

Introduction $\quad 56$

$\begin{array}{ll}\text { Title Pages } & 57\end{array}$

Illustrations $\quad 59$

Optional Melodic Instruments $\quad 62$

Additional Instruments $\quad 66$

$\begin{array}{ll}\text { Metronomic Indications } & 68\end{array}$

$\begin{array}{ll}\text { Conclusion } & 69\end{array}$

$\begin{array}{ll}\text { Epilogue } & 72\end{array}$

$\begin{array}{ll}\text { Examples } & 76\end{array}$

Appendix: A List of American Sheet Music at the Huntington Library Dating from 1793 to $1830 \quad 91$

$\begin{array}{ll}\text { Index of Titles } & 166\end{array}$

$\begin{array}{ll}\text { Index of Composers and Arrangers } & 178\end{array}$

$\begin{array}{ll}\text { Index of Publishers by City } & 184\end{array}$

$\begin{array}{ll}\text { Index of Performance Media } & 187\end{array}$

$\begin{array}{lr}\text { Bibliography } & 189\end{array}$ 


\section{CHAPTER ONE \\ AMERICAN POPULAR MUSIC AND SHEET MUSIC, 1630 TO 1830}

\section{Introduction}

Music publishing in the United States began with the ninth edition of the Bay Psalm Book printed in 1698 by B. Green and J. Allen for Michael Perry in Boston. This included an eight-page hymn tune supplement which was printed using woodcuts. The majority of music published in colonial America was sacred in character, consisting of hymns assembled in tunebooks. These hymns were adaptations of biblical psalms in verse, often designed for singing to simple, popular tunes.

By the 1720 s, woodcuts were replaced by freehand music engraving which was used for the many collections of sacred tunebooks which began to appear for congregationai singing. "ITt invoived the incision of a text into a flat piate (at first usually copper, but later pewter); the plate was then inked and wiped clean so that the ink remaining in the incision was transferred to the paper during pressing." 1 Freehand engraving continued to be used throughout the eighteenth century, even after movable type was available.

Movable type was introduced into the colonies by Christopher Saur of Germantown, Pennsylvania, and used to produce a sacred music collection in 1752 . The first sacred tunebook printed with movable type was The Worcester Collection of Sacred Harmony (1786) published by Isaiah Thomas. It was a great success and appeared in eight editions by 1803 . Thomas became a prolific sacred music publisher, with more than 400 titles coming from his press. Movable type was employed more frequently in the 1780s with the importing of fonts from the Caslon foundry in London. This was the beginning of a sacred and secular music publishing industry in the United States. 
Often a publisher of sacred or secular music would also print his own compositions as well as engage in musical activities such as teaching, conducting, and operating a music shop. Some publishers sold music in their shops as well as musical instruments of various types; some even repaired or manufactured instruments.

Although the earliest popular sheet music appeared in a broadside (single-page) engraving of "The New and Favourite Liberty Song" in 1768 published by John Mein and John Fleming, ${ }^{2}$ it was not until the 1780s that a few attempts were made at publishing secular music. When nonreligious music was performed, it was mostly in the homes of the musically sophisticated. However, interest in nonreligious music grew continuously after the middle of the eighteenth century, encouraged by an influx of foreign musicians, opera companies, theatrical troupes, and popular entertainers. These performers brought with them the musical tastes in vogue in the concert rooms of their homelands and on the stages of London, Dublin, Paris, and other musical centers of England and Europe. Piano assignments of overtures, dances, marches, and similar forms were common, as were the popular songs of the theater and semi-operatic stage. ${ }^{3}$ Interestingly, a few secular pieces were also included in collections of sacred tunes by William Billings (1778), Samuel Holyoke (1791), and Oliver Holden (1792). ${ }^{4}$ By the second half of the eighteenth century, a strict separation between sacred and secular tunes was not always observed when publishing tunebooks, indicating that secular tunes were becoming increasingly popular.

\section{Popular or Secular Music}

The strongest evidence for a thriving secular musical culture in the colonies is the presence of musical instruments in households, the availability of music lessons, and public concerts. Lambert searched probate court records for the Massachusetts Bay Colony and uncovered a number of household inventories which included musical instruments. Of the 
probate records examined, dating between 1630 and 1730, 72 individuals owned a total of at least 108 instruments, ${ }^{5}$ including virginals, drums, citterns, viols, Jew's harps, gitterns, fifes, guitars, violins, flutes, trumpets, chamber organ, harpsichords, a clavichord, and a spinet. ${ }^{6}$ Upon their arrival, some colonists wrote to individuals in England asking them to send instruments. A 1661 letter is preserved from Leonard Hoar responding to a request for instruments from his nephew Josiah Flynt. ${ }^{7}$

From evidence in inventories and town records, there appears to have been three instrument makers working in the Massachusetts Bay Colony during the seventeenth century. They were Robert Crosman (d. 1692), who in 1640 was identified as a "drummaker"; Arthur Clarke (d. 1665), a woodworker and a fife maker; and John Dyer (d. 1696), an ironmaker and possibly pewter fife maker. Lambert suggests that musical instruments had a practical use in defense of the colony and that ironmonger Robert Cutler (d. 1665), who had "a pcell. [parcel] of Citternwier ... in the new Shop," also made cittern wire. $^{8}$ By 1699 , instruments also were being exported from London to New England, as indicated in a document in the Public Record Office in London that a cargo containing an unspecified number of "Musicall Instrumts" valued at fourteen $£$ was entered under "Lond.--Exportac" . of Eng. Manufactures from Xtmas. 1698 to Xtmas. 1699 With an Estimate of their first Cost or Value Viz ${ }^{\mathrm{t}} . " 9$

On 23 February 1713, George Brownell advertised in the Boston News-Letter that he offered lessons in "Writing, Cyphering, Dancing, Treble Violin, Flute, Spinnet \&c. Also English and French Quilting, Imbroidery, Florishing, Plain Work, marking in several sorts of Stiches."10 Besides his work as a teacher of various subjects and music, Brownell was also a dance teacher active in Charleston, South Carolina, from about 1703; in Boston from 1713 to 1718; in Arrosick, Maine, during 1720; in Chester, New Hampshire, from 
1722-1734; in New York from 1734-1735; in Boston from 1735 to 1738; in Philadelphia from 1744 to 1750; and in Charleston after 1750.11

One of the earliest music dealer's in Boston was Edward Enstone who was also an organist, dance and music teacher, instrument repairer, and keyboard tuner. Enstone has been traced to London during 1713 and 1714; he arrived in the colonies in 1715 to become organist at the King's Chapel in Boston. On April 16-23, 1716, he published the following advertisement in the Boston News-Letter:

This is to give Notice that there is lately sent over from London a choice Collection of Musikal Instruments, consisting of Flaguelets, Flutes, Haut-Boys, Bass-Viols, Violins, Bows, Strings, Reads for Haut-Boys, Books of Instructions for all these Instruments, Books of ruled Paper. To be Sold at the Dancing School of Mr. Enstone in Sudbury Street near the Orange-Tree Boston. Note. Any Person may have all Instruments of Musick mended, or Virgenalls and Spinnets Strung and Tuned at a reasonable rate, and likewise may be taught to Play on any of these Instrument above mention'd; dancing taught by a true and easier method than has been heretofore. ${ }^{12}$

The evidence recorded from Lambert's work indicates that the colonists brought instruments with them, sent for instruments from England, received instruments exported from England, and purchased instruments from makers in New England. The extent of secular musical activity in the colonies, however, will not be revealed until similar investigations into probate records are completed for Philadelphia, New York, and Baltimore.

On February 3rd and 10th, 1729 the earliest known public concerts in America were advertised in the Boston Gazette: 
This is to give Notice, That there will be a Consort of Musick performed on sundry Instruments, at the Dancing School in King-Street, on Tuesday the 18th Instant, at Six a Clock in the Evening, and that Tickets for the same will be delivered out at Seven Shillings and six pence each Ticket, at the Places following, viz. At Mr. Luke Vardy's at the Royal Exchange, at Mrs. Meer's at the Sun Tavern near the Deck, and at the Place of Performance. N.B. No Person to be Admitted after Six. ${ }^{13}$

Many other public concerts are reported in Boston and other colonial cities starting in the $1730 \mathrm{~s}$; these certainly can be seen as an impetus for publishing music for an interested public.

\section{The Introduction of Sheet Music}

The earliest secular music printed in the colonies appeared in the form of the broadside ballad. Some English broadsides were brought to the colonies, others were printed in Boston, Philadelphia, and New York. They usually consisted of a text on one page intended to be sung to a familiar tune. When a melody was printed on a broadside it served only as a reminder and was never newly composed. Many of these tunes have been preserved in oral tradition. Some tunes are found in notated instrumental music as airs for variation or in tutors and contemporary collections. During the Revolutionary period few Americans were musically literate. The sale of sheet music was a small business confined mostly to larger cities and to the most affluent, best-educated members of society, who were also those most likely to have some acquaintance with classical music. Popular vocal and keyboard music offered for sale was not markedly different in style from that of the

classical music of the era, merely simpler in structure and less technically demanding. ${ }^{14}$ The rise of American music education and the popularity of the piano soon contributed to a sharp increase in the market for sheet music for home use. 
A continuous business of sheet music printing in America began only after the Revolution. The earliest works were assembled from 1787 to 1789 by a group of prominent Philadelphians: Alexander Reinagle (composer), Thomas Aitken (engraver), Thomas Dobson (pressman), Henry Rice (bookseller), and Francis Hopkinson (composer and patron). They produced several major anthologies, including vocal and instrumental collections by Reinagle (notably a set of keyboard variations thought to be the first solely secular musical publication in the U.S.), Hopkinson's Seven Songs (1788), and a Roman Catholic service book. A continuous tradition of publishing was established by Moller and Capron in Philadelphia in 1793, and later by George Willig and Benjamin Carr. James Hewitt began publishing in New York in 1793, followed soon by George Gilfert and Frederic Rausch. In 1794 Thomas Carr started publishing in Baltimore followed in 1798 by Peter Albrecht von Hagen in Boston.

These music publishing firms were located in major urban centers and had close ties with the theatrical companies that were being founded at the time. Many of the publishers themselves had been theater musicians, and their catalogs consisted mainly of theater songs. At the turn of the century, two more major publishing houses were established: Gottlieb Graupner in Boston and George E. Blake in Philadelphia. While Philadelphia maintained its leadership through the shops of Willig and Blake, New York grew in importance through the work of smaller firms, including those of John Paff, Joseph Willson, the Geib family, and William Dubois. ${ }^{15}$

The establishment of a publishing industry during the 1790s was due to a series of events. These included the opening of the Chesnut Street Theatre in Philadelphia on February 17, 1794, and of the Park Street Theatre in Boston two weeks earlier. During the same time the Hallam and Henry "Old American Company" established a permanent home in New York, and an enormous amount of activity occurred in Charleston's theaters. 
In addition, these theater companies made their earliest tours to Baltimore and Hartford. Furthermore, managers of several companies made London recruiting trips, such as John Henry in 1792, Thomas Wignell in 1793, and Charles Stuart Powell in 1794. The significance of these events is reflected in some of the characteristics of the early sheet music repertory itself. For example, the origins of the repertory may be traced to imported London opera. Several songs were also written by local theater musicians, and there are similarities to the practices of publishers in London at this same time. ${ }^{16}$

\section{The Physical Nature of Sheet Music}

Music plates during the eighteenth and early nineteenth centuries were fairly large and customarily arranged so that two plates of pages were printed side by side on one side of a whole sheet of paper. Wolfe observed that songs of four pages were printed from four plates of which both sides of the sheet were used. Frequently, in the case of vocal music, only two pages were required for the entire work. The usual practice was to print both of these pages on one side of a whole sheet of paper. The paper was then folded down the middle so that the two pages faced one another inside and the outside pages were blank. (This arrangement may have been considered the best way of protecting the printed text.) $)^{17}$ From 1790 to about 1810 the actual size of the paper averaged 32.5 centimeters long by 25 centimeters wide. From about 1810 to about 1840 the dimensions increased to about 34 centimeters long by 25.5 centimeters wide. ${ }^{18}$

A new printing method called lithography was introduced during the late $1820 \mathrm{~s}$. It involved a flat printing surface marked, dampened, and then inked so as to leave ink on only the marked areas for transfer to the paper. First introduced in America by Henry Stone in Washington, D.C., around 1822, it was used more extensively in New York five years later by Edward S. Mesier, Anthony Fleetwood, and G. Melkham Bourne. ${ }^{19}$ 


\section{Genres of Popular Music}

Crawford and Krummel found that of 800 titles of sheet music published from 1793 to 1801 , three-quarters were imported from the English stage. Most were songs from the comic operas, some were from dramatic works composed by James Hook, William Shield, Charles Dibdin, Stephen Storace, and Samuel Arnold. Another genre included patriotic music with titles such as "Adams and Liberty," "Hail Columbia," "New Yankee Doodle," and "Dirge for General Washington."20 The American composers were mostly musicians in the theaters, many of whom became publishers or engravers, including Alexander Reinagle, J.C. Moller, Henri Capron, Peter Albrecht von Hagen, George Gilfert, William Priest, George Gillingham, Benjamin Carr, James Hewitt, Victor Pelissier, Rayner Taylor, William Dubois, and Gottlieb Graupner.

Music published from 1801 to 1830 continued to include a number of works from the English stage, such as "Love in a Camp," "Rosina," and "The Poor Soldier" by William Shield, "The Children in the Wood" and "Zorinski" by Samuel Arnold, Charles Dibdin's "The Deserter," Stephen Storace's "No Song, No Supper," and Thomas Arne's "Love in a Village." The earliest American song writers include Francis Hopkinson, Oliver Shaw, and musicians whose works appear in The American Musical Miscellany (1798).

Other categories of popular music published in America include Scottish and Irish melodies, such as James Hook's "Within a Mile of Edinboro' Town;" several arrangements of the anonymous "The Blue Bells of Scotiand;" and a number of songs by Robert Burns ("John Anderson my Jo," "Auld Lang Syne," and "Comin' thro the Rye") set to traditional tunes. By the second decade of the nineteenth century songs from the Italian operas by Mozart and Rossini became popular in simplified arrangements for voice and keyboard. Several songs from "Englished" versions of Italian opera also were printed. 
A final category of music which became popular during the 1820 s were songs of the minstrel stage. Early examples include songs from ballad and comic operas depicting a black slave as a minor character singing songs considered "appropriate." For example, Stephen Storace's "Poor Black Boy" from The Prize (1793) and Charles Dibdin's "Yanko Dear" have deliberately simplistic music (though they have nothing to do with authentic African styles), and lyrics in heavy dialect. During the 1820 s a number of popular Caucasian performers incorporated the speech patterns and physical characteristics of American Blacks into their popular stage acts. These performers included Charles Mathews, George Nichols, Bob Farrell, George Washington Dixon, and Thomas Dartmouth ("Daddy") Rice. 21 Many of these comic "Negro" songs were published as sheet music.

\section{Performing Media}

American sheet music repertoire of the period from 1793 to 1830 , as found in the Huntington's collection, consists primarily of songs for voice and piano accompaniment, although occasionally the accompaniment would be written for harp or guitar. Piano solos are more frequently seen after 1800 , along with arrangements for piano four hands. Solos for flute with piano accompaniment and collections for guitar appear during the first and second decades of the nineteenth century. Following the English tradition, a few songs were published with transposed arrangements of the melody written for the flute, and more occasionally for violin, guitar, clarinet, or flageolet. Some composers during the early nineteenth century were announced in newspaper notices as the creators of the "accompanements" for the theater, that is, the re-orchestrations of works imported from London in sheet music. In several of these songs cues were included for different orchestral instruments such as flute, oboe, trumpet, drum, corni (horns), clarinet, cello, 
and violin in the piano accompaniment. The published arrangements, which include several optional instruments, indicate that a variety of instruments were available either from the publisher or from music stores which sold such musical merchandise.

\section{Conclusion}

From the late seventeenth century many American colonists were actively involved in perfoming music for their own amusement or for signalling in time of danger. A variety of instruments were brought and imported from England and bought from colonial makers during the late seventeenth century. Music lessons were first advertised in the colonies in 1713 and a proliferation of public concerts began in 1729. It was not until 1793, however, that the population was sufficiently large and diverse to support a number of publishers in Philadelphia, New York, Boston, and Baltimore. The majority of the music published consisted of songs from the English and American theater. Other categories or genres of music published during the eighteenth and nineteenth centuries included patriotic music, Scottish and Irish melodies, and songs of the minstrel stage.

\section{Endnotes}

1D. W. Krummel, "Publishing and Printing of Music," The New Grove Dictionary of American Music (New York: Macmillan, 1986), vol. 3, p. 651.

${ }^{2}$ This broadside has not been found, however, a reproduction of the advertisement in the Boston Chronicle on October 17, 1768 in William Arms Fisher, Notes on Music in Old Boston (Boston: Oliver Ditson Company, 1918), p. 17.

${ }^{3}$ Richard J. Wolfe, Early American Music Engraving and Printing (Urbana: University of Illinois Press, 1980), pp. 176-77.

${ }^{4}$ See Oscar George Theodore Sonneck, A Bibliography of Early Secular American Music [18th Century], rev. by William Treat Upton (Washington D.C.: The Library of Congress, $1945)$, pp. 16, 179-80, 384-85. The secular numbers are specifically cited by Sonneck in 
these collections. Although these collections are held in the Huntington Library's collection they were not included in the listing of secular tunes in the appendix. Furthermore, a few other secular works are found in periodicals such as the Massachusetts Magazine (vols. i to iv, 1789-1792) and are also not included in the listing of secular tunes.

5See Barbara Lambert, "Social Music in Colonial Boston," Music in Colonial Massachusetts 1630-1820, ed. B. Lambert (II: Music in Homes and in Churches; Boston: The Colonial Society of Massachusetts, 1985), pp. 415, 419.

${ }^{6}$ Lambert, Table 1: Musical Instrument and Their Owners from the Inventories of Suffolk, Middlesex, and Essex Counties, pp. 422-31.

${ }^{7}$ Lambert, pp. 478-79.

${ }^{8}$ Lambert, p. 510.

${ }^{9}$ Lambert, p. 511.

${ }^{10}$ This advertisement was repeated in the Boston News-Letter from February 23 through March 16, 1713. Brownell's advertisement of March 2 is reproduced by Cynthia Adams Hoover in "Epilogue to Secular Music in Early Massachusetts," Music in Colonial Massachusetts 1630-1820 (II: Music in Homes and in Churches; Boston: The Colonial Society of Massachusetts, 1985), Fig. 385, p. 739. See also, Lambert in "Appendix C: Music Masters in Colonial Boston," Music in Colonial Massachusetts 1630-1820 (II: Music in Homes and in Churches; Boston: The Colonial Society of Massachusetts, 1985), p. 955.

"Lambert, "Appendix C: Music Masters in Colonial Boston," p. 954. For a reproduction of a manuscript bill from George Brownell for dancing lessons and tuning a spinet dating 15 April 1718, see Lambert "Social Music in Colonial Boston," Fig. 242, p. 449.

${ }^{12}$ Oscar George Sonneck, Early Concert-Life in America (1731-1800) (Leipzig: Breitkopf \& Härtel, 1907), p. 9, n. 1; George Francis Dow, The Arts \& Crafts in New England 1704-1755 (Topsfield, Masachusetts: The Wayside Press, 1927), p. 297; Reproduced by Lambert as Fig. 276, p. 511, see also Lambert, "Appendix C: Music Masters in Colonial Boston," pp. 970-74.

${ }^{13}$ Lambert, 409; the advertisement is reproduced as Fig. 237, p. 410.

${ }^{14}$ Charles Hamm, "Popular Music," The New Grove Dictionary of American Music (New York: Macmillan, 1986), vol. 3, pp. 589, 591 
${ }^{15}$ See D.W. Krummel, "Publishing and Printing of Music, §2: Sheet music to 1865 ," The New Grove Dictionary of American Music (New York: Macmillan, 1986), vol. 3, p. 652; Richard Crawford and D.W. Krummel, "Early American Music Printing and Publishing," Printing and Society in Early America, ed. William L. Joyce et al. (Worcester: American Antiquarian Society, 1983), p. 202.

${ }^{16}$ Crawford and Krummel, p. 203.

${ }^{17}$ Wolfe, p. 181 .

${ }^{18}$ See Nicholas E. Tawa, Sweet Songs for Gentle Americans: The Parlor Song in America, $1790-1860$ (Bowling Green, Ohio: Bowling Green University Popular Press, 1980), p. 103; and compare the dimensions of sheet music in Richard J. Wolfe, Secular Music in America, 1801-1825; a Bibliography (New York: The New York Public Library, 1964).

${ }^{19}$ Krummel, "Publishing and Printing of Music," p. 652. The last three publishers are represented in the Huntington's collection.

${ }^{20}$ Several of these songs are found in the Huntington Library's collection see Appendix A. See also Sonneck, pp. 571-2 for his "List of American Patriotic Music."

${ }^{21}$ See Hamm, "Popular music," p. 591. 


\section{CHAPTER TWO \\ LITERATURE REVIEW}

Introduction

There are two categories of publications that this literature review addresses: primary and secondary sources of information. Primary sources are the sheet music itself and republications of sheet music. Secondary sources are listings of sheet music or publishers; studies on the history and development of publishing, printing, and lithography; books on the music industries of Boston and New York; and studies of musical instrument makers and instruments.

\section{Primary Sources}

There are two recent series that reprinting manuscript and sheet music some of which dates from the late eighteenth and early nineteenth centuries. The first is entitled Three Centuries of American Music: A Collection of American Sacred and Secular Music. ${ }^{1}$ This multi-volume series contains reprints of sacred and secular American music; ethnic or folk music is not included. Each volume has a contributing editor who provides an introduction to the organization and choice of the music examples which are reprinted from the original publications. The second series includes a number of reprinted instrumental and vocal pieces and is entitled Recent Researches in American Music. Of the sheet music in the Huntington Library's collection the following were found to have been reprinted: "The battle of Trenton" (1797, appendix no. 6) by James Hewitt; "The wounded hussar" (1798-1804, no. 17) by James Hewitt; "Why huntress, why" (18001801, no. 24) by Benjamin Carr; "The Copenhagen waltz" (1817-18, no. 106); ${ }^{5}$ and "Moran's favourite variations to the Suabian air" (1826-51, no. 408). ${ }^{6}$ 


\section{Secondary Sources: Listings and Directories of Publishers}

Three essential secondary sources were written by Oscar George Sonneck, Richard J. Wolfe, Hairy Dichter, and Elliot Shapiro. Sonneck's book, A Bibliography of Early Secular American Music [18th Century], is a bibliography originally published in 1907 and enlarged and expanded by William Treat Upton in $1945 .^{7}$ It is a comprehensive alphabetical listing by title of eighteenth-century music published in the United States.

Each listing includes a short description of the instrumentation, the first line of the text if it includes a text, commentary which may include the newspaper in which the work was advertised, and an abbreviated listing of libraries or archives that own the music. It includes librettos without music. This edition includes a list of all composers mentioned in the text as having had compositions published in the United States during the eighteenth century; a list of songsters or collections of songs; a list of first line, title, and composer of each work; a list of American patriotic music (songs without music are not included); a list of opera librettos by title, librettist, and composer; an index of publishers, printers, and engravers in Philadelphia, New York, Boston, Baltimore, and elsewhere with reference to their publications by page number; and a general index.

Richard J. Wolfe's three-volume Secular Music in America 1801-1825: A Bibliography is essential to the study of sheet music during this period. ${ }^{8}$ This extensive work covers every title known to the author, whether located or not, and includes a description, commentary, and a list of libraries holding each work. The bibliography is interleaved alphabetically by title and composer. There is an addenda of further works, and three appendixes: unrecorded eighteenth-century imprints; redated imprints; and additional copies of eighteenth-century imprints. There are five indexes: titles; first lines; publishers; engravers and printers; publisher's plate and publication numbering systems; and a general index. There is also an errata section. 
Harry Dichter and Elliot Shapiro's book, Early American Sheet Music: Its Lure and Its Lore 1768-1889, includes a number of interesting and valuable sections. ${ }^{9}$ The introductory matter includes several sections with significant facts, usually chronologically arranged, concerning broadsides and periodicals, first editions, early musical copyrights, and famous American musical firsts. Part one consists of a listing of early American sheet music under a number of categories including presidents of the United States, 1789-1941. A second subdivision from 1768 to 1810 includes the following categories: music of the American revolution; early music; early patriotic and historical items; Yankee Doodle; and Hail Columbia. Five more sections are chronologically divided: from 1811 to $1829 ; 1830$ to $1849 ; 1850$ to $1859 ; 1860$ to 1869 ; and 1870 to 1889 . A number of categories are included under each of these sections. Part two, a "Directory of Early American Music Publishers," is a valuable section for the dating of the business activities of sheet music publishers. It is arranged alphabetically with dates, names of companies, and addresses of publishers. Part three is a list of "Lithographers and Artists Working on American Sheet Music Before 1870" by Edith A. Wright and Josephine A. McDevitt. A short bibliography is followed by several reproductions of title pages.

Another important secondary source with a variety of information concerning publishers and the publishing trade is the Guide for Dating Early Published Music: A Manual of Bibliographical Practices, edited by Donald W. Krummel. ${ }^{10}$ This guide consists of sections written by members of the International Association of Music Libraries, complied by Krummel. The preface includes sections on early musical editions, the need for dating, background and plan, and a section containing basic rules for dating music. The beginning of the next section includes a synopsis with ten sections: introduction; plate numbers; publishers' addresses; copyright and registration; announcements; house practices; other evidence; authorities cited; selected list of writings; and a glossary of 
terms in English, French, and German. The third and largest section is entitled national reports and consists of a summary of questions addressed to a specialist for each country surveyed. The seventeen sections are devoted to the following countries: Great Britain, The Netherlands, Belgium, France, Spain, Italy, Switzerland, Germany, Austria, Czechoslovakia, Hungary, Poland, Denmark, Sweden, Russia, United States, Canada, and Brazil. This is followed by a postscript, a list of illustrations, and an index. Two later supplements published as journal articles are included in a pocket at the end of the book: D. W. Krummel's "Supplement to the Guide for Dating Early Published Music"11 and Linda I. Solow's "An Index to Publishers, Engravers, and Lithographers and a bibliography of the Literature cited in the IAML Guide for Dating Early Published Music."12

The Newberry Library Catalog of Early American Printed Sheet Music, compiled by Bernard $\mathrm{E}$. Wilson, was useful for verifying dates assigned to sheet music in the Huntington Library's collection. ${ }^{13}$ This catalog provides a reprint of the card catalogs of the early American printed sheet music in the Newberry Library of Chicago. The Newberry houses the J. Francis Driscoll Collection, one of the most comprehensive and important collections of American imprints with over 20,000 sheets of music. An informative introduction by Bernard Wilson is found in volume one. A source which dates theatrical productions in New York city is George Odell's Annals of the New York Stage. ${ }^{14}$ It was consulted when a reference to a theatrical production was made in the title and the other bibliographical secondary sources provided only a broad range of dates.

\section{Studies on the History and Development of Music Publishing and Printing}

One of the most illuminating studies concerning various aspects of publishing and printing in early American society is Richard J. Wolfe's Early American Music Engraving 
and Printing: A History of Music Publishing in America from 1787 to 1825 with Commentary on Earlier and Later Practices. ${ }^{15}$ Its chapters include, "The Arrival of Musician-Engravers and the Establishment of a Music-Publishing Industry;" "The Early American Music-Publishing Firm;" and "Dating Early Music." Appendix C is an important compilation of watermarks found on American music sheets from 1787 to 1830 . Another excellent study is the article by Richard Crawford and Donald W. Krummel entitled "Early American Music Printing and Publishing" in Printing and Society in Early America. ${ }^{16}$ This article presents a detailed discussion of the origins of American secular and sacred music including the business practices of composers, printers, engravers, and publishers and why many individuals performed several of these tasks. The authors discuss the use of music fonts as opposed to engraved plates, and the nature and printing techniques of sheet music.

Another useful reference source particularly for biographies of music publishers is Music Printing and Publishing, edited by Donald W. Krummel and Stanley Sadie. ${ }^{17}$ This handbook is divided into four parts: music printing by $\mathrm{H}$. Edmund Poole; music publishing by D. W. Krummel; a dictionary of music printers and publishers (contributed by many authors), including a glossary by Stanley Boorman; and a bibliography by D. W. Krummel. The articles were all reprinted from The New Grove Dictionary of American Music published in 1986. There is also an extensive index.

Two additional articles in a specialized dictionary include useful historical summaries of their topics. Charles Hamm's "Popular Music" in The New Grove Dictionary of American Music presents a detailed discussion of popular music in America. ${ }^{18}$ It is divided into four sections: European origins; early American song and piano music; the Tin Pan Alley era; and the rock era. Two sheet music covers are reproduced and there is an extensive bibliography at the end. Donald W. Krummel's 
"Publishing and Printing of Music" in The New Grove Dictionary of American Music presents a detailed history of music publishing in the United States. ${ }^{19}$ It is divided into four sections: early sacred music publishing; sheet music to 1865 ; commercial activity 1865-1945; and developments since 1945. A bibliography is included at the end.

One specialized article concerning lithography and its use in American sheet music includes some important information. Nancy R. Davison's "The Grand Triumphal Quickstep; or, Sheet Music Covers in America" in Prints in and of America to 1850 provides a history of the use of lithography on American sheet music covers. ${ }^{20}$ The information presented was useful in chapter four for the discussion of lithographic covers at the Huntington Library.

\section{Studies of Music Printing, Publishing, and Instrument Making in Boston and New York}

Four studies of music publishing, printing, and instrument making in Boston provide valuable information. Music in Colonial Massachusetts $1630-1820$, edited by Barbara Lambert, comprises a variety of essays in two volumes originally delivered at a conference held by The Colonial Society of Massachusetts on May 17 and 18, 1973.21 This source was particularly important in providing information concerning the use of musical instruments, music lessons, and concert activity. The topics of the essays are: dance manuscripts in eighteenth-century America; military music of colonial Boston; broadsides and their music; eighteenth-century Massachusetts songsters; Massachusetts musicians and the core repertory of American psalmody; William Price and Thomas Johnston; organs and organ building in eighteenth-century New England; secular music in early Massachusetts; and social music, musicians, and their musical instruments. Appendices include a list of drums, criers and bells in the colonies; a list of music masters in colonial Boston; and musical theses at colonial Harvard. 
H. Earle Johnson's Musical Interludes in Boston 1795-1830 is a classic study of early nineteenth-century Boston musical culture, concert life, the Philharmonic Society, the von Hagen family, Graupner, Jackson, and contains separate chapters concerning publishers, music dealers and manufacturers, and teachers. ${ }^{22}$ Appendixes comprise a list of publications by von Hagen; leading vocalists appearing in Boston; a catalog of Graupner publications; a list of lesser publishers in Boston; and a list of musical works for which copyright was granted between January 1, 1791, and September 1, 1827.

An important study concerning music publishers and instrument makers is Contributions to the Art of Music in America by the Music Industries of Boston 1640 to 1936 by Christine Merrick Ayars. ${ }^{23}$ This study reviews the contributions of Boston's music industries from the seventeenth century through the twentieth, including music publishing, music engraving and printing, and instrument making. There are number of appendices which list various musical instrument makers.

Notes on Music in Old Boston, by William Arms Fisher, reproduces several advertisements culled from eighteenth and nineteenth century newspapers and provides an historic overview of music publishing in Boston. ${ }^{24} \mathrm{He}$ also provides a detailed history of the Oliver Ditson Company, an important publisher active during the nineteenth and twentieth centuries. Subsequent investigators have refined and extended the information concerning publishers presented by Fisher.

Two sources concerning music publishing, engraving, and instrument makers in New York were useful for this study. The Music Directory of Early New York City by Virginia Larkin Redway provides several lists of musicians, music publishers, and musical instrument makers and their addresses in the New York City directories from 1786 through 1835. She also provides a compilation of publishers listed in the directories from 1836 through $1875 .{ }^{25}$ There is a short but informative introduction. Musical Instrument 


\section{Makers of New York: A Directory of Eighteenth-and Nineteenth-Century Urban}

Craftsmen by Nancy Groce, supersedes Redway's book regarding musical instrument makers. ${ }^{26}$ This directory consists of an alphabetically list of several hundred instrument makers and craftsmen (some of whom published music) active in New York up to 1900. The address and activity of each craftsmen are also provided.

\section{Musical Instruments and Musical Instrument Makers}

Books concerning musical instruments and their makers have been useful in this study. They include one general study of American instruments, two studies of the piano, two studies of wind instrument makers, a study of the keyed bugle and its makers, and a study of the recorder. Laurence Libin's American Musical Instruments in The Metropolitan Museum of Art presents a comprehensive overview of American musical instruments in the Metropolitan Museum of Art, placing each instrument within the culture of its time. ${ }^{27}$ This detailed presentation discusses all types of musical instruments and provides a wealth of biographical detail concerning the makers, who were often music publishers.

Daniel Spillane's History of the American Pianoforte: Its Technical Development. and the Trade is a classic history of the American piano. ${ }^{28}$ Spillane discusses precursors of the piano and several European makers. American makers are discussed in separate chapters under individual cities. However, some subsequent scholarship has shown that some of Spillane's statements to be incorrect. The most recent and important survey of piano makers is Martha Novak Clinkscale's Makers of the Piano 1700-1820. ${ }^{29}$

Clinkscale's list of 4,000 extant pianos made from 1700 to 1820 is organized by piano maker and includes biographical details concerning 900 makers. 
An important source concerning musical wind instrument makers is Lyndesay G. Langwill's An Index of Musical Wind-Instrument Makers. ${ }^{30}$ This index of musical wind instrument makers provides an alphabetical listing of individual musical instrument makers and companies, several of which were also music publishers. As a reference work, it sometimes augments the information found in other works concerning music publishers. William Waterhouse's The New Langwill Index: A Dictionary of Musical Wind-Instrument Makers and Inventors is a recent book that is much more than an updated edition of Langwill's book. ${ }^{31}$ It is a comprehensive listing of about 6,400 wind instrument makers and dealers. Biographical information is given for the majority of makers and dealers, along with the location of selected instruments; information concerning the maker's marks; maker's addresses; patents; catalogs of makers; exhibition catalogs; and a bibliography of sources concerning the maker. A list of museums referred to in the text is given along with an index of makers by city and a substantial bibliography. A comprehensive biographical listing of violin and stringed instruments makers is Thomas James Wenberg's The Violin Makers of the United States. ${ }^{32}$ It is an alphabetical listing of all violin and stringed instrument makers who were and are presently active in the United States. In his entries Wenberg often describes the workmanship of selected instruments by each maker. A few musical instrument dealers and publishers are also mentioned as are extant instruments bearing their labels.

A history of the keyed bugle and its music is presented by Ralph T. Dudgeon in a recently published book entitled The Keyed Bugle. ${ }^{33}$ A revision of Dudgeon's dissertation, it includes a separate chapter on keyed bugle makers and sellers. Nancy Gamble Pressley's "Winterthur Museum's Early American Keyboard and Music Collection: An Example of Museum Resources for Music in Higher Education" (Ph.D. diss., Southern Illinois University at Carbondale, 1982) includes advertisements of pianos and other instruments 
by American dealers in early nineteenth-century newspapers. Edgar Hunt's The Recorder and Its Music provides chapters concerning the history of the recorder and its music, the design of recorders and recorder makers, and recorder technique. ${ }^{34}$ The latter is useful in understanding the notation of recorder parts marked "flute" in sheet music of the late eighteenth and early nineteenth centuries.

\section{Conclusion}

The literature concerning sheet music and its publishers and engravers from the earliest period of American activity is somewhat limited. Reprints of sheet music are limited to two relatively recent series and the vast majority of music can only be studied by viewing the original sheets. Two main sources are invaluable bibliographical listings compiled by Sonneck and Upton (1945) for the eighteenth century, and Wolfe (1964) for 1801 to 1825 . Another useful source completed in 1941 is Dichter and Shapiro's "Directory of Early American Music Publishers."

The most important study of early American music engraving and printing is Wolfe's book (1980). He thoroughly discusses a number subjects up to 1825 . Several biographies of publishers are also covered in Krummel and Sadie's handbook (1990) although this material is also found in The New Grove Dictionary of American Music (1986). A wealth of valuable material is found in the various studies concerning music printing, publishing, and instrument making in Boston and New York. The most important study of American musical instruments is Libin's (1985), who discusses a large variety of examples preserved in the Metropolitan Museum of Art and the activities of their makers. Specific biographical listings of American makers and their instruments have appeared in the publications by Wenberg (1986), Clinkscale (1993), and Waterhouse (1993). With these sources makers of three of the major families of instruments have been 
thoroughly investigated, although additions and corrections to these invaluable works will continue to occur.

A very large but important project would be the updating and correction of both of Sonneck-Upton and Wolfe (1964). Cataloged sheet music records are now available via machine-readable databases. Dichter and Shapiro's "Directory of American Music Publishers" is badly in need of updating and correcting. The list of publishers can surely be expanded and corrections and additions need to be made for addresses of publishers. The development of lithography in American sheet music could be covered in much greater detail then is found in Wolfe (1980) and Davison (1970). Makers of percussion instruments and mechanical and automatic instruments are in need of reference manuals similar to those written by Wenberg (1986), Clinkscale (1993), and Waterhouse (1993). Furthermore, a number of American instruments have not yet been thoroughly studied.

\section{Endnotes}

${ }^{1}$ General eds. Martha Furman Schleifer and Sam Dennison (Boston: G.K. Hall \& Co., 1989-1990), 5 vols.

2James Hewitt, Selected Compositions, ed. J. W. Wagner (Recent Researches in American Music, 7, Madison: A-R Editions, 1980), 88-106.

${ }^{3}$ Ibid, 46-7.

${ }^{4}$ Benjamin Carr, Selected Secular and Sacred Songs, ed. E. R. Mayer (Recent Researches in American Music, 15; Madison: A-R Editions, 1986), 10-12.

5Anthology of Early American Keyboard Music 1787-1830, Part I, ed. J. B. Clark (Recent Researches in American Music, 2; Madison: A-R Editions, 1977), 114-18.

6Ibid, Part II, 9-15.

${ }^{7}$ (Washington, D.C.: The Library of Congress, 1945).

${ }^{8}$ (New York: The New York Public Library, 1964). 
${ }^{9}$ (New York: R.R. Bowker Co., 1941).

${ }^{10}$ (Hackensack, N.J.: J. Boonin, 1974).

11 Fontes Artis Musicae 24 (1977): 175-184.

${ }^{12}$ Fontes Artis Musicae 24 (1977): 81-95.

${ }^{13}$ (Boston: G.K. Hall \& Co., 1983), 3 vols.

${ }^{14}$ (New York: Columbia University Press, 1927-1949), 15 vols.

${ }^{15}$ (Urbana: University of Illinois Press, 1980).

${ }^{16}$ Eds., William L. Joyce, David D. Hall, Richard D. Brown, and John B. Hench, (Worcester: American Antiquarian Society, 1983), 186-227.

${ }^{17}$ (The Norton/Grove Handbooks in Music, New York: W.W. Norton), 1990.

${ }^{18}$ Ed. Stanley Sadie (New York: MacMillan, 1986), 3: 589-610.

${ }^{19}$ Ed. Stanley Sadie (New York: MacMillan, 1986), 3: 650-654.

${ }^{20} \mathrm{Ed}$. John D. Morse (Charlotesville: The University Press of Virginia, 1970), 257-94.

${ }^{21}$ (Music in Public Places, 1; Boston: The Colonial Society of Massachusetts, 1980) vol. 1; (Music in Homes and in Churches, 2: Boston: The Colonial Society of Massachusetts, 1985).

${ }^{22}$ (New York: Columbia University Press, 1943).

${ }^{23}$ (New York: The H.W. Wilson Company, 1937; reprint ed., New York: Johnson Reprint Corporation, 1969).

${ }^{24}$ (Boston: Oliver Ditson Company, 1918).

${ }^{25}$ (New York: The New York Public Library, 1941).

${ }^{26}$ (Annotated Reference Tools in Music, 4; Stuyvesant, New York: Pendragon Press, 1991).

${ }^{27}$ (New York: W.W. Norton \& Company, 1985).

${ }^{28}$ (New York: The Author, 1890; reprint ed., New York: Da Capo, 1969). 
${ }^{29}$ (Oxford: Oxford University Press, 1993).

30 6th ed. (Edinburgh: The Author, 1980).

${ }^{31}$ (London: Tony Bingham, 1993).

${ }^{32}$ (Mt. Hood, Oregon: Mt. Hood Publishing Co., 1986).

${ }^{33}$ (Metuchen, New Jersey: The Scarecrow Press, 1993).

${ }^{34}$ Revised ed. (London: Eulenberg Books, 1977). 


\section{CHAPTER THREE \\ MUSIC TRADES 1716 TO 1830 \\ Introduction}

Chapter one reviewed the evidence of an active musical life in colonial America: many colonists played musical instruments, others constructed instruments, and both music and instruments were imported from Europe. During the eighteenth and early nineteenth centuries a continual influx of musicians, teachers, instrument makers, and merchants into Boston, Philadelphia, and New York encouraged the performance and appreciation of music. The establishment of theaters and outdoor pleasure gardens in these cities during the late eighteenth century fostered the popularity and publication of songs performed at these locations. Furthermore, ownership of a square piano became a status symbol among the wealthy and middle classes. In addition, a significant social component of woman's education was musical training in girls' school or seminaries, or at home by a music teacher. ${ }^{1}$ By the late eighteenth century a number of commercial activities became established in large cities in the manufacture, importation, and sale of printed music, musical instruments, and accessories.

This chapter presents a history of the music trades in America from 1716 to 1830. The first section discusses the earliest individuals whose activities included selling music or musical instruments in colonial America. The second section discusses twelve publishers who dealt with or made musical instruments during the early nineteenth century, eleven of whom are represented by sheet music in the Huntington Library's collection.

\section{Music and Instrument Dealers, 1716-1807}

Boston is the first location where musical activity has been documented in colonial America. Only a handful of individuals are known to have sold music and instruments 
here and in New York or Philadelphia, during the entire eighteenth century. As noted in Chapter one, the earliest music dealer in colonial America was the Englishman Edward Enstone who was active in Boston from 1715 to 1724 . In addition to being an organist, dancing instructor, and music teacher, he repaired and tuned virginals and spinets. Enstone's advertisement in the Boston News-Letter of April 16,1716, indicates that he had received from London flageolets, flutes, oboes, bass viols, violins, bows, strings, oboe reeds, and books of instructions for all of these instruments.

Before the end of the century at least four other individuals sold musical accessories in Boston. The dancing and music master Increase Gatchell (d. 1729), active from 1722 to 1729, advertised in The New-England Courant, May 25-June 1, 1724, "Choice good Italian Fiddle-Strings, to be sold by Increase Gatchel in King Street."2 William Price, a print dealer, offered "Flutes, Hautboys, \& Violins, Strings, Musical Books, Songs" in an advertisement in the Boston News-Letter for September 22, $1743 .^{3}$ Price also advertised "Flutes, Hautbois, Violin \& String musical books and Songs" available at his "House \& Picture Shop" on a map entitled the "South-East View" of Boston engraved by William Burgis in the same year. ${ }^{4}$ The merchant Lewis Deblois included instruments in his general store as early as 1757, and in 1773 his son Gilbert offered "French Horns, Bassoons, Hautboys, Fifes, Drums, English \& German Flutes [recorders and transverse flutes], Violins, Roman Strings, Bows, Space Reeds, with Tutors for each sort of Instrument, which are so very plain \& easy as the Learner may soon make himself Master of it."5

Beginning in the 1760s sacred music such as "William's Universal Psalmodist" could be obtained in book stores and circulating libraries such as the London Book-Store, operated by James Rivington from 1762 to 1765 and John Mein from 1765 to $1771 .^{6}$ Instrumental music and songs issued as sheet music began to be sold at least as early as 
1783 in Ebenezer Battele's Boston Book-Store. ${ }^{7}$ Although the vast majority of instruments were imported from England during the seventeenth and eighteenth centuries, a few instruments were made in colonial America.

The earliest extant colonial instrument appears to be an anonymous drum made in New England between 1675 and 1700 preserved at the Connecticut Historical Society in Hartford, Connecticut. ${ }^{8}$ Two musical instruments made in 1739 are the earliest dated examples: a drum by Robert Crossman of Taunton, Massachusetts, in the Old Colony Historical Society in Taunton and a spinet by Johannes Gottlob Clemm (1690-1762) of Philadelphia in the Metropolitan Museum of Art. ${ }^{9}$

By 1759 Michael Hillegas opened the earliest music shop in Philadelphia and offered a variety of goods as advertised in the Pennsylvania Magazine on December 13.

To be sold by MICHAEL HILLEGAS at his house in Second-street, opposite Samuel Morris. Esq: an extraordinary good and neat Harpsichord with four stops; a good Violoncello, an Assortment of English and Italian Violins; as well common ones as double lined, of which some extraordinary; a Parcel of good German flutes imported here from Italy. Also imported in the last Ships from London, a large Assortment of Musick, of the best Masters, viz. Solos, Overtures, Concerto's, Sonata's and duets, for Violins, German Flutes, Hautboys, French Horns, Violoncello's and Guitars, Voluntaries, and Lessons for Organs and Harpsichord, ruled Paper of various sorts for Musick, and Musick Books, Tutors, of Books of Instructions to learn to play on the Violin, German Flute, Hautboy or Common Flute, without a Master, Song Books, Cantatas, Songs in Sheets, and a choice Parcel of Violin Strings, etc. ${ }^{10}$ Besides offering a large harpsichord, Hillegas had for sale a cello, violins, and transverse flutes along with a wide assortment of music for violin, flute, oboe, French horn, cello, guitar, and organ. He also offered instruction books or tutors for violin, flute, 
oboe or recorder; song books; sheet music; and violin strings. From 1757 to 1760 Hillegas obtained his music and instruments from John Johnson of London, a publisher, printer, and violin maker. Eleven drafts of letters from Hillegas to Johnson are preserved in the Pennsylvania Historical Society. In a 1764 advertisement in the Pennsylvania Gazette, Hillegas enlarged his inventory with the following instruments: "little Violins, Kitts, Violin [probably Viola] d'Amours, Psalters, Clarinets, Welch Harps, and Monochords," and added accessories such as mutes, rosin, and oboe reeds. ${ }^{11}$ Hillegas later became the first Treasurer of the United States, a member of the American Philosophical Society, a member of the Library Company, and completed some work as an historian for the Pennsylvania General Assembly. He remained active as a music dealer until the Revolutionary War began in 1776.12

In New York, just prior to Michael Hillegas's announcement, an anonymous gentleman offered in The New York Mercury for August 13, 1759, a large collection of music and "good German flutes, for three Dollars each; likewise others with 2, 3, 4 or 5 middle Pieces to change the Tones and voice . . . two fine Violins, a Girls six-stringed Bass Viole . . ."13 A similar advertisement with many of the same instruments appeared in the July 25,1764 , issue of the Boston Gazette and it is assumed that this anonymous gentleman had arrived in Boston by this time. ${ }^{14}$

The earliest musical instrument dealer active in New York was Thomas Harrison. Harrison offered "Spinnets, Violins, German Flutes, Musick Books, ruled Paper, Fiddle Strings, Bridges, Pins, Jacks for Spinnets, Hautboys and Hautboy Reeds" in the March 30, 1761, supplement issue of The New-York Gazette. ${ }^{15}$ Probably the earliest instrument maker in New York was Gottlieb Wolhaupter who offered "German Flutes, Hautboys, Clareonets, Flageolets, Bassoons, Fifes" in the November 16, 1761, issue of The NewYork Gazette. ${ }^{16}$ During the 1760 s and 1770 s several other dealers and makers were 
active in New York including: Robert Horne (1767-72, maker); Simeon Coley (1767, dealer); John Balthius Dash (1769-83, maker); Peter Goelet (1769, dealer); John Sheiuble (1772-74, maker), and Daniel and Philip Pelton (1775, makers). ${ }^{17}$ In Boston, James Juhan (1769-72, maker) and Isaac Greenwood (1771-1785, dealer) were active. ${ }^{18}$ One of the most commercially successful music dealers of the 1780s was John Jacob Astor in New York. Although Astor invested in furs and sold them in England shortly after he arrived in New York in 1783, in 1786 he opened a music shop at 81 Queen Street. His merchandise was imported from his brother George in London and included pianos, spinets, guitars, violins, flutes, clarinets, oboes, fifes, music books, paper, and strings. In 1802 Astor sold his business to Michael and John Paff, but continued to import instruments as late as 1807.19

During the eighteenth and early nineteenth centuries about twenty-four music and instrument dealers were active in America. The first of these businesses began in Boston in 1716, others were initially established in Philadelphia and New York in 1759. The majority of their music and instruments were imported from London although some items were made in colonial America. Although a number of American instrument makers were active during the early nineteenth century many instruments continued to be imported from London.

\section{Publishers as Dealers and Makers of Musical Instruments, 1793-1830}

When publishing in America began on a regular basis in 1793, the majority of publishers included imported musical instruments in their stores in addition to sacred and secular music. For example, Benjamin Carr (1768-1831), one of the earliest Philadelphia publishers, advertised his "Musical Repository" on the title page of "Sweet Lilies of the Valley" by James Hook (1793, appendix no. 1): "Where may be had, all the newest 
Music, reprinted from European Publications, Likewise an Elegant Assortment of Piano Fortes, Guittars, Flutes, Violins and other Musical Articles of Superior Quality."20 Most of these publishers were musicians, teachers, or music engravers in addition to their work as publisher and music seller. A few, such as John Geib and his sons; Riley; Firth \& Hall; and the Klemm brothers, began their businesses as musical instrument makers and afterwards became publishers. This activity may have begun as a natural result of expanding their businesses. Many instrument makers would also have yielded to demand by displaying music in their shops. In 1793, the piano makers Thomas Dodds and Christian Claus sold "Young's vocal and instrumental musical miscellany" (Philadelphia: John Young). This sixty-three-page song collection was published between 1793 and 1795 in eight numbers. According to the imprint it could be purchased at the composer's address, from the publisher Matthew Carey, and the firm of Dodds and Claus. ${ }^{21}$ Many extant late eighteenth- and early nineteenth-century musical instruments imported by music dealers were "stenciled" with the dealer's name. That is, they carried the name of the dealer marked on the instrument in some manner even though the instrument was imported and made in England, Germany or France. For example, pianos are inscribed or painted on nameboards; stringed instruments and drums include printed or manuscript paper labels; woodwind instruments have a name stamped into the wood; and brass instruments include an engraved name. By studying these instruments it is sometimes possible to identify characteristics of construction which suggest a country of origin, style of construction, or the hand of a specific maker. In several cases, it is uncertain if an instrument was actually made in America. Identification is hampered by the fact that eighteenth- and early nineteenth-century instruments were very often modeled after English or German instruments of the same period. Nonetheless, an important activity of the music trades, which has not been investigated in detail, is to determine the 
extent of musical instrument importation and making among publishers in America. The following discussion includes only publishers who are known to have sold instruments having their firm's name on the instrument, or to have had a business arrangement with an American maker to sell his instruments.

\section{$\underline{\text { Hewitt }}$}

James Hewitt (1770-1827) was a conductor, composer, and music publisher. He lived in New York from 1792 to 1811 where he was a conductor and music arranger and a composer of many ballad operas. During this time, Hewitt operated a "musical repository" where he gave lessons and sold musical instruments and music composed by himself and others. There is evidence to indicate that Hewitt sold pianos (or at least was intending to sell them) by at least one American maker, Benjamin Crehore (1765-1831) of Milton, Massachusetts. In a letter from Hewitt to Crehore dated November 23, 1797, Hewitt writes, "I should be very glad to have some of your pianofortes on commission and to supply you with whatever I have in my store upon terms which shall be agreed upon." A second letter addressed to Crehore two days later by B. Dangel of New York states that he "spoke to Mr. Hewitt, our leader, who keeps a music store here about forte piano strings, which you want. His character is that of a real gentleman. Here is a letter to you for him. I described your knowledge in making musical instruments, particularly forte pianos." 22

Crehore is believed to be the first instrument maker in New England to build pianos and one of the first to make bass viols. His earliest instrument, a bass viol, dates from 1788 and his pianos were constructed from about 1795 to about 1810.23 According to Spillane, Crehore exhibited a harpsichord in 1792 , with improvements modelled after 
the mechanism of the piano. ${ }^{24}$ Crehore subsequently supplied pianos to two other publishers in New York and Boston.

Hewitt continued to sell pianos as well as a number of other instruments in his music store as indicated at the conclusion of a notice of new music in the New York Daily Advertiser of August 6, 1801 :

also . . piano fortes, grand and small, with or without additional keys, warranted to stand the climate, violins, clarinets, oboes, bassoons, horns, violincellos, flutes of every description, tenors, tamborins, field drums, strings for the harp, violin, violincells, double bass piano forte, \&c. and every article in the musical line on the lowest terms. Two capital organs, suitable for church or chapple, to be sold cheap. ${ }^{25}$

From 1811 to 1816 the Hewitt family moved to Boston where James pursued the same musical interests as in New York. The family returned to New York but from 1820 to 1825 James traveled often between Boston, New York and several southern cities, particularly Charleston, and Augusta, Georgia. He died in 1827. His son John Hill Hewitt (1801-1890) became a composer, playwright, poet, and journalist. James Lang Hewitt (1803-1853) became a music publisher (unconnected with his father's firm) in Boston from 1825.26

\section{Von Hagen}

Peter Albrecht von Hagen (1755-1803) and his wife Elizabeth Joanetta Catherine von Hagen (1750-1809 or 1810) immigrated to America in 1774. They settled initially in Charleston and by 1789 were in New York, where they were active as performers, teachers, concert managers, and instrument dealers. In the November 20, 1789, issue of the Daily Advertiser, von Hagen inserted the program of his benefit concert at the City 
Assembly to be held on December 1st. On this program von Hagen stated that he sold a variety of instruments and that he would teach at "6 dollars a month (or 12 lessons) and one pound entrance" any of the following: violin, harpsichord, tenor [viola], violoncello, German flute, hautboy, clarinet, bassoon, singing, and the nail violin. ${ }^{27}$ In 1796 the family moved to Boston where von Hagen, his wife, Elizabeth, and son Peter, Jr., taught fortepiano, harpsichord, organ, singing, and music theory. In 1798 Peter, Sr., established his business and became one of the most important music dealers and publishers issuing patriotic songs, selections from ballad operas, and his own compositions. In 1798 the firm of P. A. von Hagen Jr. \& Co. entered into a partnership with Benjamin Crehore.

In May 1798, Crehore became a partner of the Hagen's firm "for the purpose of importing from London instruments of the first quality and the best makers. Also from Amsterdam by the justly celebrated Meyer formerly of the City of London." Their association, however, lasted only until June 1799 when it was "dissolved by mutual consent."28 While Crehore's instruments cannot be traced to the von Hagen's shop, one piano survives by Meincke Meyer and Pieter Meyer of Amsterdam dated 1798 which, according to its label, was imported by the von Hagens. A label on the left keywell of this piano reads: "P. A. Von Hagen junr. \& Co. / Have for Sale at their / MUSICAL MAGAZINE / No. 55 Marlboro Street, BOSTON, / Warranted Imported Grand \& Portable Grand / PIANO FORTES. / A great variety of Single Songs \& Lessons. All kinds of Musical Instruments, Strings, \&c." Because this instrument sits on a Hepplewhite stand not typical of other Meyer pianos it is thought it was probably made by Benjamin Crehore. This piano by the Meyers is one of the few extant instruments in the United States and its stand is the only one that may be identified with Crehore. ${ }^{29}$ Pianos continued to be sold at the von Hagens firm which, according to a notice in the Columbian Centinel for August 7, 1799, was called the "Warranted Imported Pianoforte Warehouse." 
That year the company moved to 55 Marlboro Street and later in the year to 3 Cornhill. Until 1802 the von Hagens maintained a separate piano warehouse at 4 old Massachusetts Bank. ${ }^{30}$ The elder von Hagen died in 1803 and the stock of the store was sold in 1804 to Gottlieb Graupner.

\section{Graupner}

The German musician and teacher, Gottlieb Graupner (1767-1836), arrived in Charleston, South Carolina, in 1795 via London and Prince Edward Island, Canada. He married Catherine Comerford Hillier, a singer who was traveling through Charleston with a theater group from Boston. By 1797 Graupner and his wife settled in Boston and were engaged at the Federal Street Theatre. In 1801, Graupner established the American Conservatorio with Francis Mallet and Filippo Trajetta which soon became involved in the selling, hiring, and printing of music. ${ }^{31}$ The company, under the name of Mallet $\&$ Graupner, also carried on a brisk musical instrument dealership, emphasizing pianos made by Benjamin Crehore in an advertisement in the Boston Gazette of November 23, 1801 :

\section{MESSRS. MALLET AND GRAUPNER}

Respectfully acquaint the Public that [they] have lately received from London several Musical Instruments, of the latest and most improved workmanship, which are now ready for sale at the Conservatory Hall, Rowe's Lane, and consist of Grand Piano Fortes, Harpsichords, small do. double action, best English Guitars, \&c. Also, for sale at the above place, a large assortment of American Piano Fortes, manufactured by $\mathrm{Mr}$. Benjamin Crehore, whose genius and experience, cannot fail of producing as correct and elegant work, in this line, as any imported from abroad; and it is hoped will insure him the patronage and encouragement of his fellow citizens. His instruments will be warranted by Messrs. M. \& G. for six 
months. The Hall will be opened for the sale of Instruments from 12 till 2 o'clock. ${ }^{32}$

Graupner continued to operate the firm alone after 1801, and during the early decades of the nineteenth century he became Boston's leading music publisher and dealer, selling music on consignment from other dealers and engraving and printing music and instrument material himself. Crehore may have continued to supply him with pianos, ${ }^{33}$ but Graupner received instruments from other dealers and maintained reciprocal agreements to sell their music and merchandise. Graupner's commission and account books preserved in the Brown University library provide important evidence regarding the ordering of musical merchandise from London. Between 1806 and 1817 Graupner recorded many extremely large orders of music and musical merchandise purchased from or through the firm of Clementi in London. The first such transaction, which is typical, records the purchase of diverse merchandise in the amount of $£ 1164 \mathrm{~s} 3 \mathrm{~d}$, a large sum for those days. Items ordered included: pianofortes, clarinets, violins, Kent bugles, etc., and music strings, mutes, cases, tuning forks and hammers, bridges, and music. ${ }^{34}$

The following advertisement is found in the Columbian Centinel for Wednesday, October 28,1812 , for a larger variety of merchandise:

\section{Piano Fortes}

G. Graupner respectfully informs his friends, and the public, that he has received by the Cato, from London, and will be read for sale in a few days-

An invoice of musical instruments, viz.--Upright and Square Piano Fortes, of the latest improvements, clarionets, Horns, Bassoons, with Trumpet Tops; Cymballs, Violin, Piano, and Guitar Strings; Clarionets and Bassoon Reeds; Likewise a variety of New Musick, the whole of which he will dispose of at a small advance.

He has also on hand--an elegant ORGAN, made in London, sufficiently large for a Place of Worship - price $\$ 1,400$. 
G. G. begs leave, at the same time, to draw the attention of the admirers of Music to his new instrument

THE GLASSICHORD

which for the extraordinary sweetness of its melody is particularly pleasing. Instructions for playing on it, are prepared and affixed to each instrument, and may be had at his store, No. 6, Franklin Street. ${ }^{35}$

Many square and grand pianos made by Clementi are found in several American collections as well as flutes, clarinets, and keyed (or Kent) bugles signed Clementi \& Co. The wind instruments, however, were probably made for Clementi by other English makers such as Thomas Proswe.

Blake

The English music engraver and publisher George E. Blake (1775?-1871) immigrated to the US before 1793 and in 1794 began teaching flute and clarinet in Philadelphia. In 1802 he acquired the piano manufactory of John I. Hawkins and soon after began to publish and operate a circulating music library. ${ }^{36}$ Blake also taught the flageolet as evidenced by an advertisement on his publication of Instructions for the patent flagelet and English and French flagelets (ca. 1807). ${ }^{37}$ He was America's most prolific music publisher from about 1810 to 1830 . Blake advertised himself as a "Piano-Forte Maker" on an engraving (which has been dated from 1817 to 1824), illustrating a woman playing an upright piano. ${ }^{38}$ During the 1820 s Blake's store is advertised on his sheet music as "Piano Forte and Music Store." Unfortunately, pianos of Blake's manufacture have not been identified in public or private collections; he probably sold instruments made by English or other American makers. His retail business must have included a wide variety of instruments as shown by a note affixed to the imprint of Blake's Preceptor for the Spanish Guitar and Lyre (c. 1825): "A great variety of Spanish and English guitars, Harp 
Lutes, Harp Guitars, \&c. \&c. for sale as above." 39 Additional instruments sold by Blake include a keyless flageolet; a one-key flageolet, an eight-key flute, and a twelve-key clarinet illustrated on a paper label marked "Sold at Blake's Music Store No. 13 So. Fifth St. Philadelphia," affixed to John Parry's "Mama is so very particular" (Boston: Oliver Ditson, circa 1842, in the Huntington Library). After Blake's death an auction of his stock of music plates, sheet music, musical instruments, and other materials was held on May 22, 1871. The auction catalog lists dozens of instruments including: flutes, fifes, flageolets, accordions, clarinets, French horns, keyed bugles, cornets, trumpets, trombones, bass horns, ophicleides, serpent, bassoons, harps, guitars, mandolins, cellos, violins, and many other accessories. ${ }^{40}$ The writer is aware of only one instrument marked "G. E. Blake / Phila.," an eight-key clarinet (of English origin) in the collection of Dr. Jack Coleman of Tarzana, California. No doubt, there are other examples of instruments extant with Blake's mark.

$\underline{\text { Geib }}$

John Lawrence [Johann Lorenz] Geib (1744-1819) made organs and probably pianos in Germany and by 1779 emigrated to London. On July 24, 1797, he sailed with his wife and seven children to New York and soon thereafter took his twin sons John, Jr. (1780-1821) and Adam (1780-1849), and possibly his third son George (1782-1842), into his business, renaming it John Geib \& Co. Geib became the leading maker in American organ building at this time. In the Spectator for March 19, 1800, the Geibs advertised their work on an organ for Christ Church in New York and listed additional instruments:

Church Organs, to any value above a thousand dols.; chamber Organs, also, church and Chamber Organs, to play with barrels and fingers, which will be very convenient and can be used by persons who have no 
knowledge of music; Organized Piano Fortes; Grand and Patent small Piano Fortes; Common Action ditto [i.e., single action]; Pedal Harps, etc. ${ }^{41}$

From about 1804 until about 1814 the firm was known as John Geib \& Son and from 1814 their activities included music publishing. After the elder Geib's retirement the firm was called, for a time, John Geib Jun. In 1818 the twins John, Jr., and Adam were joined by another brother, William (1793-1860); he remained with the business until 1827 and built independently from about 1831. Until 1821, when John, Jr., died, Geib pianos were marked "J. A. Geib" or "J. A. \& W. Geib." Adam continued the firm with his brother William, as "A. \& W. Geib," from 1821 or 1822 until about 1827, but in 1829 took a new partner, his son-in-law Daniel Walker, who remained with him until 1843.

A number of pianos made by members of the Geib family are preserved in several American public and private collections. ${ }^{42}$ However, there was a constant demand for foreign-made musical instruments, particularly pianos made in London and Paris, as can be seen in the following advertisements of John \& Adam Geib \& Co. dated from 1816 and about 1818:

A large assortment of grand and small Piano fortes, made by Geib, of NewYork, and Broadwood, Astor, Clementi, and others of London. ALSO, Organs, Harps, violins, Flutes, Clarinets, Flageolets, Bassoons, Drums and Fifes, and all that appertains to the Music Business. Music, Foreign, and of their own publication, and the best Roman Violin Strings. ${ }^{43}$

J. A. \& W. GEIB respectfully inform the inhabitants of $N E W=Y O R K$, that they have constantly on hand, at their PIANO=FORTE WAREHOUSE, and WHOLESALE, and RETAIL MUSIC STORE, No. 23 Maiden Lane; a large and handsome assortment of Music, and Musical Instruments. As they import direct from London, Paris, and Germany, they have it in their power to deal in wholesale, upon very liberal terms. They receive PIANO FORTES of every description, by the quantity from the Manufactories, of 
Broadwood and Sons; Clementi, and Co.; Astor, and Horwood; and Stodart, and others of London; and Erard of Paris: in addition to which the PIANO FORTES of their own Manufacture -- in this City; which are well known for their excellent tone and workmanship, and unequal'd durability in Southern Climates. PEDAL HARPS, of Erard, Stumpf and others, Guitars, Violins, by the box, and single; They continue to manufacture ORGANS, of every kind; some of which, the modern Organized Piano Forte, are perhaps superior in elegance, to any piece of musical furniture yet constructed. The newest and best music constantly on hand, by the quantity, or piece. Piano Fortes hired out by the month, and Piano Fortes, and other Instruments repaired, tuned, and stored. Also, music Engraved, and Printed in the handsomest style. ${ }^{44}$

The Geib's firm was also active in repairing, tuning and storing keyboard instruments, as well as engraving and printing music. Flutes are preserved in collections stamped "Geib," "J. A. \& W. Geib," "W. Geib," and "Geib \& Walker," but were probably imported from an English maker or made for them by a New York woodwind maker. ${ }^{45}$

$\underline{\text { Riley }}$

Edward Riley (1769-1829) was an engraver and music publisher in England from 1795 to 1803 before immigrating to the United States and settling in New York in 1805 or 1806. Riley taught piano, singing, German flute, and flageolet; was a music engraver for various New York publishers; tuned keyboard instruments; repaired instruments; and was a maker of flutes, fifes, clarinets, and flageolets. ${ }^{46} \mathrm{He}$ began his publishing firm in New York in 1811 and became one of the most active New York publishers. By 1813 Riley was also making drums when he advertised the following in the National Intelligencer (Washington, D.C.) of December 14, 1813, ". . informs the gentlemen of the Army he 
manufactures treble, tenor \& bass drums of the best quality. Orders recieved at his store, No. 23 Chatham St., New York."47

The extent of the instruments Riley subsequently sold in his shop is indicated by a label in a cello (circa 1825) made for him, in the private collection of Frederick R. Selch, New York:

E. Riley. Musical instrument maker, music engraver, printer and publisher, Chatham Street, New York. Violins- Tenor, Violoncellos, English and Spanish Guitars, German flutes with one, four, five, six and eight keys, Single and double flageolets, Clarionets-B's, C's, F's and E's, Bassoons, Violin strings, Guitar strings, Bassoon, Hautboys and Clarionet reeds, Fifes B's, C's and D's, Bass drums, Tenor drums, Treble and side drums, Tambourines and French horns, Children's drums, Bugles with and without keys, trumpets, Drumsticks and belts, Violin bows and etc., etc., etc., Bridges, Pegs, mutes, tuning forks and piano hammers, Music paper and books - music board, Musical instruments of all kinds tuned and repaired. The Pianoforte, English and Spanish Guitar, violin, violoncello, clarionet, Single and Double... [indecipherable]. ${ }^{48}$

By the 1820 s Riley found enough demand in New York to stock a variety of instruments including clarinets pitched in B-flat, C, F and E-flat and fifes in B-flat, C and D.

\section{Dubois}

William Dubois (d. 1854?) was working in New York from 1813 as an instrument importer and dealer. He bought the plate stock of John Paff, who had continued on alone after his brother Michael's retirement in 1810. During the next year or two, Dubois began publishing by re-issuing almost all of Paff's 1811-1817 catalog under his own name. According to Spillane, Dubois "was born in the West Indies, but had handled pianos, as a ship merchant, between [New York] and London . . . he knew nothing practically about 
pianofortes and was not even a musician." 49 Fisher, however, identified Dubois as a French clarinetist, singer, and composer who came to the United States in about 1795. A Mr. Dubois is also listed in several programs as a clarinetist by Sonneck..$^{50}$

An advertisement in the New York Evening Post of July 28, 1817, indicates that Dubois imported pianos from London:

New Instruments and Music just received per Lorenzo, from London, a choice assortment of pianofortes ... elegant round corners with drawers . . . also, a selection of the newest music. ${ }^{51}$

In 1822 Dubois joined the piano maker Adam Stodart as the financial backer of the partnership Dubois \& Stodart. Examples of their square pianos exist in the Smithsonian Institution; Chateau Ramezay, Montreal; the New York State Historical Collection \& the Farmers' Museum, Cooperstown, New York; and Ringwood State Park, Ringwood, New Jersey. The instruments in Cooperstown and Ringwood are signed on the nameboard "William \& Robert Nunns for Dubois \& Stodart," so it must be assumed that some of the instruments sold by Dubois \& Stodart were actually made by the Nunns brothers. ${ }^{52}$ The Nunns brothers established their piano-making company in 1823 and became an extremely successful New York firm.

\section{Bacon}

Allyn Bacon (1789-1864) served as an apprentice to the musical instrument maker George Catlin (17.77 or 1778-1852) in Hartford, Connecticut, about 1812. In 1814, he established his own shop as a maker of organs and publisher of music in Philadelphia. Eventually, Bacon made keyboard instruments, stringed instruments, and woodwind instruments. From 1815 to 1817 he worked again with Catlin; in 1820 he entered into 
partnership with the engraver Abraham Hart, who was succeeded by the flute maker Thomas Weygandt in 1833. Extant instruments from this firm are signed "Bacon \& Hart" and "Bacon \& Weygandt" and include flutes and a double flageolet. ${ }^{53}$

\section{Parker}

John Rowe Parker (1777-1844) was a Boston merchant and importer of various goods from London beginning in 1802. Subsequently, he lived in New London, Connecticut, for about three years where he operated as a merchant. Here, he imported pianos from William Goodhue of New York and on February 16, 1814, advertised in the Connecticut Gazette:

\section{An Organ for Saie}

A good English made organ. 6 stops: Stop Diapason, Open Diapason, Principal, flute, 12th, 15th, well calculated for place of public worship. John R. Parker, New London, Federal St., Feb. 7, 1814. ${ }^{54}$

In April of 1817, Parker moved to the Franklin Music Warehouse at 6 Milk Street in Boston where he was in partnership with Gottlieb Graupner for four months. During 1817 and 1818 Parker purchased a large stock of sheet music and instruments: flutes, clarinets, and fifes from John Geib; flutes from Edward Riley; instructors for flute, bassoon, guitar, and piano from George Willig; and possibly pianos from William Stodart as quoted to him by a dealer Sargeant $\&$ Segar. ${ }^{55}$

Parker edited a periodical entitled The Euterpeiad, Or Musical Intelligencer published by Thomas Badger, Jr., of Boston from April 1, 1820, to March 24, 1821.56 It dealt with musical topics, included musical selections, and advertisements by musical 
instrument makers, dealers and teachers. On the last page of volume one, number one, Parker (as the Franklin Music Warehouse) advertised the following instruments:

Church, Chamber, and Barrel Organs, of all dimensions, and Piano-Fortes. Just imported from Germany, elegant square PIANO FORTES, round corners, with double strings and three Pedals. Also . . . a very elegant Grand Horizontal Piano Forte, with six Pedals. The above being a consignment, will be sold low for cash, to close the sales.

In the third number of volume one Parker added a large stock of instruments and accessories:

Elegant Pedal, AEolian and plain Harps, Harp Lutes, Clarinets, Oboes, Flutes, Fifes, Flagenlets, Picolais and Pitch Pipes. Bassoons, Horns, Clarions or Tenoroons, military B. and C. Bugles, with Crooks, Cymbols, English and Spanish Guitars, Violins, Violas, and Violincellos. Piano Forte, Harp, Guitar, Violin and Violincello Strings, Music Stools, Canterburys, Tuning Forks and hammers, Clarionet, Oboe and Basson Reeds, Mouth Pieces, Bridges, Tail Pieces, hair for Bows, Rosin, \&c.

Parker continued to advertise his stock of instruments and music throughout the majority of Euterpeiad issues.

\section{$\underline{\text { Klemm }}$}

Johann Georg (John George) Klemm (1795-?) and his brother Frederick August Klemm (c. 1795-?) were active in Philadelphia as Klemm \& Brother from about 1819. They imported many types of woodwind and brass instruments from the family firm of Georg and August Klemm of Neukirchen. Klemm \& Brother consistently called itself "importers and dealers" and used the terms "makers" or "manufacturers" sparingly. During the 1820 s the Klemms opened a piano factory and from 1829 until 1832 Alpheus 
Babcock of Boston built pianos for them. About 1823 the Klemms purchased Allyn Bacon's plate stock and began a publishing business that continued for almost sixty years, reissuing almost the entire Bacon catalog under their own name. The business continued under the directorship of both brothers until the 1860s, when John George seems to have retired or died. Frederick and his two sons, John George and Edward Meinel, remained as directors from the 1860 s until 1879.57

During the 1820s woodwind and brass instruments were imported from the family's Neukirchen factory, including: flutes with four to six keys made of boxwood with ivory or bone ferrules; fifes of maple or boxwood and brass ferrules; clarinets with five or six keys of boxwood with bone ferrules; small signal horns (Officer's bugles) in C or Bflat, trumpets in $\mathrm{G}$ or $\mathrm{F}$, with from two to four crooks; keyed bugles, and saxhorns with string-action rotary valves or Berlin piston valves. The saxhorns were probably made by William Seefeldt of Philadelphia after 1857; the maple fifes were probably made in Philadelphia; and the remaining instruments were probably imported from Neukirchen. ${ }^{58}$ Violins with Klemm's label were probably imported instruments from Saxony. ${ }^{59}$ Examples of their instruments are found in many museums and private collections.

\section{Firth, Hall \& Pond}

John Firth (1789-1864) was born in England and came to the US about 1810 to learn how to make flutes and fifes in the shop of Edward Riley. William Hall (1796-1874) was apprenticed to a musical instrument maker in Albany and went to work for Riley in New York about 1812. Firth set up business as an instrument maker and music publisher in New York in 1815 and Hall did so in 1820. In 1820 Firth and Hall formed a partnership at 362 Pearl Street. In 1833 they were joined by Sylvanus Pond (1792-1871) who went to Albany in his youth, engaging in the commercial music business first 
independently and subsequently in partnership with John Meacham. For some reason the firm of Firth, Hall \& Pond was not listed in the New York Commercial Directory again until 1843. As Firth \& Hall the firm advertised as "manuf of pinaforte, with the new patent vibrating overbridge \& importer of all kinds of mus instrs." 60

Several flutes and flageolets are extant with the mark "Firth \& Hall" (1821-1841); clarinets, flutes, and at least one upright piano (in the Metropolitan Museum) are found marked "Firth, Hall \& Pond" (1833-1847). A branch of the latter firm was also opened in Litchfield, Connecticut, from 1839 to 1867 ; Firth, Pond \& Co. operated from 1847 or 1848 to 1863 ; and Firth, Son \& Co. from 1863 to $1867 .{ }^{61}$ Keyed bugles marked "Firth, Hall \& Pond" are preserved in museums (University of Michigan and Henry Ford Museum) and private collections. According to Robb Stewart, a well-known brass expert and restorer, these instruments were very likely imported from England for sale in the US by this company.

\section{Ashton}

John Aston, Jr. (c. 1813-1849) was a music publisher, musical instrument dealer, and umbrella maker in Boston from 1818 to 1844 . He initially took over the music shop of Charles and Elna Hayts and advertised in the New England Palladium of February 28, 1818 , the following:

A general assortment of Flutes-Clarinets-Bassoons-Violins-Bass violsGuitera-Hand organs-Horns-Trumpets-Bugles-Drums-Fifes-CymbalsFlageolets \&c.

A large collection of the most approved music for the Piano-ForteInstruction books for all instruments.

Silk and cotton umbrellas and Parasols, of their make and imported. A number of first rate chamber organs finishing. 
Pianofortes and organs repaired.

N.B. Church organs made and warranted to be equal in every respect to the English and much cheaper.

A few tons of Ebony of superior quality.

Journeyman Cabinet makers wanted. ${ }^{62}$

Ashton's publishing firm began in 1820 and after 1834 he established a partnership with Eben $\mathrm{H}$. Wade. An advertisement of April 1, 1820 in the first issue of volume one of The Euterpeiad: Or, Musical Intelligencer listed the following:

John Ashton, has for Sale wholesale and retail, No. 18, Marlboro'-Street. LONDON E Flat and C Bugle Horns, with Crooks, Brass and CopperTrumpets and Horns. Bass Drums, from $\$ 15$ to $\$ 24$ each; Military Drums ornamented; Ebony and Boxwood Fifes, Callender's make; Astors C B and E Flat Clarionets, with shake Keyes, Tenor Viols, Triangles and Flageolets; London made Flutes, from 1 to 6 keys.

By October 1820 Ashton moved his shop two doors down to No. 20 Marlborough Street. In volume one, number 30 of The Euterpeiad, he advertised that he had received by the "London Packet and other recent arrivals, a large and well assortment of Musical

Instruments ... part of which are as follows:

Bass Viols (patent screws)

E flat Brass and Copper Bugle Horns, 14 and 6 Keyed Flutes, (patent)

Flageolets, with ivory cisterns, (patent)

B C E and F Clarionets, (Ashton's make) warranted to be of superior quality.

Violins, Bass Viols and double Bass, Strings, warranted Real Roman Fresh."

Ashton continued to advertise the same instruments in a few additional numbers of The Euterpeiad for 1820. In an advertisement in the New Hampshire Statesman and 
Concord Register of November 3, 1827, Ashton advertised as an importer of keyed bugles, umbrellas, billiard balls, whalebone stays, and Hippopotamus teeth. ${ }^{63}$ Instruments found with his stamp (an eagle looking right over wings downswept) include a flute, a clarinet (Henry Ford Museum, Dearborn, Michigan), and a drum with a painted eagle. ${ }^{64}$ According to Eliason, Ashton's instruments may have been made by Graves \& Co. in Winchester, New Hampshire. ${ }^{65}$

\section{$\underline{\text { Conclusion }}$}

The music trades in America began in the eighteenth century with a few dealers of music and musical instruments in Boston, Philadelphia, New York, and a few smaller cities. As the population grew in these cities interest in music increased and more dealers were established. The majority of music was imported to America from London and the majority of instruments were also imported. During the early nineteenth century many instruments were made in the United States, although the evidence presented here has shown that a large number continued to be imported from London. Music and musical instruments were sold by general merchants, book store dealers, and music store dealers. With the establishment of a publishing industry in 1793 the number of dealers increased who also offered instruments in their shops. Of the twelve dealers discussed who sold instruments with their firm name on the instrument, or who sold instruments by American makers, five were active in New York, four in Boston, and three in Philadelphia.

The development of the music trades was also tied to the rise of American culture and its institutions. Theaters and pleasure gardens popularized music and American education often emphasized studying music, particularly for young women. Furthermore, the inclusion of a piano in the home was a symbol of social attainment. By 1826, the educator Lowell Mason arrived in Boston and established a program of systematic music 
instruction in the public schools. He published hymns and songbooks and emphasized the works of European composers. ${ }^{66}$ The music trades in America grew in proportion with this expanding interest in music.

Notes

${ }^{1} \mathrm{~A}$ discussion of the importance of the piano in American society is found in Arthur Loesser, Men, Women and Pianos: A Social History (New York: Simon and Schuster, 1954). See also the penetrating and detailed study of music in English eighteenth-century life in Richard Leppert, Music and Image: Domesticity, Ideology and Socio-Cultural Formation in Eighteenth-Century England (Cambridge: Cambridge University Press, 1988).

2Barbara Lambert, "Appendix C: Music Masters in Colonial Boston," Music in Colonial Massachusetts 1630-1820 ed. by B. Lambert (II: Music in Homes and in Churches; Boston: The Colonial Society of Massachusetts, 1985), 988.

${ }^{3}$ Sinclair Hitchings, "The Musical Pursuits of William Price and Thomas Johnston," Music in Colonial Massachusetts 1630-1820 (II: Music in Homes and in Churches; Boston: The Colonial Society of Massachusetts, 1985), Fig. 342, p. 637.

4Ibid., Fig. 343, p. 637.

${ }^{5}$ George Francis Dow, The Arts \& Crafts in New England 1704-1775 (Topsfield, Massachusetts: The Wayside Press, 1927), 301. The trade cards of Lewis and Gilbert Deblois are reproduced by Cynthia Adams Hoover in "Secular Music in Early Massachusetts," Music in Colonial Massachusetts 1630-1820 (II: Music in Homes and in Churches; Boston: The Colonial Society of Massachusetts, 1985), Fig. 425, 802; and Fig. 434,815 (erroneously dated as 1737 in the caption).

${ }^{6}$ William Arms Fisher, Notes on Music in Old Boston (Boston: Oliver Ditson Company, 1918), 21-22.

7Ibid., p. 22. Fisher reproduces an advertisement for music at Battelle's book store in the Massachusetts Centinel of November 6, 1784.

${ }^{8} \mathrm{~A}$ photograph of this drum is reproduced by Hoover, 721.

${ }^{9} \mathrm{~A}$ photograph of Crossman's drum and its interior label is given by Lambert in "Social Music In Colonial Boston," Music in Colonial Massachusetts 1630-1820 (II: Music in Homes and in Churches; Boston: The Colonial Society of Massachusetts, 1985), 497. Clemm's contributions, a description, and photographs of his spinet are found in Laurence 
Libin, American Musical Instruments in The Metropolitan Museum of Art (New York: W.W. Norton \& Co., 1985), Figs. 190-91, 156-58.

${ }^{10}$ See Jo Ann Taricani, "Music in Colonial Philadelphia: Some New Documents," Musical Quarterly 65 (April 1979): 193. German flutes are transverse flutes while common flutes are recorders.

${ }^{11}$ Taricani, 194. Kitts are small, four-stringed fiddles made either in the shape of a violin, viol, or guitar, or pear-shaped resembling a narrow boat. The psalter or psaltery is a plucked zither made in a variety of shapes, and the monochord is a single-string zither with a movable bridge used as a musical instrument or to demonstrate mathematical divisions of the scale.

12Taricani, 192-3, 197-8, n. 49.

${ }^{13}$ Rita S. Gottesman, The Arts and Crafts in New York 1726-1776 (New York: New York Historical Society, 1936; reprint ed., New York: Da Capo, 1970), 371-72.

14Hoover, 787-88.

${ }^{15}$ Gottesman, 372. In an advertisement in The New-York Gazette of February 1, 1762 , Harrison is mentioned as organist of Trinity Church and as a dealer in all kinds of musical instruments. See Oscar George Sonneck, Early Concert-Life in America (1731-1800) (Leipzig: Breitkopf \& Härtel, 1907), 169, n. 5.

${ }^{16}$ Gottesman, 367-68. Eliason suggested that Wolhaupter's son David continued to work in New York until the revolution; however, on the basis of a similar list of instruments, Groce suggested that Wolhaupter advertised in 1770 and 1775 as David Wolhaupter. See Robert Eliason, "Flute Makers of Early America, part 1," Woodwind World-Brass \& Percussion 15, no. 1 (January 1976): 28; Nancy Groce, Musical Instrument Makers of New York: A Directory of Eighteenth- and Nineteenth-Century Urban Craftsmen (Stuyvesant, N. Y.: Pendragon Press, 1991), 174-75.

${ }^{17}$ See Gottesman, 365-73; Hoover, 792.

${ }^{18}$ Hoover, Fig. 417, 793. Juhan was also active in Halifax, Nova Scotia, during 1768; in Charleston, South Carolina, from 1771 to 1772; Philadelphia from 1783 to 1786 , Portsmouth, Virginia, during 1786; Petersburg, Virginia, during 1787; Richmond, Virginia, from 1792 to 1793; and Petersburg, Virginia, during 1797. See Lambert, "Appendix C: Music Masters in Colonial Boston," 1079-94.

${ }^{19}$ Frank Kidson and H. G. Farmer, "John Jacob Astor," New Grove Dictionary of American Music, ed. S. Sadie (New York: Macmillan, 1986), 1: 87. 
20"Sweet Lilies of the Valley" is preserved in the Huntington's collection described in the appendix no. 1. Benjamin Carr's father, Joseph (1739-1819) immigrated to Baltimore and established a publishing firm in 1794, where he sold keyboard instruments and guitars. See W. Thomas Marrocco and Mark Jacobs, "Carr," The New Grove Dictionary of American Music (New York: MacMillan, 1986), 1: 360.

${ }^{21}$ See Oscar George Theodore Sonneck and William Treat Upton, A Bibliography of Early Secular American Music [18th Century] (Washington: The Library of Congress, 1945), 484. After 1793 the partnership of Dodds and Claus ended but both individuals continued as musical instrument makers. See Groce, 31-2, 43-44. For a description of the only extant piano made by Dodds \& Claus, see Laurence Libin, American Musical Instruments in the Metropolitan Museum of Art (New York: W. W. Norton, 1985), 162-63.

${ }^{22}$ Darcy Kuronen, "The Musical Instruments of Benjamin Crehore," Journal of the Museum of Fine Arts, Boston 4 (1992): 54.

${ }^{23} \mathrm{An}$ overview of Crehore's extant instruments is given by Kuronen, 52-79.

${ }^{24}$ Spillane credited Crehore as a maker of guitars, drums, and flutes as early as 1791 . However, Spillane did not cite a newspaper advertisement or any other evidence to substantiate his statement, and it seems likely that Crehore could have procured these instruments from another source and simply offered them for sale in his shop. See Daniel Spillane, History of the American Pianoforte (New York: The Author, 1890; reprint ed., New York: Da Capo, 1969), 51; repeated by H. Earle Johnson, Musical Interludes in Boston 1795-1830 (New York: Columbia University Press, 1943), 270. Two additional authors who state that Crehore was a harpsichord maker are: Christine Merrick Ayars, Contributions to the Art of Music in America by the Music Industries of Boston 1640 to 1936 (New York, 1937; reprint ed. New York: Johnson Reprint Co., 1969), 104; and Richard J. Wolfe, Early American Music Engraving and Printing (Urbana: University of Illinois Press, 1980), 59.

${ }^{25}$ See Wolfe, 70, n. 2. The "additional keys" of the pianos referred to an additional onehalf octave in the treble range added from $\mathrm{f}^{3}$ to $\mathrm{c}^{4}$, often found on square pianos made by firms such as the Clementi company.

${ }^{26}$ See John W. Wagner, "Hewitt," The New Grove Dictionary of American Music, 1: 380 81.

${ }^{27}$ See Sonneck, 226. The nail violin consists of a circular, flat wooden resonator with a set of nails or iron pins driven into its sides. It is held in the left hand by a handhold underneath and bowed with a violin bow; the shorter the nail, the higher the pitch. 
${ }^{28}$ Columbian Centinel, July 3, 1799 quoted by Johnson, 269-70. Hoover, 792, mistakenly states that the partnership of Crehore with the von Hagens was announced in the Columbian Centinel for July 3,1799 , the issue in which their partnership was announced as being dissolved.

${ }^{29}$ This instrument is in the collection of Sheridan Germann of New York City.

Photographs of the piano on its stand and its label are included by Hoover, Fig. 418a-b, 794. See also Clinkscale, 199-202. Spillane erroneously stated that Crehore was in partnership with Peter von Hagen Jr. from 1801 to 1807, see Spillane, 52 and Ayars, 103.

${ }^{30}$ See Johnson, 270-71; Ayars, 8.

31Douglas A. Lee, "Graupner, (Johann Christian) Gottlieb," The New Grove Dictionary of American Music, 1: 279.

32Johnson, 272.

${ }^{33} \mathrm{~A}$ recent accounting of Crehore's extant pianos lists six instruments. See Martha Novak Clinkscale, Makers of the Piano 1700-1820 (Oxford: Oxford University Press, 1993), 78-

79. For another discussion of Crehore's activities and one of his pianos see Libin, 164-66.

${ }^{34}$ Wolfe, 223-24.

${ }^{35}$ Nancy Gamble Pressley, "Winterthur Museum's Early American Keyboard and Music Collections: An Example of Museum Resources in Higher Education" (Ph.D. diss., Southern Illinois University at Carbondale, 1982), 24. Bassoons with "trumpet Tops" referred to instruments with an optional wooden or metal bell. Graupner's glassichord may have been similar to a French instrument named "glassschord" by Benjamin Franklin in or by 1785 . It consisted of a series of glass bars laid horizontally on thick cloth strips and stuck from above by wooden cloth-covered hammers controlled by a keyboard. The compass was three octaves from $c^{\prime}$ to $c^{3}$ and dampers were lacking. See Sibyl Marcuse, Musical Instruments: A Comprehensive Dictionary (New York: Doubleday \& Company, 1964), 209.

${ }^{36}$ D. W. Krummel, "Blake, George E.," The New Grove Dictionary of American Music, 1: 229-30.

${ }^{37}$ Richard J. Wolfe, Secular Music in America, 1801-1825; A Bibliography (New York: New York Public Library, 1964), 1: 80, no. 853.

38Illustrated by Wendy A. Cooper in Classical Taste in America 1800-1840 (New York: Abbeville Press, 1993), 264. 
${ }^{39}$ Wolfe, Early American Music Engraving and Printing, 70, n. 2. The English guitar is a form of cittern having two single metal strings and four pairs of metal strings. The Spanish guitar is a common guitar with four gut strings.

${ }^{40} \mathrm{Catalogue}$ of the large and valuable stock of music plates, sheet music, musical instruments, material, \&\& c., being the entire stock of the late George E. Blake (Philadelphia: M. Thomas \& Sons, [1871]), 49-53.

${ }^{41}$ See Barbara Owen, W. Thomas Marrocco, and Mark Jacobs, "Geib," The New Grove Dictionary of American Music, 1: 136; Clinkscale, 117. The "chamber organs, to play with barrels and fingers" referred to barrel organs having a crank which operates a barrel and bellows which supplies air blown through small organ pipes. "Organized" pianofortes were instruments which combined pianos and a pipe organ sometimes called "claviorgans." "Patent small" pianofortes were square pianos built in a rectangular case.

${ }^{42}$ Clinkscale, 117, 119-120, located square pianos marked "John Geib \& Son," "John Geib," "John Geib Jun," "J. A. \& W. Geib," and "A. \& W. Geib." The writer has seen a square piano marked "W. Geib." For an informative description and photographs of two Geib pianos at the Metropolitan Museum, see Libin, 169-74.

${ }^{43}$ Libin, Fig. 207, 172.

${ }^{44}$ Advertisement reproduced by Wolfe in Fig. $6 \mathrm{~b}$.

${ }^{45}$ Lyndesay G. Langwill, An Index of Musical Wind-Instrument Makers, 6th ed. (Edinburgh: The Author, 1980), 57.

${ }^{46}$ Examples of Riley's woodwinds are found in the Miller Collection at the Library of Congress, the Greenfield Village and Henry Ford Museum, Metropolitan Museum, as well as several private collections. Two flutes in the Ford Museum are described and photographed by Robert E. Eliason in "Flute Makers of Early America," Woodwind World-Brass \& Percussion 15, no. 2 (March: 1976): 24, 26.

${ }^{47}$ Bruce S. Bazelon and William F. MicGuinn, A Directory of American Military Goods Dealers \& Makers 1785-1915 (n.p.: 1990), 138.

${ }^{48}$ The Art of Music: American Paintings \& Musical Instruments 1770-1910 (Clinton, N. Y.: Fred L. Emerson Gallery, Hamilton College, 1984), 81. One authority has stated that Riley did make cellos; see Thomas James Wenberg, The Violin Makers of the United States (Mt. Hood, Oregon: Mt. Hood Publishing Co., 1986), 247.

${ }^{49}$ Spillane, 108. Turchin stated that Dubois was listed in the New York City directories as a piano manufacturer and music dealer but Groce listed the directory listings for Dubois 
without any specific designation for the years 1813 to 1816 . See Turchin, "William Dubois," The New Grove Dictionary of American Music, 1: 656; and Groce, Musical Instrument Makers of New York, 46.

${ }^{50}$ William Arms Fisher, One Hundred and Fifty Years of Music Publishing in the United States: An Historical Sketch with Special Reference to the Pioneer Publisher, Oliver Ditson Company, Inc. 1783-1933 (Boston: Oliver Ditson Company, 1933; reprint ed., Clair Shores, Michigan: Scholarly Press, 1977), 98; Sonneck, 30, 31, 56, 147-50, 305.

51Pressley, 53.

${ }^{52}$ For a description and photograph of a square piano by Robert \& William Nunns for Du Bois \& Stodart, New York, circa 1825, see Laurence Libin, "19th-century keyboards suffer in New Jersey," Newsletter of the American Musical Instrument Society XXII, no. 1 (February 1993): 4, 6.

${ }^{53}$ See William Waterhouse, The New Langwill Index: A Dictionary of Musical WindInstrument Makers and Inventors (London: Tony Bingham, 1993), 15.

${ }^{54}$ See H. Earle Johnson, "The John Rowe Parker Letters," The Musical Quarterly 62 (January 1976): 74

55 Johnson, "The John Rowe Parker Letters," 76. Stodart's pianos were described as "Plain, with \& without drawers, ornamented square and round corners, $\mathfrak{1 3 3 / 1 2}$ to 46/4/0; $25 \%$ discount." Clinkscale suggests that William Stodart was probably the same person as Adam Stodart who was active from about 1818 and died about 1873. See Makers of the Piano, 289.

56Reprinted with a new introduction by Charles E. Wunderlich (New York: Da Capo Press, 1977).

${ }^{57}$ See Cynthia Hoover, "Klemm \& Brother(s)," The New Grove Dictionary of Musical Instruments, 2: 445-46; and Wolfe, Early American Music Engraving and Printing, 49.

${ }^{58}$ See Lloyd Farrar "A Directory of American Wind Instrument Makers" (unpublished MS). A clarinet by Klemm Brothers, Philadelphia, ca. 1820 is photographed by Hoover, Fig. 439, 820.

${ }^{59}$ Wenberg, 161.

${ }^{60}$ See Robert E. Eliason, "Firth, Hall \& Pond," The New Grove Dictionary of American Music, 2: 130; Groce, 51-53. 
${ }^{61}$ See Waterhouse, 116.

62Johnson, Musical Interludes in Boston, 277.

${ }^{63}$ Ralph T. Dudgeon, The Keyed Bugle (Metuchen, N. J.: The Scarecrow Press, 1993), 61.

${ }^{64}$ Bazelon and McGuinn, 5.

${ }^{65}$ Robert Eliason, "Letters to Marsh \& Chase from Graves \& Company, Musical Instrument Makers," Journal of the American Musical Instrument Society 4 (1978): 50-51. Eliason also suggests that instruments marked "Marsh \& Chase/ Montpellier" were probably made and supplied to this dealer by the Graves firm. In the author's opinion, the woodwinds stamped by the umbrella maker and music publisher Henry $\mathrm{H}$. Prentiss, active in Boston from 1830 to 1860 , were probably also supplied by Graves since they include an eagle with the stamp.

${ }^{66}$ Nancy R. Davison, "The Grand Triumphal Quick-step; or, Sheet Music Covers in America," in Prints in and of America to 1850, ed. John D. Morse (Winterthur Conference Report 1970; Charlottesville: The University of Virginia Press, 1970), 258. 


\title{
CHAPTER FOUR
}

\section{SOME ASPECTS OF SHEET MUSIC IN THE COLLECTION OF THE HUNTINGTON LIBRARY}

\author{
Introduction
}

The collection of sheet music at the Huntington Library includes 551 publications (some of which are in manuscript form) dating from 1793 to 1830 . While this collection is small compared to some libraries on the East Coast and in the Mid-West it does include several rare items and represents all of the major and many of the minor publishers of the period. Rare items were identified in Oscar Sonneck's A Bibliography of Early Secular American Music (18th Century) and Richard Wolfe's three-volume listing Secular Music in America, 1801-1825; a Bibliography. Items in the Huntington Library which were not located by Sonneck and Wolfe are the following: "Emblems of mem'ry are these tears" (Philadelphia: G. Willig, 1798-1804, appendix no. 15); "Twelve little ballads and a favorite lesson" (Philadelphia: G. E. Blake, 1810-14, no. 58); and "The musical magazine" (Boston: G. Graupner, 1802-1803, no. 31), one of the only complete three-volume sets known of this collection.

Five subjects are discussed in this chapter: the change in appearance of the information presented on title pages within the period of the 1790s to 1830; illustrations and lithographs on title pages; the use and identification of optional instruments; the use of additional instruments which supplement the vocal melody line; and the use of metronome indications. Although the last three topics may be considered performance practice questions of a musicological nature, they also impacted decisions made by composers and publishers in printing music. 


\section{Title Pages}

During the late eighteenth and early nineteenth centuries, the information and layout of the text of the title page changed over time and the characteristics within certain decades can be identified. American publishers copied the layout and printing of title pages from English publications. They also bought the stock of publishers who had gone out of business and published the songs under their own imprint. During the late eighteenth century the title page often included the title itself, the singer who performed the song on stage, the composer, the imprint (referring to the place of publication, the publisher, and an address), and the price. Occassionally included were a dedication statement, mention of the date of an important event, and the names and cities of additional dealers who sold the music. After 1800 generally more information appeared on title pages such as an opus number, the arranger's name, and a dedication. After 1810 the placement of a song in a numbered series is sometimes indicated and by $1820 \mathrm{a}$ copyright statement begins to be found. ${ }^{1}$

During the late eighteenth century, a common manner in which information was arranged on title pages is shown by the song "O innocence celestial maid" (Example 1, see Appendix no. 7) ${ }^{2}$ published by Benjamin Carr in Philadelphia in 1797 (also available at Carr's New York shop and at John Carr's Baltimore shop). The title is printed by using punches to create large plain capital letters arranged in a straight line. "Sung by Mrs. Warrel" is printed with smaller punches below the title followed by the imprint information and price in parentheses. This song was undoubtedly sung on the stage in a now forgotten theater production probably in Philadelphia or New York. On this particular sheet, a composer is not cited, a practice not uncommon at this time. A few sheets during this time included engravings with the title engraved in a cursive script. Examples in the Huntington's collection include an engraving of John Adams in the title of "Adams and 
liberty" (New York: G. Gilfert, 1798-1801, no. 12); and an American eagle with a shield and sunrays in the title of "The favorite new federal song" (Philadelphia: B. Carr, 1798, no. 10).

A definite change is found in the design and information on most title pages during the first decade of the nineteenth century. A typical example is "O hie thee home Willy" by J. Sanderson (Ex. 2, no. 49) published by James Hewitt in New York in 1809. More information is found on this sheet as four lines (including a curved second line) comprise the title. The fifth line gives the composer, a sixth line identifies the publisher and advertises Hewitt's "Musical Repository \& Library" at No. 59 Maiden Lane. The overall appearance is slightly more ornate and spacious than the earlier title published by Carr. Hewitt's "Library" was a circulating library of sheet music for those customers who decided to borrow the music rather than buy it. According to Krummel, before 1815, the title usually filled a third of the first page; after 1815, the title area expanded to cover half to two-thirds of the page. A few full title pages were produced during the 1790s but this was not common until the 1830s. ${ }^{3}$ Example 3 is from the second decade of the nineteenth century and indicates the use of three different type fonts and engraving. "The beautiful maid" (no. 92 and 93) by John Braham was published in 1817 by William Dubois of New York. The title covered a greater portion of the first page by the use of large type fonts and wide spacing between the lines.

By the 1820 s American publishers imitated the increasingly more ornate style of British title pages. Krummel called sheet music with particularly ornate titles examples from the "age of florid calligraphy."4 An example of this is shown in the "Cadets march for the pianoforte \& flute" by E. R. Hansen (Ex. 4, no. 314) published in Philadelphia by John G. Klemm about 1826. There are nine lines in the title with different size fonts, including a dedication statement and many decorative swirls added throughout. These 
examples are a small sampling of the variety of printing and engraving of title pages in early American sheet music. ${ }^{5}$ Another interesting aspect of title pages is the use of engraving and lithography to create an attractive illustration.

\section{Illustrations}

Engraved illustrations were infrequently found on sheet music published before 1826. Wolfe found slightly more than 220 illustrations dating from 1789 to 1825 , or just

over 2 percent of the total output of all publishers. ${ }^{6}$ Beginning in 1826, lithography began to be used with engraving on title pages and eventually became an important aspect of most title pages.

The earliest sheet music publication including an illustration was John Aitken's 1789 edition of Alexander Reinagle's "The foederal march, as performed in the grand procession in Philadelphia the 4th of July, 1788." Probably to further enhance this patriotic work Aitken engraved into the upper corner of the plate a crude outline of a pole with a liberty cap. ${ }^{7}$ This early attempt was followed by several other ambitious and sophisticated engravings of battle scenes (such as James Hewitt's 1797 "The battle of Trenton," (no. 6) and Benjamin Carr's 1804 or 1805 "The siege of Tripoli"); a Hessian fifer (for George Willig's "Complete tutor for the fife," cira 1805); and the newly completed waterworks at Central Square in Philadelphia (for George Blake's 1807 publication, "Blake's collection of duetts for two flutes, clarinets, or violins"). These illustrations acted as a lure to the potential buyer, suggesting the theme in an imaginative sense. The elements and subjects appearing in these illustrations included: title-page borders and frames; American patriotic themes; comic themes; objects such as birds and flowers; scenes of epic events; dancing themes; martial themes; ornaments, sprays, music books and instruments; and Lafayette. ${ }^{8}$ However, it was only with the introduction of an 
inexpensive method of producing illustrations by lithography in 1826 that illustrations on sheet music became much more common.

Lithographed illustrations on sheet music began to be used in France and Germany during the early nineteenth century and in England by 1820 . This process involved a flat printing surface marked, dampened, and then inked so as to leave ink on only the marked areas for transfer to the paper. ${ }^{9}$ The earliest lithographed illustration on sheet music in America was published in Boston in March 1826 by an unknown publisher. Illustrated by David Claypool Johnston, "The log house" was composed by Anton Philip Heinrich and printed by the Pendleton Brothers. William and John Pendleton were the first commercially successful lithographers in the United States. Their company was active from 1825 to 1836 and employed and trained a number of lithographers, including David Claypool Johnston. ${ }^{10}$ After 1826 a number of lithographers were employed by publishers to produce lithographed illustrations as complete title pages or as a portion of the title page. Lithography continued to be employed in sheet music illustrations throughout the nineteenth century, and in the 1840s chromolithography was used for color illustrations.

Examples of eight lithographed title pages from the Huntington Library's collection illustrates the lithographers choice of pictorial material, and other aspects of production. Example 5, "John Anderson my Jo" (no. 452), arranged by Kozeluch, was published between 1827 and 1835 by Charles Bradlee in Boston. The illustration of an idylliclooking domestic scene showing an elderly couple by a hearth with their cat and bagpipes is certainly appropriate for this "Scotch Air." This lithograph was also produced by the Pendletons and is signed "Pendleton's Lithography, Boston." The actual size of the lithograph takes up about one-third of the title page. Example 6, "Ellen of Lismore" (no. 337), composed by T. Philipps, was published between 1826 and 1831 by Edward Riley in New York. The placement and size of the lithograph of a woman holding on to a young 
child is similar to example 5, but the title is engraved above it. George Endicott and Swett signed the lithograph and were active in New York during the late 1820s or early 1830 s. They are listed in the New York city directories in 1832.11 By 1834 Endicott was working on his own as he is listed as a "Lithographer, Music Dealer and Depository of the Fine Arts."12

From 1827 to 1835 four New York publishers (Edward S. Mesier, Anthony Fleetwood, Anthony Imbert, and Geroge M. Bourne) employed lithography on music as well as illustrations. However, the majority of publishers printed their music from metal plates and often used lithographically produced covers. ${ }^{13}$ Examples 7 and 8 are two slightly different lithographs appearing on the "Rose of Lucerne" (nos. 380-81) by John Barnett published between 1826 and 1832 by Edward Mesier of New York. Both of these lithographs were executed by P. Desobry and are identical except for the length of hair of the young woman holding a box of toys in an idyllic Swiss setting. Desobry was not listed in any of the New York City directories as a lithographer and was probably working with a company listed under another name. Example 9, "The Maltese boatman's song" (no. 404) by L. Devereaux was published between 1826 and 1851 by George Willig of Philadelphia. The theme of this unsigned lithograph is the exotic location of the island of Malta sketched in the distance.

Example 10, "Buy image!" (no. 444) by G. Maddison was published between 1827 and 1832 by Mesier and Bourne in New York. In the foreground a disproportionately large street vendor sells busts and statues in front of the Mesier's and Bourne's shops which are located next to each other. Mesier also advertised himself as a lithographer in this lithograph which he probably executed himself. Example 11, "The invincibles" (no. 371) by J. M. Rycott was published between 1826 and 1832 by Mesier in New York. This charming lithograph is signed by Mesier and the imprint states: "Lithd. and Published by 
E. S. Mesier." It may be depicting a duel between the peg-legged thin man on the right with the rather portly gentleman on the left with the soldier on the right dictating the rules of etiquette concerning dueling. This overall theme of a fortress is somewhat exotic although the seven soldiers in the background may remind one of toy soldiers. Example 12, "When I was a girl of eighteen years old" (no. 423) was published between 1826 and 1851 by George Willig of Philadelphia. The nostalgic song title requires a similar artistic treatment in the unsigned lithograph where an old woman looks upon a young man, and a man with a cigar is petting a dog.

Illustrations are infrequently found on American sheet music before 1825. They began with crude engravings but included several ambitious and sophisticated examples during the early nineteenth century. In 1826 the earliest lithographs were produced by an inexpensive method, and several publishers employed lithographers to illustrate title pages of their music sheets. These lithographs generally depicted the subject matter of the song but in an imaginative manner. Many were meant to be charming illustrations or simply amuse the owner. Contemporary lithographs from England and Europe may also have suggested scenes and subjects for the lithographer to copy. Later during the nineteenth century lithographed title pages became very popular.

\section{Optional melodic instruments}

This section discusses the occasional inclusion of the melody line of a song printed after the version for voice and keyboard on the second or last page of the music sheet. The melody was labelled with a name of an instrument indicating an alternative manner of performance. During the late eighteenth century these parts were most often marked for the flute or guitar, and by the nineteenth century other instruments were specified, such as the violin, clarinet, and flageolet. Identification of the flute and guitar pose special 
problems since these names during the eighteenth century indicated instruments which were not the same as their modern counterparts. A study of these instruments broadens our knowledge of the musical culture of the period and the type of instruments that music publishers and sellers would have sold in their shops. This topic and the two topics that follow have not been discussed, to the writer's knowledge, either in the specialized literature devoted to sheet music and publishing or in the literature concerning performance practice.

Eighteenth-century sheet music or song sheets published in England very often included the melodic line printed on the second page, separated from the song, and marked "for the flute." In his typographical study of English music printing, Krummel states that in song sheets "often a flute part is added in score; and this necessitated the transposition of the melody." 14 The identity of the instrument, however, may not be as evident as Krummel believed and raises the question of why the addition of this part necessitated a transposition of the melody? In answer to the first point, the name "flute" or "common flute" was used in eighteenth-century English song sheets to refer to an alto recorder, ${ }^{15}$ the name "German flute," or "cross flute," referred to the transverse flute, the instrument identified by the name flute today. By the late eighteenth century, the recorder had lost most of its popularity in England and America and it is not absolutely certain for which instruments these parts were written. The designation "flute" in late eighteenthcentury song sheets may still refer to the recorder since Gottlieb Graupner in his "The musical magazine" (1802-03, no. 31) specified both "flute" and "German flute" for different songs in this collection. After 1800 the recorder's popularity had waned and the transverse flute became popular among amateur players. The added parts in song sheets were usually transposed for the flute (or recorder) because the key signature of the original song melody was too awkward to play for amateur musicians. Occassionally, this 
part is not transposed but altered by the addition of ornaments and written an octave higher. An example of this practice is found in The Musical Entertainer (1740), a collection primarily of single song sheets for voice and harpsichord. ${ }^{16} \mathrm{G}$ major and C major were the most frequently written keys for the "flute" which are easily playable on recorder or transverse flute. One song sheet carries the notation "For the German and Common Flute," suggesting that either recorder or transverse could be played; another does not provide a transposed part but notes "Within ye Compass of ye Flute," indicating that the melody was playable as written.

The earliest American sheet music included optional melody parts for a variety of instruments. The Huntington's collection has fourteen examples dating from 1793 to 1817 which include parts for flute, violin, guitar, clarinet, and flageolet (nos. 1, 4, 10, 11, 17, $18,21,28,31,46,81,86,103,133)$. All of these songs include transposed versions of the song melody for one or more instruments. The name "guitar" referred to an instrument now known as the English guitar, a type of cittern popular in England and America from about 1750 to 1810. After this time the six-string Spanish guitar became popular. The English guitar has a flat back and metal strings. Its six courses are tuned to c-e-g-c'-e'-g', the bottom two being single strung and the upper four double, for a total of ten strings. The instrument included twelve brass frets on the fingerboard and often included a special watch-key mechanism for tuning the strings. ${ }^{17}$ Because of its $\mathrm{C}$ major tuning, most of the melodies for "guitar" were transposed to this key (see the table below) and included a limited range of notes. However, the English guitar included holes drilled through the fingerboard between the first four frets for use of a moving-bridge or capo $\underline{\text { tasto }}$, fixed with a wing-nut and a bolt. This facilitated transposition from the $\mathrm{C}$ tuning to several higher pitches to suit the range of the singer being accompanied. ${ }^{18}$ The earliest sheet music in the Huntington's collection which specifies the "Spanish guitar" is "Look 
upon the stars my love" (no. 219) by H. N. Gilles published between 1823 and 1824 by John Cole of Baltimore.

One song, "The favorite new Federal Song" (1798, no. 10) by J. Hopkinson, is marked at the beginning "For the Voice, Piano Forte, Guittar and Clarinett", suggesting that it was appropriate to play on guitar or clarinet. Because this song is written in $\mathrm{C}$ major it could easily be played on the English guitar and clarinet pitched in C. Clarinets at this time were pitched in various tonalities with $\mathrm{C}$ and $\mathrm{B}$-flat instruments being the most popular types. The most important consideration for the publisher of these songs was that the amateur player could easily perform the melody of the songs on their instruments. The table below indicates the instruments suggested by the publishers, the original keys, and the corresponding transposed versions.

\section{TABLE 1}

INSTRUMENTS INCLUDED IN SHEET MUSIC AND THEIR TRANSPOSITIONS

$\begin{array}{ccc}\text { INSTRUMENT } & \text { KEY }^{19} & \text { TRANSPOSED KEY } \\ \text { Flute (or Recorder) } & \text { F, C, E-flat, G, C, A } & \text { G, D, G, D, D, D } \\ \text { Guitar (English Guitar) } & \text { A, F, F, E-flat, D, G, D } & \text { C, C, G, G, C, C, F } \\ \text { Violin } & \text { C, E-flat, F } & \text { D, G, G } \\ \text { Clarinet } & \text { E-flat } & \text { G } \\ \text { German Flute (Transverse } & \text { E-flat, E-flat, d, B-flat, C } & \text { D, F, a, D, D }\end{array}$

Flute

Flageolet

A

D 
Example 13 illustrates the transposed version of "The Farewell" (1807-8, no. 46) "arranged by Haydn" and published by George Blake in Philadelphia. It is somewhat unusual that the melody has been arranged in two parts for two flutes (German flutes) or clarinets, and transposed from D minor to the easier key of A minor.

The preferred accompaning instrument for songs during the late eighteenth and early nineteenth centuries was the popular square piano. However, the harpsichord had not completely vanished from American households as illustrated by the collection entitled "A selection of the most admired ballads" (no. 26) published in Philadelphia by John Morgan in 1801, and "set to the harpsichord \& piano forte." Clearly, here is an example of the optional use of harpsichord or piano. Other examples of keyboard accompaniment in which the player appears to have been given an option to play on the harpsichord or piano include: "The American Musical Miscellany" (1798, no. 9) which includes 111 songs, some with a simple bass line; "Emblems of mem'ry are these tears" (1798-1804, no. 15) which includes several indications of the printed numeral " 8 " (indicating an octave doubling) below the right-hand part; and "Sacred dirges, hymns, and anthems" (1800, no. 22) which includes an instrumental bass part with solo voice.

\section{Additional Instruments}

This section discusses the use of cues, or notes printed in smaller fonts in sheet music and marked with the name of an instrument. There are two distinct practices regarding these cues. The first is the inclusion of smaller notes simply to recall the use of specific instruments in the original theatrical production of the song. In the few examples where these cues are found these notes were not meant to be played on the instruments marked in the score but rather by the piano. The second practice refers to cues which appear in the songs sometimes in the voice part or on a separate stave, and which are 
substantial enough to contribute significantly to the musical texture. However, the use of the instruments marked in the cues remained optional since the song could have been performed without these additional parts.

Cues for several instruments appear in ten songs in the Huntington's collection (nos. 17, 88, 129, 230, 241, 274, 318, 338, 477, 549). The instruments specified are oboe, "corni" (horns), violin, flute, trumpets, tambourine, drums, bugle, clarinet, and cello. These cues are not long extended passages but only a few isolated notes. They were most likely played on the piano when performing the song, and represent the instruments specified in an orchestral score of the song in its original theatrical production. The inclusion of these cues was undoubtedly copied from the earlier publication of cues in the sheet music of English publishers.

An entirely different practice during the early nineteenth century was the specified use of additional or "obligato" instruments which were cued in the sheet music, but were not provided with a separate part. Cues for obligato instruments appear in five songs (nos. 54, 274, 318, 436, 472) and specify flute, clarinet, two flutes, and flute or violin. These cues are usually of an extended nature and although they could be played on the piano were more effectively played on the specified instrument. Examples 14a and 14b, "Follow, follow thro' the sea" (1825, no. 274) by Vincente Martin y Soler, arranged by Henry R. Bishop, was published by Dubois \& Stodart in New York. It includes cues for horns and bugles placed on the staves for the right and left hands of the piano and several measures for clarinet (marked "Clar:" or "Clarinetto") on a third stave. Concert programs in England and America would often include songs or arias with instrumental obligato parts from well-known theatrical productions. For example, as part of a concert in Oxford on November 11, 1773, John and William Mahon performed the two clarinet parts to 
Arne's "Not unto us" from his oratorio Judith (written in 1761) with Miss Reynolds singing the vocal part. ${ }^{20}$

The printing of cues indicating instruments used in theatrical productions continued to appear in sheet music during the nineteenth century. Additional pieces with numerous cues indicating instruments were also transcribed for the piano, from the original band or orchestra versions, during the nineteenth century. These cues, however, were meant to be played on the piano. On the other hand, the use of more substantial parts for obligato instruments continued in sheet music throughout the nineteenth century. Songs and arias from operas or theatrical productions with short parts for instruments such as flute, violin, or clarinet were particularly popular and were performed regularly in these versions.

\section{Metronomic Indications}

Johann Nepomuk Maelzel (1772-1838) was a German inventor of automatic musical instruments and time-keeping devices. In about 1813 he invented a pendulumactivated timekeeper called a chronometer and in 1815 took out English, French, and Austrian patents on an improved device which he called a "metronome." The device was initially made in 1816 in London and Paris and consisted of a metal box measuring 31 centimeters in height. It was calibrated from 50 to 160 beats per minute and used a double-weighted pendulum. Maelzel promoted his metronome by shrewd advertising and sending samples to 200 composers all over Europe. Within a few years several composers indicated Maelzel Metronome (MM) numbers in their published works. During the $1820 \mathrm{~s}$ Maelzel improved his metronome by including a device to strike every two, three, four, or six beats; reducing the height to 20 centimeters made in a wood case; and, expanding the 
calibrations. The metronomes now included indications for 40 to 208 beats per minute and have remained unchanged to the present day. ${ }^{21}$

The earliest song in the Huntington's collection that includes a metronome indication is "Come rest in this bosom!" (no. 176) published New York by William Dubois in 1821. The indication is 88 beats per minute for one eighth note (printed MM $88=$ eighth note). Another song, "Oh, say not woman's love is bought" (no. 193) by John Whitaker was published in Philadelphia by George Willig in about 1822. Its metronomic indication is 50 beats per minute for one quarter note. There are probably earlier examples of metronomic indications on American sheet music, and this topic should be investigated. The use of these metronome markings could be used to recreate the tempos of these works for performance, even though the accuracy of metronomes of this period has been questioned.

\section{Conclusion}

This chapter briefly examined five topics relating to the publishing, engraving, lithography, and performance indications of American sheet music dating from 1793 to 1830. The writer endeavored to illustrate the diversity of methods of production and the changing nature of sheet music of this period. American publishers, engravers, and lithographers clearly imitated the earlier practices of their colleagues in England and elsewhere. In order to understand and appreciate sheet music from this period, however, it is important to identify which instruments were played, and how the performance might have been affected by indications in the music such as transposed versions of the melody, cues, additional parts, and metronomic indications. Pianos were very popular during this time but individuals also employed English guitars, recorders, flutes, clarinets, and flageolets for playing popular tunes. Finally, a survey of metronomic indications on sheet 
music in various collections could be taken to identify the publishers and composers who used metronomes in America and in Europe.

Notes

${ }^{1}$ For additional information regarding the layout and information found on title pages see Guide for Dating Early Published Music: A Manual of Bibliographical Practices, ed. D. W. Krummel (Hackensack, N. J.: Joseph Boonin, 1974), 88-94.

${ }^{2}$ The example numbers given here and througout the chapter refer to examples given in the text after the epilogue. The appendix numbers given here and throughout the chapter refer to the listing of specific songs given in the Appendix.

${ }^{3}$ Donald W. Krummel, "Graphic Analysis-Its Application to Early American Engraved Music," Music Library Association Notes, 16, no. 2 (March 1959): 217.

${ }^{4}$ Guide for Dating Early Published Music, 237.

${ }^{5}$ Among the many examples of title pages reproduced in modern sources several instructive examples are given by Donald W. Krummel in "Philadelphia Music Engraving and Publishing, 1800-1820: A Study in Bibliography and Cultural History" (Ph.D. diss., The University of Michigan, 1958), pls. 5-25; Krummel, "Graphic Analysis," pl. 2-7; and Guide for Dating Early Published Music, figs. 214-237.

${ }^{6}$ Richard J. Wolfe, Early American Music Engraving and Printing (Urbana: University of Illinois Press, 1980), 232

7Illustrated in Harry Dichter and Elliot Shapiro, Early American Sheet Music: Its Lure and Its Lore 1768-1889 (New York: R. R. Bowker Co., 1941), pl. 3.

${ }^{8}$ Wolfe, 234-35, 240, Table 8.

9Krummel, "Publishing and Printing of Music," The New Grove Dictionary of American Music (New York: Macmillan, 1986), III: 652. Lithographed music had been produced earlier in America by Henry Stone, an engraver in Washington, D.C. Stone lithographed the music of a song in 1823 entitled "The Generous Chief" in an unidentified collection of vocal and instrumental music. After about 1835 lithographic sheet music was not produced. See Wolfe, 230. Krummel dates Stone's use of lithography to around 1822 in "Publishing and Printing," III: 652.

${ }^{10}$ Illustrated as Fig. 1 in Nancy R. Davison, "The Grand Triumphal Quick-Step; or, Sheet Music Covers in America," in Prints in and of America to 1850, ed. John D. Morse 
(Winterthur Conference Report 1970; Charlottesville: The University Press of Virginia, 1970), 258-60.

"Virginia Larkin Redway, Music Directory of Early New York City (New York: New York Public Library, 1941), 35.

${ }^{12}$ Davison, 272.

${ }^{13}$ Wolfe, 230.

${ }^{14}$ Donald W. Krummel, English Music Printing 1553-1700 (London: The Bibliographical Society, 1975), 169. Transposition refers to raising or lowering the melody by changing the tonality of the song.

${ }^{15}$ See Edgar Hunt, The Recorder and Its Music (London: Eulenburg, 1976), 63.

${ }^{16}$ Engraved by George Bickham, Jr. (London: C. Corbett, [1740], 2 vols. Selections from this publication are found in The George Bickham Colouring Book (New York:

Performers' Editions, n.d.).

${ }^{17}$ See Robert Spencer and Ian Harwood, "English Guitar," The New Grove Dictionary of Musical Instruments (New York: Macmillan, 1984), 1: 706.

18Ibid.

${ }^{19}$ The capital letters indicate major keys; small letters indicate minor keys.

${ }^{20}$ See Pamela Weston, Clarinet Virtuosi of the Past (London: Robert Hale, 1971), 251.

${ }^{21}$ See David Fallows, "Metronome," The New Grove Dictionary of Musical Instruments, 2: 649-50; Rosamond E. M. Harding, The Metronome and It's [sic] Precursors (London, 1938; reprint ed., Henley-on-Thames: Gresham Books, 1983), 24. 


\section{EPILOGUE}

This study is concerned with three topics: American popular music, 1630 to 1830 ; the music trades, 1716 to 1830 ; and some aspects of the production of sheet music in the Huntington Library's collection, dating from 1793 to 1830 . The first chapter reviews the evidence concerning popular music in colonial America, the introduction of sheet music during the 1790 s, the various types of popular music, and the types of instruments specified in sheet music. My research discovered that there was a great interest in music in colonial Massachusetts during the seventeenth century and that musical instruments were brought to Massachusetts from England, purchased from England, and purchased from a few makers in New England. During the eighteenth century the earliest music teachers, music dealers, and public concerts were centered around Boston. Sheet music began to be produced in Philadelphia and New York in 1793, followed by Baltimore in 1794, and New York in 1798. This production was supported by the influx of musicians as well as the establishment of several theater groups in these locales. Most published songs were from comic operas or dramatic works, others were patriotic music and Scottish and Irish melodies. By the 1810s songs from Italian operas and "Englished" versions were produced, and during the 1820 s songs of the minstrel stage appeared. Most of the sheet music produced in America from 1793 to 1830 consisted of songs for voice with piano accompaniment, and piano solos. After 1800 , sheet music was produced as arrangements for piano four hands, solos for flute with piano accompaniment, and guitar solos.

Chapter two is a literature review of the subjects discussed in the thesis including valuable secondary sources. Two recent series have reprinted selected manuscript and sheet music composed during the late eighteenth and nineteenth centuries. Essential sources for the dating of sheet music are found in two detailed listings of sheet music 
dating from the eighteenth century through 1820. A directory of early American publishers is also a useful source. A general guide to dating early published music is helpful as well as a catalog of early American printed music in the Newberry Library. One study has appeared concerning early American music engraving and printing and there are a few specialized articles which are valuable. The largest number of sources are found concerning music printing, publishing, and musical instrument making in Boston and New York. These include studies by city and general listings of individuals who were active in these professions. Finally, a number of books and articles have been published concerning musical instruments and musical instrument makers which provide information about music publishers. Some studies are concerning only with American musical instruments, others with one specific instrument, and still others provide listings of instrument makers. There are areas where research remains to be accomplished. For instance, additional sheet music should be made available by reprinting since the vast majority of items may only be studied by reference to the original items. Updated editions are also needed for the listings of sheet music and the directory of early American publishers. Additional studies of music publishers and dealers need to be accomplished for cities where there was musical activity in the eighteenth century, such as Charleston and Baltimore. Finally, directories are needed for makers of percussion, mechanical, and automatic musical instruments.

Chapter three presents a history of the music trades from 1716 to 1830 . It reviews the evidence about music and instrument dealers active from 1716 to 1807 and investigates the activities of twelve music publishers who also sold their own instruments or instruments of American manufacture. Twenty-four music and instrument dealers who were active during the eighteenth and early nineteenth centuries are discussed The first of these began in Boston in 1716; others were established in Philadelphia and New York in 1759. The majority of music and instruments were imported from London although some 
items were made in colonial America. My research revealed that publishers in America during the late eighteenth and early nineteenth centuries were involved in a number of activities including selling or making instruments, engraving music, teaching, and performing. Of the twelve publishers investigated, four were notable for their large number of publications: Hewitt, Graupner, Blake, and Firth, Hall \& Pond. Four others contributed substantially to the manufacture of musical instruments: John Geib \& Sons, Riley, Firth, Hall \& Pond, and the Klemm Brothers.

The fourth chapter investigates certain aspects of sheet music in the collection of the Huntington Library. It discusses title pages, illustrations, optional melodic instruments, additional instruments, and metronomic indications. The changing nature of title pages during the late eighteenth and early nineteenth centuries, and their use in dating song sheets, are illustrated by examples from the Huntington's collection. Engravings as illustrations on title pages are discussed and several lithographs dating from 1826 and after are discussed and reproduced from the Huntington's collection. A few songs were published with a transposed arrangement of the melody written for flute, violin, guitar, clarinet, or flageolet. My research revealed that the earliest parts for flute may have been played on the recorder, and the earliest parts for the guitar were played on another instrument, the English guitar. In a few other song sheets, cues, or notes printed in smaller fonts, for additional or "obligato" instruments were printed. These parts are substantial enough to add to the musical texture but must still be considered optional since they could have been performed on the piano. Cues are also found in some examples for a variety of orchestral instruments because the song had originally been part of a theatrical production which included a small orchestra. These parts, however, were very likely played on the piano. Metronomic indications or numbers in sheet music were initially found in song sheets dating from 1821. Their appearance in sheet music has not been 
thoroughly traced and may be useful in recreating music of the period. The use of optional melodic instruments, additional instruments, and the indication of metronomic numbers in sheet music are three areas in which my research has provided some observations and conclusions.

The Appendix, a chronological listing of the cataloged and uncataloged sheet music in the Huntington Library, includes indexes of titles; composers and arrangers; publishers by city; and performance media. The bibliography is useful for the study of early American publishing and musical instrument making. These chapters broaden our understanding of the cultural history of America and indicate the importance of music in everyday life. They reveal the dominating influence of English musical practice in America and provide an overview of the beginnings of the music publishing and musical instrument industries in the country. This study, however, represents only a beginning of a systematic investigation into these topics. 
EXAMPLE 1

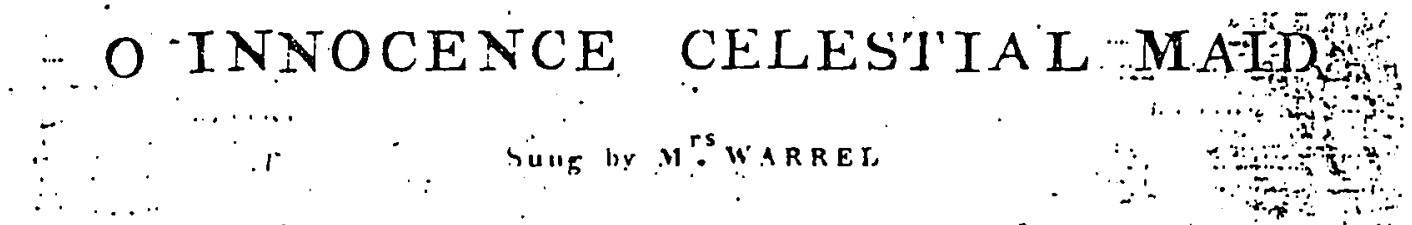

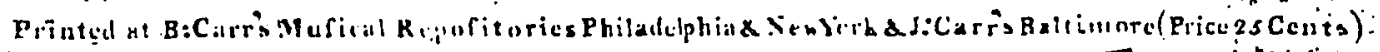

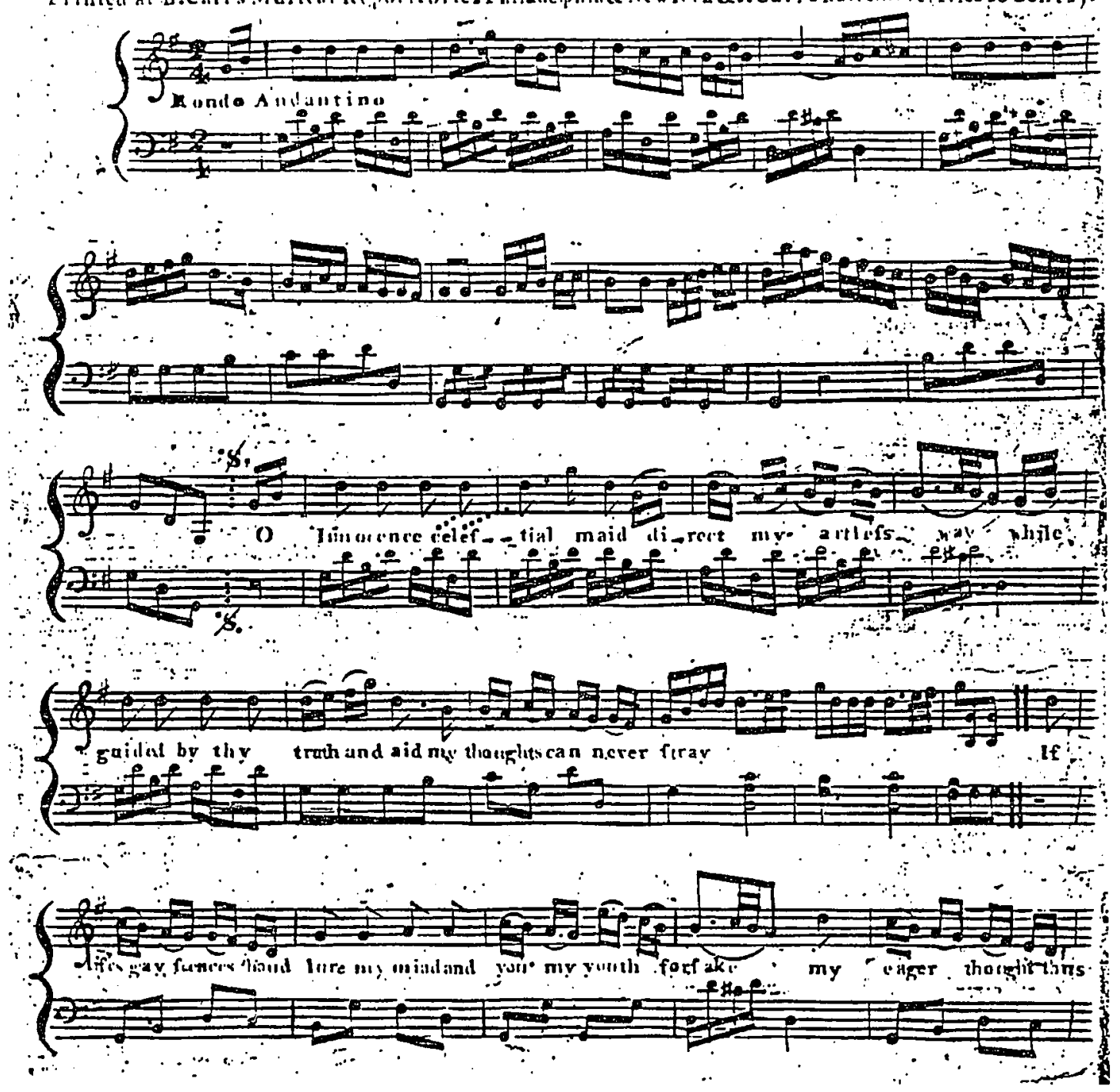

"O innocence celestial maid" (Philadelphia: B. Carr, 1797). 
EXAMPLE 2

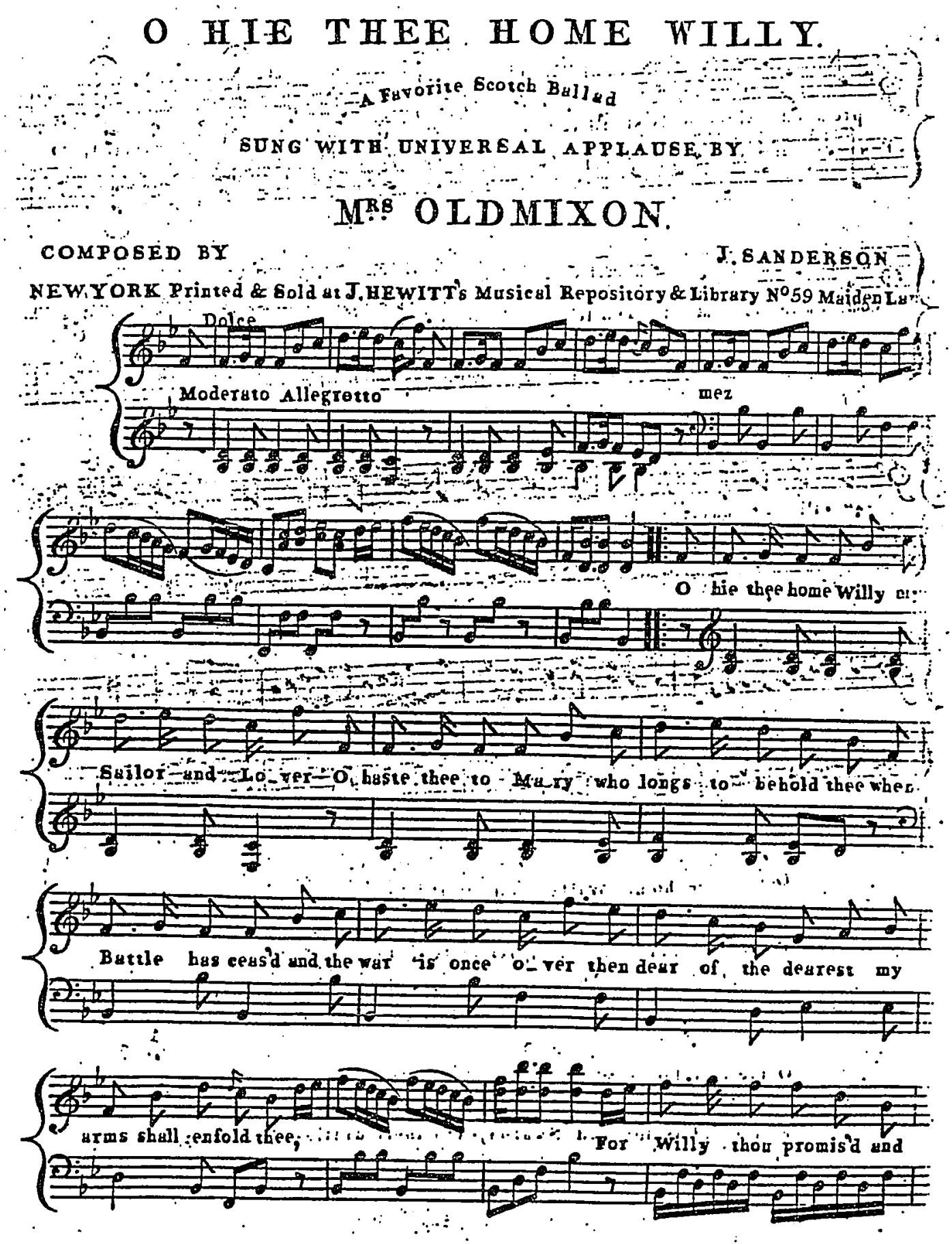

"O hie thee home Willy" by J. Sanderson (New York: J. Hewitt, 1809). 
EXAMPLE 3
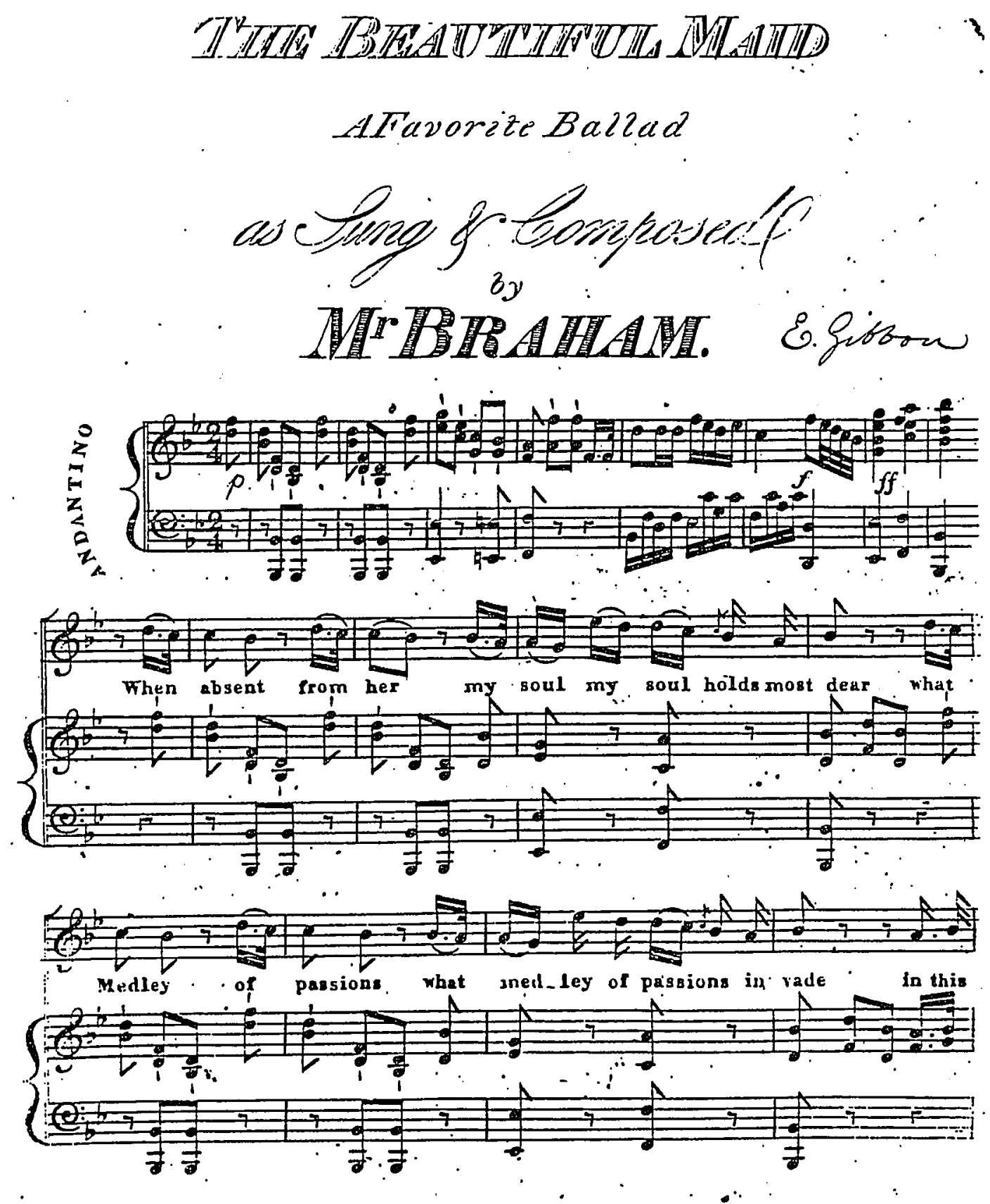

NEW YORK Published by Kin DUBOIs.

"The beautiful maid" by John Braham (New York: W. Dubois, 1817). 
EXAMPLE 4

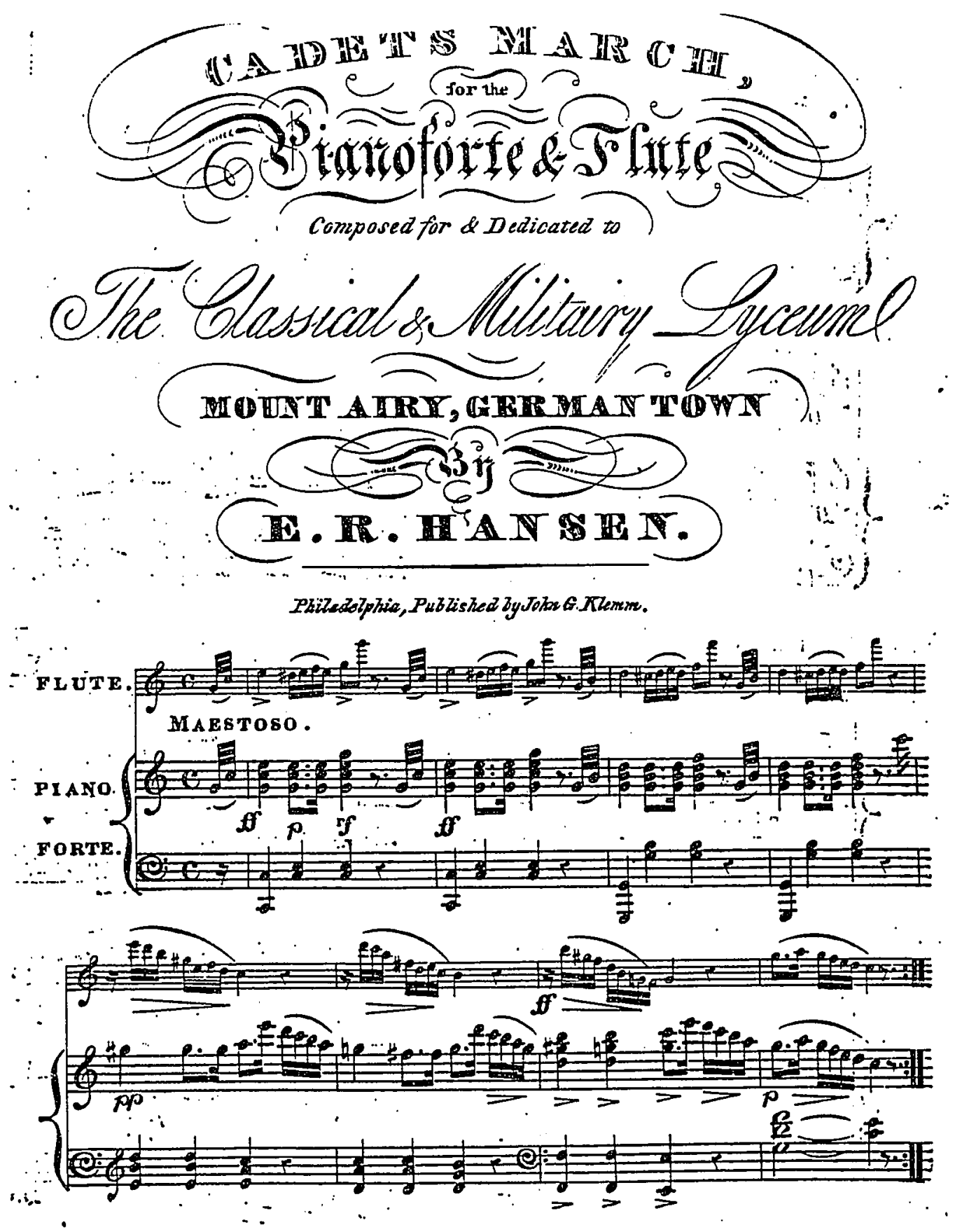

"Cadet's march for the pianoforte \& flute" by E. R. Hansen (Philadelphia: J. G. Klemm, ca. 1826). 
EXAMPLE 5

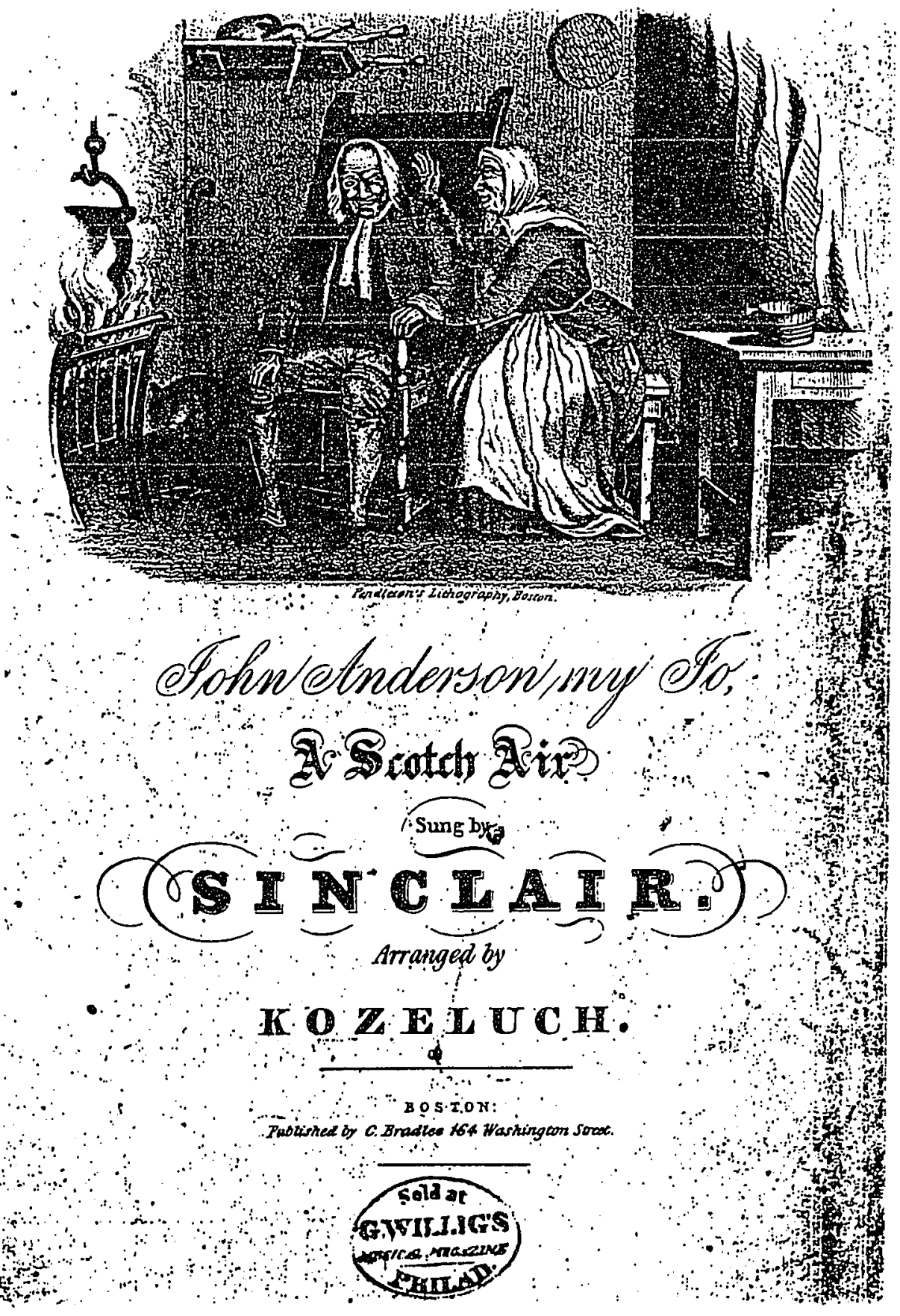

"John Anderson my Jo" arranged by Kozeluch (Boston: C. Bradlee, 1827-1835). 


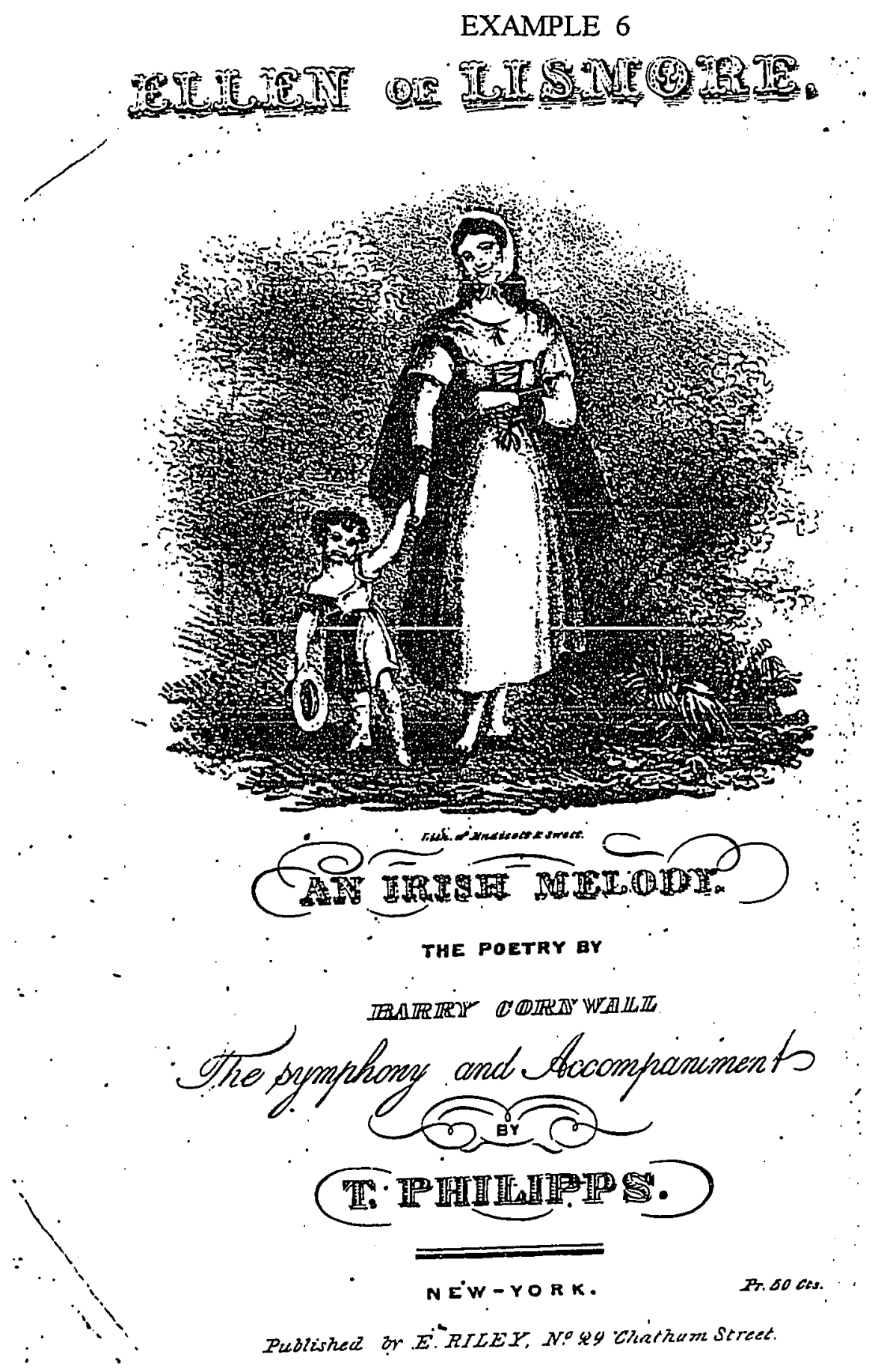

"Ellen of Lismore" by T. Philipps (New York: E. Riley, 1826-1831). 
EXAMPLE 7

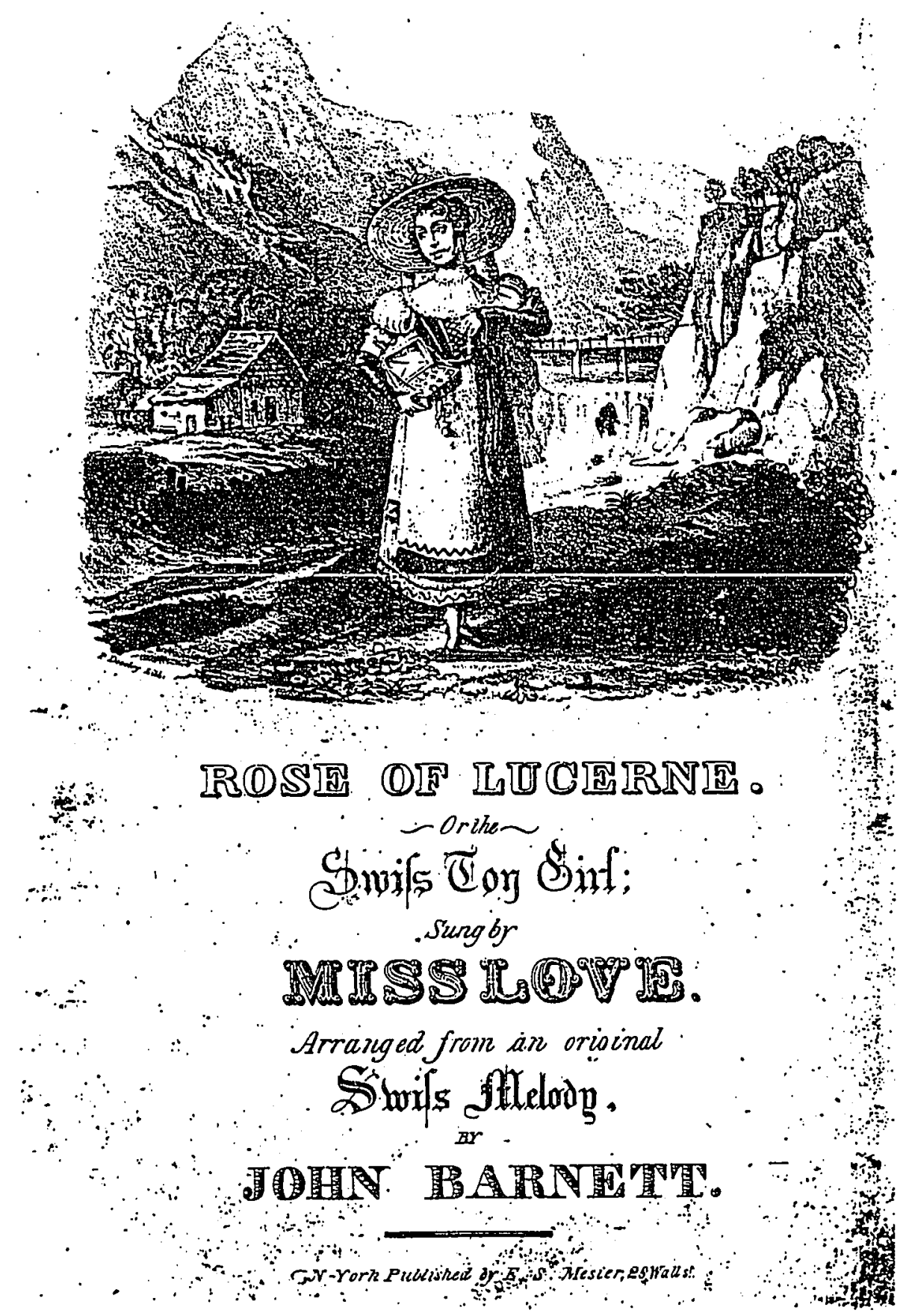

"Rose of Lucerne" by John Barnett (New York: E. Mesier, 1826-1832). 


\section{EXAMPLE 8}

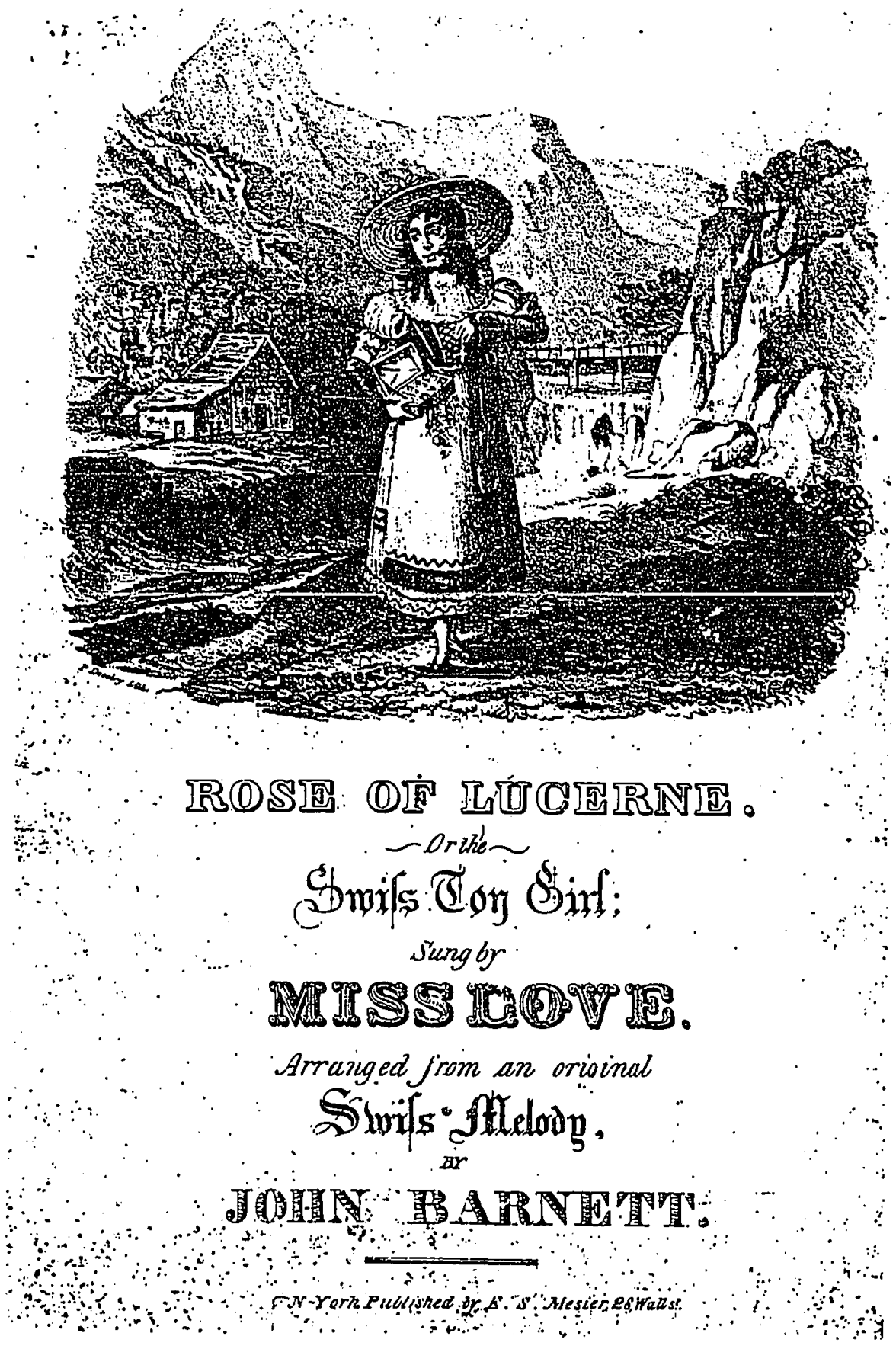

"Rose of Lucerne" by John Barnett (New York: E. Mesier, 1826-1832). 
EXAMPLE 9

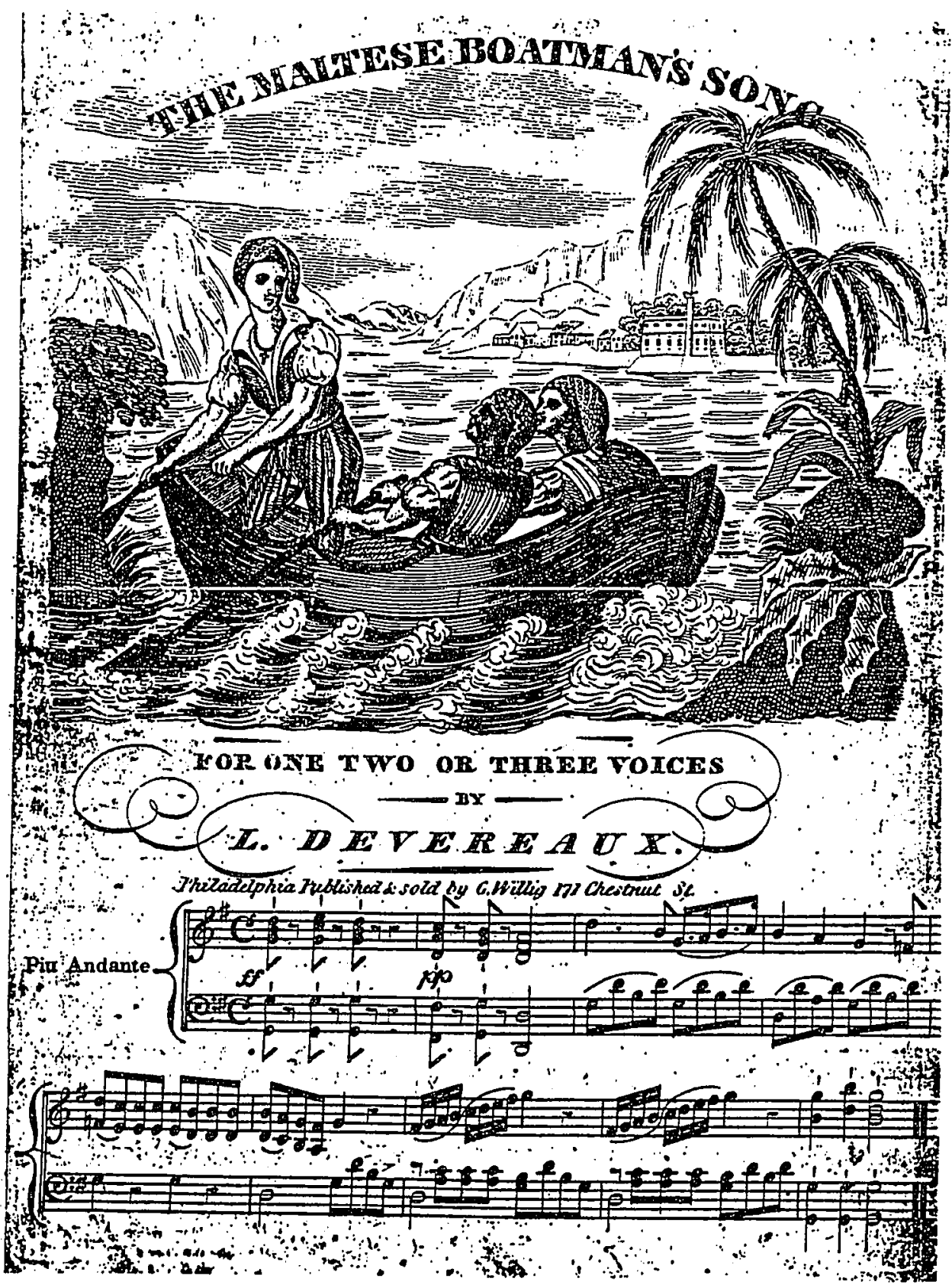

"The Maltese boatman's song" by L. Devereaux (Philadelphia: G. Willig, 1826-1851). 
EXAMPLE 10

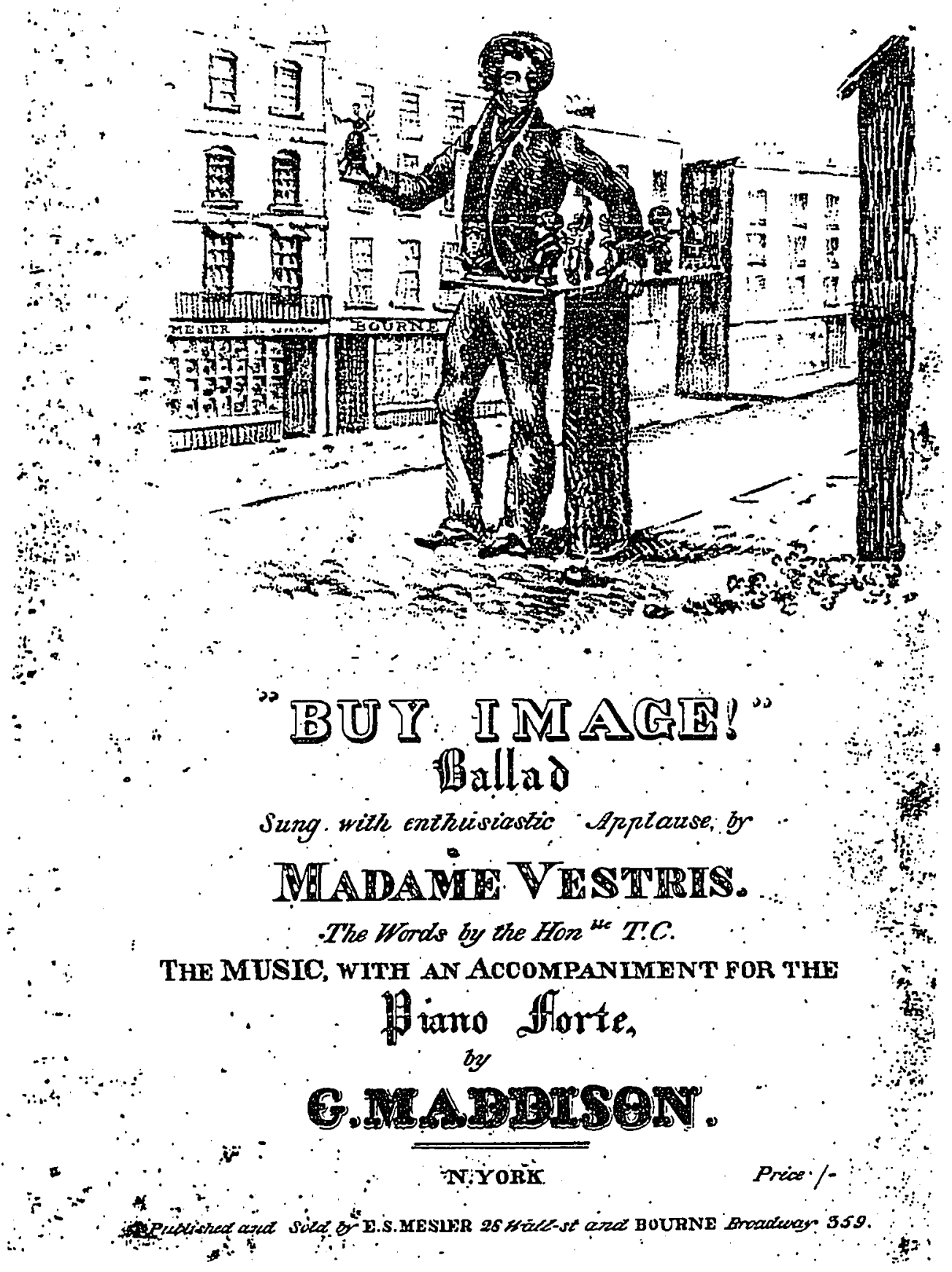

"Buy image!" by G. Maddison (New York: Mesier and Bourne, 1827-1832). 
EXAMPLE 11

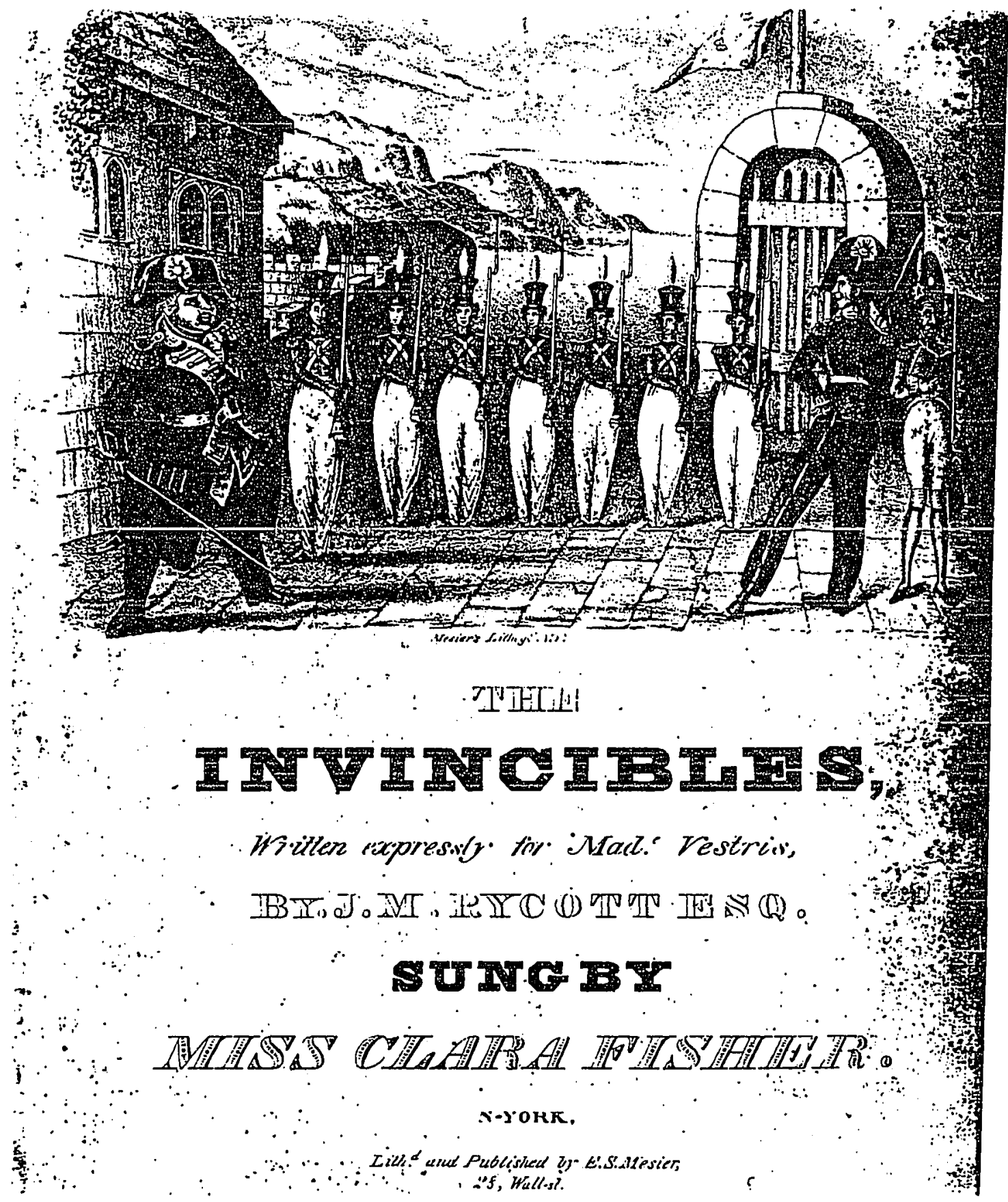

"The invincibles" by J. M. Rycott (New York: Mesier, 1826-1832). 


\section{EXAMPLE 12}

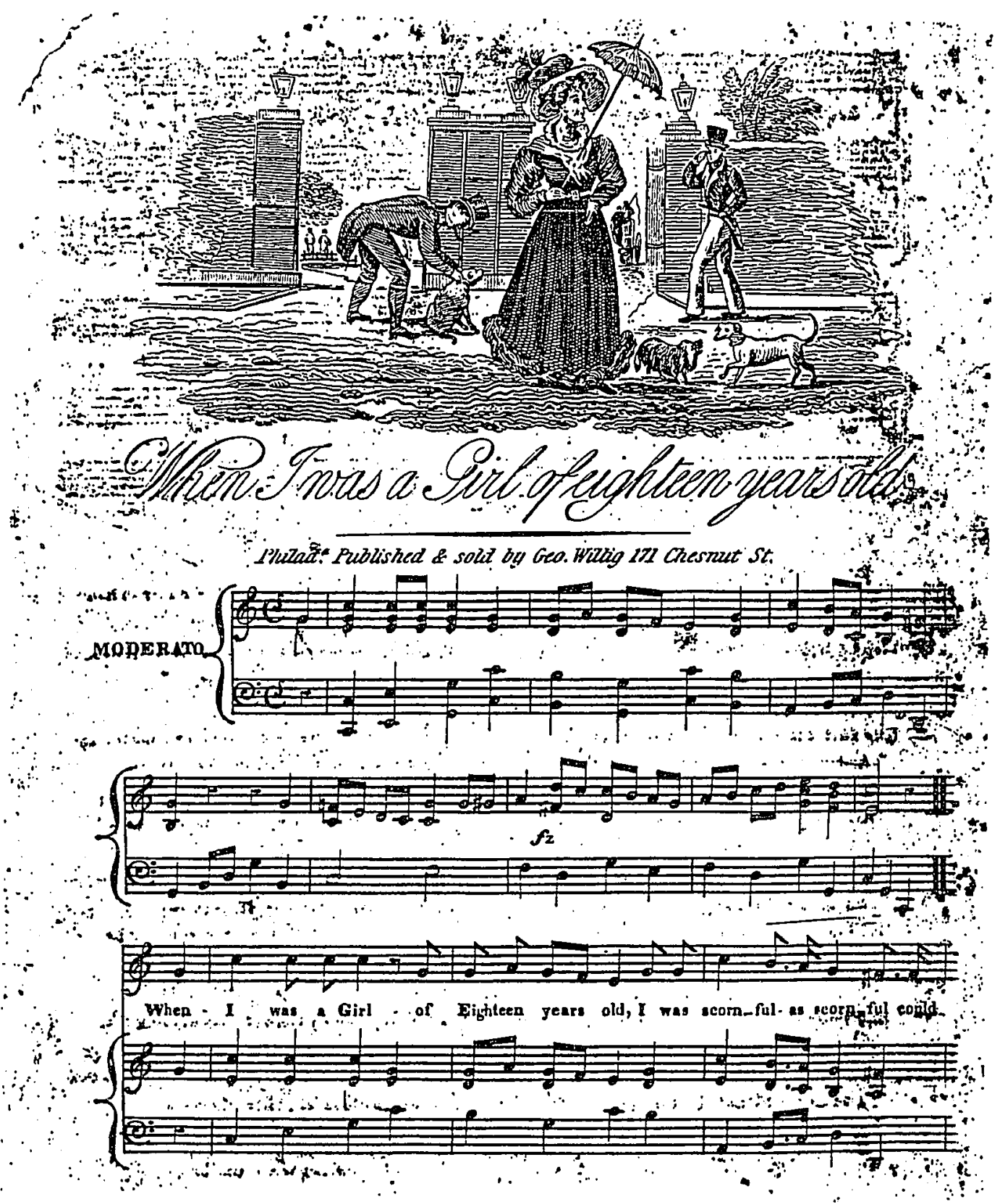

"When I was a girl of eighteen years old" (Philadelphia: G. Willig, 1826-1851). 
EXAMPLE 13

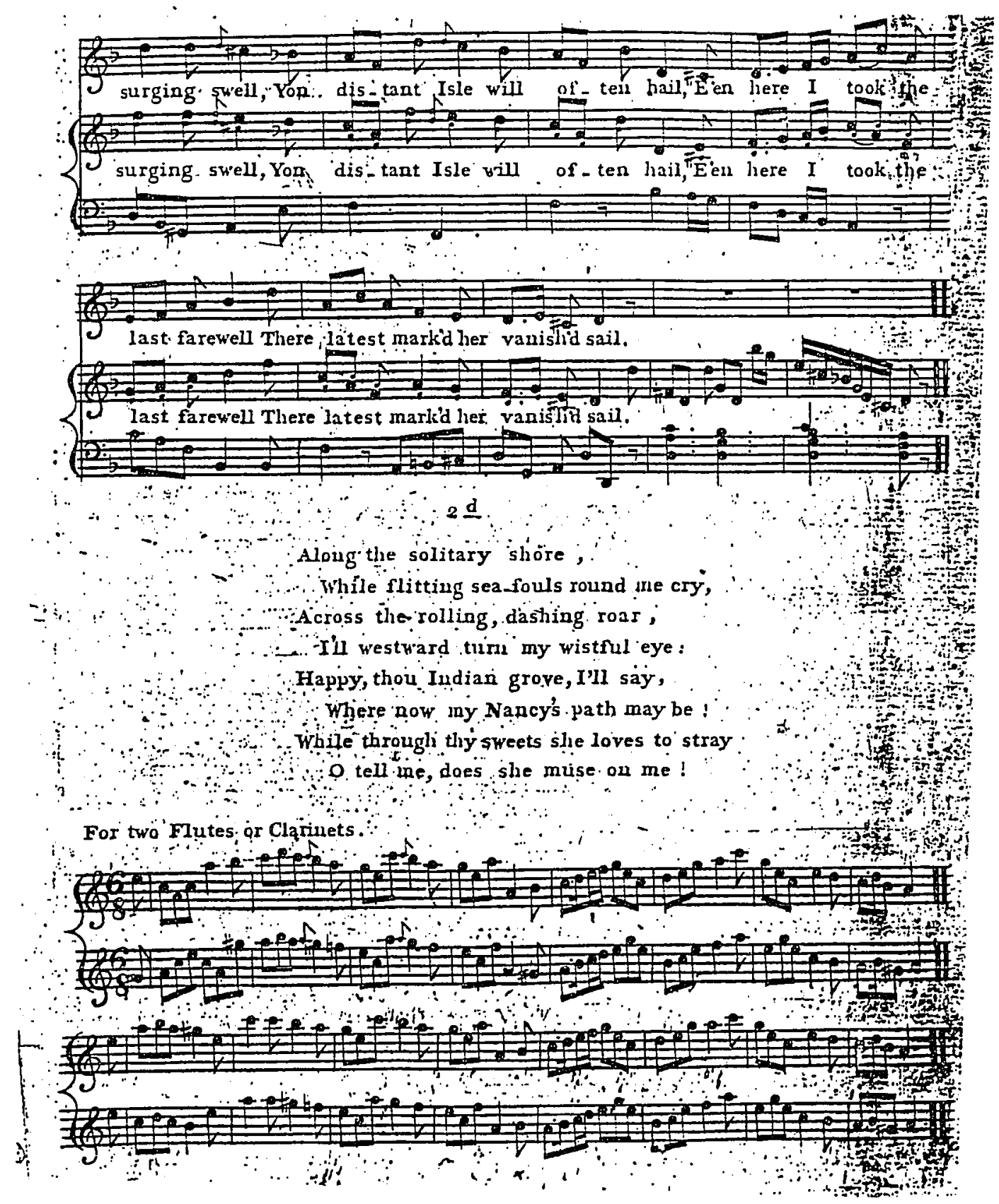

"The farewell" (Philadelphia: G. Blake, 1807-1808). 
EXAMPLE $14 a$

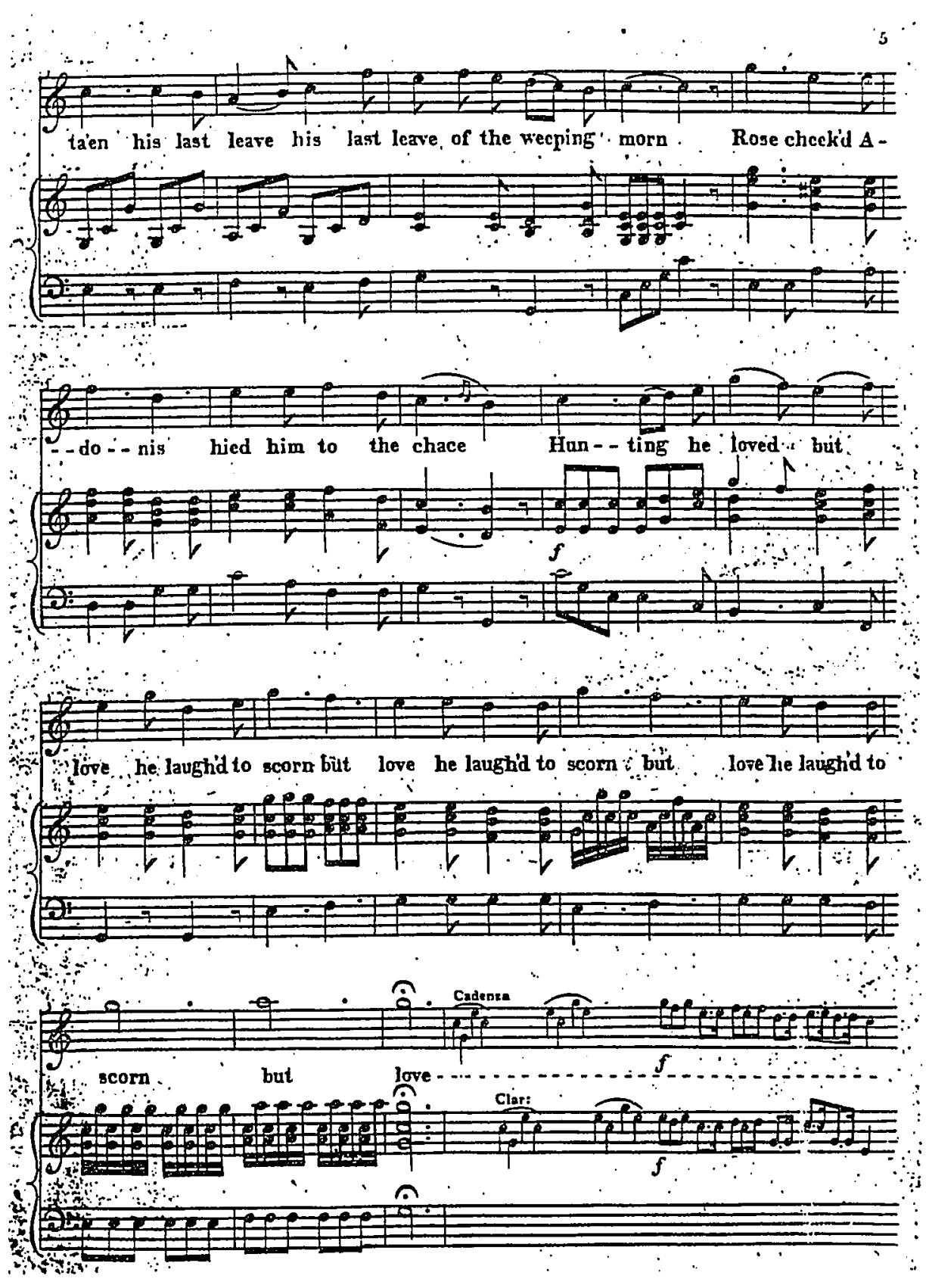

"Follow, follow thro' the sea" by Vincente Martin y Soler, arranged by Henry Bishop

(New York: Dubois \& Stodart, 1825). 


\section{EXAMPLE $14 b$}

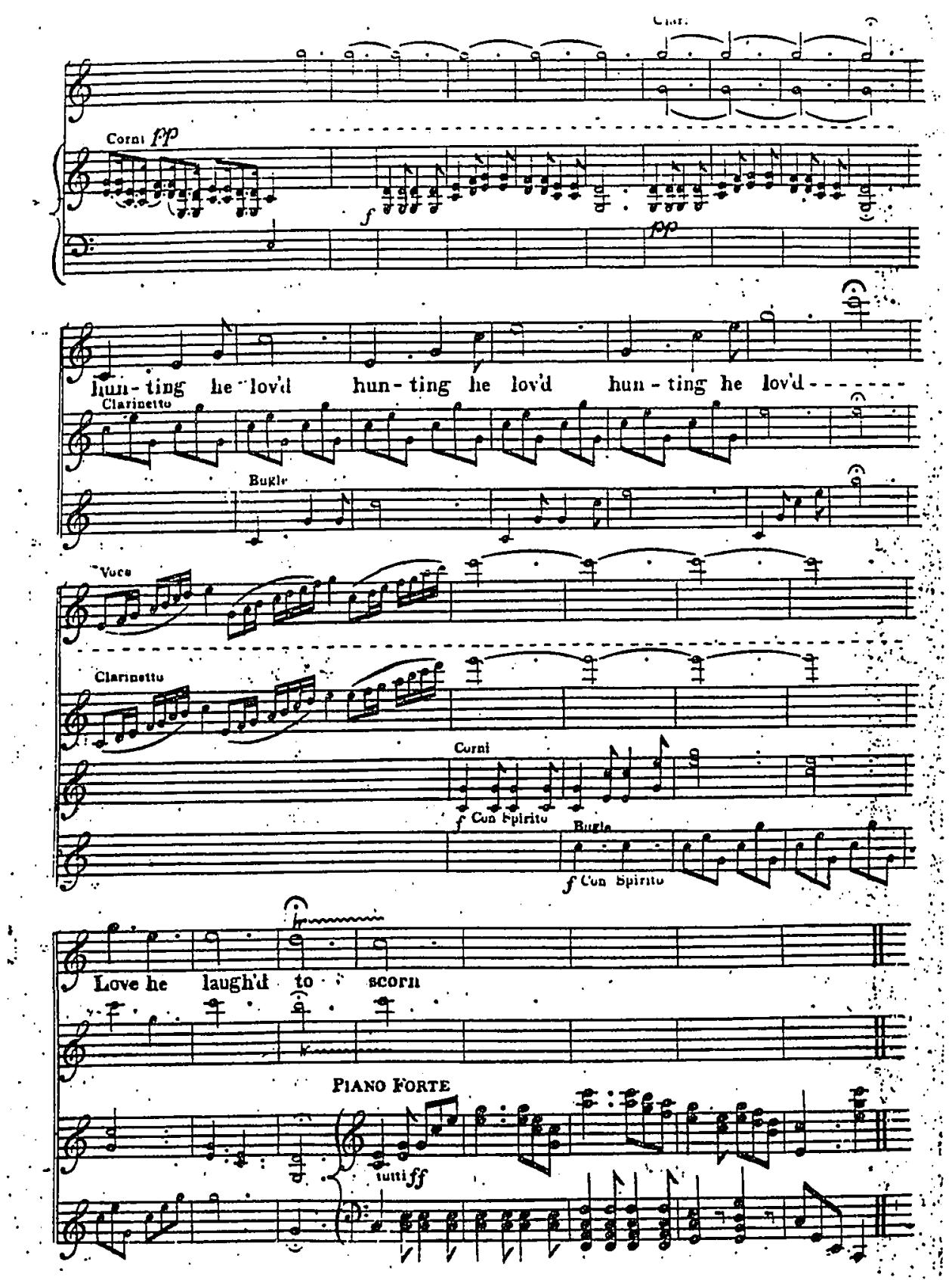

"Follow, follow thro' the sea" by Vincente Martin y Soler, arranged by Henry Bishop

(New York: Dubois \& Stodart, 1825). 


\begin{abstract}
APPENDIX
This appendix is a list of the Huntington Library's American sheet music holdings dating from 1793 to 1830 . These holdings include 551 items of published and manuscript music representing most of the important publishers of the period. Items are arranged chronologically by publication date.

The definition of sheet music for this listing includes songs with piano, harp or guitar accompaniment; piano solos; two-, three- and four-part choruses with and without accompaniment; guitar solos; a piano instruction book containing several solos; and pieces for various instruments with piano accompaniment. Most of these items are on folio sheets, folded in half to form two pages; also included, however, are single sheets or broadsides; songs of three pages or more; collections of vocal and piano music; items written for combinations of voice and/or instruments; "sacred" music with piano accompaniment (such as funeral dirges); and music printed in four songsters or collections of poems and song lyrics (nos. 9, 37, 72, and 94). There are several bound volumes of individual music sheets which are identified by the embossed name of the owner appearing on the cover, such as, "Harriet A. Stanton."

Secular music in the Huntington Library's collection which is not included are a few pieces in three collections of sacred tunes by William Billings (1778), Samuel Holyoke (1791), and Oliver Holden (1792); and the secular tunes included in the Massachusetts Magazine (1789-92).

The reader may wish to consult three important reference sources for additional information concerning dating, the publishing history of particular works, and publishers. These are: A Bibliography of Early Secular American Music [18th century] by Oscar George Theodore Sonneck, revised and enlarged by William Treat Upton (Washington, DC.: The Library of Congress, 1945); Secular Music in America, 1801-1825; a
\end{abstract}


Bibliography by Richard J. Wolfe (New York: The New York Public Library, 1964), 3 volumes; and Early American Sheet Music: Its Lure and Its Lore 1768-1889 by Harry Dichter and Elliott Shapiro (New York: R. R. Bowker Co., 1941).

Since the vast majority of sheet music is not dated, dates have been supplied by research in the sources noted above. These sources are referred to in abbreviated form as: Sonneck-Upton, Wolfe, and Dichter \& Shapiro. Using these books, many items were dated to a specific year or a range of years based on the address of the publisher or advertisements of newly published music. The following additional sources were consulted and proved helpful in dating and providing additional information concerning publishers: Guide for Dating Early Published Music: A Manual of Bibliographical Practices, ed. D. W. Krummel (Hackensack, NJ: J. Boonin, 1974) (noted as Krummel), and D. W. Krummel, "Supplement to the Guide for Dating Early Published Music," Fontes Artis Musicae 24 (1977): 175-84 (noted as Krummel, Supplement, for dating by reference to publisher's or plate numbers); Music Printing and Publishing, eds. D. W. Krummel and Stanley Sadie (New York: W. W. Norton, 1990) (noted as Krummel \& Sadie, for publisher's activities); Annals of the New York Stage by George Odell (New York: Columbia University Press, 1927-49), 15 volumes (noted as Odell, for dating performances of stage works in New York); and Early American Music Printing and Engraving by Richard Wolfe (Urbana: University of Illinois Press, 1980) (noted as Wolfe, 1980 , for information concerning watermarks found on music sheets). Another source useful in locating songsters at the Huntington was Irving Lowens's A Bibliography of Songsters Printed in America Before 1821 (Worcester: American Antiquarian Society, 1976).

This list represents only a portion of the sheet music collection in the Huntington Library. Several of the earliest imprints were cataloged but the majority of the music in 
the list remains uncataloged. The method of listing sheet music is the same as used by Sonneck-Upton and Wolfe in their bibliographical listings. The main entry consists of the title of the work, with a composer given if known or identified. To facilitate locating works, following the main chronological listing are indexes of titles, composers or arrangers, publishers by city, and performance media. An analysis of these indexes indicates that the cities most active in publishing during this period were Philadelphia, New York, Baltimore, and Boston. The most prominent publishers were Willig, Riley, Dubois, Dubois \& Stodart, Klemm, Blake, and Willig, Jr.

The Huntington Library's collection includes a few rare items not located by Wolfe in his three-volume bibliography and one very rare item not located in Sonneck-Upton or Wolfe: "Emblems of mem'ry are these tears" (Philadelphia: G. Willig, 1798-1804, no. 15); "Twelve little ballads and a favorite lesson" (Philadelphia: G. Blake, 1810-1814, no. 58); and "The musical magazine" (Boston: G. Graupner, 1802-1803, 3 vols., no. 31), one of the only complete sets known of this item. Fourteen songs (nos. 1, 4, 10, 11, 17, 18, 21, $28,31,46,81,86,103,133)$ include a transposed melody line printed as a separate section at the end of the music sheet and labeled for flute, violin, clarinet, guitar, and flageolet. The amateur performer of these songs played the melody on an instrument alone. The tonality of these arrangements differs from that of vocal and keyboard song and is noted as such. These arrangements were written for amateur performers in tonalities which were easier to play than the original tonality of the song. Additionally, there are thirteen works with lithographs which are described (nos. 337, 371, 380, 381, $404,423,444,449,452,507,538,548,550)$ and, if known, the lithographer is identified. All of these items were published after 1826, and the lithographs on the title pages are from one-third to a full page in length. These include two copies of Ellen of Lismore 
(New York: E. Riley, 1826-32, nos. 380 and 381) which illustrate a young woman in an outdoor scene, but the hair color and length of hair of the woman differ in each copy.

Cues or notes printed in a smaller font are noted in ten songs (nos. 17, 88, 129, $230,241,274,318,338,477,549)$ and identified with various instruments, such as oboe, corni (horns), drums, trumpets, flutes, violin, bugle, clarinet, and cello. This music was arranged for voice and piano from popular stage music which included a small orchestra. In five items (nos. $52,274,318,436,472$ ) instrumental parts are provided in cues to be played along with the voice part during the song or in cadenzas. These instruments include flute, clarinet, two flutes, and flute or violin. The designation "flute" in late eighteenth century America could have referred to a recorder as the name "German flute" (for transverse flute) is also specified by publishers such as Graupner. The name "guitar" referred to the "English guitar," a type of cittern with six courses of ten strings tuned to ce-g-c'-e'-g'. By the 1820s sheet music specified the "Spanish guitar," the familiar six-string instrument. The perferred accompaning instrument for songs during the late eighteenth and early nineteenth centuries was the popular square piano. However, the harpsichord had not completely vanished from American households as the collection entitled "A selection of the most admired ballads" (no. 26) published in Philadelphia by John Morgan in 1801, was "set to the harpsichord \& piano forte." Clearly, here is an example of the optional use of harpsichord or piano. Other examples of keyboard accompaniment in which the player appears to have been given an option to play on the harpsichord or piano are: "The American Musical Miscellany" (1798, no. 9) which includes 111 songs, some with a simple bass line; "Emblems of mem'ry are these tears" (1798-1804, no. 15) which has several indications of the printed numeral " 8 " (indicating an octave doubling) below the right-hand part; and "Sacred dirges, hymns, and anthems" (1800, no. 22) which includes an instrumental bass part with solo voice. 
Watermarks to 1803 were identified visually (additional marks may be found with the use of beta-radiographs.) Also noted are copyright deposit statements and stamps of dealers and publishers (other than the original publisher) who sold the music. In a few cases a dealer's name and location were printed on the music. The items in this list are recorded with the original spelling and punctuation, although a few obvious misspellings are noted with an explanation mark in brackets. Manuscript songs are included when they could be identified with published works. 


\section{AMERICAN SHEET MUSIC AT THE HUNTINGTON LIBRARY,}

1793 TO 1830

1) Sweet lillies of the valley. Sung with great applause at Vauxhall Gardens. Composed by Mr. Hook. Philadelphia: Carr \& Co. [1793]. Catalog \#449632.

2 pp. Voice w/piano acc. Following on p. 2 is a version of the melody (in C major) arr. for guitar. The work is written in A major. Composed by James Hook.

Watermark: SC with a six-pointed star, possibly Simon Class, Lower Merion,

Montgomery County, Pennsylvania (Wolfe, 1980, 285, no. 41).

Dating: Sonneck-Upton, 415-16.

2) The President's march. Aranged [!] for two performers on one piano forte by R. Taylor. Philadelphia: Wm. Priest. [ca. 1795]. Catalog \#182221.

2 pp. Piano four hands. Composed by Raynor Taylor.

Watermark: J KOOL (Jan Kool) in between pp. 1 and 2, not traced by Wolfe (1980).

Dating: Sonneck-Upton, 342.

3) The new presidents march [Philadelphia]: B. Carr [1796]. Catalog \#182310.

1 p. Piano solo

With Washington's march.

There is also a second photostat copy with the same catalog number.

Watermark not present.

Dating: Sonneck-Upton, 452.

4) Lucy or Selim's complaint. A favorite song. Composed by Mr. Hook. Philadelphia: B. Carr [ca.1796]. Catalog \#150315.

2 pp. (paginated 88-89). Voice w/piano acc.

Melody part arr. for flute (G maj.), and guitar ( $\mathrm{C}$ maj.). Composed by James Hook.

The work is written in $\mathrm{F}$ major.

Watermark not present.

Dating: Sonneck-Upton, 242.

5) Par sa legéreté. [Philadelphia: Filippo Trisobio, 1796-98]. Catalog \#150389.

1 p. Voice w/piano acc.

Watermark: Dirk Blauw \& Co., similar to Wolfe (1980), no. 2 without the crest, not identified by Wolfe.

Dating: Sonneck-Upton, 325.

6) The battle of Trenton. A sonata for the piano-forte. Dedicated to General Washington. New York: James Hewitt [1797]. Catalog 131135.

14 pp. Piano solo. Composed by James Hewitt.

Bound in Washington Irving, Life of George Washington (New York, 1857), vol. 2, part

3 , between pp. 488-89.

Watermark not present.

Dating: Sonneck-Upton, 39.

7) O innocence celestial maid. Sung by Mrs. Warrel. Philadelphia and New York: B. Carr and Baltimore: J. Carr. [1797]. 
$2 \mathrm{pp}$. Voice w/piano acc.

Watermark not present.

Dating: Sonneck-Upton, 305.

8) Nobody. Composed by R. Taylor. Philadelphia: B. Carr [1797-99]. Catalog \#150322.

2 pp. Voice w/piano acc. Composed by Raynor Taylor.

Watermark not present.

Dating: Sonneck-Upton, 300.

9) The American Musical Miscellany. A collection of the newest and most appoved [!] songs, set to music. Northampton, Massachusetts: Andrew Wright, 1798. Catalog \#243443.

$300 \mathrm{pp}$. One hundred and eleven songs, numbered I-CXI. The music is printed from movable type. The majority of the pieces show words and tune only, but several are set for two, three, and four voices. The arrangement generally is such as to allow an accompaniment on the piano in unison with the voice or voices. In the two-part songs the right hand plays the tune and the left a simple unfigured bass. In some instances short preludes or postludes are found.

Watermark not present.

A list of song titles is given in Sonneck-Upton, 17-20.

Dating: Sonneck-Upton, 16-20.

10) The favorite new federal song. Adapted to the Presidents march. Sung by Mr. Fox. Written by J. Hopkinson Esqr. [Philadelphia: B. Carr, 1798]. Catalog \#182222. $2 \mathrm{pp}$. Voice w/piano acc. Melody for flute or violin (in D major, the piano part and melody written in $\mathbf{C}$ major).

At the head of the music: "For the Voice, Piano Forte, Guittar and Clarinett."

Watermark: Dirk Blauw \& Co., Wolfe (1980), no. 40, not indicated by Wolfe.

Dating: Sonneck-Upton, 173.

11) New Yankee Doodle. Sung with great applause at the Theatre by Mr. Hodgkinson. New York: J. Hewitt [1798]. Catalog \#182311.

2 pp. Voice w/piano acc. Melody arr. for flute, p. 2 (in D major, the work is written in C major). Composed by John Hodgkinson.

Within the title is an oval portrait marked "G. Washington."

Watermark not present although Wolfe $(1980,273)$ reported William Elcar's mark.

Dating: Sonneck-Upton, 480 and Dichter \& Shapiro, 204.

12) Adams and liberty. New York: C. Gilfert [1798-1801]. Catalog \#131135.

2 pp. Voice w/piano acc.

In the title is an engraved circular portrait of Adams.

Bound in Washington Irving, Life of Washington (New York, 1857), vol. 1, part 3, between pp. 426 and 427.

Watermark not present (however, both sheets are glued to the leaves of the book)

Dating: Sonneck-Upton, 4.

13) Blossom loveliest flower. A new song composed by Schulz. Philadelphia: G. Willig [1798-1804]. Catalog \#150319.

1 p. Voice w/piano ca.

Watermark not present. 


\section{Dating: Sonneck-Upton, 44.}

14) Crazy Emma. The words by a lady of Queen Ann's county. Music by J. B. Gauline. Philadelphia: G. Willig [1798-1804]. Catalog \#150299.

Watermark not present, although Wolfe $(1980,282)$ found a mark by J. Kool, no. 37. 2 pp. Voice w/piano acc.

Dating: Sonneck-Upton, 93.

15) Emblems of mem'ry are these tears. Sung by Mrs. Warrel at the New Theatre. In commemoration of the first anniversary of General Washington's birth-day after his decease 22d Feby 1800. Philadelphia: G. Willig no. 185 Market St. [1798-1804]. Catalog \#150298.

$2 \mathrm{pp}$. Voice w/keyboard acc.

Watermark not present.

The keyboard part includes several indications for octaves using the numeral" 8."

Rare item; not recorded in Sonneck-Upton or Wolfe.

16) 'Twas in the sultry noon-tide hour. A favorite song. Philadelphia: G. Willig [17981804]. Catalog \#150323.

2 pp. Voice w/piano acc.

Watermark not present.

Dating: Sonneck-Upton, 213.

17) The wounded hussar. Composed by Mr. Hewitt. Philadelphia: G. Willig [1798-1804]. Catalog \#150313.

2 pp. Voice w/piano acc. in F major. With an arrangement for "Flute or Quitar" in G major.

Cues written for oboe and corni, p. 1.

Watermark not present, although Wolfe $(1980,279)$ found a mark by MA, no. 27.

Dating: Sonneck-Upton, 478.

18) Dead march \& monody. Performed in the Lutheran Church, Philadelphia on Thursday, the 26th December 1799 being part of the music selected for funeral honours to our late illustrious cheif [!] General George Washington. Composed for the occasion and respectfully dedicated to the Senate of the United States by their obet. humble servt. B. Carr. Baltimore: J. Carr [1799-1800]. Catalog \#182313.

2 pp. Piano solo, Voice w/piano acc., two voices in E-flat major. Composed by Benjamin Carr.

Includes: Dead March; Monody, Sung by Miss Broadhurst; Dead march adapted for two flutes, violins, clarinetts or guittars; Monody adapted for two voices, flutes, violins, clarinetts or guittars in $\mathrm{G}$ major.

Watermark not present.

Dating: Sonneck-Upton, 100-101.

19) Funeral dirge on the death of General Washington. As sung at the Stone Chapel. The music composed by P.A. von Hagen, organist of said church. Boston: P.A. von Hagen [1800]. Catalog \#182312.

1 p. 2 voices $w /$ piano acc.

Watermark not present.

Dating: Sonneck-Upton, 152. 
20) A funeral elegy on the death of General George Washington. Adapted to the $22 \mathrm{~d}$ of February. By Abraham Wood. Boston: Thomas \& Andrews, Jan. 1800. Catalog \#51991 8 pp. Four-part chorus.

Watermark not present.

Dating: Sonneck-Upton, 152.

21) Let Washington be our boast. Sung with great applause at The Theatre at the conclusion of the Ode to the memory of Gen'I G. Washington. The words written \& music selected by Mr. Hodgkinson. New York: J. Hewitt [1800]. Catalog \#150314. $2 \mathrm{pp}$. Voice w/piano acc. in D major. Melody arr. for guitar ( $\mathrm{C}$ major). Composed by John
Hodgkinson.

The work is written in $\mathrm{D}$ major.

Watermark not present.

Dating: Sonneck-Upton, 227.

22) Hark from the tombs, \&c. and Beneath the honors, \&c. Adapted from Dr. Watts and set to music by Samuel Holyoke, A.M. Performed at Newburyport, 2d, January, 1800. The day on which the citizens unitedly expressed their unbounded veneration for the memory of our beloved Washington. Exeter: H. Ranlet [1800]. Catalog \#75170.

12 pp. (missing p. 1). Three- or four-part chorus w/parts which have a keyboard acc. in "Beneath the honors."

Watermark not present.

Dating: Sonneck-Upton, 178.

23) Sacred dirges, hymns, and anthems. Commenorative [!] of the death of General George Washington, the guardian of this country and the friend of man. An original composition by a citizen of Massachusetts. Boston: I. Thomas and E.T. Andrews [1800].
Catalog \#81784.

24 pp. Three-part chorus; voice w/instrumental bass.

Contents: pp. 5-11, A funeral anthem; 12-13, Columbia's guardian sleeps in dust; 14-15, Mount Vernon; 15-17, A dirge; 18-19, A hymn; 20-21 Anniversary dirge by Rev. T.M.

Harris; 22-23 Masonic dirge by Rev. T.M. Harris; 23, A funeral hymn; 24, An ode for the $22 \mathrm{~d}$ of February.

Watermark not present.

Dating: Sonneck-Upton, 366.

24) The musical journal for the piano forte. In two sections, one of vocal and one of instrumental music. Selected and arranged by Benjamin Carr. Baltimore: J. Carr; New York: J. Hewitt; Philadelphia: J. Chalk, vol. 2 [1800-1801]. Catalog \#151496.

$22 \mathrm{pp}$. (incomplete). Voice w/piano acc., violin or flute w/piano acc., and piano solo. Contents: Vocal section, No. 33, pp. 19-20: Heigh ho no ni no by Michael Kelly. No. 35, pp. 21-22: The sailor an elegy by Filippo Trajetta. No. 39, pp. 29-31: Zephyrs of the vernal morn [for two voices] by Benjamin Carr; pp. 32-4: Why huntress why by Benjamin Carr. Instrumental section, No. 36, pp. 21-4: Sonata by Pleyel for violin or flute w/piano acc. No. 46, pp. 41-44: Roxalana by Haydn adapted by James Hewitt. No. 48, pp. 45-7: A miscellaneous sonata in which is introduced the air of lullaby and the musical bells composed by Sigr. Zampieri.

Watermark not present.

Dating: Wolfe, II, 622, \#6377. 
25) Let truth and spotless faith be thine. A new song composed by Mozart. Philadelphia: G. Willig [1801]. Catalog \#150316.

$1 \mathrm{p}$. Voice $\mathrm{w} / \mathrm{piano}$ acc.

Watermark not present.

Dating: Wolfe II, 609, \#6254.

26) A selection of the most admired ballads, taken from the newest comic operas and Vauxhall entertainments. Composed by the ablest masters and set to the harpsichord \& piano forte. Philadelphia: John Morgan, 1801. Catalog \#328140.

$25 \mathrm{pp}$. Voice w/harpsichord or piano acc.

Contents: pp. 1-3 Claudine by Reinagle; 4-5 Tho fortune shuns my lowly cot by Hook; 6-7

Flatt'ring lovers often swear; 8-10 The dear little girl of his heart by Sanderson; 11-13 The complaint by Nicks; 14-15 When the evening closes in; 16-17 Anna of the Tyne by Hook; $18-20$ Each coming day by Atwood; $21-23$ The river queen by Bland; 24-25 'Twas in the
solemn midnight hour by Bland.

Watermark not present.

Dating: Wolfe II, 785, \#7885.

27) The blue bell of Scotland with variations composed by Adam Geib. And most Respectfully Dedicated by Permission to Madam Desobry. New York: J. Hewitt [1801?]. 6 pp. Piano solo. Music attributed to Dorothea Bland Jordan (Wolfe, II, 456, \#4672).

Dating, Wolfe, II, 456, \#4672.

28) The vail, or Stranger think me not too bold. An admired song in the favorite new musical drama of II bondocani. Composed by I. Moorehead. Philadelphia: R. Shaw, Baltimore: J. Carr, New York: J. Hewitt [1801?]. Catalog \#151490.

2 pp. Voice with piano acc. in $\mathrm{G}$ major. Arrangement for guitar $\mathrm{C}$ major.

Dating: Wolfe II, \#6081.

29) Sweetly in life's jocund morning. A favorite song in the new comedy of life. Words by Reynolds. Music by Mazzinghi. n.p. (in the Musical Journal for the Piano Forte, Philadelphia: B. Carr) [1801-02]. Catalog \#151494.

2 pp. Voice w/piano acc.

Watermark not present.

Dating: Wolfe II, 556, \#5725A; II, 623, \#6377.

30) The beggar girl. A favorite song or duett by H. Piercy. n.p. ([in the Musical Journal for the Piano Forte] Philadelphia: B. Carr) [1802-03]. Catalog \#151495.

$3 \mathrm{pp}$. Voice $\mathrm{w} / \mathrm{piano}$ acc.

Watermark not present.

Dating: Wolfe II, 680, \#6947A; II, 623, \#6377.

31) The musical magazine. Being a collection of the most modern \& favorite songs, airs, marches, \&c. Taken from the works of the most celebrated authors and adapted to the voice, bass, \& key'd instruments. To be continued. Boston: G. Graupner, 3 vols. [1802-
03]. Catalog \#409850 
$96 \mathrm{pp}$. Voice w/piano or harp acc., 2 voices w/bass accompaniment, and piano solo. Full list of songs in Wolfe II, 625-6.

Arranged for flute: The shipwreck'd seamans ghost; Ah can I cease to love her; Tom Tackle; As I wept in sleep;

Arranged for guitar: As I wept in sleep; When pensive I thought of my love. A favorite song in Blue Beard.

Arranged for two guitars: A prey to tender anguish.

Arranged for the flute or violin: The soldier's adieu; A new ode sung by Mr. Eaton at the celebration of the anniversary of American Independence Boston July 4th 1802.

Watermark not present.

Dating: Wolfe, 625-6, \#6378.

32) Oh ever in my bosom live. A favorite duett in the grand pantomime ballet of Oscar and Malvina. [In the Musical Magazine, vol. II, 49] (Boston: Gottlieb Graupner, 1802-3).

$1 \mathrm{p}$. Voice (duet) w/piano acc. Composed by George Reeve.

Watermark not present.

Dating: Wolfe II, 625; 725, \#7370.

33) General Washington's march. Boston: G. Graupner [ca. 1803]. Catalog \#73975.

1 p. Piano solo, followed by Yankee Doodle.

Pub. no. 34. Page no. 114 in 1.h. cor.

Watermark not present.

Dating: Wolfe, III, 940, \#9626B.

34) The Wish. [by] T. Thompson, Baltimore: J. Carr [ca. 1803].

2 pp. Voice w/piano acc. Composed by Thomas H. Thompson.

Watermark not present.

Dating: Wolfe, III, 910, \#9365.

35) [Jesu saviour of my soul] Hymn. MS. [From Sacred Harmony. A selection of airs, duos, trios, \&c. Arranged for the organ, piano forte or harp. Philadelphia: Carr \& Schetky
[1803-04]]. Catalog \#150300-12.

2 pp. Voice w/piano acc.

Dating: Wolfe II, 450, \#4626A; II, 767-8, \#7722.

36) [Farewell Bessy. Music and words by Thos. Moore, Esqr. New York: J. \& M. Paff] (No title provided ) MS. [1803-07]]. Catalog \#150300-12.

2 pp. Voice w/piano acc.

Dating: Wolfe II, 581.

37) The Nightengale. A collection of the most popular ancient and modern songs set to music. Selected by Samuel Larkin. Portsmouth: William and Daniel Treadwell, 1804.

Catalog \#189903.

$288 \mathrm{pp} .109$ song lyrics and melody of one song which includes two treble parts. Contents given in Wolfe, II, 641.

Dating: Wolfe II, 641, \#6534.

38) The timid tear. The words by T. Moore Esqr. Music by A. Berry Esqr. Philadelphia:

G.E. Blake [1804?]. Catalog \#151501.

2 pp. Voice w/piano acc. Composed by Augustus Berry. 
Dating: Wolfe I, 42, \#444.

39) A favourite selection of music. Adapted to the piano forte. Consisting of the newest and most fashionable songs, airs, marches, \&c., comic and sentimental. By O. Shaw and H. Mann. Dedham: H. Mann, 1806. Catalog \#489065.

32 pp. Voice w/piano acc. and piano solo.

Contents: pp. 2-3 Address to a tuft of violets, Shaw; p. 4 Bonaparte's grand march; Gen. Abercrombie's march; p. 5 Tink a tink, Kelly; pp. 6-7 Tears that exhale, T. Andrews; p. 8 $O$, listen to the voice of love, Hook; p. 9 Drink to me only, Jackson; p. 10-11 Felton's gavot. With variations; pp. 12-13 Poor Emma; p. 13 Air, Shaw; p. 14 Unmoved I'll brave the stormy sea, Reeve; p. 15-16 The Persian maid, W.E. Heather; p. 16 Poor Richard, Carr; p. 17 Adieu my liberty; p. 18-19 'Tis only no harm to know it, you know, Shield; p. 20 Bonny doon, a favorite Scotch song; p. 21 [untitled], Storace; New century hornpipe; p. 22-23 The miller's daughter, Hook; p. 24 London, T. Swan; A favorite rondeau; p. 2526 She lives in the valley below, Hook; p. 26-27 Resignation, Shaw; p. 28 I owe you one, Arnold; p. 29 A favorite march in The demolution of the bastile, Elfort; pp. 30-31 The cottage in the grove, Hook; p. 31 Hymn, Shaw.

Dating: Wolfe, II, 785, \#7884.

40) Rudiments of the art of playing on the piano forte, containing elements of music, preliminary remarks on fingering with examples, thirty fingered lessons and a plain direction for tuning. Arranged by Gottlieb Graupner. Boston: G. Graupner [1806]. Catalog \#150300-12.

$40 \mathrm{pp}$. Piano instructions and lessons include examples from Graupner, Handel, Corelli, Pleyel, Hook, Scarlatti, Haydn, and J.C. Bach.

Dating: Wolfe I, 324, \#3202A.

41) The Portuguese hymn. On the nativity. With an English translation. [n.p., n..d.; 18067?] Catalog \#150308.

$2 \mathrm{pp}$. Voice w/bass line acc. and 3-part chorus w/piano acc.

Followed on p. 2 by The Sicilian Hymn. (3 voices w/piano acc.).

Identical to imprint published by Carr \& Schetky (Wolfe I, 3, \#23C).

Dating: Wolfe I, 3 , \#27.

42) O sing sweet bird or the captive to his linnet sung by Mr. Incledon in the wandering melodist. Philadelphia: Carr \& Schetky and sold at the following Music StoresBaltimore: J. Carr; Philadelphia: G. Blake; New York: J. Hewitt; Boston: F. Mallet [1806-
07].

2 pp. Voice w/piano acc. Composed by Joseph Mazzinghi.

The imprint is engraved on a blank sheet on the opposite side of the music, the recto of page 3. It does not include the last two establishments given by Wolfe but in other respects the copy conforms to this one.

On p. 3 above the title and first page of music: "No. 97 of the Musical Journal--Vocal Section--being the commencement of the Fitth Volume which will be completed in 24 Weekly Numbers as usual." Originally published vol. 5, no. 97, pp. 3-5 by Carr in
Philadelphia, 1803-4.

Dating: Wolfe II, 551, \#5670C.

43) Ah, what is the Bosom's commotion, Sung by Mr. Kelly, 
at the Theatre Royal Drury Lane, in the Grand Dramatic Romance of the Forty Thieves, composed by Ml. Kelly. Philadelphia: G.E. Blake [1807?].

$2 \mathrm{pp}$. Voice w/piano acc.

Dating, Wolfe, II, 464, \#4741.

44) Ah! What is the bosom's commotion. MS. [Sung by Mr. Kelly at the Theatre Royal, Drury Lane, in the grand dramatic romance of The Forty Thieves. Composed by M1.

Kelly. Philadelphia: G.E. Blake [1807?]]. Catalog \#150300-12.

4 pp. voice $w /$ piano acc.

Dating: Wolfe II, 464, \#4741.

45) Far Far from me my lover flies. In the Weathercock. Composed by M.P. King. New York: J. \& M. Paff [1807?]. Catalog \#150304.

2 pp. Voice w/piano acc.

Missing the initials W.P. in the r.h. cor. of p. 2.

Dating: Wolfe, II, 485, \#4992.

46) The farewell. Written by Robert Burns. The music arranged by Haydn. Philadelphia:

G.E. Blake [1807-1808]. Catalog \#151509.

$2 \mathrm{pp}$. Voice w/piano acc. in D minor. Arranged for two flutes or clarinets in A minor.

Dating: Wolfe I, 353, \#3497.

47) I have a heart. A favorite ballad. With an accompaniment for the piano forte. As sung by Mrs. Warren. Composed by Mr. G. Gray. Philadelphia: G.E. Blake [1807-1808].

Catalog \#151507.

$2 \mathrm{pp}$. Voice w/piano acc.

Dating: Wolfe I, 325, \#3205.

48) The day of marriage. Sung with applause by Mrs. Hodgkinson. Philadelphia: John Aitken [1808-11]. Catalog \#151489.

$2 \mathrm{pp}$. voice $\mathrm{w} /$ piano acc.

Dating: Wolfe, I, 239, 2358A.

49) O hie thee home will. A Favorite Scotch Ballad Sung with universal applause by Mrs.

Oldmixon composed by J. Sanderson. New York: J. Hewitt [1809].

$2 \mathrm{pp}$. Voice w/piano acc. Composed by James Sanderson

Wolfe, II, p. 774, \#7792.

50) Ah! what is the bosom's commotion, sung by Mr. Jacobs in the Grand Dramtic

Romance of the Forty Thieves composed by M. Kelly. Philadelphia: G. Willig [1809?].

2 pp. Voice w/ piano acc. Composed by Michael Kelly

Copy of Blake's edition of [1807?] in most details.

Dating: Wolfe, II, 464, \#4743.

51) The favorite dance in the grand pantomime of The Forty Thieves. New York: J.

Hewitt [1809?].

2 pp. piano solo. Composed by Michael Kelly.

Dating: Wolfe, II, 466, \#4775. 
52) Snowy rose go deck my fair. Sung by Miss Lyon, at the Theatre Royal Drury Lane, in the favorite opera of Kais, or Love in the deserts. Composed by Mr. Braham. Philadelphia: G.E. Blake [1809?]. Catalog \#150312.

2 pp. Voice w/piano acc.

Dating: Wolfe I, 123, \#1202.

53) The coronach. A funeral song from the Lady of the Lake. music by Dr. John Clarke of Cambridge. Philadelphia: G. Willig [ca 1810]. Catalog \#151488.

2 pp. Voice $w /$ piano acc.

Reissue from publication of the Journal of Musick, Baltimore: LePelletier, 1810.

Dating: Wolfe, II, 183, \#1827A.

54) Little Winny Wilkins. A favorite song by Mr. Cherry composed with an accompaniment for the flute, piano forte or harpe by Mr. Whitaker. Philadelphia: G. Willig [ca 1810]. Catalog \#151493.

$4 \mathrm{pp}$. Voice w/piano or harp acc. Flute part is cued in small notes in portions of the piece. No separate flute part.

Dating: Wolfe, III, 957, \#9826A.

55) Come take the harp. A Canzonett written by Thomas Moore Esqr., composed by Sir J. Stevenson Mus: Doc. Philadelphia: G.E. Blake [1810-14].

3 pp. Voice w/piano acc., 3 verses. Composed John Andrew Stevenson.

Dating: Wolfe II, 850, \#8662.

56) Dulce Domum. Composed and sung with great appause [!] By Mr. Braham. Philadelphia: G.E. Blake [1810-14]. Catalog \#150300.

4 pp. Voice w/piano acc.

Dating: Wolfe I, 111, \#1081.

57) Now at moonlight's fairy hour. A duett, for two voices. MS. [Composed by Thomas Thompson] [?Philadelphia: G.E. Blake, 1810-14]. Catalog \#150300-12.

$6 \mathrm{pp}$. Two voices $\mathrm{w} / \mathrm{harp}$ or piano acc.

Dating: Wolfe II, 909, \#9354.

58) Twelve little ballads and a favorite lesson. Arranged in a familiar style for juvenile performers on the piano forte. Philadelphia: G. E. Blake, vol. 2 [1810-14]. Catalog \#151527.

$29 \mathrm{pp}$. Voice w/piano acc. and piano solo.

Contents: P. 17: Life let us cherish by Mozart; p. 18: The blue bell of Scotland. A favorite Scotch ballad; p. 19: Cynthia's cottage; p. 20: The sailor's wife; p. 21: When the rosy morn appearing from the opera of Rosina. Composed by Shield; p. 22: The twin roses. A favorite song in Adrian and Orrila. Composed by M. Kelly; p. 23: Bounding billows. Written by Mrs. Robinson, in crossing from Dover to Calais; p. 24: Major Andre's complaint; p. 25: I have a silent sorrow here. Sung with great applause by Mrs. Merry in the opera of the Stranger. Composed by A. Reinagle.; p. 26: The woodlands. A favorite duet. Composed by Harrington; p. 27: Ere around the huge oak; p. 28: The woodman. Sung by Mr. Jefferson in the Forty Thieves. Composed by Mr. Kelly.; p. 29: Dance of naiads [from the Forty Thieves].

Dating: Wolfe, I, 39, \#429 (unlocated by Wolfe). 
59) Dulce domum. Composed and sung by Mr. Braham. Philadelphia: G. Willig [1810-

15]. Catalog \#151545.

4 pp. Voice w/piano acc.

In lower margin p. 1: D.D.4.

Dating: Wolfe I, 112, \#1082.

60) [The] Shawl dance. MS. [As dance'd at the New Theatre by Master Whale, The infant Vestris. For the piano forte or harp in Eb. Philadelphia: G. Willig [1810-15]]. Catalog \#150300-12.

5 pp. Piano or harp solo.

Dating: Wolfe II, 795, \#7998.

61) Andantino. (for piano solo) Followed by The Waving Willow. MS. [A favourite song. Boston: G. Graupner, [1811?]]. Catalog \#150300-12.

2 pp. Voice w/piano acc. Composed by William Shield.

Dating: Wolfe II, 810, \#8208.

62) The fall of Paris. A favorite quick step. As performed by His Royal Highness the Duke of Gloucesters band. And adapted for the harp, or piano forte. New York: J. Willson [1812]. Catalog \#374727.

2 pp. Harp or piano solo.

Dating: Wolfe I, 273, \#2736B.

63) Hornpipe. MS. [Danced at the Olympic Theatre by Mr. Drummond.] From Pelissier's

Columbian melodies. Number 7 [p. 70]. Philadelphia: G. Willig [1812]. Catalog \#15030012.

1 p. Piano solo.

Dating: Wolfe II, 674, \#6897; II, 676-7, \#6923.

64) Brazilian waltz. With an accompaniment ad libitum for the flute, clarinet, flagiolet, and violin. New York: E. Riley [1812?]. Catalog \#150311.

$7 \mathrm{pp}$. Flute w/piano acc. Composed by Peter Weldon.

Dating: Wolfe III, 949, \#9732.

65) Love's young dream. Oh! the days are gone. n.p. [From A selection of Irish melodies. With symphonies and accompaniments by Sir John Stevenson, Mus. Doc., and characteristic words by Thomas Moore, Esqr. No. 4] [Baltimore: J. Carr, 1812?]. Catalog

$2 \mathrm{pp}$. Voice w/piano acc.

Marked pp. 48-49.

Dating: Wolfe, II, 864, \#8831A; 873, \#8942.

66) The Minstrel's harp. An arietta, from the Lay of the last Minstrel; with an accompaniment for the harp, or piano forte, composed by John Clarke, Mus. Doc.

Philadelphia: G.E. Blake. [1812?]. Catalog \#150301.

$3 \mathrm{pp}$. Voice $w /$ harp or piano acc.

Dating: Wolfe I, 185, \#1845. 
67) [She's gone! A daughter's gone to save] Recitative and pollacca. Sung by Mrs. Green. In the favorite opera of the Exile. Composed by J. Mazzinghi. Philadelphia: G.E. Blake [1812?]. Catalog \#150310.

$5 \mathrm{pp}$. Voice w/piano acc.

Dating: Wolfe, II, 555, \#5722.

68) Washington's march. As performed at the New Theatre. Philadelphia. Philadelphia: G. Willig [1812?].

2 pp. Piano solo.

Followed on p. 2 by Quick step, composed by R. Taylor.

Dating: Wolfe III, 902, \#9281; 939, \#9617.

69) Decatur's victory. MS. [A favorite new song. Written by W. Strickland. Philadelphia;

G.E. Blake [1812-13]]. Catalog \#150300-12.

2 pp. voice $w /$ piano acc.

Dating: Wolfe I, 240, \#2370.

70) Hull's victory. A new patriotic song. Sung with great applause by Mr. Hardinge at the Philadelphia theatre. Written by Joseph Hutton. Composed by John Bray. Philadelphia: G. Willig. [1812-13]. Catalog \#422918.

2 pp. Voice w/piano acc.

Dating: Wolfe I, 131-2, \#1301.

71) The Duke of Yorks troop and 2 waltz's. New York: E. Riley [1812-18]. Catalog \#374727.

2 pp. Piano solo.

The two waltzes on p. 2 are each headed "Ulmer."

Dating: Wolfe I, 257, \#2597.

72) The American patriotic song book, a collection of political, descriptive, and humorous songs of national character and the production of American poets only, interspersed with a number set to music. Philadelphia: W. M'Culloch. 1813. Catalog \#110009.

108 pp. 18 songs are set to a melody line, three of which include two parts suitable for playing on the piano. Contents given in Wolfe I, 13.

Dating: Wolfe I, 13, \#122A.

73) Too late I staid. MS. [From Gilfert: Four Songs. New York: E. Riley [1813]].

Catalog \#150300-12.

$2 \mathrm{pp}$. Voice w/piano acc.

Dating: Wolfe II, 310, \#3071.

74) The cypress wreath. From Rokeby. MS. [Written by Walter Scott. Composed by John Bray. Philadelphia: G.E. Blake [1813?]]. Catalog \#150300-12.

2 pp. Voice w/piano acc.

Dating: Wolfe I, 130, \#1285.

75) A weary lot is thine fair maid! From Rokeby, written by Walter Scott Esqr. Composed by C. Gilfert. Philadelphia: G.E. Blake [1813-14]. Catalog \#150302.

2 pp. Voice w/piano acc.

Dating: Wolfe I, 311, \#3085. 
76) Will you come to the bow'r. By Thos. Moore Esqr. With eight variations for the piano forte composed by J. Eckhard, Jr. Philadelphia: G. E. Blake [1813-14]. Catalog \#151499. 5 pp. Piano solo.

Dating: Wolfe, II, 590, \#6057.

77) College Hornpipe. Followed by Fishers Hornpipe. From Two sets of cotillions and two hornpipes. [New York, [1814]]. Catalog \#374727.

1 p. Piano solo.

Upper r.h. cor. p. 10.

Dating: Wolfe I, 208, 2010. Compare the edition published by John Paff [1814] (Wolfe II, 786, \#7989.)

78) When death's gloomy angel was bending his bow. Written for the first anniversary of the Washington benevolent society of Pennsylvania. By a member. The music arranged by R. Taylor. Philadelphia: G. Willig [1814]. Catalog \#151562.

2 pp. Voice w/piano acc.

Dating: Wolfe II, 823, \#8362.

79) The celebrated dance in Tekeli. Arranged as a rondo for the piano forte by Mr. Holst. Second Edition. Philadelphia: G.E. Blake [1814?]. Catalog \#151511.

4 pp. Piano solo. Composed by James Hook.

Dating: Wolfe I, 399, \#4007.

80) Sicilian dance, as Performed at the Libraries of Brighton, Margate \&c. arranged as a Rondo for the Piano Forte by T. Costellow. Philadelphia: G.E. Blake [1814-17].

4 pp. Piano solo. Arranged by Thomas Costellow.

Stamped: Depository of Arts Bourne's Broad359way [active 1827-32, acc. to Dichter \& Shapiro, 174]

Dating: Wolfe I, 219 , \#2137.

81) Jessie the flow'r o' Dumblane. A favorite Scottish song written by R. Tannahill. Composed, \& dedicated to his friend James McFarland. London. By R.A. Smith.

Philadelphia: T. De Silver [1815?]. Catalog \#151515.

3 pp. Voice w/piano acc. in B-flat major. Arranged for German flute in D major.

Dating: Wolfe II, 824, \#8372.

82) Love among the roses. With an additional verse-Written for this work. By a gentleman of Baltimore. Philadelphia: G.E. Blake [1815?]. Catalog \#150307.

2 pp. Voice w/piano acc. Composed by John Colston Doyle.

At head of title: No. 4 of Blake's Musical Miscellany-Copy Right Secured. Marked pp. 10-11.

Dating: Wolfe, I, 253, \#2555; I, 87, \#860.

83) Wreaths for the chieftain. Written by L.M. Sargent Esqr. and sung by Mr. Huntington in the Stone Chapel, Boston, at the celebration of peace with Great Britain, and the birth day of Genl. Washington, Feb. 22nd, 1815. Adapted to a favorite air of Sanderson, from the Lady of the Lake, by F. Granger. Boston: G. Graupner [1815?]. Catalog \#151560. 3 pp. Voice w/piano acc. Composed by James Sanderson.

Pub. no. 230. 
Dating: Wolfe II, 77, \#7827.

84) Ah! vous dirai, je maman. Par Cordon. MS. [A favorite French air. With variations for the harp composed by Cardon fils. Philadelphia: G.E. Blake [1815-17]]. Catalog \#150300-12.

6 pp. Piano or harp solo.

Dating: Wolfe I, 149-50, \#1520.

85) The Tyrolese song of liberty. By Thomas Moore Esqr. Philadelphia: G. Willig [18151818]. Catalog \#151512.

$2 \mathrm{pp}$. Voice w/piano acc.

Dating: Wolfe II, 588, \#6039.

86) Star spangled banner. Philadelphia: A. Bacon \& Co. [1816?]. Catalog \#374727.

2 pp. Voice with piano acc. in $C$ major. Melody arr. for flute in $D$ major.

Dating: Wolfe II, 821, \#8345A.

87) A Canadian boat song. Philadelphia: G. Willig [1816-1817].

1 p. 3 voices w/piano acc.

Dating: Wolfe, II, 580, \#5939.

88) The minute gun at sea, A favourite duett composed by M.P. King. Philadelphia: Geo. Willig [1816-17].

4 pp. Two voices w/piano acc. Composed by Matthew Peter King. Drum parts doubling the piano are cued in the bass part.

Dating: Wolfe II, 487, \#5018.

89) The minute gun at sea. MS. [A favorite duett. By M.P. King. Philadelphia: G. Willig [1816-17]]. Catalog \#150300-12.

4 pp. Voice w/piano acc. Followed on p. 4 by Waltz (for piano solo).

Dating: Wolfe II, 487, \#5018.

90) I was a wild and wayward boy. MS. [From Rokeby. Written by Walter Scott, Esqr. Composed by G. Kiallmark. Philadelphia: G. Willig [1816-18]]. Catalog \#150300-12.

1 p. Voice w/piano acc.

Dating: Wolfe II, 482, \#4956.

91) Song to the memory of Mozart. Addressed to the Eolian Harp. Duetto written by D. Thompson. Philadelphia: G. Willig [1816-18].

3 p. Voice w/piano acc. Set to the tune "Bei Maennern" from Die Zauberflote by W. A. Mozart.

Dating: Wolfe II, 614, \#6304.

92) The beautiful maid. A favorite ballad. As sung \& composed by Mr. Braham. New York: Wm Dubois [1817]. Catalog \#374727.

4 pp. Voice w/piano acc.

Dating; Wolfe I, 107, \#1041.

93) The beautiful maid. A Favorite Ballad as Sung \& Composed by Mr Braham. New York: Wm Dubois [1817]. 2nd copy. 
4 p. Song w/piano acc. Composed by John Braham.

Dating Wolfe, I, 107, \#1041.

94) The freemason's library and general Ahiman Rezon, containing a delineation of the true principles of freemasonry, speculative and operative, religious and moral, compiled from the writings of the most approved authors. With notes and occasional remarks. By Samuel Cole, P.M., of Concordia \& Cassia Lodges, P.G.S. of the G.L. of Md., K.T., K.M, \&c. Baltimore: Benjamin Edes, 1817. Catalog \#70668.

$332 \mathrm{pp} .9$ songs with music for voice, two- and three-parts.

Contents: 214-15 [Mark master's song]; 216-17 Mark master's song. Smith, J.S.; 230-33 Most excellent master's song; 254-56 [Royal arch song]. Cole; Appendix: 83-5 [When earth's foundation]. Arne; 85-7 Past master's song; 88-90 Give thanks to God most high; 90-91 [Unto the great God belong]; 91-93 Knight templar's song.

Dating: Wolfe I, 284-85, \#2860.

95) The harp, or selected melodies from authors eminent for genius and taste. Dedicated to the lovers of music and song. Greenfield, Mass.: Denio \& Phelps. 1817. Catalog \#49957.

$16 \mathrm{pp} .16$ song lyrics and melodies.

Contents: $3-4 \mathrm{O}$ think not my spirits are always as light. Stevenson; 4 Spring; 5-6 [Tomorrow]. Smart; 7-8 Saul before battle; 8 Days of youth; 9-10 [Jessie the flower o' Dumblane]. Smith, R.A.; 10 Modern Greek song; 11 I sold a guiltless negro boy. Moulds; 12 Life let us cherish. Naegeli; 12-13 My Nanie O; 14-15 Mary's dream. Relfe; 15 The virtuous man; 15-16 The bright orb of day; 16 The traveller.

Dating: Wolfe I, 345-6, \#3435.

96) Latour's favorite waltz. New York: W. Dubois [1817]. Catalog \#151544.

2 pp. Piano solo.

Dating: Wolfe II, 518, \#5309.

97) A soldier's gratitude. A favorite song sung by Mr. Nichols composed by H.R. Bishop. New York: W. Dubois [1817].

2 pp. Voice \& piano. Composed by Henry R. Bishop.

Dating: Wolfe, I, 75, \#794.

98) Sound the loud timbrel. Air, Avison. For three voices. Sung at the oratorios. New York: Wm. Dubois [1817]. Uncataloged (Music book marked Harriet A. Stanton).

3 pp. 3 voices w/piano acc. Composer: Charles Avison.

At head of title: Miriam's song.

Below title: "And Miriam, the prophetess, the sister of Aaron, took a timbrel in her hand and all the women went after her with timbrels and with dances." -EXOD. XV, 20.

Bottom of p. 1: Sold by C. B. De Riemer \& Co., Auburn.

Stamp: Sold by J.L. Hewitt / 137 Broadway / New York.

At foot of first page 3 : indicating the number of pages.

Dating: Wolfe I, 32, \#360.

99) Ye banks and braes of bonny doon, a favorite Scotish air, arranged \& varied by W. Ling. Philadelphia: A. Bacon [1817].

2 pp. Piano solo. Composed by William Ling.

Plate number 59. 
Dating: Wolfe II, 525, \#5388.

100) Be mine dear maid. A ballad. From Guy Mannering. Composed by John Davy. Philadelphia: G. Willig [1817?]. Catalog \#151548.

2 pp. Voice w/piano.

Dating: Wolfe I, 234, \#2297.

101) Blue eye'd Mary. [With variations for the piano forte by an Amateur. New York:

Geib \& Co. [1817?]]. Catalog \#374727.

8 pp. (title page missing). Piano solo.

Dating: Wolfe I, 10, \#90.

102) A favorite waltz. Composed by M.A. Mozart. Philadelphia; A. Bacon \& Co. [1817?]. Catalog \#374727.

2 pp. Piano solo.

Pub. no. 25.

Dating: Wolfe II, 616, \#6331A.

103) The Rose-bud of Summer, A ballad, as sung by Miss Stephens, at the Theatres Royal, London composed by Sir John Stevenson Mus. Doc. Philadelphia: G. Balls [1817?].

$3 \mathrm{pp}$. Voice w/piano acc. in A major. Melody arr. for flute or flageolet in D major.

Dating: Wolfe II, 851, \#8677.

104) Stantz waltz. With variations for the piano-forte or harp. P.K. Morans Philadelphia: A. Bacon, and Valotte \& Lété [1817?]. Catalog \#374727.

5 pp. Piano solo.

Dating: Wolfe II, 598, \#6122A.

105) Cadet's march. For the piano forte. New York: W. Dubois [1817-1818]. Catalog \#151504.

2 pp. Piano solo.

Includes Downshire quickstep on p. 2.

Dating: Wolfe, I, 100, \#984A.

106) The Copenhagen waltz. With variations by T.L. Holden. New York: Wm. Dubois [1817-18]. Catalog \#374727.

3 pp. Piano solo.

Reissue of publication by John Paff. [1811-17].

Dating: Wolfe I, 390, \#3894A.

107) The cottage rondo. Composed by M. Holst. New York: W. Dubois [1817-18]. Catalog \#374727.

4 pp. Piano solo.

At head of title, a scrolled engraving, showing an eagle. This imprint is within it, and the title is spread across a scroll held by its beak.

Dating: Wolfe I, 391, \#3904A.

108) The cottage rondo. Composed by M. Holst. New York: W. Dubois [1817-18].

Uncataloged (Music book marked Harriet A. Stanton). Second copy. 
4 pp. Piano solo.

At head of title, a scrolled engraving showing an eagle. The imprint is within it and the title is spread across a scroll extended from the eagle's beak.

Reissue of publication by Paff, 1811-17.

Dating: Wolfe I, 391, \#3904A.

109) The cuckoo. A favorite song. New York: Wm. Dubois [1817-18]. Uncataloged (Music book signed Harriot A. Stanton).

2 pp. Voice w/piano acc.

Reissue of publication by John Paff, [1811-17].

Dating; Wolfe I, 399, \#4004A.

110) Favorite Swiss waltz. With variations for the harp or piano forte, P.K. Moran. New York: Wm. Dubois [1817-18]. Catalog \#374727.

3 pp. Harp or piano solo.

Reissue of publication by John Paff [1817?].

Dating: Wolfe II, 599, \#6127A.

111) I'll love thee ever dearly. Sung by Mr. Taylor. From the operatic anecdote Frederick the Great. Composed by T. Cooke. Philadelphia: G. Willig [1817-18]. Catalog \#151505. 3 pp. Voice w/piano acc.

Dating: Wolfe I, 211 , \#2062.

112) 'Tis the last rose of summer. A favorite Irish melody. Words by Thos. Moore Esqr. Arranged by Sir I.A. Stevenson, Mus. Doc. New York: Wm Dubois [1817-18]. Catalog \#374727.

2 pp. Voice w/piano acc.

Reissue from publication by John Paff, 1815 ?

Dating: Wolfe II, 861, \#8800A.

113) A prey to tender anguish. Composed by Dr. Haydn. With an accompaniment for the harp or piano forte by J.F. Bohlius. New York: W. Dubois [1817-18]. Catalog \#374727. 2 pp. Voice w/piano acc.

Lower part of p. 2 is missing.

Dating: Wolfe I, 356, \#3533A.

114) The Queen of Prussia's and the Russian waltz. Arranged for the piano forte by F.C. Panormo, Junr. Boston: G. Graupner [1817-19]. Catalog \#374727.

2 pp. Piano solo.

Pub. no. 100.

"The Russian Waltz" appears in the lower part of p. 3.

Dating: Wolfe I, 388, \#3869.

115) The favorite Scotch air Auld langsyne. With variations for the piano forte or harp. Composed by D. Ross. New York: W. Dubois [1818]. Catalog \#374727.

1 p. (pp. 2-5 piano or harp part missing). Voice w/piano acc.

Dating: Wolfe II, 753, \#7573.

116) Flow on thou shining river. Portugese [!] air. Words by T. Moore Esqr. Arranged by Sir John Stevenson. New York: W. Dubois [1818]. Catalog \#374727. 
2 pp. Voice w/piano acc.

Dating: Wolfe II, 855, \#8726.

117) The popular air Eveleen's bower. From Moore's Irish melodies. Arranged with variations for the piano forte by J. B. Logier. New York: W. Dubois [1818]. Catalog
$\# 151500$.

7 pp. Piano solo.

Dating: Wolfe II, 853, \#8701.

118) La retour de Wicklow. Aria pastorale, pas seul \& waltz. For the piano-forte.

Composed \& dedicated to Miss Stowell. By T. Bennison. New York: W. Dubois [1818].

Uncataloged (Music book marked Harriet A. Stanton).

6 pp. Piano solo.

In lower margin of t.p. the number 6 indicates page length.

Dating: Wolfe I, 48, \#521A.

119) The storm rondo for the piano forte. Composed by D. Steibelt. New York: Wm.

Dubois [1818]. Uncataloged (Music book marked C.A. Stewart).

11 pp. Piano solo. Composed by Daniel Steibelt.

Dating: Wolfe II, 844, \#8586.

120) Take this rose, an admired song sung with much applause by Mr. Keene; composed $\&$ arranged for the Piano forte, by T. V. Wiesenthal. Philadelphia: Bacon \& Co. [1818]. $3 \mathrm{pp}$. Voice w/piano acc. Composed by Thomas Van Dyke Wiesenthal.

At head of title: American Musical Miscellany No. 4. Plate no. 107.

Dating: Wolfe III, 966, \#9916.

121) Fly to the desert. From Lalla Rookh. Composed by Thomas Moore Esqr.

Philadelphia: G. Willig [1818?].

2 pp. Voice w/piano acc. Composed by George Kiallmark.

Dating: Wolfe II, 481, \#4951.

This sheet is identical to one published in 1818 ? by George Blake.

122) Saxon air! Introduction and variations for the piano forte. Performed by Mr. Etienne at Mr. Gilles' concert. Composed by J. B. Cramer. Philadelphia: G. Willig [1818?].

Catalog \#151497.

$11 \mathrm{pp}$. Piano solo.

Dating: Wolfe I, 223, \#2181.

123) Richmond's march. For the piano forte. New York: E. Riley [ca. 1818]. Uncataloged (Music book marked Harriet A. Stanton).

2 pp. Piano solo.

Followed on pp. 1-2 by "The caravan march in The forty thieves" and on p. 2 by "A favorite troop."

On p. 2 lower r.h. cor.: Richmond \& Caravan March, 2.

Dating: Wolfe II, 734, \#7474A.

124) Strike the cymbal. As performed at the oratorios in St. Paul's. Composed by Pucitta. New York: E. Riley [ca. 1818]. Uncataloged (Music book signed Harriot A. Stanton).

4 pp. 3 part chorus w/piano acc. 
Dating: Wolfe II, 715, \#7251B.

125) The favorite Scotch air Auld lang syne, with Variations for the piano forte or harp composed by Dr. Ross. Philadelphia: G. Willig [1818-19].

2 p. Voice w/piano or harp acc. Composed by Daniel Ross

Dating: Wolfe, II, 754, \#7574.

126) The favorite Vienna waltz. Philadelphia: G. Willig [1818-19]. Uncataloged (Music book signed Harriot S. Stanton).

1 p. Piano solo.

Dating: Wolfe II, 922, \#9477.

127) The Hungarian waltz. As danced by Mrs. Wallack. New York: E. Riley [1818-20]. Uncataloged (Music book signed Harriot A. Stanton).

1 p. Piano solo.

Dating: Wolfe I, 432, \#4417.

128) The knight errant. MS. [Written and composed by Hortencia, the late Queen of Holland]. Translated from the French by Walter Scott. [Philadelphia: G.E. Blake [1818201]. Catalog \#150300-12.

1 p. (one or two pp. missing). Voice w/piano acc.

Dating: Wolfe I, 425, \#4340.

129) Mary, the maid of the green! A ballad sung with great applause by Mr. Lamb composed by J. Monro. New York: J. A. and W. Geib [1818-20].

3 pp. voice \& piano. Composed by John Monro.

There are indications in the piano part for "Violoncello solo" and flute.

Dating: Wolfe, II, 576, \#5905.

130) The morning star. A dance. New York: E. Riley [1818-20]. Uncataloged (Music book signed Harriot A. Stanton).

1 p. Piano solo.

Dating: Wolfe II, 600, \#6144.

131) Oh Nanny wilt thou gang with me. A favorite Scotch ballad. Sung with unbounded applause by Mrs. French. Philadelphia: G.E. Blake [1818-20]. Catalog \#151540.

2 pp. Voice w/piano acc. Composed by Charles Thomas Carter.

Dating: Wolfe I, 170, \#1698.

132) Be mine tender passion! A beautiful song in the opera of the Haunted Tower.

Composed by S. Storace. New York: J.A. \& W. Gieb [!], [1818-21]. Catalog \#151516.

$7 \mathrm{pp}$. Voice w/piano acc.

Dating: Wolfe II, 885, \#9087.

133) The Duke of York's march. New York: J.A. \& W. Geib [1818-21]. Uncataloged (Music book marked Harriet A. Stanton).

2 pp. Piano solo in $F$ major, melody arranged for flute in $\mathrm{G}$ major.

Dating: Wolfe I, 257, \#2591. 
134) The favorite German serenading waltz. Arranged for the piano forte. New York: W. Dubois [1818-21]. Catalog \#151506.

2 pp. Piano solo.

Wolfe I, 300, \#2974.

135) The favorite German serenading waltz. Arranged for the piano forte. New York: W. Dubois [1818-21]. Catalog \#374727. 2nd copy.

2 pp. Piano solo.

Dating: Wolfe I, 300, \#2974.

136) The gallant troubadour. A celebrated French romance. Arranged for the piano forte. To which is added English words by S. of New Jersey. New York: J.A. \& W. Geib [181821]. Catalog \#151508.

Voice w/piano acc.

On p. 1: Engraved by T. Birch.

Dating: Wolfe II, 919, \#9447.

137) Louden's bonny woods and braes! A favorite Scotch melody as sung by Mrs. Moran arranged by P.K. Moran. The words by R. Tannahill. New York: W. Dubois [1818-21]

2 pp. Male and female duet w/piano acc. Arranged by Peter K. Moran.

Dating: Wolfe II, 596, \#6106.

138) My mother bids me bind my hair. A favorite canzonet. Composed by Dr. Haydn.

New York: W. Dubois [1818-21]. Catalog \#151510.

2 pp. Voice w/piano acc.

Dating: Wolfe, I, 355, \#3515.

139) Oh! remember the time. A Spanish air. Arranged with English words by Thomas

Moore Esqr. New York: J.A. \& W. Geib [1818-21]. Catalog \#374727.

$3 \mathrm{pp}$. Voice $\mathrm{w} / \mathrm{piano}$ acc.

In lower margin p. 1: Eng. by Birch.

Dating: Wolfe I, 172, \#1711.

140) The parting pledge. A ballad. Written by Lord Byron, the music composed by John Parry. New York: J. A. and W. Geib [1818-21].

3 pp. Voice \& piano.

Dating: Wolfe, II, 667, \#6818.

141) Where roses wild were blowing. The beautiful Venetian air, La biondina in gondoletta adapted with English words by Henry F. Smith. New York: W. Dubois [181821].

2 pp. Voice \& piano.

Dating: Wolfe, II, 817, \#8309.

142) The minute gun at sea. A favorite duett. Composed by M.P. King. New York: E.

Riley [1818-22]. Uncataloged (Music book signed Harriot A. Stanton).

$4 \mathrm{pp}$. Two voices $\mathrm{w} / \mathrm{piano}$ acc.

Dating: Wolfe II, 487, \#5021A.

143) The Presidents march. For the piano forte. New York: E. Riley [1818-26]. 
1 p. Piano solo.

Dating: Wolfe II, 684, \#6992.

144) Washington's march. New York: E. Riley [1818-26]. Uncataloged (Music book signed Harriot A. Stanton).

1 p. Piano solo.

Dating: Wolfe III, 940, \#9633.

145) The waterman. A dance. New York: E. Riley [1818-26]. Uncataloged (Music book signed Harriot A. Stanton).

1 p. Piano solo.

Dating: Wolfe III, 941, \#9638.

146) Dainty Davie. Ballad. Written by Burns. Arranged for and piano by Kozeluch. Philadelphia: G.E. Blake [1818-27]. Catalog \#151528.

$2 \mathrm{pp}$. Voice $\mathrm{w} / \mathrm{piano}$ acc.

Stamp: Sold at Cole's Music Store Balto.

Dating: Wolfe II, 498, \#5132.

147) Adieu my native land adieu. A favorite song. The accompaniments for the piano forte. Composed by P. K. Moran. New York: E. Riley [1819].

3 pp. Voice w/piano acc. Composed by Peter K. Moran.

Dating: Wolfe, II, 593, \#6084

148) [New Edition] Fresh and strong the breeze is blowing the favorite song in Inkle \& Yarico. Arranged with new Symphonies \& an Accompaniment for the Piano Forte, by P. K. Moran. The two last verses expressly written by S. of New Jersey. New York: W. Dubois [1819].

2 pp. Voice w/piano acc. Composed by Samuel Arnold.

Dating: Wolfe I, 24, \#246.

149) O my Love's like a red rose. A favorite Scotch air as sung by Mr. Howard in Rob Roy Macgregor at the New York Theatre arranged by John Davy. New York: W. Dubois [1819].

2 pp. Voice w/piano acc.

Dating: Wolfe, I, 235, \#2318.

150) A Venetian Air, Arranged with Variations for the Harp or Piano Forte. Dedicated to Miss Ward by P.K. Moran. New York: W. Dubois [1819].

$5 \mathrm{pp}$. Piano or harp solo. Composed by Peter. K. Moran.

At head of music, p. 2: Venetian Girl, P.K. Moran (not indicated in Wolfe).

Dating: Wolfe, II, 599-600, \#6135.

151) Auld Robin Gray. With recitative \& vocal embellishments, as sung with the greatest applause by Mrs. French. Philadelphia: G. Willig [1819?]. Catalog \#151537.

$4 \mathrm{pp}$. Voice w/piano acc.

Dating: Wolfe I, 31, \#349.

152) Auld Robin Gray. with Recitative \& Vocal embellishments as sung with the greatest applause by Mrs. French. Philadelphia: G.E. Blake [1819?]. 
4 pp. Voice w/piano acc.

Blake's Musical Miscellany, \#19.

Dating: Wolfe, I, 31, \#348.

153) Bruce's address to his army. A favorite Scotch song. As sung by Mr. Keene.

Philadelphia: G. Willig [1819?]. Catalog \#151503.

2 pp. Voice $w /$ piano acc.

Dating: Wolfe I, 138, \#1382.

154) The lighthouse written by Thomas Moore, Esqr. composed by J. Wilson.

Philadelphia: G. Willig [1819?].

2 pp. Voice w/piano acc. Composed by Joseph Wilson.

Dating: Wolfe, III, 977, \#10003.

155) Like the gloom of night retiring. With vocal embellishments as sung with the greatest applause by Mrs. French. Composed for the piano forte by Henry R. Bishop. Philadelphia: G. Willig [1819?]. Catalog \#151538.

$5 \mathrm{pp}$. Voice w/piano acc.

Wolfe I, 64, \#679.

156) Like the gloom of night retiring with vocal embellishments as sung with the greatest applause by Mrs. French. Composed for the Piano Forte by Henry R. Bishop.

Philadelphia: G. Willig [1819?].

$4 \mathrm{pp}$. Voice $\mathrm{w} / \mathrm{piano}$ acc.

Dating: Wolfe, I, 64, \#679.

157) The Hungarian waltz. As danced by Mrs. H. Wallack in the admired ballet of Love among the roses. Philadelphia: G.E. Blake [ca 1819]. Catalog \#374727.

2 pp. Piano solo. Followed on p. 2 by The Parisian Waltz.

Dating: Wolfe I, 432-3, \#4424.

158) National melodies, consisting of the most admired airs of England, Ireland, Scotland \& Wales. Arranged as rondos or with variations for the piano forte and an introductory movement to each composed by the most eminent Authors. Norfolk: G. Balls [ca. 1819]. Catalog \#151492.

Contains: pp. 2-3 The brown Irish girl. Arranged by J.B. Cramer; 3- 7 Irish Air.

7 pp. Piano solo.

Dating: Wolfe I, 220, \#2153 and Wolfe II, 634. \#6471.

159) The plough boy. A favorite rondo for the piano forte or harp. As performed on the harp with great applause by Dr. H. at Mr. Nenninger's concert. Composed by J.L. Dussek. Philadelphia: G.E. Blake and New York: R. Meetz [1819-20]. Catalog \#151530. 7 pp. Piano solo.

Dating: Wolfe III, 805, \#8126.

160) A duett for two performers on one piano forte, in which are introduced the Tyrolese air \& Copenhagen Walze as performed by Mr. \& Miss Moran with great applause at the New York Concerts composed \& arranged by P.K. Moran. *Miss Moran was only five years of age when she performed the Primo part of this Duett. New York: W. Dubois [1820]. 
6 pp. Piano, 4 hands. Composed by Peter K. Moran.

Dating: Wolfe, II, 594, \#6096.

161) A duett for two performers on one piano forte. In which are introduced the Tyrolese air \& Copenhagen waltz. As performed with great applause at the New York concerts. Composed \& arranged by P.K. Moran. New York: W. Dubois [1820]. Uncataloged (Music book marked Harriet A. Stanton). 2nd copy.

$7 \mathrm{pp}$. Piano four hands.

On title page: *Miss Moran was only five years of age when she performed the Primo part of this Duett.

Stamp: Depository of Arts / Bourne's / Broad559way.

Dating: Wolfe II, 594, \#6098.

162) Hail to the happy day, sung by Miss Stephens composed by Signor Rossini. N;B; These are English words to the favourite Italian Air "Tu che accendi questo core" sung by Mrs. French at her concerts and particularly arranged for these numbers by B. Carr.

Baltimore: T. Carr [1820].

3 pp. Voice w/piano acc. Composed by Gioacchino Rossini.

Dating: Wolfe II, 758, \#7619.

No. 60 of Carr's Musical Miscellany in Occasional Numbers

163) La ci darem la mano! Duetto. Sung by Sigr Ambrogelli \& Made Fodor in the opera of Il Don Giovanni. Composed by Mozart. New York: W. Dubois [1820]. Catalog $\# 151513$.

4 pp. 2 voices $w /$ piano acc.

Stamp: Sold at G. Willig's Musical Magazine Philad.

Dating: Wolfe II, 608, \#6249.

164) Oh! say not woman's heart is bought. A favorite ballad. Sung with the most rapturous applause by Miss Stephens. Composed by John Whitaker. New York: W. Dubois [1820]. Catalog \#374727.

3 pp. Voice w/piano acc.

Dating: Wolfe III, 959, \#9843.

165) Oh tell me how from love to fly, composed for Miss McCausland by A. Clifton (by permission of the author) Philadelphia: G. Willig [1820].

2 pp. Voice w/piano acc. Composer Arthur Clifton, assumed name of Philip Anthony Corri.

3 copies. At head of title: Entered according to Act of Congress the twenty-first day of November, 1820, by Arthur Clifton of the State of Maryland.

Dating: Wolfe I, 197, \#1943.

166) The sun that lights the roses! A favorite song. As sung by Mr. Pearman with the greatest applause. The words by J.W. Lake, Esqr. The music by Thos. Williams. New York: W. Dubois [1820]. Catalog \#151518.

3 pp. Voice w/piano acc.

Dating: Wolfe III, 970, \#9952.

167) The sun that lights the roses! A favorite song as sung by Mr. Pearman. The words by J.W. Lake, Esqr. the music by Tho. Williams. New York: W. Dubois [1820]. 
3 p. voice \& piano. Composed by Thomas Williams.

Dating: Wolfe, III, 970, \#9952.

168) Auld lang syne. Philadelphia: Geo. Willig [ca 1820]

1 p. Voice w/piano acc. In Twelve little Ballads and a Favorite Lesson (Philadelphia: Geo. Willig).

Dating: Wolfe, I, 30, \#340A.

169) Curly Locks and Little Bo Peep from Twelve little Ballads and a favorite lesson.

Arranged in a familiar manner for juvenile performers on the piano forte. Book I.

Philadelphia: George Willig [ca 1820].

1 p. Voice w/piano acc.

Dating: Wolfe, I, 39, \#430; 228, \#2237.

170) March in Henry the Fourth. n.p. [ca. 1820].

$2 \mathrm{pp}$. Piano solo. A similarity of type font suggested that this music was published by $\mathrm{G}$. Willig.

Dating: Wolfe II, 545, \#5609.

171) Since then I'm doom'd. With variations. MS. [By Latour. Philadelphia: G.E. Blake [ca 1820]]. Catalog \#150300-12.

4 pp. Piano solo.

Dating: Wolfe II, 516, $\# 5297$.

172) Dearest sweetest bonny lassie! A ballad. With symphonies \& accompaniments for the piano forte. Composed by John Davies. New York: W. Dubois [1820?]. Catalog \#374727.

3 pp. Voice w/piano acc.

Dating: Wolfe I, 232, \#2279.

173) "Oh tell me how from love to fly". Song composed for Miss McCausland by A. Clifton. Baltimore: T. Carr [1820?].

2 pp. Voice w/piano acc. Composed by Arthur Clifton, assumed name of Philip Anthony Corri.

Dating: Wolfe I, 197, \#1942.

174) Absence. The words adapted to the favorite air of Rousseau's dream. Philadelphia:

G.E. Blake [1820-24]. Catalog \#374727.

1 p. Voice w/piano acc.

Dating: Wolfe II, 762, \#7656.

175) Let this brow on thy bosom reclining. A favourite song words by $\mathrm{S}$. H. Jenks music by C.E. Phillips. Boston: G. Graupner [1820-25].

2 pp. Voice w/piano acc. Composed by Cyrus E. Phillips.

Dating: Wolfe II, 688, \#7024.

176) Come rest in this bosom! Written by T. Moore Esqr. Adapted to the favorite air Fleuve du Tage. New York: W. Dubois [1821]. Catalog \#374727.

$2 \mathrm{pp}$. Voice w/harp or piano acc.

Metronome indication of 88 per 8 th note. 
Dating: Wolfe II, 703, \#7163.

177) Hummel's celebrated waltz. With variations for the piano forte. Composed by Gelineck. New York: W. Dubois [1821]. Uncataloged (Music book marked Harriet A. Stanton). $11 \mathrm{pp}$. Piano solo.

At foot of t.p. r.h. cor.: Sold by C. B. De Riemer \& Co. Auburn.

Stamp: E. Riley / 29 Chatham St. / N-Y.

Dating: Wolfe I, 430, \#4396.

178) A captive once said to a linnet. A favourite ballad sung with unbounded applause by Mrs. French. Philadelphia: Geo. Willig [1821?]. Catalog \#151539.

$2 \mathrm{pp}$. Voice w/harp or piano acc.

Dating: Wolfe I, 149, \#1514.

179) [Latour's overture No. 1] New Edition. Overture for the piano forte, in which is introduced a favorite air. Composed by T. Latour. New York: W. Dubois [1821?].

Catalog \#151534.

9 pp. Piano solo.

Stamp: Sold at Willig's music store Balto.

Dating: Wolfe II, 514, \#5285.

180) [Latour's overture No. 2]. New Edition. Overture for the piano forte, in which is introduced a favorite air. Composed by T. Latour. New York: W. Dubois [1821?].

Catalog \#151534.

9 pp. Piano solo.

Dating: Wolfe II, 515, \#5286.

181) The banks of Allan water. A ballad. As sung by Mrs. Holman. The words by M.G. Lewis, Esqr. Arranged for the piano forte by C.E. Horn. New York: Dubois \& Stodart [1821-23]. Uncataloged (Music book marked Harriot A. Stanton).

$2 \mathrm{pp}$. Voice w/piano acc.

Dating: Wolfe I, 421, \#4294.

182) The braes o' Balquhither. A favorite Scotch ballad. With symphonies \& accompaniments for the piano forte. composed by John Davies. New York: Dubois \& Stodart [1821-23]. Catalog \#374727.

$3 \mathrm{pp}$. Voice w/piano acc.

Dating: Wolfe I, 232, \#2278.

183) A favorite waltz. Composed by M.A. Mozart. New York: Dubois \& Stodart [182123]. Catalog \#151514.

2 pp. Voice w/piano acc.

Dating: Wolfe II, 617, \#6336.

184) My love's the fairest creature or Shelah na Conolan. Boston: E.W. Jackson [182123].

2 pp. Voice w/piano acc. Composed by James Hewitt? [see Wolfe I, 378, \#3747].

Dating: Not in Wolfe, Dichter \& Shapiro, 209. 
185) Rest, weary traveller. Duetto, from the comic opera of The devils bridge. Composed by Mr. Braham. Philadelphia: G.E. Blake [1821-24]. Catalog \#151502.

4 pp. Two voices w/piano acc. Composed by John Braham

Dating; Wolfe I, 122, \#1193.

186) Rest, weary traveller. Duetto from the comic opera of The Devils Bridge. By Mr.

Braham. Philadelphia: G.E. Blake [1821-24]. 2nd copy.

4 pp. Two voices w/piano acc. Composed by John Braham.

Dating: Wolfe I, 122, \#1193.

187) I am wearing awa' to the land o' the leal. A Canzonet. Arranged for the Piano Forte by J. Ross. Boston: E.W. Jackson [1821-26].

2 pp. Voice/w piano acc. Arranged by John Ross.

Dating: Wolfe, III, 1141.

Two copies of this music published by S. Wood in Boston have the publisher's name crossed out in ink and the initials "EWJ" [Edwin W. Jackson] inserted above (Wolfe II, 755, \#7587).

188) O swiftly glides the bonny boat, a Scotch air as sung at the anacreontic society, Baltimore, arranged with an accompaniment for the piano forte by Beethoven, the words by Johanna Bailie, with three additional verses by John Pattison Esqr. Baltimore: John Cole [1822].

2 pp. Voice w/piano acc.

At head of title: (Entered according to Act of Congress May 4, 1822.)

Dating: Wolfe I, 46, \#491.

189) Charlie is my darling. A popular Scotch song. Sung with unbounded applause by Mrs. Holman in the opera of Montrose. New York: Dubois \& Stodart [1822?]. Catalog \#374727.

$3 \mathrm{pp}$. Voice $w /$ piano acc.

Dating: Wolfe I, 178, \#1770.

190) Love and Time. As sung by Mrs. Holman. Written by Thomas Moore Esqr.

Composed by Michael Kelly. New York: Dubois \& Stodart [1822?].

2 pp. Voice w/piano acc.

Dating: Wolfe II, 469, \#4810.

191) Oh, what a row! or The adventures of a steam packet. A new comic song as sung by Mr. Barnes. New York: E. Riley [1822?]. Catalog \#374727.

3 pp. Voice w/piano acc.

With engraving of steam packet trailing an American flag on p. 1.

Dating: Wolfe II, 647, \#6602.

192) We're a noddin at our house at home. The popular ballad sung by Mrs. Holman with the greatest applause in the opera of Montrose. New York: Dubois \& Stodart [1822?].

Catalog \#374727.

3 pp. Voice w/piano acc.

Dating: Wolfe I, 349, \#3469. 
193) Oh! Say not woman's love is bought. A favorite ballad. Sung with the most rapturous applause by Miss Stephens. Composed by John Whitaker. Philadelphia: G. Willig [ca 1822]. Catalog \#151551.

$2 \mathrm{pp}$. Voice w/piano acc.

Metronome indication of 50 per quarter note.

Dating: Wolfe III, 959, \#9850.

194) The washing day. As sung at the Theatre and gardens with enormous applause. Arranged for the piano forte by Pietro Norami. Philadelphia: Geo. Willig [182-?].

3 pp. Voice w/piano acc. A reissue of this song published by P.K. Moran in New York, 1822 ? with new imprint at Philadelphia.

Dating: Wolfe, II, 642, \#6542B.

195) Yankee Doodle. Arranged with variations for the piano forte. Philadelphia: G. Willig [1822-23]. Catalog \#151520.

2 pp. Piano solo.

Dating: Wolfe III, 983, \#10078.

196) A highland laddie heard of war. Sung by Mr. Sinclair in the opera The Slave selected from a favorite Scotch melody arranged by Henry R. Bishop. Philadelphia: Geo. Willig [1822-24].

$2 \mathrm{pp}$. Voice w/piano acc.

Dating: Wolfe I, 61, \#632.

Oboe indicated on p. 1.

197) A Catalogue of Music. Published by Dubois \& Stodart. No. 126 Broad Way New York. [1822-26].

5 pp. (missing pp. 3-4.

Dating: Dichter \& Shapiro, 188.

198) Farewell but whenever you welcome the hour written by Thos. Moore, Esqr. The music arranged by Sir John Stevenson, M.D. New York: E. Riley, New York [1822-26]. 3 pp. Voice w/piano acc.

Dating: Wolfe II, 855, \#8723.

Circular stamp reads: "Sold by P.H. Taylor Richmond Va."

199) To ladies eyes, A favorite Irish Melody. Written by Thos. Moore, Esqr. \& Sung with great Applause By Mr. Keene. New York: E. Riley [1822-26].

2 pp. Voice w/piano acc. Composed by John Andrew Stevenson.

Dating: Wolfe II, 879, \#9004.

200) My ain kind dearie. With variations by D. Corri. New York: E. Riley [1822-26]. Uncataloged (Music book signed Harriot A. Stanton).

3 pp. Piano solo.

Dating: Wolfe I, 216, \#2108.

201) The Revolutionary soldier's lullaby. Written by General North. Composed by Storace. New York: E. Riley [1822-26].

2 pp. Voice w/piano acc.

Dating: Wolfe II, 887, \#9114. 
202) Le retour de Kips Hill. Arranged as a rondo for the piano forte. Respectfully dedicated to Miss Maria Coster by William Martin. New York: A. \& W. Geib [1822-27]. Catalog \#374727.

6 pp. Piano solo.

203) Strike the cymbal composed by Pucitta. Baltimore: G. Willig [1822-29].

4 pp. 4 voices w/piano acc. Composed by Vincenzo Pucitta.

Dating: Dichter \& Shapiro, 244.

204) Believe me if all those endearing young charms. Baltimore: G. Willig Jr. [1823]. 1 p. Voice w/piano acc. Composer: John Andrew Stevenson.

At head of title: Melody Sketches No. 1 Copy right secured the fourth day of August 1823.

Dating: Wolfe II, 847, \#8631.

205) I left thee where I found thee love! As sung with rapturous applause by Mrs. Holman at the oratorio given at the Park Theatre. Music composed and dedicated to Mrs. Marion Woodhull by Charles Gilfert. New York: Dubois \& Stodart [1823]. Catalog \#374727. 3 pp. Voice w/piano acc.

Stamp: H. Sage 214 Broadway. Music \& Book-Store.

Dating: Wolfe I, 307, \#3042.

206) The rejected lover. Song by A. Clifton sung by Mrs. Burke. Philadelphia: G. Willig [1823].

2 pp. Voice w/piano acc. Composed by Arthur Clifton, assumed name of Philip Anthony Corri.

At head of title: Entered according to Act of Congress the fourteenth day of April, 1823, by George Willig of the State of Pennsylvania.

Dating: Wolfe I, 198, \#1952.

207) A temple to friendship. A Spanish air. As sung with the greatest applause by Mr.

Keene. From Moores National Melodies. Arranged by Sir John Stevenson, Mus. Doc.

New York: Dubois \& Stodart [1823]. Catalog \#374727.

3 pp. Voice w/piano acc.

In lower margin, p. 1: *The thought is taken from a Song by Le Prieur, called "La Statue de l'Amitie."

Dating: Wolfe II, 877, \#8978.

208) A temple to friendship, A Spanish air, as sung with the greatest applause by $\mathrm{Mr}$.

Keene. From Moores National Melodies. Arranged by Sir John Stevenson, Mus. Doc.

New York: Dubois \& Stodart [1823]. 2nd copy.

$3 \mathrm{pp}$. Voice $\mathrm{w} / \mathrm{piano}$ acc.

Dating: Wolfe II, 877, \#8978.

209) All that's bright must fade. Indian Air, from Moore's National Melodies arranged by Sir John Stevenson, Mus. Doc. Philadelphia: G. Willig [1823?].

$2 \mathrm{pp}$. Voice w/piano acc.

Dating: Wolfe II, 846, \#8614. 
210) My Henry is gone, inscribed to and sung with distinguished approbation by Mrs. Ashe, composed by Sir John Stevenson Mus. Doc. Philadelphia: G. Willig [1823?].

$2 \mathrm{pp}$. Voice w/piano acc.

Dating: Wolfe II, 866, \#8866.

211) The apparition of a dandy. Song. Conposed by A. Clifton. The words by Charles Temple, Esqr. Philadelphia: Geo. Willig [182-?].

2 pp. Voice w/piano acc. Composed by Arthur Clifton, assumed name of Philip Anthony Corri.

Reissue from edition published by the author, Baltimore, 1823.

Dating: Wolfe, I, 192, \#1908A.

212) The bird waltz, for the harp or piano forte. Composed by Francis Panormo.

Philadelphia: J.G. Klemm [1823-24].

3 pp. Piano or harp solo.

Plate no. 116. Reissue of edition by Bacon \& Co., Philadelphia [1819?]

Dating: Wolfe II, 662, \#6772A.

213) Cheer up! pull away. A boat song from Forrest's Travel's. Composed \& dedicated to William B. Finch Esqr., of the United States Navy, by T. V. Wiesenthal. Philadelphia: J. G. Klemm [1823-24].

4 pp. Voice w/piano acc.

At head of music p. 2: American Musical Miscellany No. 2.

Plate No. 106.

Reissue of second state of edition published by Bacon \& Co., Philadelphia [1818?].

Dating: Wolfe III, 963, \#9893B.

214) The gathering of the clans. A favorite Scotch Ballad with symphonies \& accompaniments for the piano forte by A. B. Philadelphia: G. Willig [1823-24]. 2 pp. Voice w/piano acc.

Dating: Wolfe, I, 34, \#382.

215) Hail Columbia! With variations for the flute and an accompaniment for the piano forte composed \& dedicated to Alexy Betzold Esqr. by R. Dressler of Hamburg. Op. 45. Philadelphia: J. G. Klemm [1823-24].

7 pp. Flute solo w/piano acc. [flute part missing]. Composer, Philip Phile, arranger, Rafael Dressler.

Pub no. 134.

Reissued from plates engraved for and used by Bacon \& Co., Philadelphia, in 1819.

Stamp: "Sold at G. Willig's Musical Magazine Philad."

Dating: Wolfe II, 684, \#6988.

216) Home! sweet home! Sung by Miss M. Tree in Clari, or The maid of Milan, at the Theatre Royal, Covent Garden. Composed \& partly founded on a Sicilian air by Henry $R$. Bishop. Philadelphia: George Bacon [1823-24]. Catalog \#374727.

3 pp. Voice w/piano acc.

Dating: Wolfe I, 60, \#637.

217) Le Jeu D'Esprit, a favorite rondo, for the piano forte. Philadelphia: J.G. Klemm [1823-24]. 
3 pp. Piano solo. J.R. Parker's catalog, 1820, designates "Latour" as the composer. Pub. no. 48.

Reissue of the publication by Bacon \& Co. in Philadelphia [1817?].

Dating: Not in Wolfe, based on the earliest reissue of

Bacon's publications by J.G. Klemm.

218) The Lee Rigg with Variations. Baltimore: Geo. Willig [1823-24].

3 pp. Piano solo.

Dating: Wolfe II, 521, \#5341.

219) Look out upon the start my love. A serenade written by a gentleman of Baltimore, and adapted to a favourite air, with an accompaniment for the pianoforte and Spanish guitar, by H. N. Gilles. Baltimore: John Cole [1823-24].

$2 \mathrm{pp}$. Voice w/piano and guitar acc. Composed by Henri-Noel Gilles.

Stamp: "Sold by J.L. Hewitt 137 Broadway N. York" [1832, dating Dichter \& Shapiro, 205].

At head of title: Entered according to Act of Congress the 20th day of January, 1823.

Pub. no. N18.

Dating: Wolfe I, 313, \#3098A.

220) Lullaby. Arranged as a rondo for the piano forte by Steibelt. Philadelphia: J.G.

Klemm [1823-24].

5 pp. Piano solo. Composed by Stephen Storace and arranged by Daniel Steibelt.

Pub. no. 89.

Reissued from Bacon \& Co., Philadelphia [1818?].

Dating: Wolfe II, 887, \#9107A.

221) March \& chorus in the dramatic romance of The Lady of the lake composed by Mr. Sanderson. Philadelphia: J.G. Klemm [1823-24].

1 p. (only the first page is in CSmH). 3-part chorus w/piano acc. Composed by James Sanderson.

Pub. no. 16.

Reissued from publication by A. Bacon \& Co., Philadelphia [1816?].

Dating: Wolfe II, 773, \#7781B.

222) Miss Dennett's waltz. With variations for the piano forte by N.B. Challoner.

Philadelphia: J.G. Klemm [1823-24].

4 pp. Piano solo. Composed by Neville Butler Challoner.

Pub. no. 192.

Reissued from publication by A. Bacon \& Co., Philadelphia [1821?].

Dating: Not in Wolfe, based on the date of the earliest reissues of Bacon's publications by J.G. Klemm.

223) A much admired duett for two performers on one piano forte, in which is introduced the favorite air of $\mathrm{O}$ dolce concento. With variations composed by $T$. Latour. New York:

E. Riley [1823- 24]. Catalog \#151533.

$11 \mathrm{pp}$. Piano four hands.

Dating: Wolfe II, 512, \#5263. 
224) Ne'er can the rose from the comic opera of the Marriage of Figaro arranged with an accompaniment for the harp or piano forte by Henry R. Bishop. Philadelphia: G. Willig [1823-24].

2 pp. Voice /w harp or piano acc. Composed by W. A. Mozart.

Dating: Wolfe I, 69, \#735 listed as unlocated.

225) Of a' the airs. A favorite Scotch ballad written by R. Burns. Philadelphia: G. Willig [1823-24].

2 pp. Voice w/piano acc.

Dating: Wolfe II, 648, \#6628.

226) Overture to the opera of The two blind men of Toledo. Composed by Mehul.

Arranged as a duett for two performers on one piano forte by M. Henkel. Philadelphia:

Geo. Willig [1823-24].

$11 \mathrm{pp}$. Piano four hands. Composed by Etienne Nicolas Mehul, arranged by Michael

Henkel.

Dating: Wolfe, II, 558, \#5752.

227) Prince Kutusoff, a much admired dance arranged as a rondo for the piano forte by

Ed. Parish. Philadelphia: J.G. Klemm [1823-24].

4 pp. Piano solo. Composed by Edward Parish.

Pub. no. 94.

Reissued from the publication by Bacon \& Co., Philadelphia [1818?].

Dating: Wolfe II, 663, \#6784A.

228) Purcell's ground, with variations. A favourite lesson for the piano forte. Philadelphia:

J.G. Klemm [1823-24].

3 pp. Piano solo. Spuriously attributed to Purcell.

Reissued from plates engraved and used by Bacon \& Co., Philadelphia, 1821.

Dating: Wolfe II, 717, \#7267.

229) Russian march, and the emperor Alexanders waltz. Philadelphia: G. Willig [1823-

24].

1 p. [second page is missing]. Piano solo.

Dating: Wolfe II, 767, \#7712.

230) St. Patrick's day, arranged as a rondo for the harp or piano forte by $T$. Cooke.

Philadelphia: J.G. Klemm [1823-24].

5 pp. [pp. 3-4 bound incorrectly]. Harp or piano solo. Composed by Thomas Simpson Cooke.

Cues given for oboe, violin, and flute.

Pub. no. 189.

Reissued from publication by Bacon \& Co., Philadelphia [1821?].

Dating: Wolfe I, 213, \#2079A.

231) Soldier rest, the fight is over. Mrs. Burke's celebrated pollacca composed and dedicated to her (his pupil) by A. Clitton (by permission of the author) (words by Lieut. Hall of the U.S. Army.). Philadelphia: Geo. Willig [1823-24].

$4 \mathrm{pp}$. Voice w/piano acc. Composed by Arthur Clifton, assumed name of Philip Anthony Corri. 
At head of title: Entered according to Act of Congress the twenty-first day of November, 1820 , by Arthur Clifton of the State of Maryland.

Dating: Wolfe I, 199, \#1956.

232) Sul margine dun rio. A favorite Italian air. With 12 variations for the piano forte, with an accompaniment for the flute ad lib. Dedicated to Colonel Bloomfield, by $\mathrm{T}$.

Latour. Philadelphia: G. Willig [1823-24]. Catalog \#151536.

$13 \mathrm{pp}$. Flute solo w/piano acc., flute part, $4 \mathrm{pp}$.

Dating: Wolfe II, 517, \#5304.

233) Tis not his form, so fair to view sung by Miss $M$. Tree, in The Gnome King; also in the Romance of Ivanhoe, or the Knight Templar. Composed by Henry R. Bishop.

Philadelphia: J.G. Klemm [1823-24].

2 pp. Voice w/piano acc.

Pub. no. 204.

Reissued from plates engraved for and used by Bacon \& Co., in 1821.

Dating: Wolfe I, 63, \#668.

234) Look out upon the stars my love. A serenade. Written by a gentleman of Baltimore, and adapted to a favourite air. With an accompaniment for the pianoforte and Spanish guitar by H.N. Gilles. Baltimore: John Cole [1823-24]. Uncataloged (Music book marked Harriet A. Stanton).

$2 \mathrm{pp}$. Voice w/piano and guitar acc.

Pub. no. N18.

On p. 1 above title: Entered according to Act of Congress, the 20th day of January, 1823. Reprint of publication of 1823 probably in 1824.

Dating: Copyright notice; Wolfe I, 313, \#3093A.

235) The New York admired cotillions. New York: Firth \& Hall [1823-31]. Uncataloged (Music book signed Harriot A. Stanton).

3 pp. Piano solo.

Three songs are engraved with directions on the dance steps after each song entitled: La belle favorite; Washington hall, The fleet.

Dating: Dichter \& Shapiro, 192.

236) And canst thou think. Spanish melodies, sung by Mr. Learman written by J. R. Planche Esqr. The Symphonies \& Accompaniments by C. M. Sola Philadelphia: G. Willig [1824].

2 pp. Voice w/piano acc.

Dating: Wolfe I, 14, \#129 (unlocated!).

237) From flowers which we twine for the temples of love. Sung by Mr. Pearman; in Clari, or the Maid of Milan. At the Philadelphia Theatre. The poetry by J.R. Plance Esqr. Composed by Henry R. Bishop. Philadelphia: G. Willig [1824].

2 pp. Voice w/piano acc.

Dating: Wolfe I, 58, \#614.

238) How oft when watching stars, A Savoyard air. The words written by Thomas Moore arranged with an accompaniment for the Piano Forte by Henry R. Bishop. New York:

Dubois \& Stodart [1824]. 
3 pp. Voice w/piano acc.

Dating: Wolfe I, 62, \#655.

239) O swiftly glides the bonny boat. A Scotch air written by Johanna Bailie arranged for the piano forte by J. F. Hance. New York: Dubois \& Stodart [1824].

$3 \mathrm{pp}$. Song and four part chorus w/piano acc. Arranged by James F. Hance.

In lower margin p. 1: Entered according to Act of Congress by Dubois and Stodart, New York, the third day of December 1824.

Dating: Wolfe I, 336, \#3326.

240) Poor old maids. Baltimore: G. Willig [1824].

1 p. Voice w/piano acc.

Dating: Wolfe II, 707, \#7197 (unlocated!).

Also engraved on this sheet is The Black Bird for piano solo.

241) Riego's celebrated quick step. Arranged for the piano forte by A. Clifton. Baltimore: G. Willig [1824].

3 pp. Piano solo, cues for trumpets, tambourine, band, drums, and bugle.

Composed by A. F. Huerta y Katurla, arranged by Arthur Clifton, assumed name of Philip Anthony Corri.

In lower margin, p. 1: Entered according to Act of Congress the twenty-seventh day of December, 1824 by G. Willig of the state of Maryland.

Dating: Wolfe I, 429, \#4386.

242) Silent glances. Sung by Mrs. Holman, composed with an accompaniment for the piano forte by John Davies. New York: E. Riley [1824].

$3 \mathrm{pp}$. Voice w/piano acc.

In lower margin p. 1: Copy right secured according to Law, February 4th 1824 James Dill, Clerk.

Dating: Wolfe I, 232, \#2283[A], this music represents a second state of \#2283 because it leaves out the words "\& inscribed to his friend, Wm. Taylor, Esq."

243) Washington's favourite the brave La Fayette. Written by a gentleman of this city to a favourite air. Arranged with a chorus in three parts and an accompaniment for the piano forte. Baltimore: John Cole [1824]. Catalog \#151561.

2 pp. Voice w/piano acc.

In lower margin: Entered, according to Act of Congress, the 21st Aug. 1824 P. Moore Clk. Dis. of Md.

Pl. no. 97.

Dating: Copyright notice; Wolfe II, 822, \#8357B.

244) The Carrier Pigeon, MS. [ca. 1824].

2 pp. Voice w/piano acc. Composed by Peter K. Moran.

Bound with \#3 The Beautiful Maid by John Braham.

This MS. was probably copied from the reissue of Moran's publication by Dubois \&

Stodart.

Dating: Wolfe II, 593, \#6087B.

245) Maid of Athens. Written by Lord Byron. The music by G. Kiallmark. New York: E.

Riley [ca. 1824]. Uncataloged (Music book signed Harriot A. Stanton). 
2 pp. Voice w/piano acc.

Dating: Wolfe II, 482, \#4959.

246) And canst thou think. A Spanish melody. Sung by Mr. Pearman. Arranged by C.M.

Sola. Philadelphia: G.E. Blake [1824?]. Catalog \#374727.

1 p. Voice $w /$ piano acc.

Compare unlocated edition published by G. Willig in 1824 (Wolfe I, 14, \#129).

Not listed by Wolfe.

247) The champion of freedom. Written by Miss Eliza L. Hening. Arranged for the piano forte by C. Meineke. The air by D. Judah Esqr of Richmond. Baltimore: John Cole

[1824?]. Catalog \#151543.

3 pp. Voice w/piano acc.

Dating: Wolfe II, 459, \#4699A.

248) Emperor Alexander's Waltz. New York: E. Riley [1824?].

$1 \mathrm{p}$. Piano solo. Bound as the back of $\mathrm{O}$ swiftly guides the bonny boat.

Dating: Wolfe I, 267, \#2682.

249) Grand march for the piano forte. Composed and respectfully dedicated to Miss $C$.

Boller by John G. Klemm. Philadelphia: J.G. Klemm [1824?].

2 pp. Piano solo, "corno" cue.

Pub. no. 220.

Dating: Wolfe II, 492, \#5079.

250) Haydn's andante, The surprise. Arranged for the piano forte by G. E. Fiorini. Boston: J.L. Hewitt \& Co. [1824?].

2 pp. Piano solo.

Dating: Wolfe I, 352, \#3487.

251) Isabel. A celebrated Spanish serenade. Sung by Miss Stephens at the Nobilities Concerts. Written by Thomas Bayly, Esq. The symphonies and accompaniments by Henry R. Bishop. Baltimore: John Cole. [1824?]. Catalog \#151552.

$2 \mathrm{pp}$. Voice w/piano acc.

Dating: Wolfe I, 63, \#664.

252) I won't be a nun [Philadelphia: J. Klemm?, 1824?].

$1 \mathrm{p}$. Voice w/piano acc.

Page no. 4, 1.h. cor.

Pub. no. 216

Dating: Based on pub. no., Wolfe, III, 1198.

253) Mad. de Nouville's waltz. Philadelphia: J.G. Klemm [1824?].

1 p. Piano solo.

Pub. no. 215.

Dating: Wolfe II, 536, \#5495.

254) Mrs. Poe. Baltimore: G. Willig [1824?].

1 p. voice w/piano acc.

At head of page: Expressly arranged for Willig's Musical Miscellany No. 7.-Copy right. 
Dating: Wolfe II, 574, \#5876.

255) My heart's in the highlands. Philadelphia: J.G. Klemm [1824?].

1 p. Voice w/piano acc.

Dating: Wolfe II, 627, \#6398A.

256) Oh 'tis love sung by Mr. Pearman in I will have a wife, at the New York Park Theatre, Adapted to the French Air c'est l'amour written by I.R. Plance By G.W. Reeve. New York: E. Riley [1824?].

2 pp. Voice w/piano acc. Composed by George William Reeve.

Dating: Wolfe, II, 721, \#7313.

257) Oh 'tis love sung by Mr. Pearman in I will have a wife, at the New York Park Theatre, Adapted to the French Air c'est l'amour written by I.R. Plance By G.W. Reeve. New York: E. Riley [1824?]. 2nd copy.

$2 \mathrm{pp}$. Voice w/piano acc. Composed by George William Reeve.

Dating: Wolfe, II, 721, \#7313.

258) Oh 'tis love [Adapted from the French air, C'est l'amour by G. W. Reeve. Written by J.R. Planche.] n.p., [Philadelphia: J. Klemm?, 1824?]

1 p. Voice w/piano acc. Composed by George W. Reeve.

Page number 3, r.h. cor.

Pub. no. 216.

Dating: Based on pub. no., Wolfe, III, 1198.

Reverse side is "I won't be a nun."

259) The pirate lover. Sung by Mrs. French. The poetry by I.G. Percival. The music composed by J. Aykroyd. Philadelphia: G.E. Blake [1824?]. Catalog \#151536.

$2 \mathrm{pp}$. Voice w/piano acc.

In lower margin p. 1: No. 69, Blake's Musical Miscellany.

Dating: Wolfe I, 33-4, \#377.

260) The plain gold ring the words by W. T. Moncrieff Esq. adapted to an air in Der Freyshutz by C.M. von Weber. Baltimore: G. Willig [1824?].

$3 \mathrm{pp}$. Voice w/piano acc.

Dating: Wolfe III, 945, \#9706.

261) Saw ye my wee love. An admired Scotch ballad by Hector McNiel Esq. as sung with unbounded applause by Mr. Pearman arranged with symphonies \& accompaniments for the Piano Forte by Alex. Robertson. Philadelphia: G. Willig [1824?].

3 pp. Voice w/piano acc. Composed by Alexander Robertson.

Dating: Wolfe II, 747, \#7507.

262) Slowly wears the day, love. Sung with the greatest applause by Mr. Pearman. Words by J. R. Planche, Esq. Composed with an accompaniment for the harp or piano forte by N. C. Bochsa. Baltimore: G. Willig [1824?].

2 pp. Voice w/piano acc. Composed by Robert Nicholas Charles Bochsa.

Dating: Wolfe I, 94, \#915. 
263) Stantz waltz. With variations for the harp or piano forte. By P.K. Moran. New York: E. Riley [1824?]. Uncataloged (Music book marked Harriet A. Stanton).

6 pp. Piano solo.

Following music on p. 6: Piano fortes tun'd and repair'd; and a list of 34 songs published by E. Riley (listed in Wolfe II, 598).

Dating: Wolfe II, 598, \#6125A.

264) Waters of Elle extracted from Glenaroon arranged to the air of Ils ne sont plus.

Philadelphia: J.G. Klemm [1824?].

2 pp. Voice $w /$ piano acc.

Pub. no. 202.

Dating: Wolfe $941, \# 9640$.

265) Home! Sweet Home! Philadelphia: G.E. Blake [ca 1824]. Catalog \#151554.

1 p. Voice w/piano acc.

Small notes are provided for a second voice part.

Dating: Wolfe I, 61, \#647.

266) The heart of a woman. The celebrated ballad sung by Mr. Pearman in the new opera of Woman's will A Riddle composed by John Davy. Boston: G. Graupner [1824-25].

2 pp. Voice w/piano acc.

Dating: Wolfe I, 234, \#2302.

267) Let us haste to Kelvin grove. As sung with unbounded applause by Mr. Horn in the opera of Guy Mannering. Written by John Sim Esqr. Arranged by R.A. Smith.

Philadelphia: Geo. Willig [1824-25].

$2 \mathrm{pp}$. Voice w/piano acc.

Dating: Wolfe II, 825, \#8383.

268) Let us haste to Kelvin grove. Sung by Mr. Braham in the opera of Guy Mannering written by John Sim Esq. arranged by R.A. Smith. Philadelphia: G. Willig [1824-25]. 2nd copy.

2 pp. Voice w/piano acc. Arranged by Robert Archibald Smith.

Dating: Wolfe II, $825, \# 8383$.

269) Awake the note of war, recitative \& bravura sung by Mrs. Burke, in the opera of the enterprise written by Col. W. H. Hamilton, composed by A. Clifton. Philadelphia: Geo. Willig [1824-26].

$6 \mathrm{pp}$. Voice w/piano acc. Composed by Arthur Clifton, assumed name of Philip Anthony Corri.

This work was reissued from the composer's publication of 1823 in Baltimore, the imprint altered to read Willig as the publisher.

Dating: Wolfe I, 193, \#1910B.

270) Araby's daughter. From Lalla Rookh. Written by Thomas Moore, Esqr. Composed by G. Kiallmark. Philadelphia: G. Willig [1824-27].

3 pp. Voice w/piano acc.

Dating: Wolfe II, 481, \#4945A. 
271) My heart and lute. A ballad. Written \& arranged by Thomas Moore, Esq. Philadelphia: G. Willig [1824-27].

$2 \mathrm{pp}$. Voice w/piano acc.

Dating: Wolfe II, 595, \#5994.

272) Sicilian air on which is founded the popular ballad of Home! sweet home. Arranged with variations for the piano forte and dedicated to Miss Ellis by Thos. Valentine.

Philadelphia: George Willig [1824-27].

5 pp. Piano solo. Composed by Henry R. Bishop, arranged by Thomas Valentine.

Dating: Wolfe, I, 61, \#650.

273) Do I do I don't do nothing. Negro song. Arranged by an amateur. Baltimore: G. Willig [1825]. Catalog \#151521.

$1 \mathrm{p}$. Voice w/piano acc.

In lower margin: Entered according to act of Congress the 15th day of November 1825 by $\mathrm{G}$ Willig of the state of Maryland.

Dating: Wolfe I, 10, \#98.

274) Follow, follow thro' the sea. The mermaid song. Sung by Miss Kelly. Composed by Martini. Adapted \& arranged by Henry R. Bishop. New York: Dubois \& Stodart [1825]. $5 \mathrm{pp}$. Voice w/piano acc. Composed by Vincente Martin y Soler.

Clar.[inet] part written in a five measure cadenza with soprano voice at the end of the work.

Dating: Wolfe II, 545, \#5601.

275) Go my love. A Rondo sung by Miss Kelly composed by H. R. Bishop. New York: Dubois \& Stodart [1825].

5 pp. Voice w/piano acc. Composed by Henry R. Bishop.

Dating: Wolfe I, 59, \#619.

Flute solo and Tutti indicated on page 1.

276) The Grand Canal Celebration, Ball. Composed by R.L. Williams. New York: E. Riley [1825]. Catalog \#151517.

3 pp. Piano solo.

Below publishing statement: Copy right secured according to Law, Novr. 11th 1825, James Dill, Clerk S. District, of N.Y.

In lower margin p. 1: * Each strain throughout this Piece may be repeated an Octave higher.

277) I'll pull a bunch of buds and flowers by John Cole. MS [1825]. Catalog \#150300-12 $2 \mathrm{pp}$. Voice/w piano acc.

A manuscript copy of the song published by John Cole.

Dating: Wolfe I, \#1979.

278) Oh Lady ne'er think I'll prove false to thee. A favourite song as sung by Mr. Keene. Composed by John Sinclair. New York: Dubois \& Stodart [1825]. Catalog \#374727. 3 pp. Voice w/piano acc.

Dating: Wolfe II, 814, \#8267. 
279) Say my heart why wildly beating. A favorite song in the popular melod drama of Der Freischutz or The seventh bullet. Composed by C.M. von Weber. New York: Dubois \& Stodart [1825].

$3 \mathrm{pp}$. Voice w/piano acc. Composed by Carl Maria von Weber.

Dating: Wolfe III, 946, \#9716.

280) Titus March. By a Lady of Baltimore. Baltimore: G. Willig [1825].

1 p. Piano solo.

Dating: Wolfe, II, 505, \#5197.

281) They're a' noddin. A favourite Scotch song sung by Mrs. French. Arranged by John Parry. Philadelphia: John G. Klemm [1825].

2 pp. Voice w/piano or harp.

Pub. no. 252.

Dating: Wolfe, II, 668, \#6833.

282) Tyrant! soon I'll burst thy chains. An air by Rossini. Sung at the Philharmonic Concert by Miss L. Gillingham. Adapted to English words by Henry R. Bishop. New York: Dubois \& Stodart [1825].

7 pp. Voice w/piano acc. Composed by Gioacchino Antonio Rossini.

Dating: Wolfe II, 761, \#7646.

283) The bridesmaids song \& chorus in the melo drame of Der Freischutz. Composed by C.M. von Weber. Philadelphia: J.G. Klemm [1825?].

$2 \mathrm{pp}$. Voice w/piano acc.

Pub. no. 230.

Dating: Wolfe III, 944, \#9685.

284) Burlington arcade, A favorite air in Tom and Jerry. n.p. [Philadelphia: J.G. Klemm, 1825?].

1 p. Voice w/piano acc.

Pub: no: 254.

Dating: The printing fonts and pub. numbers are identical to those use by Klemm (unlocated in Wolfe, III, 1199).

285) The celebrated hanseatic quickstep march. Arranged for the piano forte. Philadelphia: John G. Klemm [1825?].

2 pp. Piano solo.

Pub. no. 256.

Dating: Wolfe I, 342, \#3387.

286) Cherry ripe. A favourite song. Sung by Mrs. Burke. Composed \& arranged with an accompaniment for the piano forte by C.E. Horn. Philadelphia: John G. Klemm [1825?]. 3 pp. Voice w/piano acc. Composed by Charles E. Horn.

Pub. no. 257.

Dating: Wolfe, I, 422, \#4303.

287) Far, far o'er hill and dell. A Spanish melody. Philadelphia: J.G. Klemm [1825?].

2 pp. Voice w/piano acc. Composed by Charles Michel Alexis Sola.

Pub. no. 223. 
Dating: Wolfe, II, 827, \#8411.

288) The favourite Bath waltz. New edition. n.p. [1825?].

1 p. Piano solo.

Dating: The title is identical to that published by John Cole in Baltimore [1825?]; see Wolfe I, 43, \#456.

289) Hours there were. A favourite song. Written and arranged for the piano forte by Joseph A. Wade Esqr. Philadelphia: John G. Klemm [1825?].

2 pp. voice $w /$ piano acc.

Pub. no. 253.

Dating: Wolfe III, 933, \#9544A.

290) I'll watch for thee from my lonely bow'r. Ballad. Adapted to a German air. The symphonies \& accompaniments by Sir J. A. Stevenson. Baltimore: John Cole [1825?]. 3 pp. Voice w/piano acc. Composed by Wolfgang Amadeus Mozart, arranged by John Andrew Stevenson.

Pub. no. 143.

Dating: Wolfe II, 608, \#6245.

291) Let us haste to Kelvin grove. Sung by Mr. Braham in the opera of Guy Mannering. Written by John Sim, Esqr. Arranged by R.A. Smith. Philadelphia: John G. Klemm [1825?].

2 pp. voice w/piano acc. Arranged by Richard Archibald Smith.

Pub. no. 258. This work is identical to the publication by Willig and was probably copied from it.

Dating: Wolfe II, 825, \#8384.

292) March in the melodrama of Der Freyschutz. Composed by Weber. Philadelphia: J.G. Klemm [1825?].

1 p. Piano solo.

Pub. no. 229.

Dating: Wolfe, III, 945, \#9697.

293) The midshipman. Philadelphia: J.G. Klemm [1825?].

$1 \mathrm{p}$. Voice w/piano acc. Composed by William Shield.

Pub. no. 248.

Dating: Wolfe II, 803, \#8107.

294) Moravian waltz. Composed \& arranged for the piano forte by J. L. Dussek.

Philadelphia: J.G. Klemm [1825?].

2 pp. Piano solo. Composed by Jan Ladislav Dussek.

Pub. no. 246.

Dating: Wolfe I, 259, \#2622.

295) My heart and lute. Ballad. Written \& arranged by Thomas Moore. Philadelphia: J. G. Klemm [1825?].

2 pp. Voice $w /$ piano acc.

Pub. no. 228.

Dating: Wolfe, II, 585, \#5996. 
296) Run Jerry Run. Sung in Tom and Jerry. n.p. [Philadelphia: J.G. Klemm, 1825?]. 1 p. Voice $w /$ piano acc.

Pub. no. 255.

Dating: the fonts and pub. number are similar to those used by Klemm, unlocated by Wolfe.

297) Tho 'tis all but a dream. A French air from Moores National Melodies. Arranged by Henry R. Bishop. Philadelphia: John G. Klemm [1825?].

2 pp. Voice w/piano acc.

Pub. no. 250.

Dating: Wolfe I, 77, \#824.

298) United States Marine March. Composed and dedicated to the officers of the Marine Corps. by a Lady of Charleston, S.C. Baltimore: John Cole [1825?].

2 pp. Piano solo.

Pub. no. 108.

Dating: Wolfe, II, 619, \#6362.

299) Where is my lover? Sung by Miss Stephens with the most unbounded applause. Words by T. Bailey, Esqr. Arranged for the piano forte by Edwd. Knight, Jr. Baltimore: John Cole [1825?].

$2 \mathrm{pp}$. Voice $\mathrm{w} / \mathrm{piano}$ acc.

Pub. no. 116.

Dating: Wolfe II, 494, \#5089.

300) The dashing white sergeant. A favourite song. Composed by Henry R. Bishop. Philadelphia: G.E. Blake [ca 1825]. Catalog \#151557.

2 pp. Voice w/piano acc.

Dating: Wolfe I, 56, \#597.

301) Hummel's celebrated waltz. With variations for the piano forte. Composed by Gelineck. Baltimore: G. Willig [ca 1825].

11 pp. Piano solo. Composed by Johann Nepomuk Hummel, arranged by Joseph Gelinek. Dating: Wolfe I, 431, \#4393.

302) Love thee dearest. Words by Moore. Music by Viotti, Baltimore: G. Willig [ca 1825].

1 p. Voice w/piano acc. Composed by Giovanni Battista Viotti.

Dating: Wolfe II, 928, \#9305.

303) The Braes o' Balquhiter. Baltimore: G. Willig [1825-29].

1 p. Voice w/piano acc.

Dating: Dichter \& Shapiro, 244.

304) The comet with variations for the piano forte by Gelinek. Baltimore: G. Willig [1825-29].

7 pp. Piano solo. Composed by Joseph Gelinek.

Dating: Dichter \& Shapiro, 244. 
305) Grand Austerlitz march. Arranged for the piano forte by T.F. Hance. Boston: James L. Hewitt [1825-29]. Uncataloged (Music book signed Harriot A. Stanton).

2 pp. Piano solo.

At foot of page: CORRECTED EDITION.

Hewitt's address is printed as No. 70 Market St.

Dating: Dichter \& Shapiro, 205.

306) Araby's daughter. Arranged for the Spanish guitar by B. F. Peale. Philadelphia: G. E. Blake [1826].

1 p. voice w/guitar acc.

Marked No. 51 . lower cor.

At the bottom of the page: Entered according to act of Congress the 29 day of July 1826

by G.E. Blake of the state of Pennsylvania.

Probably from Blake's Musical Miscellany in occasional numbers, no. 48, entitled "Select beauties for the Spanish guitar or lyre."

Dating: Wolfe II, 87-88.

307) Hey the bonnie breast-knots. As sung by Miss George. Arranged for the guitar by B.

F. Peale. Philadelphia: G. E. Blake [1826].

1 p. voice w/guitar acc.

Marked $61 \mathrm{r}$. upper cor. and No. 51 . lower cor.

At bottom of page: Entered according to act of Congress the 29 day of July 1826, by G.

E. Blake of the State of Pennsylvania.

Probably from Blake's Musical Miscellany in occasional numbers, no. 48, entitled "Select beauties for the Spanish guitar or lyre."

Dating: Wolfe II, 87-88.

308) Home arranged for the Spanish guitar by B.F. Peale. Philadelphia: G.E. Blake [1826].

$1 \mathrm{p}$. Voice w/guitar acc.

In lower margin: Entered according to act of Congress the 29th day of July 1826 , by G.E. Blake of the State of Pennsylvania. No. 4.

Dating: copyright notice.

309) Hurrah for the bonnets of blue. As sung by Miss Clara Fisher. Arranged for the guitar by B.E. Peale. Philadelphia: G.E. Blake [1826].

1 p. voice w/guitar.

At bottom of page: Entered according to act of Congress the 29th day of July 1826 by

G.E. Blake of the State of Pennsylvania.

Marked 60 upper 1 . hand cor.

Probably from Blake's Musical Miscellany in occasional numbers, no. 48, entitled "Select beauties for the Spanish guitar or lyre."

Dating: Wolfe II, 87-88.

310) Life let us cherish. Composed by Mozart. Philadelphia: John G. Klemm [1826].

1 p. voice w/piano acc.

Pub. no. 266.

Dating: Wolfe, III, 1196 (by plate number). 
311) Smile again my bonnie lassie. A ballad sung by Miss Kelly. Composed by John Parry. Philadelphia: John G. Klemm [1826].

2 pp. Voice w/piano acc.

Pub. no. 265.

Dating: Wolfe, III, 1196 (by plate number).

312) Theres a tear that flows when we part. A celebrated song composed expressly for Mrs. Burke by $R$. Willis and sung by her with distinguished applause at his Concert. Arranged for the piano forte by W. H. W. Darley. Philadelphia: G. Willig [1826]. $2 \mathrm{pp}$. Voice w/piano acc. Composed by Richard Willis. At head of page one: Entered according to Act of Congress the twenty seventh day of April 1826, by George Willig of the State of Pennsylvania.

Dating: by copyright notice.

313) Bounding billows. A favourite song written by Mrs. Robinson. n.p. [Philadelphia:

J.G. Klemm, 1826?].

1 p. Voice w/piano acc.

Pub. no. 262.

Dating: Krummel, 234 (based on Klemm's pub. no.).

314) Cadets March for the Pianoforte \& Flute. Composed for \& dedicated to the classical \& military Lyceum Mount Airy, German town by E.R. Hansen. Philadelphia: John G. Klemm [1826?].

$2 \mathrm{pp}$. Flute w/piano acc.

Pub. no. 283.

Dating: Wolfe III, 1198 (based on pl. number).

315) Come rest in this bosom. Written by Thomas Moore adapted to the favorite French air Fleuve du Tage. Philadelphia: John G. Klemm [1826?].

2 pp. Voice w/piano acc.

Pub. no. 263.

Dating: Krummel, 234 (based on Klemm's pub. no.).

316) Dearest, sweetest bonnie lassie. Scotch air. Philadelphia: John G. Klemm [1826?].

1 p. Voice w/piano acc.

Pub. no. 274.

Dating: Krummel, 234 (based on Klemm's pub. no.).

317) Divertisement for the piano forte. With an accompaniment for the flute ad lib. on two airs of Rossini's. Composed and dedicated to Miss McMahon by T. Latour. New York: Dubois \& Stodart. [1826?]. Catalog \#151532.

$10 \mathrm{pp}$. (piano part only). One cue for flute, p. 1 . Composed by Jean Tatton Latour. Dating: Dichter \& Shapiro, 188 , not listed in Wolfe.

318) Follow follow thro' the Sea. The celebrated mermaid song sung by Miss Kelly. Composed by Martini. Adapted \& arranged by Henry R. Bishop. Philadelphia: John G. Klemm [1826?].

5 pp. Voice w/piano acc.

Clar.[inet] part is provided with the vocal cadenza. 
Pub. no. 264. Identical to the edition by Dubois \& Stodart [1825] and probably copied from it.

Dating: Krummel, 234 (based on Klemm's pub. no.).

319) I'll watch for thee from my lonely bow'r. Ballad adapted to a German air. The symphonies \& accompaniments by Sir J.A. Stevenson. Philadelphia: John G. Klemm [1826?].

3 pp. Voice w/piano acc. Composed by Wolfgang Amadeus Mozart and arranged by John Andrew Stevenson.

Pub. no. 280. Identical to the publication by John Cole, Baltimore (1825?] and probably copied from it.

Dating: Krummel, 234 (based on Klemm's pub. no).

320) The minstrel's return'd from the war. As sung by Mr. C.W. Taylor. Written \& Composed by I.H.H. Philadelphia: Geo. Willig [1826?].

$2 \mathrm{pp}$. Voice w/piano acc. Composed by John Hill Hewitt.

Dating: based on identification of this work as being composed in 1825. See John Tasker Howard in "The Hewitt family in American music," Musical Quarterly 17 (Jan. 1931): 34.

321) Parisian rondo for the piano forte. Composed by D. Steibelt. Philadelphia: John G. Klemm [ca. 1826].

2 pp. Piano solo. Composed by Daniel Steibelt.

Pub. no. 279.

Dating: Wolfe III, 1196 (by plate number).

322) Le petit tambour. An admired French air partly taken from Mayseder's violin solo. Adapted \& arranged as a rondo for the flute with a piano forte accompaniment by Bernard Lee. New York: Firth \& Hall [ca. 1826].

$13 \mathrm{pp}$. Flute w/piano acc. Composed by Mayseder.

Stamp: Sold by G. Willig 171 Chesnut Phila

Dating: Dichter \& Shapiro, 192.

323) The Origin of the harp. Canzonett. The words by Moore. Arranged either as a solo or duett, with an accompanyment for the harp or piano forte. Philadelphia: Printed for B. Carr, G. Willig proprietor [1826-27]. Catalog \#151547.

$4 \mathrm{pp}$. Voice w/harp or piano acc.

Above title: No. 9 of LYRICKS, or Adaptions, Arrangements and Compositions in Vocal Music by B. Carr and others. To be completed in 36 Numbers. Copy right secured. Dating: Wolfe II, 532-3, \#5475, based on date of first five numbers of this collection.

324) The Jager Chorus from Weber's celebrated opera Der Freischutz. Arranged with variations for two performers on the piano forte by Ge. Fred. Harris. Boston: James L. Hewitt \& Co. [1826-29].

$15 \mathrm{pp}$. Piano four hands.

Dating: Dichter \& Shapiro, 205.

325) All's well. The favorite duett. As sung by M. Braham \& Mr. Incledon. New York: E. Riley [1826-31]. Uncataloged (Music book signed Harriot A. Stanton).

4 pp. Two voices w/piano acc.

Dating: Dichter \& Shapiro, 226. 
326) Away away to the mountains brow. A cavatina as sung with unbounded applause by Miss Hughes, at the Park Theatre. Composed by Alexander Lee. New York: E. Riley [1826-31]. Uncataloged (Music book marked Harriet A. Stanton).

$5 \mathrm{pp}$. Voice w/piano acc.

Dating: Dichter \& Shapiro, 226, composer not in Wolfe.

327) Battle of Waterloo. Composed and dedicated to the Duke of Wellington. Arranged by G. Anderson. New York: E. Riley [1826-31].

5 pp. Piano solo and 4-part chorus w/piano acc.

Dating; Dichter \& Shapiro, 226.

328) The bonnie bark. A Northumbrian ballad. Adapted \& arranged by John Parry. New York: E. Riley [1826-31].

$3 \mathrm{pp}$. Voice w/harp or piano.

Dating: Dichter \& Shapiro, 226.

329) The carnival of Venice. A popular air. Arranged for one or two performers on the piano forte. New York: E. Riley [1826-31]. Uncataloged (Music book marked Harriet A Stanton).

3 pp. Piano four hands.

Dating: Dichter \& Shapiro, 226, not in Wolfe.

330) The celebrated overture to La Dame Blanche. Composed by A. Boieldieu. New York: E. Riley [1826-31]. Uncataloged (Music book marked Harriet A. Stanton). 10 pp. Piano solo.

Stamp: Sold by J.L. Hewitt 137 Broadway New York.

Dating: Dichter \& Shapiro, 226, not in Wolfe.

331) A collection of popular airs arranged as cotillions for balls and private parties, with new figures. New York: E. Riley [1826-31].

2 pp. Piano solo.

Contents include: O nothing in life; Over the hills and far away; The bonnie boat; Oscar and Malvina; My heart and lute; and Dearest lassie.

Instructions for dance steps follow each of these pieces.

Dating: Dichter \& Shapiro,

332) A collection of popular airs. Arranged as cotillions for balls and private parties with new figures. New York: E. Riley [1826-31]. 2nd copy.

2 pp. Piano solo.

Dating: Dichter \& Shapiro, 226.

333) A collection of popular airs. Arranged as cotillions for balls and private parties with new figures. New York: E. Riley [1826-31]. Uncataloged (Music book marked Harriet A. Stanton). 3rd copy.

2 pp. Piano solo, marked [pp] 16-17.

The six works are entitled: The invincibles; The Irish washerwoman, Bonnets of blue; St.

Patrick's day; Bonnie breast knot; and March, march, etrick \&c.

Indications for dance steps are given after each work.

In upper 1.h. cor.: 8th sett cots. 
Dating: Dichter \& Shapiro, 226.

334) The corsair's farewell, song. Written \& composed by Geo. Linley, Esq. New York: E. Riley [1826-31]. Uncataloged (music book marked Harriet A. Stanton).

3 pp. Voice w/piano acc.

Stamp: Sold by J.L. Hewitt / 137 Broadway / New York.

Dating: Dichter \& Shapiro, 226; composer not in Wolfe.

335) The dark eyed one. As sung by Mr. Horn, in the Magic Flute. Composed by Auber. Arranged for the Spanish guitar by S. Keene. New York: E. Riley [1826-31].

2 pp. Voice w/guitar acc.

Dating: Dichter \& Shapiro, 226.

336) Di tanti palpiti. A popular air. Arranged for one or two performers on the piano forte. New York: E. Riley [1826-31]. Uncataloged (Music book signed Harriot A. Stanton).

3 pp. Piano four hands.

Dating: Dichter \& Shapiro, 226.

337) Ellen of Lismore. An Irish melody. The poetry by Barry Cornwall. The symphony and accompaniment by T.Philipps. New York: E. Riley [1826-31].

7 pp. (p. 2 blank). Voice w/piano acc.

Lithograph "of Endicott \& Swett." A woman and child.

Dating; Dichter \& Shapiro, 226.

338) Even as the sun with purple colour'd face. A favorite song sung by Miss Kelly, in Shakespear's revived play of the merry Wives of Windsor. Performed at the Park Theatre. Composed by Charles E. Horn. New York: E. Riley [1826-31].

$6 \mathrm{pp}$. Voice w/piano acc.

Cues in the cadenza pp. 5-6 are for Clar:, Corni, Clarinetto, bugle.

Dating: Dichter \& Shapiro, 226.

339) The favorite pastoral in the coronation of Henry the 5 th. Composed by Steibelt. New York: E. Riley [1826-31]. Uncataloged (Music book signed Harriot A. Stanton).

1 p. Piano solo. Composed by Daniel Steibelt.

Dating: Dichter \& Shapiro, 226.

340) Favorite pieces from the opera Der Freischutz. Composed by von Weber. New York: E. Riley [1826-31]. Uncataloged (Music book signed Harriot A. Stanton).

1 p. Piano solo.

Dating: Dichter \& Shapiro, 226.

341) A favorite Swiss waltz. With variations for the harp or piano forte. P.K. Moran. New York: E. Riley [1826-31]. Uncataloged (Music book signed Harriot A. Stanton).

5 pp. piano solo.

Dating: Dichter \& Shapiro, 226.

342) Herr Cline's dance. New York: E. Riley [1826-31]. Uncataloged (Music book marked Harriet A. Stanton).

1 p. Piano solo. 
Includes two works entitled "Spanish dance."

At foot of page: Sold by C.B. De Riemer \& Co., Auburn.

Dating: Dichter \& Shapiro, 226, not in Wolfe.

343) The hunting chorus. New York: E. Riley [1826-31]. Uncataloged (Music book signed Harriot A. Stanton).

1 p. Piano solo.

Dating: Dichter \& Shapiro.

344) I saw from the beach. From Moore's Irish melodies. Arranged with symphonies and accompaniment by Sir John Stevenson. New York: E. Riley [1826-31].

$3 \mathrm{pp}$. Voice w/piano acc.

Pub. no. 1122.

Dating: Dichter \& Shapiro, 226.

345) The last link is broken. A favorite Duet. Composed \& arranged by William Clifton. New York: E. Riley [1826-31]. Uncataloged (Music book marked Harriet A. Stanton).

3 pp. Duet (2 voices) w/piano acc.

Yellow paper.

Dating: Dichter \& Shapiro, 226; composer not in Wolfe.

346) The light bark. Written by Miss Mahony. Composed by J.T. Craven. New York: E. Riley [1826-31]. Uncataloged (Music book marked Harriet A. Stanton).

3 pp. Voice w/piano acc.

Dating: Dichter \& Shapiro, 226, composer not in Wolfe.

347) Listen dear Fanny. A favorite air. Arranged for the Spanish guitar by S. Keene. New York: E. Riley [1826-31].

$3 \mathrm{pp}$. Voice w/guitar acc.

Stamped: Sold at G. Willig's.

Dating: Dichter \& Shapiro, 226.

348) Money musk. New York: E. Riley [1826-31]. Uncataloged (Music book signed Harriot A. Stanton).

1 p. Piano solo.

Lower half of page: A Scotch reel.

Dating: Dichter \& Shapiro, 226.

349) Le petit tambour. Arranged as a duet for two performers on the piano forte by $M$. Holst. New York: E. Riley [1826-31]. Uncataloged (Music book signed Harriot A.

Stanton).

7 pp. (missing pp. 3-6). Piano four hands.

Dating: Dichter \& Shapiro, 226.

350) Polish march. New York: E. Riley [1826-31]. Uncataioged (Music book signed Harriot A. Stanton).

1 p. Piano solo.

Green paper.

Dating: Dichter \& Shapiro, 226. 
351) Quatre petits morceaus, brillants pour le piano. No. 2 Marche de Moise Doigtes a la portee des petites mains. Par Henry Lemoine. New York: E. Riley [1826-31].

5 pp. Piano solo.

Dating: Dichter \& Shapiro, 226.

352) The soldiers bride. Ballad for the piano forte. New York: E. Riley [1826-31].

2 pp. Voice w/piano acc.

Dating: Dichter \& Shapiro, 226.

353) The soldier's tear. Sung in the opera of Music \& Prejudice. The words by Thos. $H$. Bayly. The music by Alexander Lee. New York: E. Riley [1826-31]. Uncataloged (Music book marked Harriet A. Stanton).

$3 \mathrm{pp}$. Voice w/piano acc.

Cue for trombo p. 1.

Dating: Dichter \& Shapiro, 226, composer not in Wolfe.

354) The sprig of Shillelah. A dance. New York: E. Riley [1826-31]. Uncataloged (Music book signed Harriot A. Stanton).

1 p. Piano solo.

Lower half of page: The New Tekeli.

Dating: Dichter \& Shapire, 226.

355) The stop waltz. New York: E. Riley [1826-31]. Uncataloged (Music book marked Harriet A. Stanton).

1 p. Piano solo.

Dating: Dichter \& Shapiro, 226, not in Wolfe.

356) Three duettos. For juvenile performers on the piano forte. Arranged by J. Gildon. New York: E. Riley [1826-31]. Uncataloged (Music book marked Harriot A. Stanton). 7 pp. Piano four hands.

Missing pp. 3-6.

Dating: Dichter \& Shapiro, 226.

357) Tivolian waltz. New York: E. Riley [1826-31]. Uncataloged (Music book marked Harriet A. Stanton).

1 p. Piano solo.

Dating: Dichter \& Shapiro, 226, not in Wolfe.

358) We met! Ballad from the songs of the boudoir. Sung by Miss Paton. Written and composed by Thomas H. Bayly, Esqr. New York: E. Riley [1826-31]. Uncataloged (Music book signed Harriot A. Stanton).

2 pp. Voice w/piano acc.

Blue paper.

Dating: Dichter \& Shapiro, 226, not in Wolfe.

359) Where, where is the rover. Ballad sung by Mrs. Waylett, in the opera of Lo Zingaro. The poetry by H.R. Addison. The music composed by Alexander Lee. New York: E. Riley

$3 \mathrm{pp}$. Voice w/piano acc.

Stamp: Sold by P.H. Taylor Richmond V. 
Dating: Dichter \& Shapiro, 226.

360) La zelmire. A favorite dance. New York: Firth \& Hall [1826-31]. Uncataloged (Music book marked Harriet A. Stanton).

1 p. Piano solo.

At foot of page: FIGURE. Chasse cross four forward two cross over Promenade all.

Dating: Dichter \& Shapiro, 192.

361) Araby's daughter. From Lalla Rooke. Composed by G. Kiallmark. New York: E.S. Mesier [1826-32].

$3 \mathrm{pp}$. Voice $w /$ piano acc.

Dating: Dichter \& Shapiro, 188.

362) Comin' thro the rye. A favorite Scotch song. Sung by Mrs. Knight. Arranged by J.F. Hance. New York: E.S. Mesier [1826-32].

$2 \mathrm{pp}$. Voice w/piano acc.

Dating: Dichter \& Shapiro, 188.

363) The fall of Paris. Arranged as a rondino for the piano forte by G. E. Fiorini. New York: E. S. Mesier [1826-32].

3 pp. Piano solo.

Dating: Dichter \& Shapiro, 214.

364) From Greenland's icy mountains, a missionary hymn. By the late Bishop Heber, of Calcutter. Composed \& dedicated to Miss Mary W. Howard of Savannah, Georgia by Lowell Mason. New York: Edward S. Mesier [1826-32].

$2 \mathrm{pp}$. Voice w/piano acc.

Dating: Dichter \& Shapiro, 188.

365) La gaite. A favorite rondo for the piano forte. Composed by F. Kuhlau. New York: E.S. Mesier [1826-32].

3 pp. Piano solo.

Dating: Dichter \& Shapiro, 214.

366) Home! sweet home! Sung by Miss M. Tree, in Clari, or The maid of Milan, at the Theatre Royal Covent Garden. Composed \& partly founded on a Sicilian air by Henry R. Bishop. New York: E.S. Mesier [1826-32].

$3 \mathrm{pp}$. Voice $\mathrm{w} /$ piano acc.

Mesier republished this work from George Bacon's print; see Dichter \& Shapiro, pl. no. 9. Dating: Dichter \& Shapiro, 188.

367) The hunter's signal horn. Tyrolese song sung by Mrs. Knight. The music arranged by Alexr. Lee. New York: E.S. Mesier [1826-32].

$4 \mathrm{pp}$. Voice w/piano acc.

Page 1: cue for corni.

Dating: Dichter \& Shapiro, 188.

368) I'd be a dove. Written by Harry Stoe van Dyke. Composed by John Barnett. New York: E.S. Mesier [1826-32].

$3 \mathrm{pp}$. Voice w/piano acc. 
Dating: Dichter \& Shapiro, 214.

369) I lo'e nae a laddie but ane. A Scotch ballad arranged expressly for Miss Stephens by John Parry. New York: E.S. Mesier [1826-32].

$4 \mathrm{pp}$. Voice w/piano or harp acc.

Dating: Dichter \& Shapiro, 214.

370) I'll watch for thee from my lonely bow'r. Ballad. Adapted to a German air the symphonies \& accompaniments by Sir J.A. Stevenson. New York: E.S. Mesier [1826-32]. 3 pp. Voice w/piano acc.

Dating: Dichter \& Shapiro, 214.

371) The invincibles. Written expressly for Made. Vestris, by J.M. Rycott Esq. Sung by Miss Clara Fisher. New York: E.S. Mesier [1826-32].

4 pp. Voice w/piano acc.

T.P. lithograph by Mesier showing two swordsmen and eight soldiers, the last reading from a book.

Dating: Dichter \& Shapiro, 214.

372) Kinlock of kinlock. A favorite Scotch air. Arranged with variations for the piano forte or harp. New York: E.S. Mesier [1826-32].

$3 \mathrm{pp}$. Voice w/piano or harp acc.

Dating: Dichter \& Shapiro, 214.

373) The lavender girl. New York: E.S. Mesier [1826-32].

$1 \mathrm{p}$. Voice w/piano acc.

Dating: Dichter \& Shapiro, 214.

374) Love was once a little boy. Sung with great applause by Mrs. F. Knight. New York: E.S. Mesier [1826-32].

2 pp. Voice w/piano acc.

Title page vignette of angel.

Dating: Dichter \& Shapiro, 188.

375) March to the battle field. Scotch ballad. Sung with great applause by Mr. Horn. New York: E.S. Mesier [1826-32].

2 pp. Voice w/piano acc.

Dating: Dichter \& Shapiro, 214.

376) March to the battle field. Scotch ballad. Arranged for the Spanish guitar by J.

Tanner. New York: E.S. Mesier [1826-32].

2 pp. Voice w/guitar acc.

Dating: Dichter \& Shapiro, 214.

377 Meet me by moonlight. Serenade. Arranged for the Spanish guitar by J. Tanner. New York: E.S. Mesier [1826-32].

2 pp. Voice w/guitar acc.

Dating: Dichter \& Shapiro, 214. 
378) $O$ never fall in love. As sung by Miss Clara Fisher with the most unbounded applause at the Park Theatre in the musical farce of the Invincibles. Composed by Alexr. Lee. New York: E.S. Mesier [1826-32].

7 pp. (page 2 is blank) Voice w/piano acc.

P. 3 t.p.: Never fall in love.

Dating: Dichter \& Shapiro, 214.

379) The plain gold ring. The words by W. T. Moncrieff Esq. Adapted to an air in Der Freyshutz by C.M. von Weber. New York: Mesier [1826-32].

3 pp. Voice w/piano acc.

Dating: Dichter \& Shapiro, 188 (assuming this sheet was published by E.S. Mesier).

380) Rose of Lucerne. Or the Swiss toy girl. Sung by Miss Love. Arranged from an original Swiss melody by John Barnett. New York: E.S. Mesier [1826-32].

$5 \mathrm{pp}$. Voice w/piano acc.

Title page lithograph signed J.G.C.

Dating: Dichter \& Shapiro, 188.

381) Rose of Lucerne. Or the Swiss toy girl. Sung by Miss Love. Arranged from an original Swiss melody by John Barnett. New York: E.S. Mesier [1826-32]. 2nd copy has the identical illustration except that the hair is shorter on the main figure, a girl.

$5 \mathrm{pp}$. Voice w/piano acc.

Title page lithograph signed J.G.C.

Dating: Dichter \& Shapiro, 188.

382) The soldiers grave. Monody on the death of Sir John Moore. Poetry by the Rev Chas. Wolfe. The music by Thomas Williams. New York: E.S. Mesier [1826-32].

5 pp. Voice w/piano acc.

Dating: Dichter \& Shapiro, 188.

383) Wha'll be king but Charlie. A favorite Scotch ballad. Sung by Mr. Keene, the words by Sir Walter Scott. Adapted \& arranged for the piano forte by Haydn Corri. New York: E.S. Mesier [1826-32]

$3 \mathrm{pp}$. Voice w/piano acc.

Page one: Fagotti cue.

Dating: Dichter \& Shapiro, 214.

384) Hark! hark! through the wild wood. The celebrated Tyrolese war song as sung by Madame Vestris. The music by Alexander Lee. Boston: John Ashton [1826-33].

3 pp. Voice w/piano acc.

Dating: Dichter \& Shapiro, 167.

385) The Arab maid. sung by Mrs. Gill. The words by W. McGhie. Composed by G. A. Hodson. New York: Mesier [1826-34]. Uncataloged (Music book signed Harriot A.

Stanton).

$3 \mathrm{pp}$. Voice $w /$ piano acc.

Flute cue, p. 1.

Dating: Dichter \& Shapiro, 214. 
386) Oh! no I'll never mention him. Arranged for the Spanish guitar by JNo. Tanner. New York: E.S. Mesier [1826-34].

1 p. Voice w/guitar acc.

Dating: Dichter \& Shapiro, 214.

387) The Swiss girl. A ballad. With accompaniments for the piano forte by J. Moschelles.

New York: Mesier [1826-34].

2 pp. Voice w/piano acc.

Dating: Dichter \& Shapiro, 214.

388) Aria alla scozzese con variazione. For the piano forte by T. Valentine. Philadelphia: George Willig [1826-51].

4 pp. Piano solo.

Stamp: Sold by J. W. Randolph \& Co. Booksellers, Richmond Virginia.

Dating: Dichter \& Shapiro, 244.

389) Blue eyed Mary. Philadelphia: Geo. Willig [1826-51].

$1 \mathrm{p}$. Voice w/piano acc.

Dating: Dichter \& Shapiro, 244.

390) Blued eyed Mary. Philadelphia: Geo. Willig [1826-51]. 2nd copy.

1 p. Voice w/piano acc.

Dating: Dichter \& Shapiro, 244.

391) The cottage rondo. Composed for the piano forte by M. Holst. Philadelphia: G. Willig [1826-51].

$4 \mathrm{pp}$. Voice w/piano acc. Composed by Matthias von Holst.

Yellow paper.

Dating: Dichter \& Shapiro, 244.

392) The downfall of Paris. Philadelphia: Geo. Willig [1826-51].

1 p. Piano solo.

The imprint Geo Willig 171 Chesnut Street as be printed over the original imprint.

Dating: Dichter \& Shapiro, 244.

393) Farewell since we must part. A favourite German Air. Arranged for the Spanish guitar by J.G. Osbourn. Philadelphia: Geo. Willig [1826-51].

1 p. Voice w/piano or guitar acc.

Dating: Dichter \& Shapiro, 244.

394) Feast of roses. Words by Thomas Moore Esqr. Arranged for the piano forte. Philadelphia: George Willig [1826-51].

2 pp. Voice w/piano acc.

Dating: Dichter \& Shapiro, 244.

395) The gallant troubadour. A favourite French air arranged for the Spanish guitar.

Philadelphia: Geo. Willig [1826-51].

1 p. Voice w/piano acc.

Dating: Dichter \& Shapiro, 244. 
396) Go George I cant endure you. A favourite song in the comic opera No Song No Supper. arranged for the piano forte. Philadelphia: Geo. Willig [1826-51]. 2 pp. Voice w/piano acc.

Dating: Dichter \& Shapiro, 244.

397) The highland bride. A ballad. As sung with unbounded applause by Miss Love. Written by W. Mc. G. Logan. Arranged by John Barnett. Philadelphia: Geo. Willig [182651].

2 pp. Voice w/piano acc. Composed by Stephen Storace.

At bottom of p. 1: Entered according to Law.

Dating; Dichter \& Shapiro, 244.

398) The highlanders chorus. Arranged for the Spanish guitar by J. G. Osbourn. Philadelphia: Geo. Willig [1826-51]

1 p. Guitar solo.

Includes: Grant's guitar waltz and Maria's favorite.

Dating: Dichter \& Shapiro, 244.

399) Home! Sweet Home! Philadelphia: G. Willig [1826-51]. Catalog \#151556.

1 p. Voice w/piano.

Dating: Dichter \& Shapiro, 244.

400) I've been roaming. A cavatina. Sung by Madame Vestris \& Miss L. Gillingham.

Inscribed to Gibson Stott Esqr. by C. E. Horn. Philadelphia: G. Willig [1826-51]. 5 pp. Voice w/piano acc.

Dating: Dichter \& Shapiro, 244.

401) The invitation. The words by Shakespear. Music by Geo. Emrick. Philadelphia: G. Willig. [1826-51]. Uncataloged (Music book signed Harriot A. Stanton).

1 p. voice w/piano acc.

At foot of page: PHILADELPHIA Published by G. Willig.

Probably copied from Come live with me by George Emrick published by William

M'Culloch of Philadelphia in 1807 in his collection entitled Selected Music.

Dating: Dichter \& Shapiro, 244.

402) 'Twas within a mile of Edinburgh. A favourite Scotch song. Philadelphia: Geo. Willig [1826-51].

1 p. Voice w/piano acc.

Dating: Dichter \& Shapiro, 244.

403) Kitty Clover. Sung with unqualified approbation by Mr. Knight. Philadelphia: Geo. Willig [1826-51].

$1 \mathrm{p}$. Voice $\mathrm{w} /$ piano acc.

At bottom of p. 1: N.B. This is the only correct and authorised Edition. Entered according to the acts of congress.

Dating: Dichter and Shapiro, 244.

404) The Maltese boatman's song. For one two or three voices by L. Devereaux.

Philadelphia: G. Willig [1826-51].

4 pp. 3 voices w/piano acc. 
Lithograph of three men in a boat.

Cue for convent bell.

Dating: Dichter \& Shapiro, 244.

405) The Marseilles hymn. A favourite French national air. Philadelphia: Geo. Willig [1826-51].

2 pp. Voice w/piano acc. Text in English and French.

Dating: Dichter \& Shapiro, 244.

406) Mary's dream or Sandy's ghost. Philadelphia: G. Willig [1826-51]. Catalog \#151491. 1 p. Voice w/piano acc.

Stamp: Sold by J.W. Randolph \& Co. booksellers Richmond, Va.

Dating: Dichter \& Shapiro, 244.

407) The Mexican waltz. For the piano forte by C. Meineke. Philadelphia: Geo. Willig [1826-51].

2 pp. Piano solo.

Dating: Dichter \& Shapiro, 244.

408) Moran's favourite variations to the Suabian air for the harp or piano forte.

Philadelphia: Geo. Willig [1826-51].

5 pp. Piano solo.

In the lower margin of p. 2: The small notes are for the piano forte, the others for the harp.

Dating: Dichter \& Shapiro, 244. Probably a re-issue of Willig's publication of $1817-19$, see

Wolfe, II, 596, \#6111.

409) The mountain maid. A ballad introduced by Madame Vestris at the theatre royal haymarket in the burletta of Midas. Philadelphia: G. Willig [1826-51].

3 pp. Voice w/piano acc.

Dating: Dichter \& Shapiro, 244.

410) Negro Dance, no. 1; The coquette, no. 2; The colly flower, no. 3. Philadelphia: Geo. Willig [1826-51].

1 p. Piano solo.

Dating: Dichter \& Shapiro, 244.

411) On younder rock reclining. A Rondo from the Celebrated Opera of Fra Diavolo, Sung by Mr. \& Mrs. Wood. Philadelphia: Geo. Willig [1826-51].

$4 \mathrm{pp}$. Voice w/piano acc.. A.F. Winnemore Engr. Winnemore is not listed in Wolfe. Dating: Dicther \& Shapiro, p. 244, and not listed by composer in Wolfe.

412) Pensez a moi ma chere amie. Arranged for the Spanish guitar by J.G. Houston. Philadelphia: Geo. Willig [1826-51].

1 p. Voice w/piano acc.

Dating: Dichter \& Shapiro, 244.

413) Sandy and Jenny. A favourite Scotch song. Philadelphia: Geo. Willig [1826-51]. 1 p. Voice w/piano acc.

Dating: Dichter \& Shapiro, 244. 
414) She is Thine, Ballad, Sung by Mrs. Wood, composed by T. Labarre. Philadelphia: George Willig [1826-51].

$2 \mathrm{pp}$. Voice $w /$ piano acc.

Dating: Dichter \& Shapiro, p. 244, and not listed by composer in Wolfe.

415) The sisters, A collection of popular and esteemed airs. Arranged as duetts, for two performers on the piano forte. Selected from the works of the best composers. No. 14.

Fall of Paris. Philadelphia: George Willig [1826-51].

2 pp. Piano four hands. Composed by F. Hunten.

Dating: Dichter \& Shapiro, 244.

416) The Swiss boy. A ballad with accompaniments for the piano forte. Arranged by J. Moscheles. Philadelphia: Geo. Willig [1826-51].

2 pp. Voice w/piano acc. Arranged by Ignaz Moscheles.

Dating: Dichter \& Shapiro, 244.

417) The tooth ache. A new favorite air. Composed expressly for the piano forte by James G. Osbourn. Philadelphia: Geo. Willig [1826-51].

1 p. (incomplete?) Piano solo.

Dating: Dichter \& Shapiro, 244.

418) Treasures of the deep. A ballad by Mirs. Hemans. The music by Mrs. Robt.

Arkwright. Philadelphia: George Willig [1826-51].

$3 \mathrm{pp}$. Voice $\mathrm{w} / \mathrm{piano}$ acc.

Dating: Dichter \& Shapiro, 244.

419) Twilight dews. A favorite song. Arranged with an accompaniment for the piano

forte. Philadelphia: Geo. Willig [1826-51].

$2 \mathrm{pp}$. Voice $\mathrm{w} / \mathrm{piano}$ acc.

Dating: Dichter \& Shapiro, 244.

420) 2nd Edition. Variations on Moore's Favorite Melody Beleive [!] me if all those \&c. or My lodgings is on the cold ground arranged for the piano forte by Valentine.

Philadelphia: George Willig [1826-51].

7 pp. Piano solo.

Dating: Dichter \& Shapiro, 244. Not listed in Wolfe.

421) Von Weber's last waltz. Philadelphia: Geo. Willig [1826-51].

1 p. Piano solo.

Dating: Dichter \& Shapiro, 244.

422) Wandering Willie or here awa there awa. Written by Robert Burns. By Thomas Carr. Philadelphia: George Willig [1826-51].

2 pp. Voice w/piano acc.

Dating: Dichter \& Shapiro, 244. 423) When I was a girl of eighteen years old. Philadelphia: Geo. Willig [1826-51]. Catalog
\#151529.

2 pp. Voice w/piano acc. 
Lithograph on page 1 (woman with parasol and 2 men).

Dating: Dichter \& Shapiro, 244.

424) White's favourite airs. Arranged for the Spanish guitar. Philadelphia: Geo. Willig [1826-51].

1 p. Guitar solo.

The airs are entitled: Herr Cline, Robin Adair, Life let us cherish, Turkish quick step.

Dating: Dichter \& Shapiro, 244.

425) The cheat. Baltimore: Geo. Willig [1826-67].

1 p. Piano solo.

Dating: Dichter \& Shapiro, 244.

426) The Lee Rigg with variations for the piano forte, by Dominico Corri. Baltimore: $G$. Willig [1826-67].

$3 \mathrm{pp}$. (third page damaged). Piano solo.

Pub. no. 651 (not a reliable indicator of date).

Dating: Dichter \& Shapiro, 244.

427) March in the Battle of Prague. Baltimore: G. Willig [1826-67].

1 p. Piano solo. Composed by Franz Koczwara.

Dating: Dichter \& Shapiro, 244.

428) The soldiers joy; Miss McLeod's reel; Tho 'tis all but a dream; My heart and lute. Baltimore: Geo. Willig [1826-67].

$2 \mathrm{pp}$. Piano solo. Composer of Tho 'tis all but a dream is Henry R. Bishop; composer of My heart and lute is Thomas Moore.

Page two: instructions given for dance steps.

Dating: Willig published Tho 'tis all but a dream in an earlier edition from 1824-25; and an earlier edition of My heart and lute from 1824-27 (Wolfe I, 77, \#821; Wolfe II, 585, \#5994).

429) Fra tante angoscie. From the opera of La Cenerentola. Arranged with variations for the piano forte by W. Grosse. New York: Dubois \& Stodart [1827]. Uncataloged (Music book signed Harriot A. Stanton).

5 pp. Piano solo.

Dating: Dichter \& Shapiro, 188.

430) Le joujou. A duet for the flute \& piano forte. Composed \& dedicated to Miss Ainger, by Geo. Hargreaves. New York: Dubois \& Stodart [1827]. Uncataloged (Music book signed Harriot A. Stanton).

6 pp. (half of pp. 2-5 are missing). Flute w/piano acc.

Dating: Dichter \& Shapiro, 188.

431) Kate Kearney. Arranged for the guitar by H. N. Gilles. Baltimore: Geo. Willig Jr. [1827].

1 p. Voice w/guitar acc.

At bottom of page 1: Entered according to act of Congress the 20th day of August 1827 by $\mathrm{G}$. Willig of the state of Maryland.

Dating: copyright notice. 
432) Kate Kearney. A favorite Irish air. Arranged with variations for the piano forte. Baltimore: John Cole [1827].

3 pp. Piano solo.

Pl. no. 279.

At bottom of page 1: Copy right secured according to Act of Congress, April 31827 by John Cole, of the State of Maryland.

Dating: copyright notice.

433) The light guitar. Sung by Signorina Garcia. Composed by J. Barnett. New York:

Dubois \& Stodart [1827].

3 pp. Voice w/piano acc.

Dating: Dichter \& Shapiro, 188.

434) Moss roses. Ballad. Respectfully inscribed to Madame Vestris. Arranged by John Barnet. New York: Dubois \& Stodart [1827].

4 pp. Voice w/piano acc.

Paper label: Sold at Knight's music saloon, Richmond, Va.

Dating: Dichter \& Shapiro, 188.

435) The overture to the favorite opera Der Freyschutz. By C.M. von Weber. Arranged for the piano forte by A. Diabelli. New York: Dubois \& Stodart [1827]. Uncataloged (Music book marked Harriet A. Stanton).

$10 \mathrm{pp}$. Piano solo.

On bottom of p. 1: Sold by C. B. De Riemer \& Co. Auburn.

Stamp: E. Riley / 29 Chatham St. / New York.

On bottom of title page: 10 , indicating a length of 10 pages.

Dating: Dichter \& Shapiro, 188.

436) Return O my love. Sung by Mrs. G. Barrett at the New York Theatre in the melo drama of the Flying Dutchman. The music composed and dedicated to Miss Hosack by Charles Gilfert. New York: E. Riley [1827].

$3 \mathrm{pp}$. Voice w/piano and two flutes acc.

The flute parts are cued in the piano part.

In the lower margin of $\mathrm{p}$. 1: Entered according to Act of Congress, the sixteenth day of August 1827, by Edward Riley of the State of New York.

Dating: Copyright notice.

437) The Swiss boy. A ballad. With accompaniments for the piano forte arranged by J. Moscheles. New York: Dubois \& Stodart [1827]. Uncataloged (Music book signed Harriot A. Stanton).

2 pp. Voice w/piano acc.

Dating: Dichter \& Shapiro, 188.

438) Today, dearest is ours. Ballad. Written by Thomas Moore. The subject of the air from a ballet. New York: Dubois \& Stodart [1827].

2 pp. Voice w/piano acc.

Dating: Dichter \& Shapiro, 188. 
439) Where roses wild were blowing. Arranged for the Spanish guitar. n.p. [possibly

Philadelphia: John G. Klemm, [1827?].

1 p. Voice w/guitar acc.

Page 11 on upper $r$. h. corner.

Pub. no. 321.

Dating: Krummel, 234 (based on pl. no.).

440) Alice Gray. A ballad. Sung by Miss Paton. Composed by Mrs. P. Millard. New York: Bourne [1827-32].

$3 \mathrm{pp}$. Voice w/piano acc.

Pub. no. 102. On p. 3: Engd. \& pr. by S. Ackerman \& Co.

Dating: Dichter \& Shapiro, 174.

441) Alice Gray. A ballad. Sung by Miss Paton. Composed by Mrs. P. Millard. New York: Bourne [1827-32]. Uncataloged (Music book signed Harriot A. Stanton). 2nd copy.

$3 \mathrm{pp}$. Voice w/piano acc.

Pub. no 102. On p. 3: Engd. \& pr. by S. Ackerman \& Co.

Green paper.

Dating: Dichter \& Shapiro, 174.

442) The banks of Allan water. A ballad, as sung by Mrs. Holman. The words by M.G. Lewis Esq. Arranged for the piano forte by C. E. Horn. New York: Bourne [1827-32]. 2 pp. Voice w/piano acc.

Pub. no. 103. On p. 2: Engd. \& pr. by S. Ackerman \& Co.

Dating: Dichter \& Shapiro, 174.

443) The bird waltz. For the harp or piano forte. Composed by Francis Panormo. New

York: Bourne [1827-32]. Uncataloged (Music book signed Harriot A. Stanton).

$3 \mathrm{pp}$. Harp or piano solo.

Dating: Dichter \& Shapiro, 174.

444) "Buy Image!" Ballad. Sung with enthusiastic applause, by Madame Vestris. The words by the Honble T.C. The music, with an accompaniment for the piano forte, by G. Maddison. New York: E.S. Mesier 28 Wall St. and Bourne Broadway 359 [1827-32].

$6 \mathrm{pp}$. Voice w/piano acc.

Lithograph illustration (probably by Mesier) showing the shops of Mesier and Bourne next to each other, and a man selling dolls in the street.

Page 1 title: "Buy image!" Sung by Miss Clara Fisher.

Dating: Dichter \& Shapiro, 174, 214.

445) Green hills of Tyrol. The celebrated Tyrolien in the grand opera of Guillaume Tell. Composed by Rossini. Sung by Miss Melton at the oratorios, \&c. The poetry by George Linley Esqr. The alteration \& expression by T. Rovedino. New York: Bourne [1827-32]. $6 \mathrm{pp}$. Voice $\mathrm{w} / \mathrm{piano}$ acc.

Pub. no. 182.

Cue for flute, p. 2.

Dating: Dichter \& Shapiro, 174.

446) La Fayette's grand march for the piano forte by W.R. Coppock. New York: Bourne [1827-32]. Catalog \#151541. 
2 pp. Piano solo.

Dating: Dichter \& Shapiro, 174.

447) Run! Jerry, run! New York: Bourne [1827-32].

1 p. Voice w/piano acc.

Dating: Dichter \& Shapiro, 174.

448) The spring time is come. A Spanish air with symphonies \& accompaniments by W. Nash. New York: Bourne [1827-32]. Uncataloged (Music book signed Harriot A.

Stanton).

3 pp. Voice w/piano acc.

Pub. no. 114.

Pink paper.

Dating: Dichter \& Shapiro, 174.

449) The vintagers evening hymn. For one, two, or three voices. Composed by S. Nelson. New York: Bourne [1827-32].

3 pp. 3 voices w/piano acc.

Pink paper and lithograph signed Gimber, del. Lith. of Pendleton.

Dating: Dichter \& Shapiro, 174.

450) We met! A ballad from the Songs of the Boudoir. As sung by Miss Paton. Written and Composed by Thomas H. Bayly, Esqr. New York: Bourne [1827-32].

2 pp. Voice w/piano acc.

Pub. no. 28. Engrd. by T. Birch.

Dating: Dichter \& Shapiro, 174.

451) The battle of Prague. A favorite sonata for the piano forte. Composed by F.

Kotzwara. Boston: C. Bradlee [1827-34].

10 pp. (page 2 blank). Piano solo.

Dating: Dichter \& Shapiro, 175.

452) John Anderson my Jo. A Scotch air sung by Sinclair. Arranged by Kozeluch. Boston: C. Bradlee [1827-34]. Catalog \#151525.

3 pp. Voice w/piano acc.

Lithograph on t.p. by Pendleton's lithography, Boston.

Stamp: Sold at G. Willig's Musical Magazine Philad.

Dating: Dichter \& Shapiro, 175.

453) The pilgrim fathers. Words by Mrs. Hemans. Music by Miss Browne, sister of Mrs.

Hemans. Boston: C. Bradlee [1827-34].

$6 \mathrm{pp}$. Voice w/piano acc.

Stamp; sold at G. Willig's 171 Chestnut St. PHILAD.

Dating: Dichter \& Shapiro, 175.

454) The pilgrim fathers. Words by Mrs. Hemans. Music by Miss Browne, sister of Mrs. Hemans. Boston: C. Bradlee [1827-34]. Uncataloged (Music book marked Harriet A.

Stanton). 2nd copy.

6 pp. Voice w/piano acc.

Dating: Dichter \& Shapiro, 175. 
455) Variations for the piano forte on a favorite dance The Soldiers Joy. Composed \& dedicated to Miss Martha Strang of St. Andrews, N.B. By James Hooton. Boston: C. Bradlee [1827-34]. Uncataloged (Music book marked C.A. Stewart).

6 pp. Piano solo.

Dating; Dichter \& Shapiro, 175.

456) Boston independent cadets' grand march. Composed by J. Kuffner. Arranged for the piano forte by J. Worsley. Boston: C. Bradlee [1828].

2 pp. Piano solo.

At the bottom of p. 1: "Entered according to Act of Congress in the year 1828 by C.

Bradlee in the Clerk's office of the Distet Court of Massachusetts."

Dating: copyright notice.

457) Evening song of the Tyrolese peasants. The words from the forget me not by Mrs. Hemans. The music expressly composed \& arranged for the piano forte and dedicated to George Cadwalader Esq. by I. T. Norton. Philadelphia: Geo. Willig [1828].

3 pp. Voice w/piano acc.

At the bottom of p. 1: Entered according to Act of Congress the thirtieth day of January

1828 by Geo Willig of the State of Pennsylvania.

Dating: Copyright notice.

458) A grand Russian march for the piano forte. Dedicated with permission to Miss Eliza Stenart. New York: E. Riley [1828]. Uncataloged (Music book marked C.A. Stewart). 3 pp. Voice w/piano acc.

Bottom of p. 1: Entered according to Act of Congress the tenth day of July 1828 by

Edward Riley of the state of New York.

Dating: Copyright notice.

459) The hunting chorus from Der Freyschutz. Arranged for one voice with accompts. for a flute \& piano forte by A. Professor. New York: E. Riley [1828].

$4 \mathrm{pp}$. Voice w/flute and piano acc.

At bottom of p. 1: Entered according to Act of Congress, the twenty-ninth day of October 1828, by Edward Riley of the State of N.Y.

Dating: copyright notice.

460) Love has been there. Arranged for the Spanish guitar by B.F. Peale. Philadelphia:

Geo. Willig [1828].

1 p. Voice w/guitar acc.

Page 2, upper r.h. cor.

At bottom page: Entered according to Act of Congress the twenty first day of August 1828 by Geo. Willig of the State of Pennsylvania.

Dating: Copyright notice.

461) Mild as the Moonbeams. The celebrated quartett in Artaxerxes. Arranged for one voice with accompaniments for the piano forte by P.K. Moran. New York: Dubois \& Stodart [1828].

6 pp. Voice w/piano acc. Composed by Thomas Arne, arranged by Peter K. Moran. At bottom of t.p.: Entered according to Act of Congress the fifteenth day of April 1828 by Dubois \& Stodart New York. 


\section{Dating: copyright notice.}

462) My sweet my blue eyed Mary. The words by Bishop Heber. Composed for the Spanish guitar by Franklin Peale. Philadelphia: Geo. Willig [1828].

1 p. Voice w/guitar acc.

Page 3 upper r.h. cor.

Marked Troubadour, n.2.

At bottom of page: To be played in Eb with the Capo de Astro on the 1st fret or it may be play'd as written in D. Entered according to Act of Congress the twenty first day of

August 1828 by Geo. Willig of the State of Penn.

Dating: Copyright notice.

463) Ode to Washington. Composed \& dedicated to the Handel \& Haydn

Society of Boston by Charles E. Horn. New York: Dubois \& Stodart [1828].

31 pp. Piano solo, voice w/piano acc., 4-part chorus w/piano acc.

Contents: pp. 3-4: Marcia funebre; 5: recitative; 6-7: chorus; 8- 11: O ne'er to man. Sung

by Mr. Horn in The Ode to Washington. Composed by C. E. Horn; 12-14: As some found Mother. Sung by Mrs. Knight in the Ode to Washington. Accompanied on the violin by Mr. Ostinelli. Composed by C.E. Horn; 15-23: chorus; 24-27: The pearly drops. A duett. Sung by Mrs. Knight \& Miss E. Gillingham in the Ode to Washington. Composed by C.E. Horn; 28: recitative; 29: finale; 30-31 chorus.

Includes brown wrapper cover.

Dating: Copyright notice of Dec. 8, 1828 on verso of t.p. and on the bottom of pp. 8, 12, 24.

464) Oh never fall in love. As sung by Miss Clara Fisher. Arranged for the Spanish guitar by T.E. Cubbert. Philadelphia: Geo. Willig [1828].

2 pp. Voice w/guitar acc.

At top of p. 1: Entered according to Act of Congress the 3d. day of October 1828 by Geo. Willig of the State of Pennsylvania.

Dating: Copyright notice.

465) La serenade. A selection of popular songs arranged with accompaniments for the Spanish guitar, by T.E. Gubert. Philadelphia: Geo. Willig [1828].

7 pp. Voice w/guitar acc.

Contents: p. 2: The Swiss boy, A Ballad.; p. 3: The Swiss girl. A Ballad; pp. 4-5: Oh young maiden hearts beware. Sung by Signorina Garcia; p. 6: Yes I will leave my father's halls. The air from Der Freyschutz; p. 7: The ingle side. A favourite Scotch song. La serenade no. 2.

The t.p. and title pages of each song includes the following: Entered according to Act of Congress the $3 \mathrm{~d}$. Day of October 1828 by Geo. Willig of the State of Pennsylvania. Dating: copyright notice.

466) A soldier's the lad I adore. Written for and dedicated to Miss Rock. And sung by her with universal applause adapted to the original French air of Le Petit Tambour. Words \& accompaniment by J.H. Hewitt. Baltimore: Geo. Willig Junr. [1828].

3 pp. Voice $w /$ piano acc.

In lower margin: Entered according to Act of Congress the $3 \mathrm{~d}$ day of November 1828 by George Willig Junr of the state of Maryland.

Dating: Copyright notice. 
467) Twilight Dews. A favorite French air. Arranged for the Spanish guitar by B.F. Peale. Philadelphia: Geo. Willig [1828].

$1 \mathrm{p}$. Voice $\mathrm{w} /$ guitar acc.

At bottom of p. 1: With an accompaniment written in $\mathrm{C}$ to be played in $\mathrm{Eb}$, with the CAPO DE ASTRO on the 3d. fret. Entrd according to Act of Congress the twenty first day of August 1828 by Geo. Willig of the State of Pennsylvania.

Dating: copyright notice.

468) The wandering harper. Composed by B. Carr. Arranged for the Spanish guitar by Franklin Peale. Philadelphia: Geo. Willig [1828].

1 p. Voice w/guitar acc. Composed by Benjamin Carr.

Page 6 upper l.h. cor.

At bottom of page: Entered according to Act of Congress the twenty first day of August 1828 by Geo. Willig of the State of Penn.

Dating: Copyright notice.

469) The wandering harper. Composed by B. Carr. Arranged for the Spanish guitar by Franklin Peale. Philadelphia: Geo. Willig [1828]. 2nd copy.

1 p. Voice w/guitar acc. Composed by Benjamin Carr.

Page 6 upper l.h. cor.

At bottom of page: Entered according to Act of Congress the twenty first day of August 1828 by Geo. Willig of the State of Penn.

Dating: Copyright notice.

470) All the blue bonnets are over the border. A national Scotch song. Sung by Mr. Horn, with unbounded applause. Philadelphia: John G. Klemm [1828?].

$4 \mathrm{pp}$. Voice/w piano acc.

Pub. no. 348.

Dating: Krummel, 234 (based on pub. no.).

471) I'd be a butterfly. A ballad. Sung with great applause by Mrs. Sharpe. Composed by T.H. Bayley. New York: A. Fleetwood [1828-30].

$4 \mathrm{pp}$. Voice w/piano acc.

Dating: Dichter \& Shapiro, 193.

472) A new arrangement of the overture to the Caliph of Bagdad, for the piano forte by M. Boieldieu. With accompts. for the flute, or violin, ad lib. New York: E. Riley [182831]. Uncataloged (Music book signed Harriot A. Stanton).

$7 \mathrm{pp}$. (missing page 7 and flute or violin parts). Piano solo.

Dating: Dichter \& Shapiro, 226; Odell III, 710 (Caliph of Bagdad first performed in 1828 in New York).

473) La Parisienne. Music by Auber. Arranged for the piano forte by Thos. Valentine. New York: Dubois \& Stodart [1828-32].

2 pp. Piano solo.

P. 1: cue Sym:

Dating: Dichter \& Shapiro, 188. 
474) A popular Swiss air. Arranged \& varied for the piano forte, and most respectfully inscribed to Mrs. Henry Harpur, by R. Schroeder. New York: Dubois \& Stodart [182832].

3 pp. Piano soio.

Dating: Dichter \& Shapiro, 188.

475) When morning like a blushing bride. A national rondo. Sung with unbounded applause by Mrs. Knight. The poetry by Mr. F. Hill. Adapted arranged and dedicated to Mrs. Morse (New Orleans) by Edwd. Knight. New York: Dubois \& Stodart [1828-32]. $4 \mathrm{pp}$. Voice w/piano acc.

Dating: Dichter \& Shapiro, 188.

476) Annot Lyle. Ballad. Written by J. O. Donoghue Esq. Composed by G.A. Hodson. New York: Dubois \& Stodart [1828-34].

$2 \mathrm{pp}$. Voice $w /$ piano acc.

Dating: Dichter \& Shapiro, 188.

477) Bochsa's celebrated march. Describing the advance $\&$ retreat of a military band for the piano forte. Arranged by S.T. Rosenberg. New York: Dubois \& Stodart [1828-34]. Uncataloged (Music book marked Harriet A. Stanton).

5 pp. Piano solo.

On p. 1: To be played so as to imitate the approach and retreat of a Band.

Cues for flutes, bugles and drums.

Dating: Dichter \& Shapiro, 188.

478) C'est l'amour. Arranged as an easy rondo for the piano forte. By T. Valentine. New York: Dubois \& Stodart [1828-34]. Uncataloged (Music book marked C.A. Stewart).

3 pp. Piano solo.

Dating: Dichter \& Shapiro, 188.

479) Come, dearest at ev'ning hour. A song written by G. B. White Esqr. Composed and dedicated to Mrs. Julia Griswold, by Wilhelm Incho. New York: Dubois \& Stodart [182834].

$3 \mathrm{pp}$. Voice w/piano acc.

Dating: Dichter \& Shapiro, 188.

480) Gaily the troubadour touch'd his guitar. Composed \& arranged for the piano forte by T.H. Bayly. New York: Dubois \& Stodart [1828-34].

2 pp. Voice w/piano acc.

Dating: Dichter \& Shapiro, 188.

481) The fall of Paris. A military air. Arranged with variations for the piano forte. By I. Moscheles. New York: Dubois \& Stodart [1828-34]. Uncataloged (Music book marked C.A. Stewart).

17 pp. Piano solo.

Dating: Dichter \& Shapiro, 188.

482) Her heart is not there. A popular ballad. Composed expressly for Mrs. Wood. By G.A. Hodson. New York: Dubois \& Stodart [1828-34]. Uncataloged (Music book marked Harriet A. Stanton). 
4 pp. Voice w/piano acc.

Dating: Dichter \& Shapiro, 188.

483) Home! Sweet home. Ballad in Clari, or the Maid of Milan. Arranged by Henry R. Bishop. New York: Dubois \& Stodart [1828-34]. Catalog \#151555.

3 pp. Voice w/piano acc.

Dating: Dichter \& Shapiro, 188.

484) Hunter of Tyrol. Sung by Mrs. Waylett. Written by Charles Jefferys Esqr. Composed by S. Nelson. New York: Dubois \& Stodart [1828-34]. Uncataloged (Music book marked Harriet A. Stanton).

$3 \mathrm{pp}$. Voice w/piano acc.

Cue for Corni p. 1.

Stamp: E. RILEY / 29 Chatham St. / N-Y.

Dating: Dichter \& Shapiro, 188.

485) In happier hours. "Melodies of various nations" The poetry by T.H. Bayly Esq. The symphonies \& accompaniments by Henry R. Bishop. New York: Dubois \& Stodart [182834]. Catalog \#151558.

$3 \mathrm{pp}$. Voice w/piano acc.

Stamp: Sold by W. Daniell, Richmond, VA.

Dating: Dichter \& Shapiro, 188.

486) The lass wi the bonny blue E'en. The favorite Scottish ballad. sung by Mr. Sinclair at the Park Theatre. Arranged and partly composed by J. Sinclair. New York: Dubois \& Stodart [1828-34]. Uncataloged (Music book signed Harriot A. Stanton).

$5 \mathrm{pp}$. Voice w/piano acc.

Dating: Dichter \& Shapiro, 188.

487) Love's Ritomella. Written by J. R. Planche Esq. Composed by T. Cooke. New York: Dubois \& Stodart [1828-34].

3 pp. Voice w/piano acc. Composed by Thomas Simpson Cooke.

Dating: Dichter \& Shapiro, 188.

488) March from Masaniello by Auber. Arranged by Chaulieu. New York: Dubois \& Stodart [1828-34]. Uncataloged (Music book signed Harriot A. Stanton).

2 pp. Piano solo.

Dating: Dichter \& Shapiro, 188.

489) Military rondo for the piano forte. Arranged by B. Viguerie. New York: Dubois \& Stodart [1828-34]. Uncataloged (Music book signed Harriot A. Stanton).

2 pp. Piano solo.

Dating: Dichter \& Shapiro, 188.

490) National guards march and rondo for the piano forte. Composed \& arranged by P.K. Moran. New York: Dubois \& Stodart [1828-34]. Uncataloged (Music book marked Harriet A. Stanton).

4 pp. Piano solo.

On bottom of first page: Sold by C. B. De Riemer \& Co. Auburn.

Stamp: E. Riley / 29 Chatham St. / New York. 
On bottom of first page 4: indicating the number of pages.

Dating: Dichter \& Shapiro, 188.

491) Oh! no we never mention her. As sung by Mr. Pearman. Written by T.H. Bayly Esq. Arranged by Henry R. Bishop. New York: Dubois \& Stodart [1828-34]. Catalog \#151546.

$2 \mathrm{pp}$. Voice $\mathrm{w} /$ piano acc.

Dating: Dichter \& Shapiro, 188.

492) O' they marchd thro' the town. Sung by Madame Vestris. The words by T. H. Bayly. Composed by S. Nelson. New York: Dubois \& Stodart [1828-34].

$3 \mathrm{pp}$. Voice w/piano acc.

Pub. no. 3.

Dating: Dichter \& Shapiro, 188.

493) The rose of Allandale. Ballad. Written by Charles Jeffery. The Music by S. Nelson.

New York: Dubois \& Stodart [1828-34].

3 pp. Voice w/piano acc.

Dating: Dichter \& Shapiro, 188.

494) Une soiree du vaudeville. Quadrilles arranges pour le piano forte. Et dedies a Mme. Elie Mathieu. Par A. Flottes. New York: Dubois \& Stodart [1828-34]. Uncataloged

(Music book marked Harriet A. Stanton).

$6 \mathrm{pp}$. Piano solo.

Stamp: Sold by J.L. Hewitt 137 Broadway New York.

Dating: Dichter \& Shapiro, 188.

495) Valse du Turc in Italie. A rondinetto for the piano forte. Arranged by H. Lemoine. New York: Dubois \& Stodart [1828-34].

5 pp. Piano solo.

Dating: Dichter \& Shapiro, 188.

496) When you're roaming. An answer to the celebrated cavatina I've been roaming. Sung with unbounded applause by Mrs. Knight. Composed by C. E. Horn. New York: Dubois \& Stodart [1828-34].

4 pp. Voice w/piano acc.

Dating: Dichter \& Shapiro, 188.

497) The white cockade. Arranged as an easy rondo for the piano forte by T. Valentine. New York: Dubois \& Stodart [1828-34]. Uncataloged (Music book signed Harriot A. Stanton).

3 pp. Piano solo.

Dating: Dichter \& Shapiro, 188.

498) Oh! come my love along the sea. Arranged for the Spanish guitar by J. Lhulier.

Professor of the lyre and guitar. Philadelphia: G. Willig [1829].

2 pp. Voice w/guitar acc.

On the top of p. 1: Entered according to Act of Congress the sixteenth day of March 1829 by George Willig of State of Pennsylvania.

Dating: Copyright notice. 
499) Ship a hoy! A ballad. Written by Thomas Moore Esqr. Arranged by P. K. Moran. New York: Dubois \& Stodart [1829].

$3 \mathrm{pp}$. Voice $\mathrm{w} / \mathrm{harp}$ or piano acc.

On first page below imprint information: Entered according to Act of Congress the fourth day of August 1829 by Dubois \& Stodart New York.

Dating: Copyright notice.

500) There's nothing true but Heaven. A favourite song from Moore's Sacred Melodies. Composed by O. Shaw. Providence: the Author [1829]. Uncataloged (Music book marked M.S. Hereford).

$2 \mathrm{pp}$. Voice w/piano acc.

On p. 1: Entered according to Act of Congress in the year 1829 by Oliver Shaw in the Clerk's office of the District Court of R.I.

Stamp: E. RILEY / N.Y.

Dating: copyright notice.

501) The Arab Steed. A ballad. Sung by Madame Feron. Composed by G. A. Hodson. Philadelphia: John G. Klemm [ca. 1829]

$3 \mathrm{pp}$. Voice w/piano acc.

Pub. no. 440.

502) Ther's Nothing True but Heav'n. No publisher given [ca. 1829].

1 p. Voice $w /$ piano acc. Three verses.

Probably copied from the publication by O. Shaw in 1829 .

Dating: Krummel, Supplement, 182, based on pub. no.

503) Silent oh Moyle! Arranged for the piano forte by L. Meignen. Philadelphia: John G. Klemm [ca. 1829].

2 pp. Voice w/piano acc.

Pub. no. 489.

Dating: Krummel, Supplement, 183, based on pub. no.

504) Star Spangled Banner. Baltimore: Geo. Willig [ca 1829]. Catalog \#433181.

1 p. Voice w/piano acc.

Stamp: J.F. Nunns Music \& Piano Store [New York].

Dating: Wolfe II, 821, \#8349A.

505) Wery pekooliar, or the lisping lover. A comic song. Written by J. Beuler Esqr.

Arranged for the piano forte by J. Blewitt. Baltimore: John Cole [ca. 1829].

$3 \mathrm{pp}$. Voice $\mathrm{w} / \mathrm{piano}$ acc.

Pub. no. 439.

Dating: Based on pub. no.

506) Neapolitan Dance. From the opera of Masaniello. Arranged as a rondo for the piano forte by M. Fiorelli. New York: E. Riley [1829-31]. Uncataloged (Music book signed Harriot A. Stanton).

3 pp. Piano solo.

Dating: Dichter \& Shapiro, 226; Odell III, 729 (Masaniello was first performed in New York in 1829). 
507) Oh give me but my Arab steed. Favorite polacca as sung by Miss Cramer. Words by W. McGhie. Composed by G.A. Hodson. New York: Firth \& Hall [1829-31].

3 pp. Voice w/piano acc.

Stamp: Sold by J.L. Hewitt 137 Broadway, N. York.

Dating: Dichter \& Shapiro, 192.

508) The chaplet. A waltz flora. Philadelphia: R.H. Hobson and Washington: Pishey Thompson [1829-33]. Catalog \#151519.

1 p. Piano solo.

The flowers of the tree indicate notes, the key signature includes bees to indicate sharps.

Dating: Dichter \& Shapiro, 207 [for Hobson].

509) The watchman. Arranged for the Spanish guitar by A. Schmitz. Philadelphia: R. H. Hobson [1829-33].

1 p. Voice w/guitar acc.

Dating: Dichter \& Shapiro, 207.

510) Wilt thou meet me there love. Arranged for the Spanish guitar by A. Schmitz. Philadelphia: R.H. Hobson [1829-33].

2 pp. Voice w/guitar acc.

Dating: Dichter \& Shapiro, 207.

511) Bonnie Doon. A favorite Scotch song for one or two voices. Arranged for the piano forte. New York: Geib \& Walker [1829-42].

$2 \mathrm{pp}$. Voice w/piano acc.

Dating: Wolfe I, 100, \#976A. A reissue of the publication by J.A. \& W. Geib [1818-21].

512) The favorite air or $O$ dolce concento. Arranged with variations for the flute by $C$. Nicholson, and performed by E. Cuddy. Adapted with an accompaniment for the piano forte by J. F. Burrowes. New York: Geib \& Walker [1829-42].

9 pp. Flute w/piano acc. Composed by W. A. Mozart.

Re-engraved title page and reissue from publication by Geib \& Co. [1816-17].

Dating: Dichter \& Shapiro, 194.

513) The battle of Prague. A favorite sonata for the piano-forte. Composed by F.

Kotzwara. New York: Geib \& Walker [1829-43]. Uncataloged (Music book marked

Harriet A. Stanton).

8 pp. Piano solo.

Reissue of J. Hewitt's publication of 1807-10.

This issue is not the same as noted in Wolfe II, 496, \#5106D.

Dating: Dichter \& Shapiro, 194.

514) Alice Gray. A ballad. sung by Miss Paton. composed by Mrs. P. Millard. Baltimore: Geo. Willig Jr. [1829-67].

2 pp. Voice w/piano acc.

Dating: Dichter \& Shapiro, 244.

515) Annot Lyle! From the fourth London Edition. Written by J. O. Donoghue Esqr. Baltimore: G. Willig Jr. [1829-67]. 
2 pp. Voice w/piano acc. Composed by G. A. Hodson.

Dating: Dichter \& Shapiro, 244.

516) Bring flowers. The poetry by Mrs. Hemans. Baltimore: Geo. Willig Jr. [1829-67].

2 pp. Voice w/piano acc.

Dating: Dichter \& Shapiro, 244.

517) The Captive Knight. A Ballade. The words by Mrs. Hemans. The music by her sister.

Baltimore: Geo. Willig Jr. [1829-67].

4 pp. Voice w/piano acc. Composed by Harriet Browne.

Lithograph of soldier on horseback and marching troops.

Dating: Dichter \& Shapiro, 244.

518) For me let fall a tear! Ballad. As sung by Madame Cellini, at the nobilities concert.

The music by Robt. Guylott. Baltimore: Geo. Willig Jr. [1829-67].

6 pp. Voice w/piano acc.

Engraver's name given as E.Gillingham.

Dating: Dichter \& Shapiro, 244.

519) Gaily the troubadour touch'd his guitar. Composed \& arranged for the piano forte by T. H. Bayly Esq. Baltimore: Geo. Willig Jr. [1829-67].

2 pp. Voice w/piano acc.

Newspaper clipping "For the New York Journal of Commerce" concerning the death of

Capt. Hale.

Dating: Dichter \& Shapiro, 244.

520) Hurrah for the bonnets of blue. A ballad. Sung by Miss Clara Fisher. Composed by Alexr. Lee. Baltimore: Geo. Wlllig Jr. [1829-67].

3 pp. Voice w/piano acc.

Cue for bugle p. 1.

Dating: Dichter \& Shapiro, 244.

521) The hunter's chorus from Der Freyschutz. Arranged as a rondo. Baltimore: Geo.

Willig Jr. [1829-67].

2 pp. Piano solo.

Dating; Dichter \& Shapiro.

522) The hunting chorus. Baltimore: G. Willig Jr. [1829-67].

1 p. Piano solo. Attached to the back of The hunter's chorus.

The imprint of this piece has been changed to read Willig's.

Dating; Dichter \& Shapiro, 244.

523) I should very much like to know. Sung by Miss Clara Fisher. Composed by G.W. Reeve. Baltimore: Geo. Willig Jr. [1829-67].

2 pp. Voice w/piano acc.

Dating: Dichter \& Shapiro, 244.

524) I should very much like to know. Sung by Miss Clara Fisher. Composed by G.W. Reeve. Baltimore: Geo. Willig Jr. [1829-67]. 2nd copy.

2 pp. Voice w/piano acc. 
Dating: Dichter \& Shapiro, 244.

525) I turn to thee in time of need. Written \& adapted to a favourite Neapolitan melody by Thomas Haynes Bayly Esq. Baltimore: Geo. Willig Jr. [1829-67].

$2 \mathrm{pp}$. Voice w/piano acc.

Dating: Dichter \& Shapiro, 244.

526) Kinloch of kinloch. A favorite Scotch air. Arranged with Variations for the piano forte or harp. Baltimore: G. Willig Jr. [1829-67].

3 pp. Harp or piano solo.

Dating: Dichter \& Shapiro, 244.

527) Lassie let us stray together. A celebrated ballad as sung by Mr. Sinclair. Composed by B. Hime. Baltimore: Geo. Willig Jr. [1829-67].

$3 \mathrm{pp}$. Voice $\mathrm{w} / \mathrm{piano}$ acc.

Dating: Dichter \& Shapiro, 244.

528) Oh twine me a bower. Ballad. Written by Croston Croken Esq. Music by Alexr. D. Roche. Baltimore: Geo. Willig Jr. [1829-67].

2 pp. Voice w/piano acc.

Dating: Dichter \& Shapiro, 244.

529) Rise gentle moon. Ballad by J. Barnett. Baltimore: Geo. Willig Jr. [1829-67].

$2 \mathrm{pp}$. Voice $\mathrm{w} / \mathrm{piano}$ acc.

Dating: Dichter \& Shapiro, 244.

530) Teach, O! teach me to forget. Written by T.H. Bayly Esq. The music arranged by Henry R. Bishop. Baltimore: Geo. Willig Jr. [1829-67].

$2 \mathrm{pp}$. Voice $\mathrm{w} / \mathrm{piano}$ acc.

This print appears to have been a republishing of first verse and music of the publication by Dubois \& Stodart [1828-34].

Dating: Dichter \& Shapiro, 188, 244.

531) Two favorite pieces from the opera Der Freischutz. composed by Von Weber.

Baltimore: G. Willig Jr. [1829-67].

1 p. Recto is page 3 of "My sister dear". Voice w/piano acc.

Dating: Dichter \& Shapiro, 244; Krummel \& Sadie, 479 state that the firm was renamed George Willig Jr. in 1829.

532) Two favorite pieces from the opera Der Freischutz. Composed by Von Weber.

Baltimore: G. Willig Jr. [1829-67]. 2nd copy.

$1 \mathrm{p}$. Recto is page 3 of "My Sister dear". Voice w/piano acc.

Dating: Dichter \& Shapiro, 244; Krummel \& Sadie, 479 state that the firm was renamed George Willig Jr. in 1829.

533) Village band. Baltimore: Geo. Willig Jr. [1829-67].

1 p. Piano solo.

Dating: Dichter \& Shapiro, 244. 
534) We met! Ballad from the Songs of the Boudoir. Sung by Miss Paton. Words \& music by P.H. Bayly Esqr. Baltimore: Geo. Willig Jr. [1829-67].

3 pp. Voice w/piano acc.

Dating: Dichter \& Shapiro, 244.

535) Wi' my love I'll march away. Sung by Miss C. Fisher. Composed by G.A. Hodson. Baltimore: Geo. Willig Jr. [1829-67].

2 pp. Voice w/piano acc.

Dating: Dichter \& Shapiro, 244.

536) Woman's charms. A ballad. Sung by Mr. Horn. Composed by Alexr. Lee. Baltimore:

Geo. Willig Jr. [1829-67].

2 pp. Voice w/piano acc.

Dating: Dichter \& Shapiro, 244.

537) The little snow bird. The words by William Leggett Esqr. The music composed \& arranged for the piano forte and respectfully dedicated to Miss Oldmixon by I. T. Norton. Philadelphia: Geo. Willig [1830].

$3 \mathrm{pp}$. Voice w/piano acc.

On p. 1 below the imprint information: Entered according to Act of Congress the sixteenth day of August 1830 by Geo. Willig State of Penn.

Dating: Copyright notice.

538) The tri-colored quadrilles. Containing I see them on their winding way; Mi pizzica mi stimola; The Arab steed; Oft in the stilly night; French quadrille; Hail Columbia; The Marseliois March. With the figures as danced at the Military balls. New York: J.L. Hewitt [1830]. Uncataloged (Music book marked Harriet A. Stanton).

7 pp. Piano solo.

On foot of p. 2: Entered according to the Act of Congress, on the 27th day of November, 1830 by J.L. HEWITT of N.Y.

Lithograph of men and women dancing in a ball room. Marked "On Stone by Fleetwood." Hail Columbia is missing from this collection.

Dance steps are given after the first four and the last work.

Dating: Copyright notice.

539) Washington's birth day march and quick step. Composed \& arranged for the piano forte by Edward L. White, and dedicated to the W.L.J. Company, Newburyport. Boston: C. Bradlee [1830].

2 pp. Piano solo.

On bottom of p. 1: Entered according to Act of Congress the 2nd day of April 1830.

Dating: Copyright notice.

540) Watchman! tell us of the night, A missionary or Christmas hymn. By Bowring. Sung at the monthly concert, park St. church Boston. Music by Lowell Mason. Boston: C.

Bradlee [1830].

2 pp. 2 voices $w /$ piano acc.

On bottom of p. 1: (* Isaiah 21.11.) Entered according to Act of Congress, the 28th day of January 1830.

Dating: Copyright notice. 
541) My heart with love is beating. Arranged for the Spanish guitar. Philadelphia: John G. Klemm [1830?].

$1 \mathrm{p}$. Voice w/guitar acc.

Pub. no. 455.

Dating: Krummel, 182, supplement (based on pl. number).

542) Evening song of the Tyrol. Written by Mrs. Cornwell Baron Wilson. Composed by G.H. Rodwell. Philadelphia: E.R. Johnston \& Co. 6th ab: Chesnut St. [ca. 1830].

$2 \mathrm{pp}$. Voice $\mathrm{w} /$ piano acc.

Stamped J. Marsh music store Wilmington Del. In 1832 Marsh was located in Wilmington (Dichter \& Shapiro, 213).

Dating: Dichter \& Shapiro, 213. Johnston \& Co. is not listed in Dichter \& Shapiro.

543) Fantasie for the flute and piano forte, obligato. Respectfully dedicated to his pupils Wm. and Emma Meredith by John H. Hewitt. Baltimore: G. Willig Jr. [ca. 1830]. $8 \mathrm{pp}$. Flute w/piano acc.

Dating: Dichter \& Shapiro, 205, based on activity of James L. Hewitt who published works by John H. Hewitt.

544) Ode to Washington. Suitable to be sung on the 22nd of February (Washington's birth day.) n.p. [Boston?, ca. 1830]].

$1 \mathrm{p}$. Voice w/piano acc., and chorus. At the top of the page: Desirous of perpetuating the memory of Washington, I wrote this music from memory, of an Ode sung Mr. Thatcher (crossed out in ink to read D Rhea), October 26 1789; on the occasion of President Washingtons arrival at the Old State House, Boston. Having learned it from my Father in 1805 , when ten years of age, he being one of the chorus singers. Benjamin B. Davis. Dating: based on the age of the composer, Benjamin B. Davis.

545) Favorite Swiss Waltz. With variations for the piano forte by P.K. Moran. New York: James L. Hewitt \& Co. [1830-31].

5 pp. Piano solo. Composed by Peter K. Moran.

Dating: Dichter \& Shapiro, 205.

546) Mama, Mamma or why dont the men propose. Ballad. The poetry by T. Haynes Bayly Esq. The music composed by J. Blewitt. New York: James L. Hewitt \& Co. [183031].

$3 \mathrm{pp}$. Voice $\mathrm{w} / \mathrm{piano}$ acc.

Dating: Dichter \& Shapiro, 205.

547) Norah the bride of Kildere. Sung with rapturous applause by $\mathrm{Mr}$. C. Horn. The melody by John Parry. Adapted \& arranged by Charles E. Horn. New York: James L. Hewitt [1830-31].

3 pp. Voice w/piano acc.

Dating; Dichter \& Shapiro, 205.

548) Oh peaceful lake! Lines written on The Lake of Windermere. By Thomas Blake and inscribed to Mrs. F. G. Loder (of Bath). The music composed by Bianchi Taylor. New York: James L. Hewitt [1830-31]. Uncataloged (Music book marked Harriet A. Stanton). 6 pp. Voice w/piano acc.

Lithograph of lake and surroundings signed: Pendleton's Lithography Boston. 
Dating: Dichter \& Shapiro, 205.

549) The soldiers tear. Sung by Miss Watson at the theatres \& public concerts. The words by Thos. Haynes Bayly Esq. Arranged by Alexander Lee. New York: James L. Hewitt \& Co. [1830-31].

3 pp. Voice $w /$ piano acc.

Cues for trombo and corni on p. 1.

Dating: Dichter \& Shapiro, 205.

550) Love's ritornella. The much admired Air. As sung by Mr. Simpson in the popular drama of the Brigand. New York: E.S. Mesier [1830-34].

$2 \mathrm{pp}$. Voice $\mathrm{w} / \mathrm{piano}$ acc.

Lithograph of Massaroni (Mr. Simpson) singing to Maria (Mrs. Sharpe), Odell, vol. 3, 456-7.

Dating: Odell, vol. 3, 456 identifies date of the Brigand (1830); Dichter \& Shapiro, 214.

551) Saw Ye Aught of my Love, Sung by Miss P.Horton, In the Scotch Ballad Opera The Covenanters composed by Edward J. Loder. New York: James L. Hewitt \& Co. [183035].

$3 \mathrm{pp}$. Voice w/piano.

Stamp: Sold by G. Willig 171 Chestnut. More than a three-quarters of the page is the title.

Dating Dichter \& Shapiro, p. 205. 


\section{INDEX OF TITLES}

Absence. 174

Adams and liberty. 12

Adieu my native land adieu. 147

Ah! vous dirai, je maman. 84 ,

Ah, what is the bosom's commotion. $43,44,50$

Alice Gray. 440, 441, 514

All's well. 325

All that's bright must fade. 209

All the blue bonnets are over the border. 470

The American Musical Miscellany. 9

The American patriotic song book. 72

Andantino and The waving willow. 61

And canst thou think. 236, 246

Annot Lyle! 476, 515

The apparation of a dandy. 211

The Arab maid. 385

The Arab steed. 501

Araby's daughter. From Lalla Rookh. 270, 306, 361

Aria alla scozzese con variazione. 206, 388

Auld lang syne. 168

Auld Robin Gray. 151, 152

Awake the note of war. 269

Away away to the mountains brow. 326

Ye banks and braes of bonny doon. 99

The banks of Allan water. 181, 442

The battle of Prague. 451, 513

The battle of Trenton. A sonata for piano forte. 6

Battle of Waterloo. 327

The beautiful maid. 92, 93

The beggar girl. 30

Be mine dear maid. 100

Be mine tender passion! 132

Believe me if all those endearing young charms. 204

The bird waltz. 212, 443

Blossom loveliest flower. 13

The blue bell of Scotland. 27

Blue eye'd Mary. 101, 389

Bochsa's celebrated march. 477

The bonnie bark. 328

Bonnie doon. 511 
Boston independent cadets' grand march. 456

Bounding billows. 313

The braes o' Balquhither. 182, 303

Brazilian waltz. 64

The bridemaids song \& chorus in the melo drame of Der Freischutz. 283

Bring flowers. 5 i 6

Bruce's address to his army. 153

Burlington arcade, A favorite air in Tom and Jerry. 284

"Buy Image!" 444

Cadet's march. 105, 314

A Canadian boat song. 87

The captive knight. 517

A captive once said to a linnet. 178

The carnival of Venice. 329

The carrier pigeon. 244

A catalogue of music. 197

The celebrated dance in Tekeli. 79

The celebrated hanseatic quickstep march. 285

The celebrated overture to La Dame Blanche. 330

C'est l'amour. 478

The champion of freedom. 247

The chaplet. 508

Charlie is my darling. 189

The cheat. 425

Cheer up! Pull away. 213

Cherry ripe. 286

La ci darem la mano! 163

A collection of popular airs arranged as cottilions. 331, 332, 333

College hornpipe and Fishers hornpipe. 77

Come, dearest at ev'ning hour. 479

Come rest in this bosom! 176, 315

Come take the harp. 55

The comet with variations for the piano forte. 304

Comin' thro the rye. 362

The Copenhagen waltz. 106

The coronach. 53

The corsair's farewell. 334

The cottage rondo. 107, 108, 391

Crazy Emma. 14

The cuckoo. 109

Curly locks and Little bo peep from Twelve little ballads and a favorite lesson. 169 The cypress wreath. From Rokeby. 74 
Dainty Davie. 146

The dark eyed one. 335

The dashing white sergeant. 300

The day of marriage. 48

Dead march \& monody. 18

Dearest sweetest bonny lassie! 172, 316

Decatur's victory. 69

Di tanti palpiti. 336

Divertisement for the piano forte. 317

Do I do I don't do nothing. Negro song. 273

The downfall of Paris. 392

A duett for two performers on one piano forte. 160, 161

The Duke of York's march. 133

The Duke of York's troop and 2 waltz's. 71

Dulce domum. 56, 59

Ellen of Lismore. 337

Emblems of mem'ry are these tears. 15

Emperor Alexander's waltz. 248

Even as the sun with purple colour'd face. 338

Evening song of the Tyrol. 542

Evening song of the Tyrolese peasants. 457

The fall of Paris. 62, 363, 481

Fantasie for the flute and piano forte. 543

Far far from me my lover flies. 45

Far, far o'er hill and dell. 287

The farewell. 46

Farewell Bessy. 36

Farewell but whenever you welcome the hour. 198

Farewell since we must part. 393

The favorite air or $\mathrm{O}$ dolce concento. 512

The favorite dance in the grand pantomime of The Forty Thieves. 51

The favorite German serenading waltz. 134, 135

The favorite new federal song. 10

The favorite pastoral in the Coronation of Henry the 5th. 339

Favorite pieces from the opera Der Freischutz. 340

The favorite Scotch air Auld langsyne. 115, 125

Favorite Swiss waltz. 110, 341, 545

The favorite Vienna waltz. 126

A favorite waltz. Composed by M.A. Mozart. 102, 183

The favourite Bath waltz. 288

A favourite selection of music. 39

Feast of roses. 394 
Flow on thous shining river. 116

Fly to the desert. From Lalla Rookh. 121

Follow, follow thro' the sea. 274, 318

For me let fall a tear! 518

Fra tante angoscie. 429

The freemason's library and general Ahiman Rezon. 94

Fresh and strong the breeze is blowing. The favorite song in Inkle \& Yarico. 148

From flowers which we twine for the temples of love. 237

From Greenland's icy mountains. 364

Funeral dirge on the death of General Washington. 19

A funeral elegy on the death of General George Washington. 20

Gaily the troubadour touch'd his guitar. 480, 519

La gaite. 365

The gallant troubadour. 136,395

The gathering of the clans. 214

General Washington's march. 33

Go George I cant endure you. 396

Go my love. 275

Grand Austerlitz march. 305

The grand canal celebration, ball. 276

Grand march for the piano forte. 249

A grand Russian march. 458

Green hills of Tyrol. 445

Hail Columbia! 215

Hail to the happy day. 162

Hark from the tombs, and Beneath the honors. 22

Hark! hark! through the wild wood. 384

The harp, or selected melodies from authors eminent for genius and taste. 95

Haydn's andante. The surprise. 250

The heart of a woman. 266

Her heart is not there. 482

Herr Cline's dance. 342

Hey the bonnie breast-knots. 307

The highland bride. 397

A highland laddie hear of war. 196

The highlanders chorus. 398

Home arranged for the Spanish guitar. 308

Home! Sweet home! 216, 265, 366, 399, 483

Hornpipe. 63

Hours there were. 289

How oft when watching stars. 238

Hull's victory. 70 
Hummel's celebrated waltz. 177, 301

The Hungarian waltz. 127, 157

Hunter of Tyrol. 484

The hunter's chorus from Der Freychutz. 521

The hunter's signal horn. 367

The hunting chorus. 343, 522

The hunting chorus from Der Freyschutz. 459, 521

Hurrah for the bonnets of blue. 309,520

I am wearing awa' to the land o' the leal. 187

I have a heart. 47

I've been roaming. 400

I left thee where I found thee love! 205

I lo'e nae a laddie but ane. 369

I saw from the beach. 344

I should very much like to know. 523, 524

I turn to thee in time of need. 525

I was a wild and wayard boy. 90

I won't be a nun. 252

I'd be a butterfly. 471

I'd be a dove. 368

I'll love thee ever dearly. 111

I'll pull a bunch of buds and flowers. 277

I'll watch for thee from my lonely bow'r. 290, 319, 370

In happier hours "Melodies of various nations." 485

The invincibles. 371

The invitation. 401

Isabel. A celebrated Spanish serenade. 251

The Jager chorus from Weber's celebrated opera Der Freischutz. 324

Jessie the flow'r o' Dumblane. 81

Jesu saviour of my soul. 35

Le jeu d'esprit. 217

John Anderson my Jo. 452

Le joujou. 430

Kate Kearney. 431, 432,

Kinlock of kinlock. 372, 526

Kitty clover. 403

The knight errant. 128

La Fayette's grand march. 446

To ladies eyes. 199

The lass wi the bonny blue E'en. 486

Lassie let us stray together. 527

The last link is broken. 345 
Latour's favorite waltz. 96

Latour's overture No. 1. 179

Latour's overture No. 2. 180

The lavender girl. 373

The lee rigg. 218,426

Let this brow on thy bosom reclining. 175

Let truth and spotless faith be thine. 25

Let us haste to Kelvin grove. 267, 268, 291

Let Washington be our boast. 21

Life let̂ us cherish. 310

The light bark. 346

The light guitar. 433

The lighthouse. 154

Like the gloom of night retiring. 155, 156

Listen dear Fanny. 347

The little snow bird. 537

Little Winny Wilkins. 54

Look out upon the stars my love. 219, 234

Louden's bonny woods and braes! 137

Love among the roses. 82

Love and time. 190

Love has been there. 460

Love thee dearest. 302

Love was once a little boy. 374

Love's ritornella. 487,550

Love's young dream. 65

Lucy or Selim's complaint. 4

Lullaby. Arranged as a rondo for the piano forte. 220

Mad. de Nouville's waltz. 253

Maid of Athens. 245

The Maltese boatman's song. 404

Mama, Mamma or why dont the men propose. 546

March \& chorus in the dramatic romance of The Lady of the Lake. 221

March from Masaniello. 488

March in Henry the Fourth. 170

March in the battle of Prague. 427

March in the melodrama of Der Freyschutz. 292

March to the battle field. 375, 376

The Marseilles hymn. 405

Mary, the maid of the green! 129

Mary's dream or Sandy's ghost. 406

Meet me by moonlight. 377 
The Mexican waltz. 407

The midshipman. 293

Mild as the moonbeams. 461

Military rondo for the piano forte. 489

The minute gun at sea. $88,89,142$

The minstrel's harp. 66

The minstrel's return'd from the war. 320

Miss Dennett's waltz. 222

Money musk. 348

Moran's favourite variations to the Suabian air. 408

Moravian waltz. 294

The morning star. 130

Moss roses. 434

The mountain maid. 409

Mrs. Poe. 254

A much admired duett for two performers on one piano forte. 223

The musical journal for the piano forte. 24

The musical magazine. 31

My ain kind dearie. 200

My heart and lute. 271, 295

My heart with love is beating. 541

My heart's in the highlands. 255

My Henry is gone. 210

My love's the fairest creature or Shelah na Conolan. 184

My mother bids me bind my hair. 138

My sweet my blue eyed Mary. 462

National guards march and rondo for the piano forte. 490

National melodies, consisting of the most admired airs of England, Ireland, Scotland and

Wales. 158

Neapolitan dance. 506

Ne'er can the rose from the comic opera of the Marriage of Figaro. 224

Negro dance; the coquette; the colly flower. 410

A new arrangement of the overture to the Caliph of Bagdad. 472

The new presidents march. 3

New Yankee Doodle. 11

The New York admired cotillions. 235

The nightengale. 37

Nobody. 8

Norah the bride of Kildere. 547

Now at moonlight's fairy hour. 57

O hie thee home will. 49

$O$ innnocence celestial maid. 7 
O my love's like a red rose. 149

$O$ never fall in love. 378

O sing sweet bird or the captive to his linnet. 42

O swiftly glides the bonny boat. 188, 239

$\mathrm{O}^{\prime}$ they marchd thro' the town. 492

Ode to Washington. 463,544

Of a' the airs. 225

Oh! come my love along the sea. 498

Oh ever in my bosom live. 32

Oh give me but my Arab steed. 507

Oh 'tis love adapted from the French air, C'est l'amour. 258

Oh 'tis love sung by Mr. Pearman in I will have a wife. 257

Oh lady ne'er think I'll prove false to thee. 278

Oh Nanny wilt thou gang with me. 131

Oh never fall in love. 464

Oh! no I'll never mention him. 386

Oh! no we never mention her. 491

Oh peaceful lake! 548

Oh! remember the time. 139

Oh! say not woman's heart is bought. 164

Oh! say not woman's love is bought. 193

Oh tell me how from love to fly. 165,173

Oh twine me a bower. 528

Oh, what a row! or The adventures of a steam packet. 191

On younder rock reclining. 411

The origin of the harp. 323

The overture to the favorite opera Der Freyschutz. 435

Overture to the opera of The Two Blind Men of Toledo. 226

Par sa legéreté. 5

Parisian rondo. 321

La Parisienne. 473

The parting pledge. 140

Pensez a moi sa chere amie. 412

Le petit tambour. 322, 349

The pilgrim fathers. 453,454

The pirate lover. 259

The plain gold ring. 260,379

The plough boy. 159

Polish march. 350

Poor old maids. 240

The popular air Eveleen's bower. 117

A popular Swiss air. 474 
The Portuguese hymn. 41

The President's march. 2, 143

A prey to tender anguish. 113

Prince Kutusoff, a much admmired dance arranged as a rondo for the piano forte. 228

Purcell's ground. 228

Quatre petits morceaux; March de Moise. 351

The Queen of Prussia's and the Russian waltz. 114

The rejected lover. 206

Rest, weary traveller. 185,186

La retour de Wicklow. 118

Le retour de Kips hill. 202

Return O my love. 436

The Revolutionary soldier's lullaby. 201

Richmond's march. For the piano forte. 123

Riego's celebrated quick step. 241

Rise gentle moon. 529

The rose-bud of summer. 103

The rose of Allandale. 493

Rose of Lucerne. Or the Swiss toy girl. 380, 381

Rudiments of the art of playing on the piano forte. 40

Run Jerry run. 296, 447

Russian march, and the emperor Alexanders waltz. 229

Sacred dirges, hymns, and anthems. 23

St. Patrick's day, arranged as a rondo for the harp or piano forte. 230

Sandy and Jenny. 413

Say my heart why wildly beating. 279

Saw ye aught of my love. 551

Saxon air! Introduction and variations for the piano forte. 122

Say ye my wee love. 261 ,

A selection of the most admired ballads, taken from the newest comic operas and Vauxhall entertainments. 26

La serenade. 465

The shawl dance. 60

She's gone! A daughter's gone to save. Recitative and pollacca. 67

She is thine. 414

Ship a hoy! 499

Sicilian air on which is found the popular ballad of Home! sweet home. 272

Sicilian dance. 80

Silent glances. 242

Silent oh Moyle! 503

Since then I'm doom'd. 171

The sisters. 415 
Slowly wears the day, love. 262

Smile again my bonnie lassie. 311

Snowy rose go deck my fair. 52

Une soiree du vaudeville. 494

Soldier rest, the fight is over. 231

The soldier's bride. 352

A soldier's gratitude. 97

The soldier's grave. 382

The soldier's joy; Miss McLeod's reel; Tho 'tis all but a dream; My heart and lute. 428

The soldier's tear. 353,549

A soldier's the lad I adore. 466

Song to the memory of Mozart. 91

Sound the loud timbrel. 98

The sprig of Shillelah. 354

The spring time is come. 448

Stantz waltz. 104, 263

Star spangled banner. 86, 504

The stop waltz. 355

The storm rondo for the piano forte. 119

Strike the cymbal. 124, 203

Sul margine dun rio. 232

The sun that lights the roses! 167

Sweet lillies of the valley. 1

Sweetly in life's jocund morning. 29

The Swiss boy. 416,437

The Swiss girl. 387

Take this rose. 120

Teach, O! teach me to forget. 530

A temple to friendship. 207, 208

They're a' noddin. 281

Theres a tear that flows when we part. 312

There's nothing true but heaven. 500, 502

Tho 'tis all but a dream. 297

Three duettos. For juvenile performers on the piano forte. 356

The timid tear. 38

'Tis not his form, so fair to view. 233

'Tis the last rose of summer. 112

Titus march. 280

Tivolian waltz. 357

Today, dearest is ours. 438

Too late I staid. 73

The tooth ache. 417 
Treasures of the deep. 418

The tri-colored quadrilles. 538

'Twas in the sultry noon-tide hour. 16

'Twas within a mile of Edinburgh. 402

Twelve little ballads and a favorite lesson. 58

Twilight dews. 419,467

Two favorite pieces from the opera Der Freischutz. 531, 532

Tyrant! soon I'll burst thy chains. 282

The Tyrolese song of liberty. 85

United States marine march. 298

The vail, or Stranger think me not too bold. 28

Valse du Turc in Italie. 495

Variations for the piano forte on a favorite dance The soldiers joy. 455

Variations on Moore's favorite melody Beleive [!] me if all thos \&c. 420

A Venetian air. 150

Village band. 533

The vintager's evening hymn. 449

Von Weber's last waltz. 421

The wandering harper. 468,469

Wandering Willie or here awa there awa. 422

The washing day. 194

Washington's birth day march and quick step 539

Washington's favourite the brave La Fayette. 243

Washington's march. 68, 144

The watchman. 509

Watchman! tell us of the night. 540

The waterman. 145

Waters of Elle. 264

A weary lot is thine fair maid! From Rokeby. 75

We met! 358, 450, 534

We're a noddin at our house at home. 192

Wery pekooliar, or the lisping lover. 505

Wha'll be king but Charlie. 383

When death's gloomy angel was bending his bow. 78

When I was a girl of eighteen years old. 423

When morning like a blushing bride. 475

When you're roaming. 496

Where is my lover? 299

Where roses wild were blowing. 141, 439

Where, where is the rover. 359

The white cockade. 497

White's favourite airs. 424 
Will you come to the bow'r. 76

Wilt thou meet me there love. 510

Wi' me love I'll march away. 535

The wish. 34

Woman's charms. 536

The wounded hussar. 17

Wreaths for the chieftain. 83

Yankee doodle. Arranged with variations for the piano forte. 195

La zelmire. 360 


\section{INDEX OF COMPOSERS AND ARRANGERS}

Anderson, G. 327

Andrews, T. 39

Arkwright, Robert Mrs. 418

Arne, Thomas. 94, 461

Arnold, Samuel. 39, 148

Attwood, Thomas. 26

Auber. 335, 473

Avison, Charles. 98

Aykroyd, J. 259

Barnett, John. 368, 380, 381, 397, 433, 434, 529

Bayly, Thomas Haynes. 358, 450, 471, 480, 519, 534

Beethoven. 188

Bennison, T. 118

Berry, Agustus. 38

Bishop, Henry R. 97, 155, 156, 196, 216, 224, 233, 237, 238, 251, 274, 275, 282, 297, $300,366,428,483,485,491,530$

Blake, George E. 58

Bland, John. 26.

Blewitt, J. 505, 546

Bochsa, Robert Nicholas Charles. 262, 477

Bohlius, J. F. 113

Boieldieu, A. 330, 472

Braham, John. 52, 56, 58, 92, 93, 185, 186, 244

Bray, John. 74

Browne, Miss. 454, 517

Burrowes, J. F. 512

Cardon, fils. 84

Carr, Benjamin. 18, 24, 39, 323, 468, 469

Carr, Thomas. 422

Carter, Charles Thomas. 131

Challoner, Neville Butler. 222

Chaulieu. 488

Cherry. 54

Clarke, John. 53, 66

Clifton, Arthur (assumed name of Philip Anthony Corri). 165, 173, 206, 211, 231, 241, 269,

Clifton, William 345

Cole, Samuel. 94

Cooke, Thomas Simpson. 111, 230, 487

Coppock, W. R. 446 
Corri, Domenico. 200, 426

Corri, Haydn. 383

Costellow, Thomas. 80

Cramer, J. B. 122, 158

Craven, J. T. 346

Cubbert, T. E. 464

Darley, W. H. W. 312

Davies, John. 172, 182, 242

Davis, Benjamin B. 544

Davy, John. 100, 149, 266

Devereaux, L. 404

Diabelli, Anton. 435

Doyle, John Colston. 82

Dressler, Rafael. 215

Dussek, Jan Ladislav. 159, 294

Eckhard, J. Jr. 76

Elfort. 39

Emrick, George. 401

Fiorelli, M. 506

Fiorini, G. E. 250, 363

Flottes, A. 494

Gauline, J. B. 14

Geib, Adam. 27

Gelineck, Joseph. 177, 301, 304

Gildon, J. 356

Gilfert, Charles. 73, 75, 205, 436

Gilles, Henri-Noel. 219, 234, 431

Graupner, Gottlieb. 31, 40

Gray, G. 47.

Grosse, W. 429

Gubert, T. E. 465

Guylot, Robert. 518

Hagen, Peter Albrecht von. 19

Hance, James F. 239, 305, 362

Hansen, E. R. 314

Hargreaves, George. 430

Harrington. 58

Harris, George Frederick. 324

Harris, Rev. T. M. 23

Haydn, Joseph. 24, 46, 113, 138, 250

Haynes, Thomas. 525

Heather, W. E. 39 
Heber, Bishop. 364

Henkel, Michael. 226

Hewitt, James. 6, 17, 24, 184

Hewitt, John Hill. 320, 466, 543

Hime, B. 527

Hodgkinson, John. 11, 21

Hodson, G. A. 385, 476, 482, 501, 507, 515, 535

Holden, T. L. 106

Holst, Matthias von. 79, 107, 108, 349, 391

Holyoke, Samuel. 22

Hook, James. 1, 4, 26, 39, 79

Hooton, James. 455

Hopkinson, J. 10

Horn, Charles E. 181, 286, 338, 400, 442, 463, 496

Hortencia, Queen of Holland. 128

Houston, J. G. 412

Hummel, Johann Nepomuk. 177, 301

Hünten, Franz. 415

Hutton, Joseph. 70.

Incho, William. 479

Jackson. 39

Jordan, Dorothea Bland. 27

Katurla, A. F. Huerta y. 241

Keene, S. 347

Kelly, Michael. 24, 39, 44, 50, 51, 58, 190

Kiallmark, George. 90, 121, 245, 270, 361

King, Matthew P. 45, 88, 89, 142

Klemm, John G. 249

Knight, Edward, Jr. 299, 475

Koczwara, Franz. 427, 451, 513

Kozeluch, Leopold. 146, 452

Kuffner, J. 456

Kuhlau, F. 365

Labarre, T. 414

Latour, T. 96, 171, 179, 180, 217, 223, 232, 317

Lee, Alexander. 326, 353, 359, 367, 378, 384, 520, 536, 549

Lee, Bernard. 322

Lemoine, Henry. 351, 495

Lhulier, J. 498

Ling, William. 99

Linley, George. 334

Loder, Edward J. 551 
Logier, J. B. 117

Maddison, G. 444

Mann, Henry. 39

Martin, William. 202

Mason, Lowell. 540

Mayseder. 322

Mazzinghi, Joseph. 29, 42, 67

Mehul, Etienne Nicolas. 226

Meignen, L. 503

Meineke, C. 247, 407

Millard, P. Mrs. 440, 441, 514

Monro, John 129

Moore, Thomas. 38, 428

Moorehead, I. 28

Moran, Peter K. 104, 110, 137, 147, 150, 160, 161, 244, 263, 341, 408, 461, 490, 499, 545

Moscheles, Ignaz. 387, 416, 437, 481

Moulds. 95

Mozart, Wolfgang Amadeus. 25, 58, 91, 102, 163, 183, 310, 512

Naegeli. 95

Nash, W. 448

Nelson, S. 449, 484, 492, 493

Nicholson, Charles. 512

Nicks. 26

Norami, Pietro. 194

Norton, I. T. 457, 537

Osbourn, James G. 393, 398, 417

Panormo, Francis C. 114, 212, 443

Parish, Edward. 227

Parry, John. 140, 281, 311, 328, 369, 547

Peale, B. Franklin. 306, 307, 308, 309, 460, 467, 468, 469

Pelissier. 63

Phile, Philip. 215

Philipps, T. 337

Phillips, C. E. 175

Piercy, H. 30

Pleyel, Ignace. 24.

Pucitta, Vincenzo. 124, 203

Reeve, George W. 32, 39, 256, 257, 258, 523, 524

Reinagle, Alexander. 26, 58,

Relfe. 95

Robertson, Alexander. 261 
Robinson, Mrs. 58, 313

Roche, Alexander D. 528

Rodwell, George H. 542

Rosenberg, S. T. 477

Ross, Daniel 115, 125

Ross, John. 187

Rossini, Gioachino. 162, 429, 445

Rovedino, T. 445

Rycott, J. M. 371

Sanderson, James. 26, 49, 83, 221

Sargent, L. M. 83

Schmitz, A. 509, 510

Schroeder, R. 474

Schulz. 13

Shaw, Oliver. 39, 500, 502

Shield, William. 39, 58, 61, 293

Sim, John. 267

Simpson, Thomas 230

Sinclair, John. 278, 486

Smart. 95

Smith, Henry F. 141

Smith, J. S. 94

Smith, R. A. 95, 267, 268, 291

Smith, Robert Archibald. 268

Sola, Charles Michel Alexis. 236, 246, 287

Soler, Vincente Martin y [Martini]. 274, 318

Steibelt, Daniel. 119, 220, 321, 339

Stevenson, John Andrew. 55, 65, 95, 103, 112, 116, 198, 199, 204, 207, 208, 209, 210 , $289,290,319,344,370$

Storace, Stephen. 39, 132, 201, 220,

Strickland, W. 69

Tannahill, R. 81

Tanner, John $376,377,386$

Taylor, Bianchi. 548

Taylor, Raynor. 2, 8, 68, 78

Thompson, D. 91

Thompson, Thomas. 34, 57

Trajetta, Filippo. 24.

Valentine, Thomas. 272, 388, 420, 478, 497

Viguerie, B. 489

Viotti, Giovanni Battista. 302

Wade, Joseph A. 289 
Weber, Carl Maria von. 260, 279, 283, 292, 340, 379, 421, 435, 459, 521, 522, 531, 532 Weldon, Peter. 64

Whitaker, John. 54, 164, 193

White, Edward L. 539

Wiesenthal, Thomas Van Dyke. 120, 213

Williams, R. L. 276

Williams, Thomas. $166,167,382$

Willig, George. 169

Willis, Richard. 312

Wilson, Joseph. 154

Wood, Abraham. 20

Zampieri. 24 


\section{INDEX OF PUBLISHERS BY CITY}

\section{BALTIMORE}

Carr, Joseph, Baltimore. 4, 7, 18, 24, 28, 34, 42, 65

Carr, Thomas, Baltimore. 162, 173

Cole, John, Baltimore. 188, 234, 243, 247, 251, 290, 298, 299, 432, 505

Edes, Benjamin, Baltimore. 94

Willig, George, Baltimore. 203, 218, 219, 240, 241, 254, 260, 262, 273, 280, 301, 302, $303,304,425,426,427,428,504$

Willig, Jr., George. Baltimore. 431, 466, 514, 515, 516, 517, 518, 519, 520, 521, 522, $523,524,525,526,527,528,529,530,531,532,533,534,535,536,543$

\section{BOSTON}

Ashton, John. Boston. 384

Bradlee, C., Boston. 451, 452, 453, 454, 455, 456, 539, 540

Graupner, Gottlieb, Boston. 31, 32, 33, 40, 61, 83, 114, 175, 266

Hagen, Peter Albrecht von, Boston. 19

Hewitt, James L., Boston. 42, 305, 324

Hewitt, James L. \& Co., Boston. 250,

Jackson, E. W., Boston. 184, 187

Mallet, F., Boston. 42

Thomas, Isaiah \& Andrews, Ebenezer T., Boston. 20, 23

DEDHAM, MASSACUSETTS

Mann, Herman, Dedham, Massachusetts. 39

EXETER, NEW HAMPSHIRE

Ranlet, H., Exeter. 22

\section{GREENFIELD, MASSACHUSETTS}

Denio \& Phelps, Greenfield, Massachusetts. 95

\section{NEW YORK}

Bourne, New York. 440, 441, 442, 443, 444, 445, 446, 447, 448, 449, 450

Carr, Benjamin, Philadelphia and New York. 7

Dubois, William, New York. 92, 93, 96, 97, 98, 105, 106, 107, 108, 109, 110, 112, 113 , $115,116,117,118,119,134,135,137,138,141,148,149,150,160,161,163$, $164,166,167,172,176,177,179,180,207,208,238,239$,

Dubois \& Stodart, New York. 181, 182, 183, 189, 190, 192, 197, 205, 274, 275, 278, $279,282,317,429,430,433,434,435,437,438,461,463,473,474,475,476$, $477,478,479,480,481,482,483,484,485,486,487,488,489,490,491,492$, $493,494,495,496,497,499$ 
Firth \& Hall, New York. 235, 322, 360, 507

Fleetwood, A., New York. 471

Geib \& Co., New York. 101

Geib \& Walker, New York. 511, 512, 513

Geib, Adam and William, New York. 202

Geib, John, Adam and William, New York. 129, 132, 133, 136, 139, 140

Gilfert, Charles, New York. 12

Hewitt, James, New York. 6, 11, 21, 24, 27, 28, 49, 51

Hewitt, James L. New York. 538, 547, 548

Hewitt, James L. \& Co., New York. 545, 546, 549, 551

Meetz, R., New York. 159

Mesier, Edward S., New York. 361, 362, 363, 364, 365, 366, 367, 368, 369, 370, 371, $372,373,374,375,376,377,378,379,380,381,382,383,385,386,387,444$, 550

Paff, John \& Michael, New York. 36, 45, 77

Riley, Edward, New York. 64, 71, 73, 123, 124, 127, 130, 142, 143, 144, 145, 147, 191, $198,199,200,201,223,242,245,248,256,257,258,263,276,325,326,327$, $328,329,330,331,332,333,334,335,336337,338,339,340,341,342,343$, $344,345,346,347,348,349,350,351,352,353,354,355,356,357,358,359$, $436,458,459,472,506$

Willson, Joseph, New York. 62

NORFOLK, VIRGINIA

Balls, G., Norfolk. 158

NORTHAMPTON, MASSACHUSETTS

Wright, Andrew, Northampton, Massachusetts. 9.

\section{PHILADELPHIA}

Aitken, John, Philadelphia. 48

Bacon, Allyn, Philadelphia. 99

Bacon, Allyn \& Co., Philadelphia. 86, 102, 120

Bacon, Allyn \& Valotte \& Lété, Philadelphia. 104

Bacon, George, Philadelphia. 216

Balls, G., Philadelphia. 103

Blake, George E., Philadelphia. 38, 42, 43, 44, 46, 47, 52, 55, 56, 57, 58, 66, 67, 69, 74, $75,76,79,80,82,84,128,131,146,152,157,159,171,174,185,186,246$, $259,265,300,306,307,308,309$

Carr \& Co., Philadelphia. 1.

Carr, Benjamin, Philadelphia. 3, 4, 8, 10, 29, 30,

Carr, Benjamin, Philadelphia and New York. 7

Carr, Benjamin \& Schetky, John George, Philadelphia. 35, 41, 42 
Chalk, John, Philadelphia. 24

DeSilver, Thomas, Philadelphia. 81

Hobson, R. H., Philadelphia. 508, 509, 510

Johnston, E. R. \& Co., Philadelphia. 542

Klemm, Johann Gottlob, Philadelphia. 212, 213, 215, 217, 220, 221, 222, 227, 228, 230 , $233,249,252,253,255,264,281,283,284,285,286,287,289,291,292,293$, 294, 295, 296, 297, 310, 311, 313, 314, 315, 316, 318, 319, 321, 439, 470, 501, 503,541

M'Culloch, W., Philadelphia. 72

Morgan, John, Philadelphia. 26

Priest, William, Philadelphia. 2.

Shaw, R., Philadelphia. 28

Trisobio, Filippo, Philadelphia. 5.

Willig, George, Philadelphia. 13, 14, 15, 16, 17, 25, 50, 53, 54, 59, 60, 63, 68, 70, 78, 85, $87,88,89,90,91,100,111,121,122,125,126,151,153,154,155,156,165$, $168,169,170,178,193,194,195,196,206,209,210,211,214,224,225,226$, $229,231,232,236,237,261,267,268,269,270,271,272,312,320,323,388$, $389,390,391,392,393,394,395,396,397,398,399,400,401,402,403,404$, $405,406,407,408,409,410,411,412,413,414,415,416,417,418,419,420$, $421,422,423,424,457,460,462,464,465,467,468,469,498,537$

Willig, Jr., George. Philadelphia. 204

PORTSMOUTH, NEW HAMPSHIRE

Treadwell, William and Daniel, Portsmouth. 37

PROVIDENCE, RHODE ISLAND

Shaw, Oliver; Providence, Rhode Island. 500

WASHINGTON, D.C.

Thompson, Pishey, Washington, D.C. 508

No publisher given. $244,277,288,296,502,544$ 


\section{INDEX OF PERFORMANCE MEDIA}

Clarinet with piano accompaniment. 64

Flagiolet with piano accompaniment. 64

Flute with piano accompaniment. 24, 215, 232, 314, 317, 322, 430, 459, 472, 512, 543

Four-part chorus. 20, 22, 239

Four-part chorus with piano accompaniment. 9, 22, 203, 327, 463

Guitar solo. 398, 424

Harp solo. 60, 62, 84, 110, 150, 212, 230, 443, 526

Melody arranged for clarinet. 10

Melody arranged for flageolet. 103

Melody arranged for flute. $10,11,17,86,103$

Melody arranged for guitar. 1, 4, 10, 17, 28

Melody arranged for two clarinets. 18

Melody arranged for two flutes. 18

Melody arranged for two guitars. 18

Melody arranged for two violins. 18

Melody arranged for violin. 10

Piano four hands. 2, 160, 161, 223, 226, 324, 329, 336, 349, 356, 415

Piano solo. 3, 6, 18, 24, 27, 31, 33, 39, 40, 51, 58, 60, 62, 63, 68, 71, 76, 77, 79, 80, 84, $96,99,101,102,104,105,106,107,108,110,114,117,118,119,122,123$, $126,127,130,133,134,135,143,144,145,150,157,158,159,170,171,177$, $179,180,195,200,202,212,217,218,220,222,227,228,229,230,235,241$, $248,249,250,253,263,272,276,280,285,288,292,294,298,301,304,305$, $321,327,330,331,332,333,339,340,341,342,343,348,350,351,354,355$, $357,360,363,365,388,392,407,408,410,417,420,421,425,426,427,428$, $429,432,435, .443,446,451,455,456,463,472,473,474,477,478,481,488$, $489,490,494,495,497,506,508,513,521,522,526,533,538,539,545$

Three-part chorus. 22, 23, 94

Three-part chorus with piano accompaniment. 9, 22, 41, 87, 98, 124, 221, 404, 449

Two-part chorus. 18, 37, 94

Two-part chorus with harp accompaniment. 57

Two-part chorus with instrumental bass accompaniment. 31

Two-part chorus with piano accompaniment. 9, 19, 32, 57, 88, 137, 142, 163, 185, 186, $325,345,540$

Violin with piano accompaniment. 24, 64, 472

Voice alone. 9, 37, 72, 94, 95

Voice with flageolet accompaniment. 64

Voice with flute accompaniment. 54, 64

Voice with guitar accompaniment. 306, 307, 308, 309, 335, 347, 376, 377, 386, 393, 431, $439,460,462,464,465,467,468,469,498,509,510,541$

Voice with harp accompaniment. 31, 54, 66, 125, 176, 178, 224, 323, 328, 369, 372, 499 
Voice with harpsichord accompaniment. 26

Voice with instrumental bass accompaniment. 23,41

Voice with piano accompaniment. 1, 4, 5, 7, 8, 10, 11, 12, 13, 14, 15, 16, 17, 18, 21, 24, $25,26,28,29,30,31,34,35,36,38,39,42,43,44,45,46,47,48,49,50,52,53$, $54,55,56,58,59,61,65,66,67,69,70,72,73,74,75,78,81,82,83,85,86$, $89,90,91,92,93,97,100,103,109,111,112,113,115,116,120,121,125$, $128,129,131,132,136,138,139,140,141,146,147,148,149,151,152,153$, $154,155,156,162,164,165,166,167,168,169,172,173,174,175,176,178$, $181,182,183,184,187,188,189,190,191,192,193,194,196,198,199,201$, $204,205,206,207,208,209,210,211,213,214,216,224,225,231,233,236$, $237,238,239,240,242,243,244,245,246,247,251,252,254,255,256,257$, $258,259,260,261,262,264,265,266,267,268,269,270,271,273,274,275$, $277,278,279,281,282,283,284,286,287,289,290,291,293,295,296,297$, $299,300,302,303,310,311,312,313,315,316,318,319,320,323,326,328$, $334,337,338,344,346,352,353,358,359,361,362,364,366,367,368,369$, $370,371,372,373,374,375,378,379,380,381,382,383,384,385,387,389$, $390,391,393,394,395,396,397,399.400,401,402,403,405,406,409,411$, $412,413,414,416,418,419,422,423,433,434,437,438,440,441,442,444$, $445,447,448,450,452,453,454,457,458,461,463,466,470,471,475,476$, $479,480,482,483,484,485,486,487,491,492,493,496,499,500,501,502$, $503,504,505,507,511,514,515,516,517,518,519,520,523,524,525,527$. $528,529,530,531,532,534,535,536,537,542,544,546,547,548,549,550$, 551

Voice with piano and clarinet accompaniment. 318

Voice with piano and guitar accompaniment. 219, 234

Voice with piano and two flutes accompaniment 436 


\section{BIBLIOGRAPHY}

Anthology of Early American Keyboard Music. Edited by J. B. Clark. Recent Researches in American Music, 2. Madison: A-R Editions, 1977.

The Art of Music: American Paintings \& Musical Instruments 1770-1910. Clinton: N.Y.: Fred L. Emerson Gallery, Hamilton College, 1984.

Ayars, Christine Merrick. Contributions to the Art of Music in America by the Music Industries of Boston 1640 to 1936. New York, 1937; reprint ed., New York: Johnson Reprint Co., 1969.

Carr, Benjamin. Selected Secular and Sacred Songs. Edited by E. R. Meyer. Recent Researches in American Music, 15. Madison: A-R Editions, 1986.

Catalogue of the large and valuable stock of music plates, sheet music, musical instruments, material, \&\&c., being the entire stock of the late George E. Blake. Philadelphia: M. Thomas \& Sons, [1871].

Clinkscale, Martha Novak. Makers of the Piano 1700-1820. Oxford: Oxford University Press, 1993.

Cooper, Wendy A. Classical Taste in America 1800-1840. New York: Abbevile Press, 1993.

Crawford, Richard and D. W. Krummel. "Early American Music Printing and Publishing," in Printing and Society in Early America, edited by W. L. Joyce et al. Worcester: American Antiquarian Society, 1983, pp. 186-227.

Davison, Nancy R. "The Grand Triumphal Quick-step; or, Sheet Music Covers in America," in Prints in and of America to 1850. Edited by John D. Morse. Charlottesville: The University Press of Virginia, 1970, pp. 257-94.

Dichter, Harry and Elliot Shapiro. Early American Sheet Music: Its Lure and Its Lore 1768-1889. New York: R. R. Bowker Co., 1941. 
Dow, George Francis. The Arts \& Crafts in New England 1704-1775. Topsfield:

Massachusetts: The Wayside Press, 1927.

Dudgeon, Ralph T. The Keyed Bugle. Metuchen, N. J.: The Scarecrow Press, 1993.

Eliason, Robert E. "Flute Makers of Early America, part I," Woodwind World-Brass \&

Percussion 15, no. 1 (January 1976): 28-29, 49.

"Flute Makers of Early America, part 2," Woodwind World-Brass \&

Percussion 15, no. 2 (March 1976): 24, 26.

. "Letters to Marsh \& Chase from Graves \& Company, Musical Instrument

Makers," Journal of the American Musical Instrument Society 4 (1978): 43-53.

Farrar, Lloyd. "A Directory of American Wind Instrument Makers." Unpublished MS, 1991.

Fisher, William Arms. Notes on Music in Old Boston. Boston: Oliver Ditson Company, 1918.

One Hundred and Fifty Years of Music Publishing in the United States: An

Historical Sketch with Special Reference to the Pioneer Publisher, Oliver Ditson

Company, Inc. 1783-1933. Boston: Oliver Ditson Co., 1933; reprint ed., Clair

Shores, Mich.: Scholarly Press, 1977.

George Bickham Colouring Book, The. New York: Performers Editions, n.d.

Gottesman, Rita S. The Arts and Crafts in New York 1726-1776. New York: New York

Historical Society, 1936; reprint ed., New York: Da Capo, 1970.

Groce, Nancy. Musical Instrument Makers of New York: A Directory of Eighteenth- and

Nineteenth-Century Urban Craftsmen. Annotated Reference Tools in Music, 4.

Stuyvesant, N.Y.: Pendragon Press, 1991.

Guide for Dating Early Published Music: A Manual of Bibliographical Practices. Edited by Donald W. Krummel. Hackensack, N.J.: J. Boonin, 1974. 
Harding, Rosamond E. M. The Metronome and It's [sic] Precursors. London, 1938; reprint ed., Henley-on-Thames: Gresham Books, 1983.

Hewitt, James. Selected Compositions. Edited by J. W. Wagner. Recent Researches in American Music, 7. Madison: A-R Editions, 1980.

Hitchings, Sinclair. "The Musical Pursuits of William Price and Thomas Johnston," in Music in Colonial Massachusetts 1630-1820, edited by B. Lambert. II. Music in Homes and in Churches; Boston: The Colonial Society of Massachusetts, 1985, pp. 631-54.

Hoover, Cynthia Adams. "Epilogue to Secular Music in Early Massachusetts," in Music in Colonial Massachusetts 1630-1820, edited by B. Lambert. II: Music in Homes and in Churches; Boston: The Colonial Society of Massachusetts, 1985, pp. 715867.

Hunt, Edgar. The Recorder and Its Music. Rev. ed. London: Eulenberg Books, 1977. Johnson, H. Earle. "The John Rowe Parker Letters," Musical Quarterly 42 (January 1976): 72-86. Music Interludes in Boston 1795-1830. New York: Columbia University Press, 1943.

Krummel, Donald W. English Music Printing 1553-1700. London: The Bibliographical Society, 1975. . "Graphic Analysis-Its Application to Early American Engraved Music," Music Library Association Notes, 16, no. 2 (March 1959): 213-33. . "Philadelphia Music Engraving and Publishing, 1800-1820: A Study in Bibliography and Cultural History." Ph.D. diss., The University of Michigan, 1958. 
. "Supplement to the Guide for Dating Early Published Music," Fontis Artis Musicae 24 (1977): 175-84.

Kuronen, Darcy. "The Musical Instruments of Benjamin Crehore," Journal of the Museum of Fine Arts, Boston 4 (1992): 52-79.

Lambert, Barbara. "Social Music in Colonial Boston," in Music in Colonial Massachusetts 1630-1820, edited by B. Lambert. II: Music in Homes and in Churches; Boston: The Colonial Society of Massachusetts, 1985, pp. 409-514. . "Appendix C: Music Masters in Colonial Boston," in Music in Colonial Massachusetts 1630-1820, edited by B. Lambert. II: Music in Homes and in Churches; Boston: The Colonial Society of Massachusetts, 1985, pp. 935-1157. Langwill, Lyndesay G. An Index of Musical Wind-Instrument Makers, 6 th ed. Edinburgh: The Author, 1980.

Leppert, Richard. Music and Image: Domesticity, Ideology and Socio-Cultural Formation in Eighteenth-Century England. Cambridge: Cambridge University Press, 1988.

Libin, Laurence. American Musical Instruments in the Metropolitan Museum of Art. New York: W. W. Norton \& Co.; 1985. . "19th-century keyboards suffer in New Jersey," Newsletter of the American Musical Instrument Society XXII, no. 1 (February 1993): 1, 4-6.

Loesser, Arthur. Men, Women and Pianos: A Social History. New York: Simon and Schuster, 1954.

Lowens, Irving. A Bibliography of Songsters Printed in America Before 1821. Worcester: American Antiquarian Society, 1976.

Marcuse, Sibyl. Musical Instruments: A Comprehensive Dictionary. New York: Doubleday \& Co., 1964. 
Music Printing and Publishing, edited by Donald W. Krummel and Stanley Sadie. The Norton/Grove Handbooks in Music. New York: W. W. Norton, 1990.

The Newberry Library Catalog of Early American Printed Sheet Music. Edited by Bernard E. Wilson. 3 vols. Boston: G. K. Hall \& Co., 1983.

The New Grove Dictionary of American Music, edited by S. Sadie and H. Wiley Hitchcock. 3 vols. New York: Macmillan, 1986.

Odell, George. Annals of the New York Stage. 15 vols. New York: Columbia University Press, 1927-1949.

Pressley, Nancy Gamble. "Winterthur Museum's Early American Keyboard and Music Collection: An Example of Museum Resources for Music in Higher Education" Ph.D. diss., Southern Illinois University at Carbondale, 1982.

Redway, Virginia Larkin. Music Directory of New York City. New York: The New York Public Library, 1941.

Sonneck, Oscar George Theodore. A Bibliography of Early Secular American Music [18th Century], rev. ed. by W. T. Upton. Washington, D.C.: The Library of Congress, 1945.

Spillane, Daniel. History of the American Pianoforte: Its Technical Development, and the Trade. New York: The Author; reprint ed., New York: Da Capo, 1969.

Taricani, Jo Ann. "Music in Colonial Philadelphia: Some New Documents," Musical Quarterly 65 (April 1979): 185-99.

Tawa, Nicholas E. Sweet Songs for Gentle Americans: The Parlor Song in America, 1790-1860. Bowling Green, Ohio: Bowling Green University Popular Press, 1980.

Waterhouse, William. The New Langwill Index: A Dictionary of Musical WindInstrument Makers and Inventors. London: Tony Bingham, 1993. 
Wenberg, Thomas James. The Violin Makers of the United States. Mt. Hood, Ore.: Mt. Hood Publishing Co., 1986.

Weston, Pamela. Clarinet Virtuosi of the Past. London: Robert Hale, 1971.

Wolfe, Richard J. Early American Music Engraving and Printing: A History of Music Publishing in America from 1787 to 1825 with Commentary on Earlier and Later Practices. Urbana: University of Illinois Press, 1980.

- Secular Music in America, 1801-1825; a Bibliography. 3 vols. New York: The New York Public Library, 1964. 